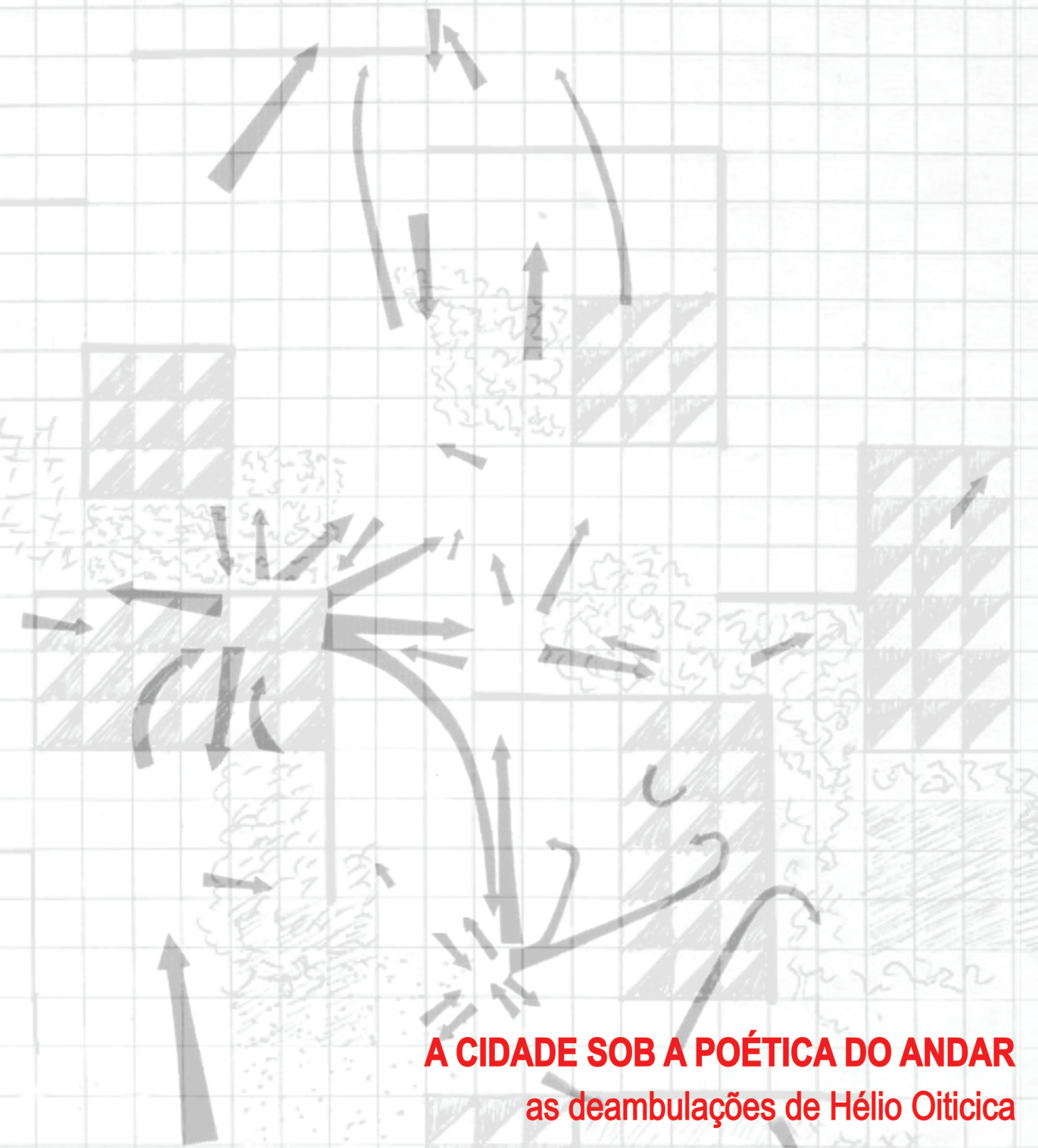

Ana Carolina Fróes Ribeiro Lopes

Orientador Prof. Dr. Carlos R. M. de Andrade 



\title{
A Cidade sob a Poética do Andar As Deambulações de Hélio Oiticica
}

\author{
Ana Carolina Fróes Ribeiro Lopes \\ Orientador: Prof. Dr. Carlos Roberto Monteiro de Andrade
}

Tese de doutorado apresentada ao Instituto de Arquitetura e Urbanismo - IAU-USP, como parte dos requisitos para obtenção do título de Doutor em Teoria e História da Arquitetura e Urbanismo.

USP - São Carlos 
AUTORIZO A REPRODUÇÃO TOTAL OU PARCIAL DESTE TRABALHO, POR QUALQUER MEIO CONVENCIONAL OU ELETRÔNICO, PARA FINS DE ESTUDO E PESQUISA, DESDE QUE CITADA A FONTE.

Fróes Ribeiro Lopes, Ana Carolina

A Cidade sob a Poética do Andar: as Deambulações de Hélio Oiticica / Ana Carolina Fróes Ribeiro Lopes; orientador Prof. Dr. Carlos Roberto Monteiro de Andrade. São Carlos, 2012.

Tese (Doutorado) - Programa de Pós-Graduação em Arquitetura e Urbanismo e Área de Concentração em Teoria e História da Arquitetura e do Urbanismo -Instituto de Arquitetura e Urbanismo da Universidade de São Paulo, 2012.

1. Hélio Oiticica, Situacionistas, Situação, Urbanismo Unitário, Labirinto. I. Título. 


\section{FOLHA DE JULGAMENTO}

Candidata: Arquiteto Urbanista ANA CAROLINA FRÓES RIBEIRO LOPES

Título da tese: "A Cidade sob a Poética do Andar: as Deambulações de Hélio Oiticica"

Data da defesa: 25/02/2013

Comissão Julgadora:

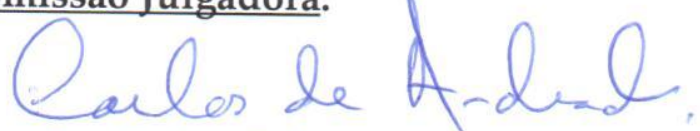

Prof. Dr. Carlos Roberto Monteiro de Andrade (Orientador)

(Instituto de Arquitetura e Urbanismo/USP)

Resultado:

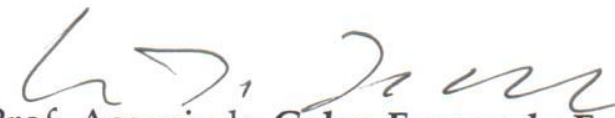

Prof. Associado Celso Fernando Favaretto

(Faculdade de Educação/USP)
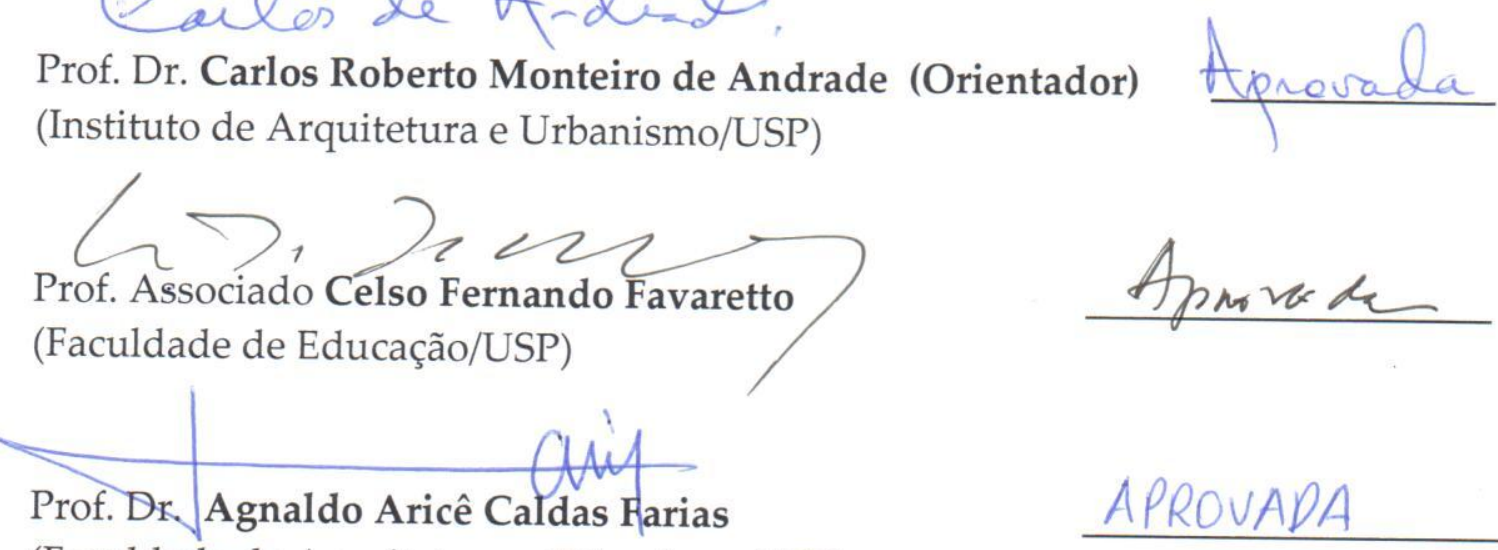

(Faculdade de Arquitetura e Urbanismo/USP)
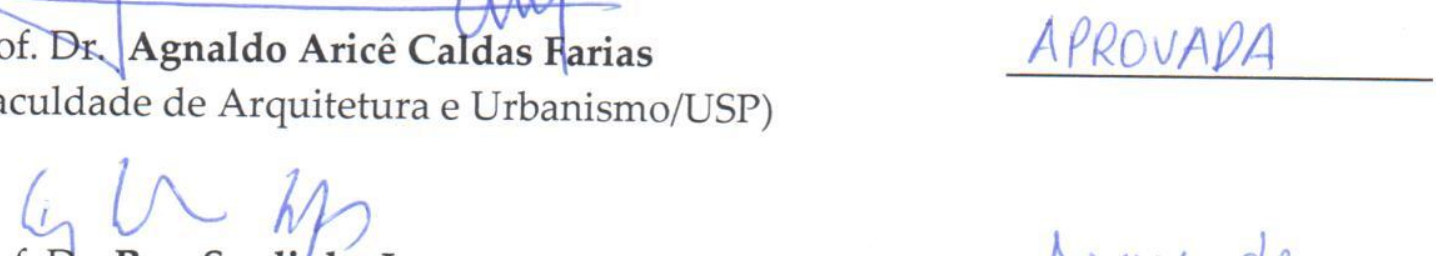

Prof. Dr. Ruy Sardinha Lopes

(Instituto de Arquitetura e Urbanismo/USP)
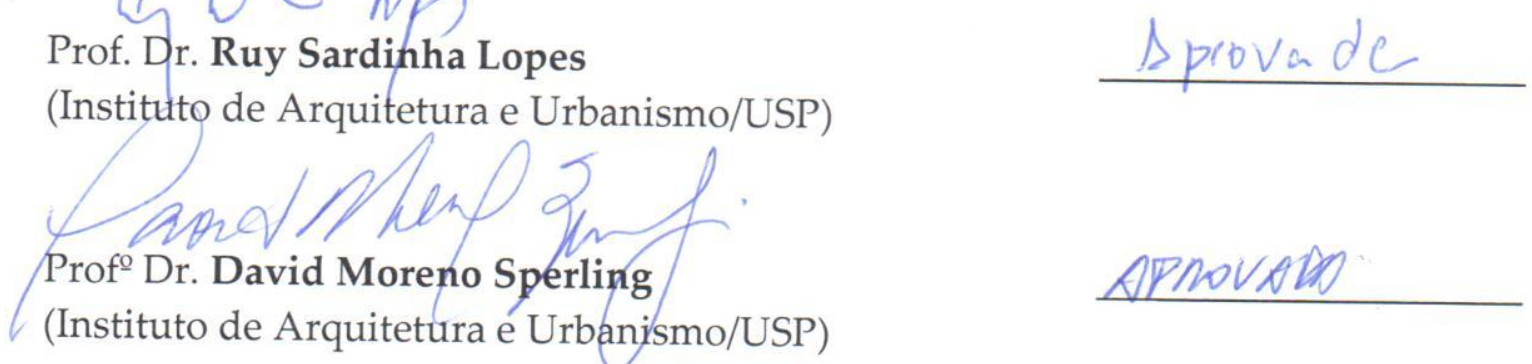

\section{APNOVODO}

Coordenador e Presidente da Comissão de Pós-Graduação: do Programa de PósGraduação em Arquitetura e Urbanismo: Prof. Titular Renato Luiz Sobral Anelli 
Ao Alneu e ao nosso filho Heitor 

"A cidade é toda ela a casa do homem."

Flávio de Carvalho 



\section{Agradecimentos}

Tenho a impressão que este agradecimento foi sendo escrito aos poucos, trabalhado mentalmente, quando mesmo depois de um dia exaustivo, ainda me felicitava com um sentimento verdadeiro de agradecimento. Este exercício em agradecer é fundamental para nos dar conta que no meio de um trabalho tão solitário como o da pesquisa e da escrita da tese, nada seria possível se não fosse a disponibilidade e a gentileza de alguns e o espírito acadêmico e generoso de outros. Nesta pequena grande lista inicio agradecendo ao Prof. Dr. Carlos Roberto Monteiro de Andrade (o Mancha), meu orientador, pelo entusiasmo e exemplo de dedicação à pesquisa, me felicitando ainda com a convivência com um grupo inestimável de pesquisadores, o Grupo URBIS. Ao Mancha, por quem eu só cultivei, em todos esses anos, admiração e respeito, meu sincero agradecimento.

Ao grupo URBIS, agradeço especialmente a oportunidade em participar de debates de alto nível. Minha admiração aos pesquisadores George Dantas, Renata Cabral, Camila Corsi, Maristela Janjulio, Thais Cruz, Alessandra Pavesi, Lucas Cestaro e aos Profs. Drs. Givaldo Medeiros e Luciana Shenk. Ao Rodrigo Nogueira Lima agradeço pela oportunidade da interlocução, na discussão sobre o tema da pesquisa, ao Prof. Dr. Francisco Sales Trajano, pelas referências bibliográficas, comentários e generosas sugestões para esta pesquisa.

Agradeço à CAPES pelo apoio financeiro.

Agradeço ao Projeto Hélio Oiticica, especialmente, a Ariane Figueiredo, que sempre colocou-se gentilmente à disposição, e disponibilizou para essa pesquisa o Catalogue Raisonné de HO.

Nesta caminhada, na qual acabei incorporando em grande parte o próprio espírito da deambulação, uma vez que tinha um verdadeiro labirinto documental a trilhar, também fui surpreendida com felizes 'encontros' que contribuíram para uma particular abordagem dos objetos desta pesquisa. Agradeço ao filósofo italiano Mário Perniola, talvez um dos últimos situacionistas vivo, que gentilmente respondeu meus emails e nos recebeu em São Paulo, concedendo uma entrevista, quando em visita ao Brasil. Agradeço ao Luis Fernando Guimarães, o Lfer, que nos recebeu em sua casa e 
generosamente compartilhou suas lembranças do amigo Hélio Oiticica. Ao Michael Chapman, que por uma obra do destino, sempre esteve mais próximo do que poderíamos imaginar, o poeta performático, que integrou o Exploding Galaxy, que vive e leciona no Rio Grande do Sul, meus sinceros agradecimentos por sua gentil disponibilidade e atenção ao responder a nossa entrevista, contribuindo significativamente com a investigação. Ainda agradeço ao artista Ivald Granato, ao Prof. Dr. Emiliano Fortaleza de Aquino e ao Prof. Dr. Dante Augusto Galeffi, pelo envio de material.

Agradeço ao Prof. Dr. Celso Favaretto e ao Prof. Dr. David Sperling que integraram minha banca de Exame de Qualificação, contribuindo com sugestões e críticas que auxiliaram o desenvolvimento e a finalização desta investigação.

Agradeço ainda as colegas italianas Lorenza Pavezi e Luisa Videsotti que me ajudaram revisando o meu texto em italiano para as trocas de emails. As irmãs Marieli e Juliana Lukiantchuki, Rodrigo Jabur, Vanessa Rosa, pelos encontros sempre divertidos. A Sara Grubert que mesmo distante colaborou com importantes contatos, e por quem ainda carrego na lembrança bons momentos do mestrado. A Amanda Ruggiero pela amizade e paciência em me ouvir já no final da escrita da tese, possibilitando ricas conversas sobre o tema da pesquisa. Agradeço a Lucilene, a Lú, com quem também pude contar com a torcida sempre positiva, a amizade e a colaboração nos momentos mais difíceis.

No âmbito da família agradeço a torcida carinhosa da minha irmã Mary Carmem, a Mel, e a minha irmã Ana Carla. Aos meus queridos pais, José Carlos Gomez Ribeiro e Cândida Rodrigues Froés Ribeiro que me conduziram na caminhada da vida. Ao Alneu e ao Heitor que fazem desta caminhada um desafio e um prazer. 


\section{Resumo}

Esta tese investiga proximidades entre as proposições de Hélio Oiticica e conceitos como 'construção de situação', 'deriva' e 'urbanismo unitário' desenvolvidos pela Internacional Situacionista - IS (1957-1972). Além da literatura da área, foram explorados dois corpus documental, os Boletins da Internacional Situacionista e o Catalogue Raisonné de Hélio Oiticica. A partir dos Boletins foi possível compreender a formulação dos principais conceitos situacionistas, enquanto o Catalogue Raisonné de Hélio Oiticica possibilitou reconstituir suas deambulações urbanas. Suas caminhadas pela cidade refletem sua crítica à cidade e aos modos de vida urbano. Este caráter crítico está presente no desenvolvimento de seu Programa Ambiental, onde suas proposições estéticas buscam reestabelecer, justamente, as relações entre o indivíduo e a cidade. Os arquivos consultados, manuscritos, cartas, entrevistas, e um grande número de documentos inéditos foram fundamentais para a reconstrução de seus 'passos' e o entendimento, a partir de seu próprio discurso, de suas relações com a crítica social e urbana desenvolvida pelos situacionistas.

Palavras-Chave: Hélio Oiticica, Deambulação, Sociedade do Espetáculo, Construção de Situação, Urbanismo Unitário, Labirinto. 



\section{Abstract}

This thesis investigates proximities between propositions of Hélio Oiticica and concepts such as 'situation', 'dérive' and 'unitary urbanism' developed by the Situationist International - IS (1957-1972). Besides the literature of the field, two documentary corpus were explored, the Bulletins of the Situationist International and Catalogue Raisonné of Hélio Oiticica. From the Bulletins it was possible to understand fundamental Situationist concepts, while the Catalogue Raisonné of Hélio Oiticica allowed to reconstitute its urban wanderings. His strolls reflect his criticism to the city and urban lifestyles. This criticality is present in the developing of his Environmental Program, where his aesthetic propositions seek to reestablish precisely the relationship between the individual and the city. The archives consulted, manuscripts, letters, interviews, and a large number of unpublished documents were key elements to rebuilding his 'steps' and the understanding, based on his own speech, of the relationship between Oiticica and social and urban critics developed by the Situationists.

Keywords: Hélio Oiticica, Dérive, Society of the Spectacle, Construction of Situation, Unitary Urbanism, Labyrinth. 



\section{Sumário}

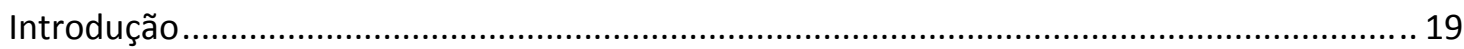

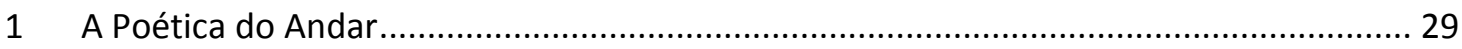

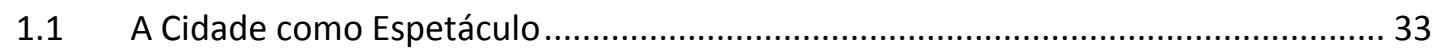

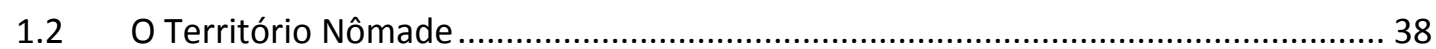

1.3 O Andar como Experiência Estética ............................................................................ 44

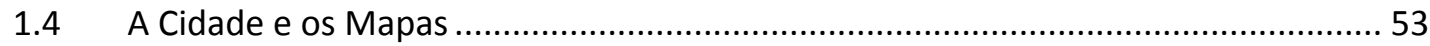

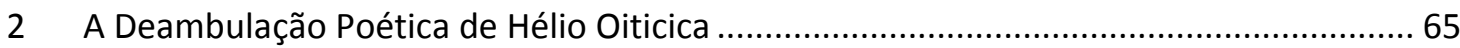

2.1 A Deambulação de HO em Londres ........................................................................ 79

2.2 A Deambulação de HO em Nova lorque .................................................................... 95

$2.3 \quad$ O Delirium (De)Ambulatorium ....................................................................... 121

3 O Labirinto na Poética do Espaço................................................................................ 133

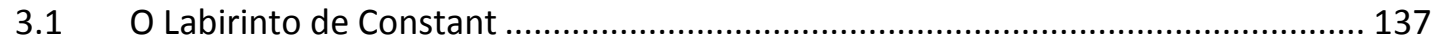

3.2 O Labirinto de Hélio Oiticica ............................................................................... 143

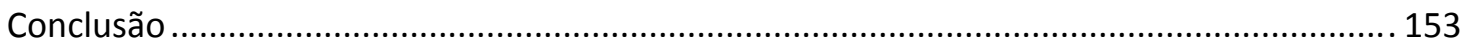

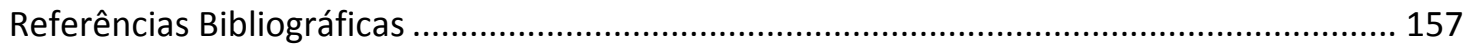





\section{Lista de Figuras}

Figura 1 Carte du Pays de Tendre, Madeleine Scudére. in http://upload.wikimedia.org/wikipedia/commons/6/6b/Carte_du_tendre_300dpi.jpg ......... 54

Figura 2 Discours Sur Les Passiones de L'Amour. Guy Debord, 1957..................................... 58

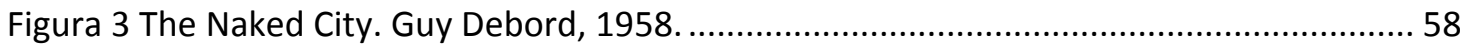

Figura 4 Paris et l'agglomération parisienne, Paul-Henry Chombart de Lauwe, 1952 ............. 59

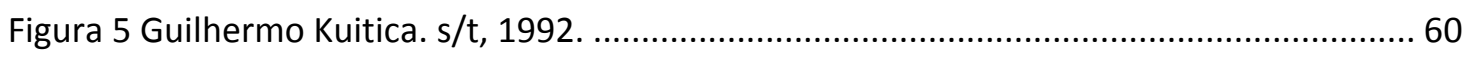

Figura 6 Sol LeWitt, Photograph of Part of Manhattan with the Area Between the John Weber Gallery, the Former Dwan Gallery, and Sol LeWitt's Residence de 1977. 62

Figura 7 Waltercio Caldas. Japão, 1972. 63

Figura 8 O Parangolé no MAM, 1965. Catalogue Raisonné n. doc. 2016.65 69

Figura 9 Bólide Caixa 18 Homenagem a Cara de Cavalo, 1966. in Catalogue Raisonné n. doc. 71 Figura 10 Imagens do evento Apocalipopótese. in Catalogue Raisonné, n. doc. 2139.68....... 73

Figura 11 David Medalla, Cloud Canyons (Bubble Muchine), Londres, 1964.

http://www.1fmediaproject.net/2011/05/19/david-medalla-cloud-canyon-n-14-19632011new-museum-n-y/ (acessado em 19/09/2012) .....

Figura 12 David Medalla, Cloud Canyons (Bubble Muchine), Londres, 1964.

http://entretenimento.uol.com.br/album/clay_perry_sp_album.htm (acessado em 19/09/ 2012)

Figura 13 David Medalla, Cloud Canyons, Londres, 1964.

http://entretenimento.uol.com.br/album/clay_perry_sp_album.htm (acessado em 19/09/ 2012)

Figura 14 Mário Pedrosa e Hélio Oiticica colhendo detritos nas ruas de Londres, final dos anos 1960. Arquivo Michael Chapman.

Figura 15 Nota no verso do texto Crelazer de Hélio Oiticica, Londres, 14 de janeiro de 1969.

Catalogue Raisonné n. doc. 0367.69. 91 
Figura 16 Hélio Oiticica num Ninho (Babylonests) em seu apartamento em Nova lorque, 1971. .96

Figura 17 Ninhos (Babylonests) no apartamento de Hélio em Nova lorque, 1971. ................. 97

Figura 18 Localização Google Maps: A. 2a. Avenida, n. 81 e B. Greene Street, n. 112 ............. 98

Figura 19 Figura 19 Localização Google Maps. A. Loft de Hélio e B. Loft de Matta-Clark. ..... 100

Figura 20 Cartão Postal de Gordon Matta-Clark a Hélio Oiticica. Catalogue Raisoneé n. doc. 2520.72 101

Figura 21 Open House. Greene Street, New York, 1972. in Gordon Matta-Clark ................... 104

Figura 22 Planta do PN16-NADA. Catalogue Raisoneé n. doc. 0414.71 .................................. 106

Figura 23 Figura 22 Instruções para Evento "E PET C LO" na Universidade de São Paulo.

Catalogue Raisoneé n. doc. 0205.72 (Folha 1) 110

Figura 24 Instruções para Evento "E PET C LO" na Universidade de São Paulo. Catalogue Raisoneé n. doc. 0205.72 (Folha 2)

Figura 25 Event E PET C LO de HO desenvolvido na ECA-USP, 2009.

Figura 26 Ivald Granato entre Hector Babenco e Raquel Arnauld em Mitos Vadios. Acervo Ivald Granato

Figura 27 Hélio Oiticica em Mitos Vadios, 1978. Acervo Ivald Granato. 124

Figura 28 Hélio Oiticica em Mitos Vadios. in Catalogue Raisonné n. doc. 2244.78 ................ 125

Figura 29 Participação de Lygia Pape em Mitos Vadios. in Acervo Ivald Granato. ................... 126

Figura 30 representação espacial de um labirinto clássico................................................... 135

Figura 31 Constant. Maquete para um acampamento de ciganos, 1958. 138

Figura 32 Constant. Litografia. Nova Babilônia, 1963. Costa, Xavier; Andreotti, Líbero. (organizadores). Situacionistas. Arte, política, urbanismo. Situationist. Arts, politics, urbanismo. Catálogo de exposição. Museu d'Art Contemporani de Barcelona, 1996. p. 148149.

Figura 33 Constant. Setor Amarelo 2, 1958. 141

Figura 34 Constant, Grande Setor Amarelo 4. 141

Figura 35 Constant, Labyrism, Litografias e Aquarelas. 1969. 142

Figura 36 Hélio Oiticica. Relevos Espaciais e Parangolé. in Catalogue Raisonné n. doc. 2467.00. 
Figura 37 Hélio Oiticica. Relevos Espaciais. Exposição Galeria G4, 1966. in Catalogue Raisonné,

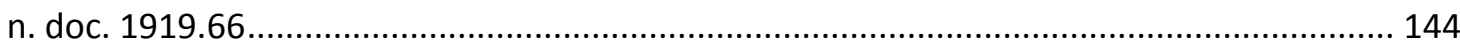

Figura 38 Hélio Oiticica. Núcleos, 1960. in Catalogue Raisonné n. doc. 2171/sd................... 144

Figura 39 Hélio Oiticica. Projeto Cães de Caça, 1961. Acervo Projeto Hélio Oiticica. ............. 145

Figura 40 Hélio Oiticica. Tropicália. Acervo Projeto Hélio Oiticica............................................ 146

Figura 41 Hélio Oiticica. Estudos para o Éden. in Catalogue Raisonné n. doc. 1736.67......... 147

Figura 42 Hélio Oiticica. Éden. Acervo Projeto Hélio Oiticica. ................................................ 147

Figura 43 Hélio Oiticica. Ninhos. Acervo Projeto Hélio Oiticica. .............................................. 148

Figura 44 Hélio Oiticica. PN15, maquete projeto para Penetrável Auto-Teatro, NY, 1971. in

Favaretto, Celso. A Invenção de Hélio Oiticica, p. 209. ............................................................ 149

Figura 45 Hélio Oiticica. Subterrânea, maquete projeto 1, Tropicália. Nova lorque, 1971.

Acervo Projeto Hélio Oiticica

Figura 46 Hélio Oiticica. Magic Square n5 - De Luxe. imagem:

http://www.inhotim.org.br/uploads/Obras/5f61cbc3b546e8007d601292a184f846_media.jpg 



\section{Introdução}

Hélio Oiticica certa vez escreveu que assumiu o experimental a partir de 1959, quando rompeu com a representação euclidiana e, consequentemente, com o modo contemplativo de apreensão do objeto artístico ${ }^{1}$. Esta tomada de posição distancia-o do conceito de artista como 'criador de obras', para aproximá-lo do que Mário Pedrosa chamou de exercício experimental da liberdade ${ }^{2}$, que não tem fronteiras, uma vez que o experimental é a "metacrítica da 'produção de arte"'3. Hélio assumiu sua posição experimental com o 'desenvolvimento nuclear da cor' num processo de estruturação da cor no espaço, onde articulou, paulatinamente, o campo da pintura ao da arquitetura e urbanismo, numa correspondência aos desígnios construtivistas presentes no início do século $\mathrm{XX}^{4}$.

Hélio rompeu com a linearidade a partir de estruturas dinâmicas e labirínticas, que se realizam em sua totalidade a partir da 'experimentação' e da 'vivência' desses espaços. Seus Penetráveis condensam, ao mesmo tempo, o 'desenvolvimento nuclear da cor', a partir da tridimensionalidade do plano pictórico, e a crítica aos processos

\footnotetext{
1 Hélio Oiticica integrou o Grupo Frente entre 1955 a 1956, e posteriormente, o Grupo Neoconcreto em 1959. Segundo Ronaldo Brito, o neoconcretismo representou a um só tempo o vértice da consciência construtiva no Brasil e a sua explosão. A experiência neoconcreta revela um alinhamento às teorias da percepção de Merleau-Ponty e de La structure du comportement de Suzanne Langer, bem como, os conceitos de expressão e de organicidade. Brito, R. Neoconcretismo: vértice e ruptura do projeto construtivo brasileiro. São Paulo: Cosac \& Naify, 1999. p. 55, 73 e 75.

2 expressão utilizada pelo crítico de arte Mário Pedrosa para definir o desenvolvimento artístico de Hélio Oiticica.

3 Oiticica, Hélio. Experimentar o experimental. Nova Iorque, 22 de março de 1972. in Catalogue Raisonné n. doc. 0380.72.

4 Frase de Piet Mondrian que Hélio cita em seu diário em 1959: "what is certain, is that there is no escape for non-figurative artist; he must stay within his field and march towards the consequence of his art. this consequence brings us, in a future perhaps remote, towards the end of art as a thing separate of our surrounding environment, which is the same time a new beginning. Art will not only continue but will realize itself more and more. By the unification of architecture, sculpture and painting a new plastic reality will be created. Painting and sculpture will not manifest themselves as separate objects, nor as "mural art" or "applied art", but being purely constructive, will aid the creation of a surrounding not merely utilitarian or rational, but also pure and complete in its beauty". "O que é certo é que não há saída para o artista não-figurativo, ele deve permanecer dentro de seu campo e caminhar em direção à consequência de sua arte. Esta consequência nos leva num futuro talvez remoto, em direção ao fim da arte como uma coisa separada do nosso meio ambiente, que é ao mesmo tempo um novo começo. A arte não apenas continuará, mas realizar-se-á mais e mais. Pela unificação da arquitetura, escultura e pintura uma realidade plástica nova será criada. A pintura e a escultura não se manifestarão como objetos separados, nem como 'arte mural' ou 'arte aplicada', mas sendo puramente construtivas, ajudarão a criar um ambiente não meramente utilitarista ou racional, mas também puro e completo em sua beleza" (tradução livre da autora). in Catalogue Raisonné n. doc. 0182.59 p. 6.
} 
culturais e artísticos, a partir da proposta de um ambiente que articula a arte e vida. Eles também representam uma resposta às suas deambulações urbanas (seu delirium ambulatorium), o que permite considerá-los também, como 'metacrítica' da cidade real.

A Cidade sob a Poética do Andar: as deambulações de Hélio Oiticica investiga as deambulações empreendidas pelo artista, recolhendo pistas e vestígios que delineiam sua visão de mundo, tanto a partir de suas proposições como de suas críticas à arte e à cidade. A hipótese inicial desta investigação centrou-se na proximidade dessas ações à noção de 'situação', expressão cunhada pela Internacional Situacionista (1957-1972).

O grupo Internacional Situacionista constituiu-se a partir da fusão do Grupo Cobra, com o Movimento Internacional por uma Bauhaus Imaginista e com o Movimento Letrista, reafirmando a tendência ao experimental e à crítica social e política. Essas duas principais tendências, presentes na genealogia da IS, reafirmam a cidade como campo de ação para a transformação da vida cotidiana. Elas criticavam a vida nas cidades modernas, acusando o urbanismo funcionalista e separatista como responsável pela monotonia e alienação dos indivíduos, almejando uma revolução social. Também formularam uma série de atividades que visavam aproximar arte e vida, propondo a construção de momentos de criação coletiva para a transformação da vida cotidiana das pessoas. Desta forma, além da ideia de construção de situações, surgiram um conjunto de novos conceitos como urbanismo unitário, deriva, psicogeografia e sociedade do espetáculo, que constituem o arcabouço teórico ainda relevante como contribuição teórica e crítica ao capitalismo.

A ideia de uma revolução na vida cotidiana foi um dos principais temas desenvolvidos pelo filósofo e sociólogo francês Henri Lefebvre (1901-1991) ${ }^{5}$. O livro a Crítica da Vida Cotidiana, de Lefebvre, foi citado por Christian Dotremont (figura chave do movimento Cobra), na primeira reunião do Grupo Revolucionário Surrealista, em outubro de 1947. Tal grupo antecedeu a formação do Cobra, deixando claro que o experimento surrealista deveria ocorrer no contexto da vida diária ${ }^{6}$. Somam-se às reflexões sobre a vida cotidiana, a crítica à sociedade e ao capitalismo

\footnotetext{
5 Critique de la vie quotidienne foi lançado em 1947, em um primeiro volume. Posteriormente, em 1961, Lefebvre publicou um segundo volume de Critique de la vie quotidienne e em 1991, foi lançado uma versão resumida acrescida de algumas questões novas: La vie quotidienne dans le monde moderne. Este último foi traduzido para o português e lançado no Brasil em 1991.

6 Home, S. Assalto à Cultura: utopia, subversão e guerrilha na (anti) arte do século XX. Tradução Cris Siqueira. São Paulo: Conrad, 2004. p. 22.
} 
moderno, de Guy Debord, sintetizada no livro La Société du Spectacle, de 19677, O princípio característico dessa sociedade, definida por Guy Debord, como a 'sociedade do espetáculo', dá-se na relação entre a alienação e o espetáculo, ou seja, na nãoparticipação, no isolamento.

A busca pela transformação do espectador em participador, bem como, o conjunto de elementos e situações que Hélio Oiticica propõe no sentido de 'participação' do indivíduo, relaciona-se com as propostas situacionistas de combate à 'sociedade do espetáculo'. Observa-se que, enquanto os situacionistas buscam “construir situações” para retirar o sujeito da passividade, Hélio Oiticica também evoca, a partir de suas proposições, experiências descondicionantes que proporcionassem a desalienação do indivíduo. Em suas proposições estão presentes também a contraposição ao espaço cartesiano e funcionalista da cidade e a natureza opressiva e alienante do espaço produzido pelo capitalismo avançado. Hélio formula um ideal urbano que parte da ideia de espaços nômades e lúdicos que se estruturam de forma labiríntica. Tais paralelos culminam no projeto de uma cidade nômade, a Nova Babilônia, do holandês Constant Nieuwenhuys, do lado dos situacionistas e, em Hélio Oiticica, nas formulações de Crelazer (lazer criador 8 ), Éden (um campus experimental, uma espécie de taba, onde todas as experiências humanas são permitidas $^{9}$ ), e na ideia-projeto Barracão (ambiente total comunitário do Crelazer) ${ }^{10}$.

As atividades experimentais realizadas pelos situacionistas, a crítica social e política e o caráter subversivo de suas ações remetem às vanguardas do início do século XX, os dadaístas e os surrealistas. Um ponto de tangência dessas vanguardas, além de visarem a integração da arte com a vida e de todas as atividades humanas, criticando a separação social e acreditando no conceito de totalidade ${ }^{11}$, se expressa no fato de todas terem utilizado a cidade como campo de investigação estética, adotando a prática “deambulatória” pela cidade como crítica social e urbana, como apontou Francesco Careri em seu livro Walkscapes ${ }^{12}$. Guy Debord, antes mesmo da formação

7 Debord, G-E. A Sociedade do Espetáculo. Tradução Estela dos Santos Abreu. Rio de Janeiro: Contraponto, 1997.

8 Oiticica, Hélio. As possibilidades do Crelazer. Paris, 10 de maio de 1969. In Catalogue Raisonné, $\mathrm{n}^{\circ}$ doc. 0305.69 p.1-2.

9 Catálogo da Exposição na Whitechapel Gallery de Londres. In Catalogue Raisonné, no doc. 2083.69

10 Oiticica, Hélio. Barracão. Londres, 19 de agosto de 1969. In Catalogue Raisonné, nº doc. 0452.69

11 Home, Stwart. Assalto à cultura: Utopia, subversão e guerrilha na (anti) arte do século XX.

12 Careri, Francesco. Walkscapes: el andar como pratica estética. Barcelona: Gustavo Gili, 2002. 
da IS, quando ainda integrava a Internacional Letrista, formulou em 1956, a Teoria da Deriva, onde o conceito de deriva aparece "indissoluvelmente ligado ao reconhecimento dos efeitos de natureza psicogeográfica e à afirmação de um comportamento lúdico-construtivo"13.

O pesquisador Peter Wollen, em The Situationist International, afirma que o projeto da Internacional Situacionista propunha relançar o movimento surrealista em novas bases, ou seja, despojando-o de alguns elementos, como por exemplo, a ênfase no inconsciente, quase místico e ocultista, e do culto ao irracionalismo ${ }^{14}$. Já a deriva situacionista é definida como um "modo de comportamento experimental ligado às condições da sociedade urbana” 15 .

Hélio Oiticica, por seu turno, propôs experiências improvisadas de caminhar pela cidade, colocando-se em total disponibilidade aos imprevistos do perambular pelas ruas e morros cariocas, chamando a atenção para a importância de se redescobrir o próprio espaço da cidade. Seu comportamento experimental caracterizado por um “deambular crítico-criativo"16, aproxima-se sobremaneira da deriva situacionista, sobretudo, por representar a consciência da importância da “apropriação” do espaço e do tempo para uma redefinição urbana e social ${ }^{17}$. Em seu delirium ambulatorium o campo urbano aparece como um labirinto topográfico, que Hélio materializa a partir de seus Penetráveis, numa resposta à cidade formal e à apreensão psicogeográfica da cidade real.

Assim como os Penetráveis labirínticos de Hélio estão relacionados à sua deambulação urbana, a Nova Babilônia de Constant, representa o projeto que mais se dedicou a investigar as possibilidades espaciais e existenciais da deriva ${ }^{18}$, além de ir

13 Debord, Guy Ernest. Teoria da Deriva. In Jacques, P. B. (organização), Apologia da Deriva: Escritos situacionistas sobre a cidade/Internacional Situacionista. Tradução de Estela dos Santos Abreu. Rio de Janeiro: Casa da Palavra, 2003. p. 87.

14 Wollen, Peter. The Stituationist International. Revista New Left Review, n 174, 1989.

15 Internacional Situacionista. Definições. In Jacques, P. B. (organização), Apologia da Deriva: Escritos situacionistas sobre a cidade/Internacional Situacionista. Tradução de Estela dos Santos Abreu. Rio de Janeiro: Casa da Palavra, 2003. p. 65.

16 Morais. Frederico. Pequeno roteiro cronológico das invenções de Hélio Oiticica. In: Catalogue Raisonné $\mathrm{n}^{\circ}$ doc. 2471.sd.

17 Ideia desenvolvida por Henri Lefebvre em A Crítica a Vida Cotidiana. Neste trabalho, utiliza-se a versão brasileira: Lefebvre. H. A vida cotidiana no mundo moderno. Tradução de Alcides João de Barros. São Paulo: Editora Ática, 1991.

18 Levin, T. Y. Geopolítica de la hibernación: la deriva del urbanismo situacionista. In: Andreotti, L. e Costa, X. (organizadores). Situacionistas: arte, política, urbanismo. Situationists: art, politics, urbanismo. Barcelona: ACTAR, 1996. 
ao encontro da crença situacionista de que a cidade, a partir de sua ambiência, poderia proporcionar a mudança comportamental dos indivíduos, o "despertar ilimitado das paixões”. A IS manteve essa crença pelo menos até 1962, quando toda a ala artística, incluindo Constant, foi desligada do grupo que passou a enxergar na revolução proletária o único caminho para uma revolução social: “todo mundo sabe que no princípio os situacionistas pretendiam, no mínimo, construir cidades, o entorno apropriado para o despertar ilimitado de novas paixões. Porém, como isso evidentemente não era fácil, nos vimos forçados a fazer muito mais”19.

\section{O Ponto de Partida}

A pesquisa teve como ponto de partida a leitura de uma lista bibliográfica relacionada a trajetória de Hélio Oiticica e da Internacional Situacionista. Para a compreensão das principais ideias difundidas pela IS, cumpriu-se, principalmente, o estudo sistemático de seus Boletins ${ }^{20}$, bem como, a leitura da obra La société $d u$ Spectacle de Guy Debord. Pode-se dizer que o interesse dos situacionistas pela cidade, presente na prática da Deriva, na ideia de criação de 'situação' e no conceito de Urbanismo Unitário, ocasionou num recorte no extenso material que a IS apresenta, incluindo o projeto da cidade nômade, a New Babylon de Constant. No caso da trajetória de Hélio Oiticica destacam-se algumas publicações nacionais, como $A$ Invenção de Hélio Oiticica, de Celso Favaretto, publicada em 2000, Estética da Ginga: a arquitetura das favelas através da obra de Hélio Oiticica, de Paola Berenstein Jacques, de 2003 e Fios Soltos: a arte de Hélio Oiticica, uma coletânea de textos de diversos pesquisadores, organizada por Paula Braga e publicado em 2008. Além de teses e de uma série de artigos em periódicos nacionais e estrangeiros.

Estas leituras foram fundamentais para o entendimento do desenvolvimento do Programa Ambiental de Hélio Oiticica, o que resultou na formulação da hipótese desta tese. Destaca-se, porém, que alguns destes trabalhos citam Hélio Oiticica como leitor

19 Debord. Guy Ernest. A Arquitetura Selvagem. Prefácio a Gribaudo, E.; Sala, A Jorn. Le Jardin d'Albisola, 1972. op. cit. Velloso, R. de C. L. Cotidiano Selvagem. Arquitetura na Internationale Situationniste. Arquitextos, Revista Vitruvius. 027.02, ano 3, agosto de 2002.

20 AA.VV. Internazionale Situazionista 1958-1969. (Prefácio de Mario Lippolis). Torino: Nautilus, 1994. 
de Guy Debord, como por exemplo, em Hélio Oiticica: o mapa do programa ambiental $^{21}$, de 2003, tese de doutoramento de Zizette Lagnado Dwek, Estética da Ginga, de 2003, de Paola B. Jacques, A Trama da Terra que Treme: Multiplicidade em Hélio Oiticica ${ }^{22}$, 2007, tese de doutoramento de Paula Priscila Braga. No artigo Elogio aos errantes. Breve histórico das errâncias urbanas, de Paola B. Jacques, publicado em 2004, além de destacar a referência à Sociedade do Espetáculo de Guy Debord nos escritos de Hélio, Paola aponta o delirium ambulatorium em um breve histórico das errâncias urbanas, o que inclui a deriva situacionista.

Esses trabalhos assinalam para uma expansão do contexto filosófico do trabalho de Hélio Oiticica, que permaneceu por muito tempo restrito aos estudos que enfatizavam o envolvimento do artista com a Mangueira, com o samba, e com a arquitetura, o ambiente e a cultura da favela ${ }^{23}$. Atualmente, novas análises sobre seu discurso crítico e novas conexões desse discurso com os debates socioculturais contemporâneos estão sendo viabilizados a partir do exame de seus arquivos: primeiramente, surgiu o projeto do Itaú Cultural, que disponibiliza parcialmente os arquivos em meio digital online. Posteriormente, numa parceria do Projeto Hélio Oiticica com o Museum of fine Arts Houston surgiu o projeto do Catalogue Raisonné de HO, num esforço para uma catalogação completa de sua obra.

A Cidade sob a Poética do Andar: as Deambulações de Hélio Oiticica, explora e analisa documentos ainda inéditos, a partir do Catalogue Raisonné disponibilizado para esta pesquisa pelo Projeto Hélio Oiticica, material fundamental para as análises realizadas neste trabalho.

\footnotetext{
21 Dwek, Zizette Lagnado. Hélio Oiticica: O Mapa do Programa Ambienta. Tese de doutoramento. São Paulo: Dep. de Filosofia, FFLCH-USP, 2003.

22 Braga, Paula Priscila. A Trama da Terra que Treme: Multiplicidade em Hélio Oiticica. Tese de doutoramento. São Paulo: Dep. de Filosofia, FFLCH-USP, 2007.

23 Asbury, Michael. O Hélio não tinha Ginga. in Braga, Paula (organizadora). P. Fios Soltos: A arte de Hélio Oiticica. São Paulo: Perspectiva, 2008. p. 29.
} 


\section{O Fio de Ariadne}

A tese teve como fio condutor dois corpus documentais, os Boletins da IS, publicados entre 1958 e 1969 e o Catalogue Raisonné de Hélio Oiticica. Apesar da diretriz dada por essa documentação e pela bibliografia relacionada, a pesquisa seguiu um método de pesquisa próprio, principalmente, pelo volume e pela diversidade de temas reunidos no Catalogue que ainda configura-se como um material em grande parte inexplorado.

O Catalogue Raisonné de HO reúne cerca de 2.432 documentos digitalizados, contém grande parte, senão tudo, do que constitui a produção de Hélio Oiticica entre os anos de 1950 a 2004. O conjunto desse material encontra-se organizado por Tipo (agenda, bloco, cartão postal, recorte de jornal, folha datilografada, manuscrita e etc.), Série (Acontecimentos Poético Urbanos, Magic Square, Penetrável, Ninhos, QuasiCinema e etc.), Espécie (Artigo, Carta Circular, Correspondência Ativa, Correspondência Passiva, Conto, Texto-Reflexão, Texto-Homenagem e etc.), e Autor (Hélio Oiticica, Lygia Clark, Mário Pedrosa, Guy Brett, incluindo diversos artistas plásticos, poetas, pensadores que faziam parte do círculo de amizade de Hélio, que se corresponderam durante sua trajetória, bem como, autores de textos nacionais e estrangeiros sobre os trabalhos de Hélio Oiticica). O arquivo conta ainda com uma base de dados vinculado a um programa de busca simples, que facilita em grande parte a localização de documentos específicos. Entretanto, como cada documento foi associado a um conjunto de palavras-chave, manualmente escolhidas, muitas palavras importantes deixaram de ser indexadas aos documentos. Exemplo disso são as palavras-chave desta pesquisa: 'construção de situação', 'situacionistas', 'sociedade do espetáculo', 'Guy Debord', que pelo fato de não estarem indexadas a nenhum documento, revelam, por sua vez, o ineditismo desta proposta. Diante deste fato, restou debruçar-se sobre este material e percorrê-lo, bem ao modo de uma deambulação labiríntica, na qual, apesar da infinidade de caminhos e direções que se abrem à frente, uma multiplicidade de eventos e encontros também se sucedem.

Este arquivo constitui-se o maior acervo documental sobre seu trabalho, graças ao espírito metódico e sistemático que Hélio Oiticica cultivou em paralelo ao seu espírito anárquico e experimental. Conforme Frederico Oliveira Coelho afirma, em Hélio Oiticica - um escritor em seu labirinto, Hélio cultivou a perspectiva do "arquivo 
enquanto uma forma de depositário da verdade”, não só como "lugar de memória, mas também como local de autoridade sobre os usos dessa memória”24. Coelho acrescenta que esta estratégia reproduzia um pensamento de Glauber Rocha e Rogério Duarte. Este último aconselhava que antes criar sua própria memória a ser transformado num mal entendido 25 . Desta forma, o sentido de 'desorientação' presente na ideia de labirinto foi recompensado pelas informações coletadas no caminho. Foram textos, pequenas anotações, cartas, esboços, bilhetes, cartões postais, que uma vez encontrados, reafirmavam os passos dados.

O corpus documental de Hélio Oiticica ou o "dispositivo delirante”, como definiu Celso Favaretto, é constituído por duas séries: produção artística e discurso 26 . Ambas igualmente importantes e complementares, uma vez que "os textos integram os experimentos, manifestando-se, em alguns momentos, como experimentação de linguagem verbal ${ }^{27}$. As análises do conjunto deste material, sobretudo dos períodos em que Hélio viveu em Londres (1968 - 1969) e Nova Iorque (1970-1978), revelam a proximidade de suas reflexões e proposições à teoria crítica desenvolvida pelos situacionistas. Alguns documentos ainda confirmam que Hélio conheceu e identificouse com a crítica desenvolvida por Guy Debord em A Sociedade do Espetáculo, bem como tinha ciência da existência da Internacional Situacionista, citando-os ou mesmo incorporando algumas de suas expressões, em textos-obras, textos-reflexão, cartas. Entre algumas das expressões citadas, destacam-se, por exemplo: espetáculo,

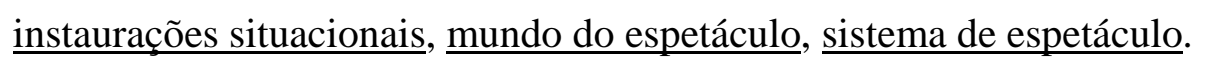

24 Coelho, Frederico Oliveira. Hélio Oiticica - Um escritor em seu labirinto. Revista Sibila. Rio de Janeiro, 30 de novembro de 2004. p. 218. In: Catalogue Raisonné, nº doc. 2587.04, p. 1-18.

25 Coelho, Frederico Oliveira. Hélio Oiticica - Um escritor em seu labirinto. Revista Sibila. Rio de Janeiro, 30 de novembro de 2004. p. 218. In: Catalogue Raisonné, no doc. 2587.04, p. 1-18.

26 Favaretto, Celso. A invenção de Hélio Oiticica. São Paulo: Editora da Universidade de São Paulo, 2000. p. 18.

27 Favaretto, Celso. A Invenção de Hélio Oiticica. São Paulo: Editora da Universidade de São Paulo, 2000. p. 17. 


\section{O Mapa do Labirinto}

Este trabalho esta organizado em três capítulos. O primeiro capítulo, "A Poética do Andar", apresenta e desenvolve os principais conceitos que articulam os objetos desta tese. Esses conceitos são retomados nos capítulos seguintes, quando busca-se, a partir da trajetória de Hélio Oiticica, reconstituir o desenvolvimento de sua poética do andar, bem como, estabelecer as relações dessa poética do andar com a formulação de seu ideário urbano.

O primeiro capítulo inicia com uma análise das atividades desenvolvidas nos eventos do Arte/Cidade, na cidade de São Paulo, realizados em 1994, "A cidade sem Janela" e em 1995, "Cidade e seus Fluxos". A pertinência da menção ao Arte/Cidade inaugurando os textos desta tese, dá-se à medida que a temática abordada em cada um destes eventos, bem como, as especificidades das intervenções realizadas por uma lista de artistas de renome, fazem emergir uma série de questões importantes sobre a cidade atual, lançando-nos à reflexão dos caminhos do planejamento urbano, do desenho das cidades e das intervenções do Capital no espaço urbano. Estas questões deságuam no tema da deambulação urbana, principalmente, quando o histórico da prática do andar como prática estética revela um conjunto de escritores, artistas, arquitetos e pensadores que apresenta, a partir de suas poéticas, o problema da apreensão e da representação das situações próprias dos espaços públicos na metrópole moderna, delineando uma teoria que critica as formas de fixação da sociedade capitalista e a perda cada vez maior do potencial de apropriação desses espaço públicos por seus moradores. Estas questões conduziram à formulação das seções "A Cidade como Espetáculo", "O Território Nômade", "O Andar como Experiência Estética" e "A Cidade e os Mapas".

O Capítulo 2 "A Deambulação Poética de Hélio Oiticica", explora a trajetória do artista Hélio Oiticica traçando o percurso no qual sua prática do andar foi sendo incorporada à suas proposições estéticas, sobretudo, na formulação do delirium ambulatorium. As seções desenvolvem-se a partir da sua deambulação na cidade do Rio de Janeiro, o ponto de partida, passando por Londres, Nova Iorque e Rio de Janeiro novamente. O comportamento labiríntico constituinte da deambulação urbana, está presente em seu 'ideário urbano' que assume a forma labirinto, o que justifica, por conseguinte, as análises realizadas no capítulo 3 "O Labirinto como Poética do Espaço". Neste último capítulo as discussões convergem na figura do labirinto, que 
aparece como fio condutor das discussões anteriores, e revela a dialética entre forma urbana e modos de vida. 


\section{A Poética do Andar}

Um horizonte de concreto chapado contra os nossos olhos. O muro de prédios se assemelha ao chão de pedra das calçadas e o fosco das fachadas espelhadas impede qualquer transparência. Coisas que se recusam a partir, sedimentadas, amontoando-se umas sobre as outras. Tudo é abarrotado, os espaços profusamente tomados por camadas de reboco, tapumes de madeira, vigas de ferro soterradas por improvisações de alvenaria, restos de trilhos e traquitanas, detritos e pó. Um palimpsesto formado pelos vários usos que tiveram as coisas. (Nelson Brissac Peixoto, 1994).

A descrição acima realizada por Nelson Brissac Peixoto diz respeito aos galpões do antigo Matadouro da Vila Mariana, em São Paulo. Seu texto abre o catálogo do primeiro Arte/Cidade 28 realizado em 1994, Cidade sem Janelas. Apesar do texto fazer referência direta a um espaço específico da cidade de São Paulo, por suas características, podemos imaginá-lo em qualquer cidade, ou, pensarmos que em todas as cidades deva existir um lugar como este, "uma paisagem intrincada (...), onde a visão é sempre parcialmente encoberta por obstáculos. Não há como apreender, de um só golpe, o conjunto do espaço, obrigando a percorrer este labirinto" 29 .

Em Cidade sem Janelas, Brissac nos apresenta a partir da descrição dos antigos galpões, "a cidade como um muro impenetrável e opaco", nos fala dos antigos abatedouros, como "resquícios mecânicos da atividade esquecida", "universo maquinal marcado pela corporeidade", "esforço humilde contra o mundo coagido pela força da

28 Arte/Cidade é um projeto de intervenção urbana com curadoria de Nelson Brissac Peixoto. O primeiro projeto ocorreu na cidade de São Paulo em 1994, denominado Cidade sem Janelas, o segundo projeto, A Cidade e seus Fluxos, também na cidade de São Paulo, ocorreu em 1995. A Cidade e suas Histórias foi o terceiro projeto, realizado em 1997. A região escolhida para a Cidade e suas Histórias foi a região da Estação da Luz e um trecho ferroviário que incluía locais significativos do período fabril da cidade: os silos do antigo Moinho Central, na Barra Funda, e os galpões e chaminés que restam das Indústrias Matarazzo, no bairro da Água Branca.

29 Peixoto, Nelson Brissac (curador). Cidade sem Janelas. Catálogo de Exposição Arte/Cidade, 1994. 
gravidade". As intervenções artísticas ali empreendidas constroem a psicogeografia ${ }^{30}$ do lugar, são pequenos ambientes no interior destes galpões que representam ambiências do mundo lá fora: "as janelas obstruídas da primeira sala não dão para nenhum horizonte. Nada as distingue daquelas pintadas na parede cega: todas abrem para dentro"31. É a própria imagem da cidade sem janelas, mas poderia ser da cidade real, que se volta para 'dentro', para os interiores da vida privada. Encontram-se também ambientes totalmente escuros que conduzem o visitante pelo desconhecido, como na proposta de Carlos Fajardo, na qual o visitante experimenta a desorientação espacial e é forçado a estabelecer uma relação tátil com o local. Esta desorientação subverte a lógica presente nas cidades, das placas de orientação de trânsito, dos mapas turísticos que indicam a próxima parada.

O visitante percorre o itinerário como um passeio, abrindo-se à sua frente um campo de experiências que somente a cidade do século XIX, a cidade baudelairiana permitiria. Ele percorre trajetos indefinidos de terrenos irregulares, cheio de odores, texturas e sons, aos poucos é conduzido à experimentação dos pedaços da cidade. São imagens de rostos anônimos reproduzidas em série, cartazes acumulados nas paredes: panfletos publicitários, cartazes de shows, propaganda eleitoral, que recria o ruído visual. Enquanto os ruídos sonoros são propagados em uma centena de alto-falantes distribuídos em cerca de oito ninhos espalhados pelo chão ("funcionam como esteiras mecânicas, carregando massas sonoras de canto a outro"), reproduzem chamadas de metrô, falas gravadas de discussões, conversas telefônicas. A cidade é revelada em sua materialidade, textura, densidade, como uma "massa bruta e informe"32.

Em 1995, o Arte/Cidade apresenta A Cidade e seus Fluxos ${ }^{33}$ com uma proposta bastante diversa da primeira. Enquanto na Cidade sem Janelas a apreensão dá-se a partir do passeio, numa área circunscrita, A Cidade e seus Fluxos apresenta uma zona sem traçado e sem fronteiras, nela não se passeia, desloca-se. As escalas são desproporcionais à experiência humana, e a consequência é o mergulho no fluxo

\footnotetext{
$30 \mathrm{O}$ termo psicogeografia foi criado pelos situacionistas e definido como o "estudo dos efeitos do meio geográfico, conscientemente planejado ou não, que agem diretamente sobre o comportamento afetivo dos indivíduos". Este conceito será retomado e aprofundado nas seções seguintes.

31 Referência à intervenção realizada por Marco Giannotti que pintou janelas de vermelho, usando pigmento puro e criou "um ambiente que em vez de emanar luz - como os paços sacros agraciados por vitrais - absorve toda a luminosidade na parede porosa e aveludada". Peixoto, Nelson Brissac. Cidade sem Janelas. Arte/Cidade. 1994.

32 Nelson Brissac Peixoto (curador). Catálogo de Exposição Cidade sem Janelas. 1994.

33 Nelson Brissac Peixoto (curador). Catálogo de Exposição A Cidade e seus Fluxos, 1995.
} 
contínuo e caótico do espaço urbano. Trata-se, na verdade, de "um lugar de passagem, simbolizado pelo viaduto do Chá. Num dos pólos, o prédio da Eletropaulo. Do lado oposto do Anhangabaú, a antiga sede do Banco do Brasil. E ainda o edifício Guanabara, na esquina da Av. São João. Além disso, a área do vale e as ruas circundantes"34.

Este extenso campo urbano encontra-se saturado de informações, não admite nenhuma inscrição, indícios ou pistas, nenhuma tentativa de se construir um marco, com risco deste se perder, misturando-se com o resto da cidade. Neste espaço urbano a única possibilidade de mapeamento seria através da aerofotogrametria.

Este campo urbano relaciona-se, à vertigem, pela sensação da proporção descomunal diante da escala humana, à virtualidades, pelas "coisas que não deixam rastros"35. Sua apreensão não se dá mais pela visão humana, capturá-lo somente maquinalmente, por aparelhos automáticos. Para ver o que os olhos não mais veem: dispositivos de telescopagem, periscópios, feixes de luz. O "Detetor de Ausências" de Rubens Mano, por exemplo, são dois grandes refletores instalados sobre torres ao lado do Viaduto do Chá, que ao atravessar os passantes, uma silhueta é instantaneamente recortada. A fotografia é colocada em escala com a cidade, "retrata o contato do indivíduo com o urbano"36, ou seja, retrata a 'ausência', a relação perdida.

Enquanto essas intervenções artísticas procuram resgatar emoções, refazer relações, evidenciar o detalhe, estas mesmas 'incisões' no espaço revelam, em contrapartida, o crescimento acelerado das cidades, a desqualificação de seus espaços e, consequentemente, a desterritorialização permanente, da qual o indivíduo está submetido.

Esta desterritorialização pode ser entendida a partir da 'máxima', presente nas sociedades contemporâneas, de que um indivíduo hoje pode estar em 'todos os lugares' e ao mesmo tempo não se sentir 'em casa' em lugar nenhum. O italiano Franco La Cela em seu livro Perdersi L'uomo senza ambiente, debruça-se sobre este tema, o da relação do espaço da cidade com o indivíduo, sobretudo, de sua identificação com o espaço da cidade.

\footnotetext{
34 Nelson Brissac Peixoto (curador). Catálogo de Exposição A Cidade e seus Fluxos, 1995.

35 Nelson Brissac Peixoto (curador). Catálogo de Exposição A Cidade e seus Fluxos, 1995. 36 idem.
} 
A palavra perdersi refere-se à prática aleatória do vagar pela cidade como forma de expressão artística, presente tanto nas artes como na literatura. A essa prática, surgiram inicialmente os termos flânerie e deriva. O flâneur caracterizado pelo poeta Charles Baudelaire é o ponto de partida de uma linhagem de artistas que irão confrontar o problema da apreensão e da representação das situações próprias dos espaços públicos na metrópole moderna. Posteriormente, farão uso da prática da errância urbana os dadaístas, os surrealistas, a Internacional Situacionista, o grupo Fluxus $^{37}$. O termo perdersi diz respeito ao encontro com espaços antes desconhecidos da cidade, inabitados, ocultos, que apenas o olhar distraído é capaz de capturar. Relaciona-se, sobretudo, com a deriva situacionista ${ }^{38}$, uma vez que também procura devolver o aspecto indeterminado e radicalmente anárquico da experiência espacial, resgatando a crítica social e política no contexto das cidades contemporâneas.

O tema da errância urbana reaparece nos dias de hoje imerso ainda de uma aura de atualidade, principalmente, quando o espaço urbano experimenta uma verdadeira inversão de seus valores, deixando de ser o lugar onde se habita, para ser o lugar onde se consome, protegido tanto quanto possível de todo e qualquer tipo de uso 'inadequado', como dos sem tetos. Trata-se de um espaço público reduzido em suas possibilidades.

La Cela aponta que esta pobreza dos espaços públicos deve-se à formação dos arquitetos urbanistas, que não são preparados em trabalhos de campo, nem adotam uma ótica fenomenológica em seus 'estudos de caso'. Além dos engenheiros, planificadores, developpers, e, sobretudo, os arquitetos, pensarem suas obras como uma importante empresa publicitária, como um espetáculo que oferece aos cidadãos (ou à posteridade), a memória de sua genialidade artística. O resultado é o primado da imagem, no senso mais mediático possível, em detrimento da experiência espacial, como se a arquitetura tivesse passado do privilégio do projeto a um privilégio da mediatização ${ }^{39}$.

37 Hollevoet, Christel. Déambulations de la flânerie et la dérive dans la ville à l'appréhension de l'espace urbain dans fluxus et l'art conceptuel. Parachute, n. 68. Canadá, (out., nov., dez.), 1992.

38 A deriva situacionista foi definida como o "modo de comportamento experimental ligado às condições da sociedade urbana: técnica da passagem rápida por ambiências variadas. Diz-se também, mais particularmente, para designar a duração de um exercício contínuo dessa experiência". Este conceito será retomado e aprofundado nas seções seguintes.

39 La Cela, Franco. Perdersi. L'uomo senza ambiente. Laterza, 2000. p. 130-131. 
No campo do urbanismo, o problema pode ser observado como um verdadeiro projeto do "fascismo arquitetônico", como denominou La Cela. O urbanismo com sua prerrogativa de ser o responsável pela segurança, acabou por estabelecer uma rígida divisão dos corpos sociais, como é o caso dos condomínios fechados. Além da transformação do espaço público em um enorme shopping center, onde não é mais adequado 'perder tempo' 40 .

Segundo Guy Ernest Debord este primado da imagem é o que define a sociedade moderna (ou sociedade do espetáculo), na qual as relações sociais são mediadas por 'imagem'. Nesta sociedade todas as forças técnicas da economia capitalista, o que inclui o urbanismo, operam como técnica da separação ${ }^{41}$. Trata-se de um sistema econômico fundado no isolamento:

Do automóvel à televisão, todos os bens selecionados pelo sistema espetacular são também suas armas para o reforço constante das condições de isolamento das "multidões solitárias"42.

\subsection{A Cidade como Espetáculo}

O urbanismo é a tomada de posse do ambiente natural e humano pelo capitalismo que, ao desenvolver sua lógica de dominação absoluta, pode e deve agora refazer a totalidade do espaço como seu próprio cenário. Guy Debord, 1967.

Guy Debord em La Société du Spectacle, 1967, inicia o capítulo VII A ordenação do Território, citando O Príncipe, de Maquiavel, em trecho que ressalta o poder dos habitantes de uma cidade acostumada a viver livre, que possuem como

\footnotetext{
40 idem. p. 135-136.

41 Debord, Guy Ernest. A Sociedade do Espetáculo. Tradução Estela dos Santos Abreu. Rio de Janeiro: Contraponto, 1997. Tese 171-172.

42 Debord, Guy Ernest. A Sociedade do Espetáculo. Tradução Estela dos Santos Abreu. Rio de Janeiro: Contraponto, 1997. Tese 28.
} 
refúgio de suas rebeliões a palavra liberdade ${ }^{43}$. Debord escolhe o tema da liberdade para em seguida destrinchar sua teoria sobre o espaço espetacular das cidades, ou seja, o espaço urbano subordinado à produção capitalista, no qual o urbanismo representa a "a realização moderna da tarefa permanente que salvaguarda o poder de classe" 44 .

Porém, antes de A ordenação do território, Debord propõe discutir A Mercadoria como Espetáculo. Segundo Debord, a mercadoria como espetáculo é resultado da dominação da mercadoria sobre a economia. Uma vez que a economia é a base material da vida social, a mercadoria como espetáculo seria o prenúncio da cidade espetacular: "o espetáculo é o momento em que a mercadoria ocupou totalmente a vida social", "não apenas a relação com a mercadoria é visível, mas não se consegue ver nada além dela: o mundo que se vê é o seu mundo"45. É a mercadoria que se "encarrega dos "lazeres e da humanidade", é ela também "que dissolve a autonomia e a qualidade dos lugares".

Em 1935, Walter Benjamin buscou as origens da criação do universo das mercadorias no século XIX, lançando luz para o surgimento das passagens, precursoras das atuais lojas de departamento, bem como das exposições universais. Ao explicar a materialidade das passagens como "centro das mercadorias de luxo", Benjamin enfatiza as condicionantes da sua arquitetura, ou seja, a iluminação a gás e a construção em ferro.

Segundo Benjamin, o surgimento das passagens anunciou o destino das artes e da arquitetura. Primeiramente, Benjamin leva em consideração a construção do universo das mercadorias para afirmar que a partir dele a arte passou a ser colocada a serviço do comerciante. Posteriormente, observa que a partir do uso do ferro na construção, que propiciou pela primeira vez na história uma construção artificial, a arquitetura passou a ser dominada pelo princípio construtivo.

Este novo meio de produção que privilegia o efêmero, tanto pela transitoriedade das mercadorias, como da própria arquitetura, a partir de um novo sistema construtivo, influencia o próprio pensamento sobre o espaço das cidades.

\footnotetext{
43 "E quem se torna Senhor de uma cidade acostumada a viver livre e não a destrói, que aguarde ser destruído por ela, porque ela sempre tem como refúgio de suas rebeliões a palavra liberdade e seus velhos costumes, os quais nem pela extensão do tempo nem por nenhum benefício serão jamais esquecidos. E por mais coisas que se façam ou que se ofereçam, a menos que se expulsem ou dispersem os habitantes, nunca eles esquecerão essa palavra e esses costumes..." Maquiavel (O Príncipe)

44 Debord, Guy. A Sociedade do Espetáculo, p. 113 (tese 172).

45 ibid. p. 30 (tese42).
} 
Benjamin explica que essas experiências da sociedade e suas fantasias imagéticas terão identificação na utopia de Fourier, que transforma as passagens, que serviam originalmente a fins comerciais, em residências. Fourier cria a partir de seu falanstério uma "cidade feita de passagens" 46.

Por sua vez, as exposições universais completam a construção deste universo das mercadorias, sendo responsáveis pela primeira vez por um grande número de pessoas que se deslocam para ver as mercadorias. Observa-se também o uso da mercadoria colocado em segundo plano. Segundo Debord, o valor de uso das mercadorias é corroído pela economia mercantil superdesenvolvida47 e explica: "a satisfação que a mercadoria abundante já não pode dar no uso começa a ser procurada no reconhecimento do seu valor como mercadoria: é a liberdade soberana da mercadoria"48.

Entretanto, desta sociedade que vislumbra o universo das mercadorias no final do século XIX, a partir das passagens e exposições universais, à sociedade dos anos 1960, Debord identifica um processo de abstração generalizada. Segundo o qual, na sociedade atual as relações sociais são mediadas por imagens (imagens que se tornaram seres reais e motivações eficientes de um comportamento hipnótico). Em outras palavras, Debord explica que assim como houveram épocas em que o sentido privilegiado era o tato, neste mundo que não pode mais ser tocado diretamente, o indivíduo serve-se da visão como o sentido privilegiado. Entretanto, como o sentido da visão é o sentido mais abstrato, o sujeito tende mais à mistificação, completa Debord.

Desta forma, compreende-se que a ideia de fetiche no século XIX, segundo Walter Benjamin, encontra-se encarnada na mercadoria, objetivando nas relações de troca as condições subjetivas de sua produção, enquanto o fetiche, segundo a análise de Debord, diz respeito à circulação de imagens, ou seja, a forma imaterial e tecnologicamente superdesenvolvida das mercadorias.

Esta "fantasmagoria da cultura capitalista"49, alcançando o domínio do urbanismo, corroborou a construção do espaço da cidade moderna. As sucessivas

\footnotetext{
46 Benjamin, Walter. Paris, A Capital do Século XIX. Exposé de 1935. p. 41

47 Guy Debord, E. A Sociedade do Espetáculo. p. 34 (tese 48).

48 Guy Debord, E. A Sociedade do Espetáculo. p. 44-45 (tese 67).

49 Em seu Exposé de 1939, Benjamin esclarece que a representação coisificada da civilização é devedora do século XIX, das novas formas de vida e das novas criações de base econômica e técnica, e
} 
transformações que a cidade sofreu para atender à modernização e seu crescimento vertiginoso recaíram numa 'fantasmagoria do espaço', sobretudo, por colocar em evidência o destino das artes e da arquitetura, outrora apontado por Benjamin.

Exemplo disso, encontra-se no ideal urbanístico de Haussmann e em sua tendência em valorizar necessidades técnicas com pseudofinalidades artísticas. Ou seja, enquanto seus longos traçados de ruas pareciam remeter à identificação das instituições do poder laico e espiritual da burguesia, Haussmann talvez estivesse apenas buscando proteger a cidade contra a eventualidade de uma guerra civil, impedindo definitivamente, a partir das largas ruas, a construção de barricadas ${ }^{50}$.

A par dessas transformações urbanísticas, a população perde sua identificação com a cidade, emergindo um sentimento de estranhamento e de 'desenraizamento'. Guy Debord analisa, diante desse caráter desumano da cidade, que todo "o esforço de todos os poderes estabelecidos, desde as experiências da Revolução Francesa, para ampliar os meios de manter a ordem na rua, culmina afinal com a supressão da rua" 51 .

O rápido crescimento das cidades e o agravamento dos problemas de trânsito, além da proliferação dos subúrbios, no início do século $\mathrm{XX}$, também são condicionantes para a formulação de um pensamento urbano modernista que, priorizando a organização deste espaço, irá contribuir também para a supressão da rua. Esta mentalidade urbanística modernizadora procura resolver os problemas da cidade de modo muito semelhante à concepção haussmanniana, ou seja, demolindo o 'velho espaço caótico' e incorporando a ordem a partir de largas ruas, que agora menos do que querer proteger as cidades das barricadas, procura desafogar o trânsito de veículos.

Os ideais urbanísticos de Le Corbusier, no século XX, ilustram esta mentalidade. na qual a rua é vista como uma "máquina para o tráfego". Desta forma, diferentemente do homem do século XIX, e da Paris de Baudelaire, onde é possível encontrar o "homem na rua", tem-se o "homem no carro". Na visão de Le Corbusier o novo mundo nasce inteiramente ligado por "super-rodovias aéreas, servido por

denomina este processo de fantasmagoria. Benjamin, Walter. Paris, Capital do Século XIX. Exposé de 1939. p. 53.

50 Benjamin ainda explica que Haussmann dissimulava suas 'perspectivas', feitas de fileiras de ruas, a partir de uma tela apenas descoberta antes da inauguração: "uma tela que se levanta como se descobre um monumento, e a vista se abria então para uma igreja, uma estação, uma estátua equestre ou qualquer outro símbolo da civilização". Benjamin, Walter. Paris Capital do Século XIX. Exposé de 1939. p. 64.

51 Guy Debord, E. A Sociedade do Espetáculo. p. 113 (tese 172). 
garagens e shopping-centers subterrâneos”52. Esta mentalidade urbanística reduz brutalmente as práticas espaciais e as possibilidades de apropriação do espaço da cidade pelo indivíduo, criando um mundo espacialmente e socialmente segregado.

Segundo Debord está justamente na separação de funções proposta por Le Corbusier na Carta de Atenas a monotonia da vida cotidiana, responsável por sua vez pela passividade e alienação na sociedade. Para Debord, o urbanismo funciona como elemento de salvaguarda do poder de classe, que atomiza os trabalhadores, perigosamente reunidos pelas condições de produção; que deve ser propício ao controle e à manutenção da ordem (supressão das ruas, isolamento dos trabalhadores, com reintegração controlada segundo as necessidades de produção e consumo em uma pseudo-coletividade). Controle este via imagens-espetaculares, com as quais povoa-se o isolamento e que adquirem seu pleno poderio justamente pelo isolamento do indivíduo.

Trata-se de um urbanismo unificador, homogeneizador e banalizador do espaço abstrato das mercadorias. A lógica do urbanismo como necessidade capitalista é a da separação dos homens (atomização), operando inversamente no plano abstrato das mercadorias (unificação). Afinal, segundo Debord, a vida cotidiana é assim a vida privada, domínio da separação e do espetáculo, pois o "espetáculo reúne o separado, mas o reúne como separado" 53.

A crítica ao urbanismo separatista também é foco da americana Jane Jacobs em livro de 1960, “Morte e Vida de Grandes Cidades”. Em sua crítica, Jacobs sinaliza que a monotonia, a esterilidade e a vulgaridade que os espaços da cidade apresentam são resultados de um urbanismo separatista. Em oposição, Jacobs defende a diversidade espontânea da rua e o uso misto das quadras, como símbolo de vitalidade. Para exemplificar sua máxima, Jacobs analisa um distrito de Boston chamado North End, uma verdadeira zona de cortiço que apresenta características que qualquer autoridade ou qualquer pessoa esclarecida pelos ensinamentos do planejamento ortodoxo, diriam serem nocivas: próximo à indústria, comércio diversificado e complexamente misturado com as residências, alta densidade habitacional, poucas áreas verdes, quadras curtas, edifícios antigos, ruas “mal traçadas”. Porém, apesar das características distantes dos ideais de ordem que dita a cartilha do planejamento moderno ortodoxo,

52 Berman, M. Tudo que é sólido desmancha no ar: a aventura da modernidade. p. 161.

53 Debord, Guy. A sociedade do espetáculo. Rio de Janeiro: Contraponto, 1997. Tese 29. p. 23. 
North End apresentou-se, a partir do final dos anos 50, surpreendentemente mais bem cuidada. A diversidade do espaço que mistura residências, pequenos comércios, mercearias, serralheria, carpintaria, foram responsáveis pela ocupação das ruas, dando vida ao local: crianças brincando, gente fazendo compras, passeando, conversando, proporcionando a "atmosfera de alegria, companheirismo e bem-estar contagiante”, contrariando todo e qualquer pressuposto advindo de algum planejador.

Em O Urbanismo em Fim de Linha ${ }^{54}$, de Otília Arantes o urbanismo moderno também aparece como responsável pelas questões então vigentes: a dispersão, no lugar de integração; a diversidade, ao invés das oposições clássicas de alteridade; a novidade, como distorção mercadológica do novo; a valorização instantânea do passado, uma memória sem memória. Em sua análise sobre o projeto moderno, Otília Arantes aponta para o processo de estetização da vida, para a "museificação" das cidades $^{55}$, para a "consagração da superfície da aparência estética", aproximando-se em vários pontos do discurso crítico desenvolvido por Debord:

Recrudecimento do fetichismo portanto, porém sob forma soft. A reificação das relações sociais toma agora forma de uma irrealização do mundo convertido em imagens, da publicidade às artes eletrônicas, passando pela arquitetura simulada, cenarística etc ${ }^{56}$.

\subsection{O Território Nômade}

Os conceitos que giram em torno de nomadismo e sedentarismo relacionam-se às formas específicas de territorialidade. Enquanto a forma de territorialidade dos nômades é caracterizada pela mobilidade e dispersão geográfica, a territorialidade

\footnotetext{
54 Arantes, Otília Beatriz Fiore. Urbanismo em fim de linha e outros estudos sobre o colapso da modernização arquitetônica. São Paulo: EDUSP, 1998.

55 Arantes, Otília Beatriz Fiore. Urbanismo em fim de linha e outros estudos sobre o colapso da modernização arquitetônica. São Paulo: EDUSP, 1998. p. 34.

56 Arantes, Otília Beatriz Fiore. Urbanismo em fim de linha e outros estudos sobre o colapso da modernização arquitetônica. São Paulo: EDUSP, 1998.
} 
sedentária tem como princípio a fixação e a concentração espacial ${ }^{57}$. Para os nômades, "seu acampamento é sempre provisório, um lugar prestes a ser abandonado", enquanto o sedentário está inserido numa 'dimensão disciplinadora da vida cotidiana', 'confinado' numa rede urbana que "esquadrinha o território físico e geográfico, configurando-o como um aparelho de captura de fluxos os mais diversos - de homens, mercadorias, ideias e desejos"58.

Em seu Tratado de Nomadologia, Gilles Deleuze e Félix Guattari, consideram o nomadismo e o sedentarismo duas ciências opostas, ou melhor, com uma "tensãolimite" entre elas, onde têm-se a ciência nômade de máquina de guerra de um lado, e a régia de Estado do outro ${ }^{59}$. A ciência 'régia' diz respeito "a arte de governar os homens ou de exercer o aparelho de Estado"60, enquanto o termo 'máquina de guerra' advém da reflexão de que a guerra é algo exterior à soberania do aparelho de Estado. O Estado dispõe de uma violência que não passa pela guerra",

o Estado emprega policiais e carcereiros de preferência a guerreiros, não tem armas e delas não necessita, age por captura mágica imediata, "agarra" e "liga", impedindo qualquer combate. Ou então o Estado adquire um exército, mas que pressupõe uma integração jurídica da guerra e a organização de uma função militar 61 .

Entretanto, uma forma de nos aproximarmos de suas características intrínsecas é pensarmos sobre o modelo de trabalho para cada uma dessas 'ciências'. Para tal entendimento é preciso levar em consideração que para o Estado não há nenhuma vantagem num corpo de trabalho nômade. Aliás, muito pelo contrário, uma das principais funções do Estado é a de

57 Andrade, Carlos Roberto Monteiro de. Ferrovias, nômades e exilados. in Revista Risco (revista de pesquisa em arquitetura e urbanismo, IAU USP), ano $1, \mathrm{n}^{\circ} 1,2^{\circ}$ semestre de 2003. p.17-22.

58 ibid, p. 19.

59 "Estamos diante de duas concepções da ciência, formalmente diferente; e, ontologicamente, diante de um só e mesmo campo de interação onde uma ciência régia não para de apropriar-se dos conteúdos de uma ciência nômade ou vaga, e onde uma ciência nômade não para de fazer fugir os conteúdos da ciência régia. No limite, só conta a fronteira constantemente móvel". Deleuze, Gilles e Guatarri, Félix. Tratado de Nomadologia: A Máquina de Guerra. in Mil Platôs, Capitalismo e Esquizofrenia. v. 5. Tradução Peter Pál Pelbart e Janice Caiafa.

60 Deleuze, Gilles e Guattari, Félix. O Liso e o Estriado. p. 181.

61.Deleuze, Gilles e Guattari, Félix. Tratado de Nomadologia: A Máquina de Guerra. in Mil Platôs, Capitalismo e Esquizofrenia. v. 5. Tradução Peter Pál Pelbart e Janice Caiafa. p. 12. 
fixar, sedentarizar a força de trabalho, regrar o movimento do fluxo de trabalho, determinar-lhe canais e condutos, criar corporações no sentido de organismos, e, para o restante, recorrer a uma mão de obra forçada, recrutada nos próprios lugares (corvéia) ou entre os indigentes 62 .

Em contrapartida, nas ciências nômades os agenciamentos são passionais, são composições de desejo. Esta é a grande oposição entre os dois modelos de trabalho: a organização e a formação. Isto porque nas ciências nômades, a ciência não está destinada a tomar um poder, nem ao menos tem interesse num desenvolvimento autônomo, porque "subordinam todas as suas operações às condições sensíveis da intuição e da construção"63. Na prática, podemos comparar os planos que cada uma dessas ciências adotam para a execução de suas tarefas. Enquanto pode-se pensar, no caso de uma organização nômade, num plano sendo traçado diretamente no solo, na ciência régia, o plano é traçado sobre o papel do arquiteto fora do canteiro ${ }^{64}$.

A necessidade de sedentarizar a força de trabalho resulta na fixação e formação de cidades. A organização das cidades, por sua vez, representa o modo no qual o Estado se manifesta no território. O controle do Estado a partir do território dá-se tanto por uma estrutura externa, a urbanização do território, que cria uma rede de cidades interligadas por meios de comunicação, como por uma estrutura interna, também marcada pela noção de rede: redes de saneamento, viárias, de comunicação, de distribuição de energia, hospitais, entre outras 65 .

A urbanização das cidades diz respeito ao espaço 'estriado', o espaço sedentário, ou instituído pelo aparelho de Estado, segundo Deleuze e Gattari: "uma das tarefas fundamentais do Estado é 'estriar' o espaço sobre o qual reina, ou utilizar os espaços lisos como um meio de comunicação a serviço de um espaço estriado"66. O espaço 'liso' seria, portanto, o espaço nômade, ele insere-se entre dois espaços estriados, e por isso mesmo, nunca é totalmente independente: "é controlado por esses

62 Deleuze, Gilles e Guattari, Félix. Tratado de Nomadologia: A Máquina de Guerra. in Mil Platôs, Capitalismo e Esquizofrenia. v. 5. Tradução Peter Pál Pelbart e Janice Caiafa. p. 34.

63 ibid. p. 41.

64 ibid. p. 35.

65 Andrade, Carlos Roberto Monteiro de Andrade. Ferrovias, nômades e exilados. in Revista Risco (revista de pesquisa em arquitetura e urbanismo, IAU USP), ano 1, n.1, $2^{\circ}$ semestre de 2003. p.17-22.

66 Deleuze, Gilles e Guattari, Félix. Tratado de Nomadologia: A Máquina de Guerra. in Mil Platôs, Capitalismo e Esquizofrenia. v. 5. Tradução Peter Pál Pelbart e Janice Caiafa. p. 59. 
dois lados que o limitam, que se opõem a seu desenvolvimento e lhe determinam, tanto quanto possível, uma função de comunicação"67.

O Estado procura ao máximo controlar, vistoriar e mensurar, entradas e saídas, fluxos, velocidades, e o faz a partir de pedágios, barreiras alfandegárias, inspecionando estradas e etc., são os 'aparelhos de captura'. Neste sentido, o mar seria o principal espaço liso e o que "mais cedo se tentou estriar"68, "a estriagem dos mares se produziu na navegação de longo curso"69. Porém, para entender o por quê do mar ser o espaço liso por excelência é preciso considerar que tanto no espaço estriado como no espaço liso existem pontos, linhas e superfícies, no entanto, no espaço estriado, as linhas, os trajetos, tem tendência a ficarem subordinados aos pontos: vai-se de um ponto a outro. Segundo Paul Virilio, no mar não se vai de um ponto a outro, "os pontos estão subordinados ao trajeto"70, assim como no ar e no deserto. Desta forma, observa-se que a dominação tanto pelo mar, como pelo ar dá-se por um ponto qualquer "ele é ocupado com um vetor de desterritorialização em movimento perpétuo"71.

As formas de controle são atualizadas a todo o momento pelo Estado que vê as práticas nômades como uma ameaça à estrutura social estabelecida. Estes processos, somados a uma dificuldade cultural e histórica que associa o nomadismo à guerras e epidemias, acaba funcionando, nos dias de hoje, como inibidores de práticas nômades, segundo o historiador francês Daniel Roche, em Humeurs vagabondes: de la circulation des hommes et de l'utilité des voyages ${ }^{72}$.

67 Deleuze, Gilles e Guattari, Félix. Tratado de Nomadologia: A Máquina de Guerra. in Mil Platôs, Capitalismo e Esquizofrenia. v. 5. Tradução Peter Pál Pelbart e Janice Caiafa. p. 57.

68 "O espaço marítimo foi estriado em função de duas conquistas, astronômica e geográfica: o ponto, que se obtém por um conjunto de cálculos a partir de uma observação exata dos astros e do sol; o mapa, que entrecruza meridianos e paralelos, longitudes e latitudes, esquadrinhando, assim, regiões conhecidas ou desconhecidas". idem, O Liso e o Estriado, p. 186.

69 Deleuze e Guattari, O Liso e o Estriado, p. 186.

70 ibid. p. 184.

71 ibid. p. 61.

72 Daniel Roche baseou suas pesquisas nas sociedades ocidentais dos séculos XVI, XVII e XVIII, e identificou já nessas sociedades uma conformação em torno da ideia de imobilidade, onde a "finalidade é fora do tempo, é a redenção, qual seja a cultura religiosa". Pois, mesmo após a Reforma Religiosa, "a hierarquia orgânica, a expressão dessa concepção sagrada e fixante do mundo, impõe que se fique preso a um lugar, a essa condição". Roche, Daniel. Humeurs vagabondes: de la circulation des hommes et de l'utilité des voyages. França: Edições Fayard, 2004. 
Atualmente, observa-se nas metrópoles contemporâneas o desaparecimento da figura do nômade e o crescimento do número de exilados ${ }^{73}$. Os nômades e os exilados podem apresentar modos de sobrevivência semelhantes, entretanto, distinguem-se substancialmente. O verdadeiro nômade não reclama qualquer direito de cidadania, enquanto o exilado é aquele que perdeu sua cidadania e clama pelo seu território do qual foi expulso. O nômade vê a cidade apenas como local de passagem, locus transitório, o exilado busca apesar da precariedade de seus abrigos, reconstruir o traçado sedentário, num desenho que reafirma o esquema urbano tradicional ${ }^{74}$.

Os exilados ou os 'nômades urbanos contemporâneos' são os sem-teto, os camelôs, os favelados, os migrantes que adotam procedimentos nômades: eles não dispõem de dispositivos de planejamento, suas ações são ditadas pelas necessidades de sobrevivência individual ${ }^{75}$. Os aparatos por eles construídos representam as 'máquinas de guerra'. A diferença encontra-se nas tentativas de ocupação dos espaços da cidade, numa busca de 'sedentarizar', pois desejam a cidade como lugar fixo: o comércio informal ocupa praças e ruas, as favelas tomam os espaços intersticiais (terrenos vagos, beiras de rio, os desvãos de viadutos e margens de autopistas), os moradores de rua ocupam as calçadas, marquises e entradas de edifícios.

Desta forma, pode-se pensar o espaço da favela como um espaço 'liso', ele pode estar no interior das cidades ou nas franjas urbanas, mas está sempre 'entre'. Possuem uma natureza diferente do espaço estriado, instituído pelo Estado, porém, relaciona-se com o espaço estriado de formas variáveis, possuem uma distinção por direitos, mas se misturam: "eles não se comunicam entre si da mesma maneira": "é um espaço liso que é capturado, envolvido por um espaço estriado, ou é o espaço estriado que se dissolve num espaço liso, que permite que se desenvolva um espaço liso?"76

O espaço estriado prolonga-se de forma cadenciada, numa trama alternada, reticular, métrica, pode até possuir uma trama complexa, porém são variáveis e constantes, entre fixos e móveis. Ao contrário, o espaço liso desenvolve-se num traçado aberto, em todas as direções e sentidos, e mesmo quando é composto por um

\footnotetext{
73 Andrade, Carlos Roberto Monteiro de. Ferrovias, nômades e exilados. in Revista Risco (revista de pesquisa em arquitetura e urbanismo, IAU USP), ano 1, n.1, $2^{\circ}$ semestre de 2003. p.17-22.

74 idem.

75 Peixoto, Nelson Brissac. As Máquinas de Guerra Contra os Aparelhos de Captura. Revista Arte/Cidade. São Paulo: Editora SENAC, 2002.

76 Deleuze e Guattari, "O Liso e o Estriado", p. 180.
} 
elemento único, possui ritmo, tamanhos, formas e texturas variadas. Aí está a comparação levantada por Deleuze e Guattari ao analisar os espaços lisos e estriados como as tramas do tricô em oposição a do crochê, ou a do bordado em oposição a do patchwork 77 .

A trama na qual constitui-se a favela diz respeito a este tecido maleável, que se expande de forma orgânica, a partir de um crescimento espontâneo, diferenciando-se do espaço urbano planificado dos arquitetos e urbanistas. Observa-se a terra batida em oposição ao asfalto, os caminhos tortuosos em oposição à ortogonalidade, os diferentes materiais, cores, e texturas utilizados na fabricação dos abrigos, em oposição à predominância do concreto nas edificações. Por isso, também entende-se que quanto mais um espaço é estriado, "quanto mais regular é o entrecruzamento", mais o espaço tende a tornar-se homogêneo. E se a cidade formal aparentemente comunica-se com o espaço informal da favela, "é somente porque o estriado não chega ao seu ideal de homogeneidade perfeita sem que esteja prestes a produzir novamente o liso, seguindo um movimento que se superpõe àquele do homogêneo, mas permanece inteiramente diferente dele"78.

O processo de territorialização da favela aproxima-se sobremaneira das ocupações de uma 'ciência nômade', são ocupações naturais, 'selvagens', não seguem modelo, nem projeto, seu crescimento é rizomático.

O conceito de rizoma também desenvolvido por Deleuze e Guattari diz respeito a um sistema de multiplicidade, opõe-se ao modelo arborescente e unitário do pensamento e ao sistema árvore-raiz ou radícula. O rizoma tem como prerrogativa o movimento, a capacidade de se reconstituir mesmo após sofrer ruptura, seu crescimento "é muito diferente da árvore ou da raiz, que fixam um ponto, uma ordem". Em contrapartida, a cidade formal, planejada ou a cidade dos arquitetos e urbanistas diz respeito ao sistema arborescente, de raízes fixas, organizada como uma árvore.

No princípio da multiplicidade presente no rizoma o processo é mais importante que a imagem formal, constitui-se como uma rede, seus pontos não são fixos, deslocam-se, e por isso produzem desterritorialização. Em contrapartida, o modelo arborescente recusa a desterritorialização, está baseado na ideia de raiz, na fundação, na sedentarização. O modelo da multiplicidade, ao contrário do modelo

77 Deleuze e Guattari, O Liso e o Estriado, p. 197-198.

78 idem. 
formal, não possui ordem, hierarquia, nem simetria: "qualquer ponto de um rizoma pode ser conectado com qualquer outro, e deve sê-lo. É muito diferente da árvore e da raiz, que fixam um ponto, uma ordem"79. O resultado é um espaço labiríntico, sem escala precisa, na qual a arquitetura é ao mesmo tempo 'paisagem', enquanto o percurso é o próprio labirinto.

O filósofo Mário Perniola comenta que a imagem de um território como um labirinto, sem centro, nem periferia, sem nenhuma regularidade, seria a única experiência não reificada do espaço, porque se resolve inteiramente na aventura temporal. Uma arquitetura labiríntica representa um lugar privilegiado para a errância, uma vez que para conhecê-lo é preciso a presença concreta, física e existencial do indivíduo errante. Todas as outras formas de percepção não são insuficientes, mas qualitativamente inadequadas. A fotografia, por exemplo, deve ser feita somente nos interiores, entretanto, também transforma os interiores em fachada, condicionando a percepção atribuindo a tudo o caráter reificado do espetáculo ${ }^{80}$.

Desta forma, enquanto a imagem de uma cidade labiríntica relaciona-se a uma organização urbana assimétrica, composta por estradas curvas que garantem a surpresa, o dinamismo e a riqueza espacial, a imagem de uma cidade antilabiríntica diz respeito a uma construção baseada em princípios geométricos, no emprego da linha reta, de dimensões uniformes, onde as repetições monótonas são a própria expressão de uma mentalidade e de um modo de viver formal, anônimo, burocrático e passivo ${ }^{81}$.

\subsection{O Andar como Experiência Estética}

Mesmo a cidade mais estriada secreta espaços lisos.

Deleuze e Gattari.

79 Deleuze, Gilles e Guattari, Félix. Mil Platôs, V1.

80 Perniola, Mario. Appunti per una storia dell'urbanistica labirintica. Revista di Estetica. Ano XIII, Fascículo II, 1968. (231-251) p.236.

81 idem. 
As tentativas de estabelecer uma teoria e uma prática das relações entre o passeio, o território e a paisagem, remontam ao século XVIII, quando nasce um 'movimento da sensibilidade', marcado pela exploração dos sentimentos e das emoções humanas na literatura. Deste período, destaca-se Devaneios do Caminhante Solitário, de Jean-Jacques Rousseau (1712-1778) ${ }^{82}$. Este seu último trabalho, escrito em 1776, reforça a crença na qual o homem é um ser naturalmente bom, que a bondade é corrompida pela sociedade e, portanto, é preciso conectar-se com a natureza para voltar à virtude primitiva ${ }^{83}$. Além disso, em Devaneios do Caminhante Solitário, a natureza aparece como o lugar privilegiado da alma humana em busca da serenidade, do devaneio, da felicidade e do amor, enquanto a cidade é considerada um lugar nocivo.

Essa obra diz muito sobre o próprio Rousseau naquele momento: solitário, reflexivo e rejeitado pelas ideias que defendia ${ }^{84}$. Trata-se dos registros de suas caminhadas associadas à reflexão, na busca de um exame íntimo e no entendimento de sua real condição humana. São nessas caminhadas solitárias, que conseguia ver-se por "inteiro", experimentando em muitas delas, as "delícias internas que as almas afetivas e suaves encontram na contemplação" 85 .

Tendo concebido, portanto, o projeto de descrever o estado habitual de minha alma na mais estranha condição em que jamais possa se encontrar um mortal, não vi maneira mais simples e mais segura de realizar essa empresa do que manter um registro fiel de minhas caminhadas solitárias e dos devaneios que as preenchem quando deixo minha mente livre por inteiro e minhas ideias seguirem suas inclinações, sem resistência e sem dificuldade. Essas horas de solidão e de meditação são as únicas do dia em que sou eu mesmo por

82 Rousseau, Jean-Jacques. Os devaneios do caminhante solitário. (Les Rêveries du Promeneur Solitaire) Tradução Júlia da Rosa Simões. Porto Alegre, RS: L\&PM, 2011.

83 idem.

84 Ao condenar o teatro na Carta a d' Alembert sobre os espetáculos (1758), os filósofos voltaram-se contra ele. Entretanto, no meio dessas disputas e acusações, Rousseau escreveu suas obras-primas: $A$ nova Heloísa (1761) - romance epistolar de um retorno à vida natural, que teve um imenso sucesso; $O$ contrato social de Emílio (1762), sendo o primeiro fruto da preocupação em esclarecer seu ideal político-educacional, e o segundo, obra pedagógica cujas ideias religiosas também foram imediatamente condenadas. Estes acontecimentos o levaram a anos de errância, e deste período são frutos: Confissões, escrito entre 1765 a 1770), e Devaneios do Caminhante Solitários, onde evocou suas lembranças.

85 ibid., p. 17. 
inteiro e pertenço a mim sem distração, sem obstáculo, e em que posso dizer de verdade que sou o que a natureza quis 86.

O tema da “sensibilidade da natureza” também pode ser identificado em A Arte de Passear, de Karl Gottlob Schelle, de 1802. Nesse livro, a atividade do passeio é relacionada com uma nova estética, segundo a qual as condições físicas do percurso realizado repercutem diretamente nas experiências vividas pelo caminhante. Para Schelle, assim como para Rousseau, a natureza é um objeto de curiosidade intelectual, fonte de imaginação e devaneio. A natureza, para “aqueles cuja sensibilidade é tocada por seu magnífico espetáculo”87, pode exercer efeitos positivos, benéficos, como a solidão pacificadora, a felicidade e o amor.

Schelle ressalta o valor das paisagens e da cultura do passeante como quesitos qualificadores dos passeios. Para ele, as caminhadas estão condicionadas aos lugares por onde se caminha e pela riqueza de espírito do passeante. A paisagem deixa de ser o resultado de um momento e passa a ser o fruto de um percurso, deixa de ser uma ideia para ser uma experiência.

O poeta Charles Baudelaire apresentou no Salão de 1846, O Herói da Vida Moderna, a estética da beleza do transitório e do efêmero a partir do marginal que vagueia pela cidade. Em o Pintor da Vida Moderna, de 1863, Baudelaire faz o elogio ao flâneur, o artista, o filósofo ou poeta que detecta a estética do novo e do choque, o espetáculo sublime do movimento infinito das multidões anônimas, que equivalem à modernidade ${ }^{88}$. Para Baudelaire "a modernidade é o transitório, o fugidio, o contingente, a metade da arte cuja outra metade é o imutável"89.

O flâneur não ocorre, como na concepção romântica, em uma paisagem natural, mas na paisagem urbana, em Paris. Walter Benjamin ao analisar a flânerie na Paris do Segundo Império, destaca a importância das ruas largas construídas por Haussmann, e das galerias, "a flânerie dificilmente poderia ter-se desenvolvido em toda a sua plenitude sem as galerias" 90 . Este era o ambiente predileto para que se pudesse fugir

\footnotetext{
86 ibid., p. 16.

87 Schelle, K. G. A Arte de Passear. São Paulo: Martins Fontes, 2001. (1802).

88 Hollevoet, Christel. Déambulations dans la ville: de la flânerie et la dérive à l'appréhension de l'espace urbain dans fluxus et l'art conceptual. Parachute, n. 68, Canada, (out., nov., dez.), 1992.

89 Baudelaire, Charles. Obras Completas II. Paris: Gallimard, 1976, p. 695.

90 Benjamin, Walter. O Flâneur. in Paris do Segundo Império. p. 34.
} 
do tédio, ou seja, em meio aos acontecimentos cotidianos da vida na cidade e em meio à multidão humana. Segundo Benjamin, a rua torna-se moradia para o flâneur, ele se sente em casa em meio às fachadas dos prédios, tanto quanto o burguês entre quatro paredes 91 .

O estado de espírito peculiar do flâneur é a solidão em meio à multidão, seu papel é o do observador, do detetive. Entretanto, diferentemente de Alan Poe ${ }^{92}$, Baudelaire não escreve nenhum romance policial, a multidão aparece em seus poemas não como o 'asilo do criminoso', mas como o refúgio do amor que foge ao poeta 93 .

O passeante de Schelle, entretanto, quando não se encontrava em meio a bosques, florestas e montanhas, encontrava-se numa pequena cidade, com "alamedas graciosamente arborizadas"94, na qual podia ser notado e de onde era possível observar “os outros flanarem”95. Por outro lado, a multidão no espaço público foi o meio fértil do qual Baudelaire se nutriu. Segundo suas próprias palavras: "Há algo mais encantador, mais fértil e emocionante como o lugar comum?"96

No início do século XX, o movimento Dadá fundado por Tristan Tzara irá compartilhar das palavras de Baudelaire. Andre Breton, Louis Aragon, Théodore Fraenkel, Francis Picabia, Georges Ribbemont-Dessaignes, entre outros, organizam uma série de excursões a lugares banais da cidade. Entre os lugares escolhidos encontra-se, por exemplo, a Igreja Saint-Julien le-Pauvre, na qual a primeira visita, realizada dia 14 de abril de 1921, foi marcada pela leitura de um Manifesto por Breton. A escolha dos lugares para as excursões dadaístas entoavam um ar de protesto, quando não eram lugares banais e inesperados, eram aqueles que de alguma forma representavam a cultura e a política que eles criticavam. Como por exemplo, as visitas agendadas, porém nunca realizadas, aos principais pontos da identidade burguesa, ao

\footnotetext{
91 ibid., p. 35.

92 Walter Benjamin em Paris do Segundo Império

93 ibid., p. 42.

94 Schelle, K. G. A Arte de Passear. São Paulo: Martins Fontes, 2001. (1802), p. 55.

95 ibid., p. 50.

96 Baudelaire, "Salon de 1859", cité dans Nadeau, Maurice, Histoire du surréalisme, Paris, Seuil, 1964, p. 28. Apud. Hollevoet, Christel. Déambulations dans La ville: de la flânerie et la dérive à l'apprehension de l'espace urbain dans fluxus et l'art conceptual. Parachute, n. 68, Canadá, out., nov., dez. 1992. (p. 21-25)
} 
Museu do Louvre, Buttes Chaumont, a Estação Saint-Lazare, Monte Petit Cadenas e o Canal de L'Ourq97.

Em 1924, os poetas Breton, Aragon, Morise e Vitrac empreendem um passeio para experimentarem as sensações físicas de uma deambulação no espaço real. O trajeto entre as cidades Blois e Romarantin foi escolhido de forma aleatória a partir de um mapa. Nesta deambulação Breton escreveu Poison Soluble, que se tornou o manifesto Surrealista. Daí em diante, as experiências da deambulação foram marcadas pela exaltação do inconsciente, dos encontros fortuitos, entendidas como uma viagem sem destino, em que afirmavam a soberania do desejo e da surpresa: "uma espécie de escritura automática no espaço real capaz de revelar as zonas inconscientes do espaço e as partes obscuras da cidade "98. Nesta deambulação surrealista, Paris é lida de maneira nova, transforma-se numa multifacetária e móvel intersecção de encontros e azares, de acontecimentos inesperados, de coincidências ilógicas que correspondem aos desejos do inconsciente ${ }^{99}$.

Os lugares narrados pelos surrealistas não são os célebres bairros turísticos, mas sim lugares populares da cidade, que apesar de menosprezados pelo público, estão envoltos em mistérios. Assim como na flânerie baudelariana, a rua também é a protagonista, juntamente com os jardins públicos, o bar e a praça. A novidade na deambulação surrealista está no fato deles introduzirem, no espaço urbano, a esfera do 'maravilhoso' a partir da imaginação.

Entretanto, são nos romances escritos por Louis Aragon (Le Paysan de Paris), André Breton (Nadja e Amor Louco) e Robert Desnos que a deambulação surrealista apresenta-se como uma importante fonte na compreensão do olhar surrealista para a cidade do início do século XX. Em Le Paysan de Paris (O Camponês de Paris), de Louis Aragon, escrito entre os anos de 1924 e 1925, e publicado em 1926, o narrador assume características de um flâneur, através da prática da deambulação urbana, mas, ao contrário do flâneur, seu olhar é de um 'estrangeiro', daquele que vem de fora analisar a cidade. O próprio título do romance sugere este olhar peculiar a partir das

\footnotetext{
97 Hollevoet, Christel. Déambulations dans La ville: de la flânerie et la dérieve à l'apprehension de l'espace urbain dans fluxus et l'art conceptual. Parachute, n. 68, Canadá, out., nov., dez. 1992. (p. 21-25). 98 Careri, F. Walkscapes: El andar como prática estética. Barcelona: Editora Gustavo Gili, 2002, p. 86.

99 Bandini, Mirella. Referentes surrealistas en las nociones de deriva y de psicogeografía del ambiente urbano situacionista. in Andreotti, Líbero e Costa, Xavier. Situacionistas: arte, política, urbanismo. Catálogo de Exposição, Museu de Arte Contemporânea, Barcelona, 1996.
} 
duas figuras antagônicas, a do camponês, o homem simples da vida no campo e a figura da metrópole moderna.

Le Paysan de Paris é composto de quatro capítulos, Préface à une mythologie moderne, Le passage de l'Opéra, Le sentiment de la nature au Buttes-Chaumont e Le songe du paysan. Em Le passage de L'Opéra observa-se o elogio à 'beleza efêmera da atmosfera urbana', aproximando-se do elogio à metrópole realizado por Baudelaire. As passagens, no romance de Aragon, são ícones da vida moderna e "santuário do transitório"100. Como já comentado, essa mesma imagem a respeito das passagens, também foi explorada por Walter Benjamin em Le livre des Passages (1927-40).

A busca psicológica pelo entorno urbano, com percursos nômades pela cidade, fará parte também do Letrismo (1946), grupo que está na origem da Internacional Situacionista. Em 1953, o então letrista Ivan Chtchegloff escreveu Formulário para um novo urbanismo, publicado anos depois, em 1958, no primeiro boletim da Internationale Situationiste. Nesse texto, Ivan Chtchegloff, com o pseudônimo Gilles Ivain, apresenta uma visão 'surrealista' sobre a cidade, atribuindo à arquitetura a responsabilidade de transformar as concepções de tempo e de espaço, a partir de uma estrutura maleável, transformável segundo os desejos de seus habitantes101

Vivemos numa paisagem fechada cujos pontos de referência remetem sempre ao passado. Certos ângulos moventes, certas perspectivas fugazes permitem-nos entrever concepções originais do espaço, mas essa visão parece parcelar. É preciso procurá-la nos lugares mágicos dos contos folclóricos e dos textos surrealistas: castelos, muros intermináveis, barezinhos esquecidos, caverna do mamute, espelho dos cassinos.

(...) o telhado de vidro deixa ver as estrelas e a chuva. A casa móvel gira com o sol. As paredes de correr permitem que a vegetação

100 Hollevoet, Christel. Déambulations dans La ville: de la flânerie et la dérieve à l'apprehension de l'espace urbain dans fluxus et l'art conceptual. Parachute, n. 68, Canadá, out., nov., dez. 1992. (p. 21-25). 101 Levin, T. Y. Geopolítica de la hibernación: la deriva del urbanismo situacionista. In Andreotti, L e Costa, X. (org.) Situacionistas: arte, política, urbanismo. Situationists: art, politics, urbanismo. Barcelona: ACTAR, 1996. p. 116. 
se misture a vida. Montada sobre rodas, uma casa pode ir pela manhã até o mar e voltar à noite para a mata102.

As ideias de Chtchegloff sobre cidade iam ao encontro da Teoria da Deriva formulada por Guy Debord em 1956 e da psicogeografia. A deriva situacionista era caracterizada como uma “técnica de passagem rápida por ambiências variadas”, seu conceito está indissoluvelmente ligado ao reconhecimento de efeitos de natureza psicogeográfica e à afirmação de um comportamento lúdico-construtivo, o que o torna absolutamente oposto às tradicionais noções de viagem e de passeio"103. O termo psicogeografia, é um neologismo criado pelos situacionistas ${ }^{104}$, definido como um "estudo dos efeitos exatos do meio geográfico, conscientemente planejado ou não, que agem diretamente sobre o comportamento afetivo dos indivíduos”105. Ou seja, a geografia trata da ação determinante das forças naturais gerais como a composição do solo e as condicionantes climáticas sobre as estruturas econômicas de uma sociedade, enquanto a psicogeografia trata das influências do meio geográfico sobre o comportamento e os sentimentos humanos.

Segundo o situacionista Asger Jorn, no texto Esboço de descrição psicogeográfica dos Halles de Paris, publicado no segundo boletim da IS, em dezembro de 1958, a psicogeografia apresenta-se como a ficção científica do urbanismo, enquanto a deriva, um modo de comportamento experimental da sociedade urbana. A deriva psicogeográfica seria, então, um modo de ação e de conhecimento.

Ainda nesse texto, Jorn esclarece que os recursos convencionais, como a leitura de fotos aéreas e de mapas, o estudo de estatísticas, de gráficos ou de resultados de pesquisas sociológicas não possuem o lado ativo e direto que possui a deriva experimental. Para os situacionistas é preciso uma intervenção “direta, efetiva, que leve, após os indispensáveis estudos preliminares - e nesse ponto a psicogeografia será de grande importância -, a instaurar ambiências, situacionistas, cujas características essenciais são a curta duração e a mudança constante”. Os situacionistas ainda

102 Ivain, Gilles. (Chtchegloff). O urbanismo Unitário no fim dos anos 1950. In Boletim Internacional Situacionista, $n^{\circ}$ 3, dezembro de 1959.

103 IS, Definições. In Boletim Internacional Situacionista, nº 1, junho de 1958.

104 McDonough, Thomas. La Deriva y el París Situacionista. in Libero, A. e Costa, X. Situacionistas: Arte, Política, Urbanismo. Situationist: Art, Politics, Urbanism. Museu d'Art Contemporani de Barcelona, Barcelo, 1996. p. 55.

105 IS, Definições. In Boletim Internacional Situacionista, nº 1, junho de 1958. 
propunham a construção de mapas psicogeográficos, ou seja, o registro dessa apreensão psicológica dos espaços da cidade.

A cidade, segundo os situacionistas, é um verdadeiro laboratório e objeto de investigação. Eles substituem a ênfase dada ao inconsciente e ao acaso da deambulação surrealista adotando a deriva como um método objetivo de exploração. Os situacionistas resgatam as primeiras intenções revolucionárias dos surrealistas, em particular o projeto de inclusão da arte na vida cotidiana. Em contrapartida, criticam radicalmente a ideia de uma riqueza infinita da imaginação inconsciente: "Bem sabemos que a imaginação inconsciente é pobre, que a escritura automática é monótona... e tudo isso levou o grupo ao ocultismo". Ao contrário da aleatoriedade da errância surrealista, os situacionistas propõem a construção de situações que resgatam o homo ludens de Huizinga ${ }^{106}$, estabelecendo um grande jogo de desejos que redefine o papel do público, de passivo e figurante a vivificador. Os situacionistas defendem a ideia de jogo no processo de construção de situações no momento que, ao atuar diretamente nas relações sociais, podem proporcionar uma nova vivência, com a eliminação da competição e da monotonia da vida ${ }^{107}$. Desta forma, a vida real, antes lugar do tédio e da insignificância, e vida imaginária, lugar da maravilha e do significado, que tinham sido aceitos e criados pelos surrealistas, são completamente revirados: é a própria realidade que pode tornar-se maravilhosa 108.

Segundo Cristina Freire, "se o Surrealismo propunha tornar familiar o estranho, confiando para isso no acaso, os Situacionistas preocupavam-se em tornar significativos certos setores da cidade"109, buscando reconhecer as diferentes cargas afetivas que distinguissem os diversos pontos da cidade. A deriva para os situacionistas foi acompanhada por uma análise sociológica e política que expressa uma crítica da vida cotidiana da cidade burguesa110. Está aí uma característica importante para diferenciar o flâneur, no século XIX e as práticas do andar da década de 1960, com a deriva situacionista. Enquanto o flâneur tem como característica principal o prazer de olhar, apropriando-se dos objetos pelo olhar e pela fantasia, via

106 Huizinga, J. Homo Ludens: o jogo como elemento da cultura. SP: Perspectiva, 1971.

107 IS, Contribuição para uma definição situacionista de jogo.

108 Perniola, Mario. Os Situacionistas: o Movimento que Profetizou a "Sociedade do Espetáculo". São Paulo: Annablume, 2009. p. 18.

109 Freire, C. Além dos Mapas: os monumentos no imaginário urbano contemporâneo. SP: SESC: Annablume, 1997, p. 68.

110 Careri, Francesco. Constant, New Babylon, Una Città nomade. Testo \& Immagine, 2001, p. 33. 
contemplação, os situacionistas propõem a construção de situações, onde os próprios elementos da cidade poderiam reconstruir a realidade.

Essas operações no espaço urbano são marcadas por um processo no qual a cidade é tomada como palco de performances efêmeras, de instalações provisórias e de esculturas específicas. Na década de sessenta o grupo Fluxus, fundado por George Maciunas, toma também a rua como solução para os problemas da arte confinada nos museus. Fazem parte de suas atividades os itinerários e as excursões pela cidade, os happenings. O espírito de suas excursões aproximam-se das realizadas pelos dadaístas, seus diagramas evocam os mapas psicogeográficos de Debord, assim como os happenings, emergem como crítica à passividade do espectador similar à crítica debordiana e às práticas situacionistas de intervenção, o que inclui, portanto, a adoção a um comportamento experimental, o gesto provocativo e a abordagem lúdica inspirada na ideia de jogo de Johan Huizinga ${ }^{111}$. Map Piece (1964) de Yoko Ono exemplifica esta abordagem lúdica imersa na vida cotidiana:

Desenhe um mapa imaginário. Coloque uma marca de um alvo aonde queira ir. Vá andando em uma rua de verdade de acordo com seu mapa. Se não há uma rua onde deveria haver de acordo com seu mapa, faça uma colocando de lado os obstáculos. Quando você atingir o alvo, pergunte o nome da cidade e dê flores para a primeira pessoa que encontrar. O mapa deve ser seguido estritamente, ou o evento tem que ser cancelado. Peça a seus amigos para desenharem mapas. Dê mapas a seus amigos.

Atualmente o grupo italiano Stalker realiza 'deambulações' urbanas, ligados à arquitetura e ao urbanismo procuram realizar, a partir da caminhada pela cidade, as leituras das cidades como se fossem grandes mapas cognitivos atualizados continuamente através do seu "atravessamento". Liderado pelo arquiteto italiano Franceso Careri, o grupo considera a intervenção no espaço como um ato de criação, onde o que é mais importante é a forma como o espaço é percebido e não o modo como ele "é” na realidade. O próprio grupo Stalker coloca-se em sintonia com as ideias situacionistas quando afirma compartilhar do gosto pelas investigações urbanas,

111 Hollevoet, Christel. Déambulations dans La ville: de la flânerie et la dérieve à l'apprehension de l'espace urbain dans fluxus et l'art conceptual. Parachute, n. 68, Canadá, out., nov., dez. 1992. (p. 21-25). 
da sensibilidade para com as transformações contemporâneas e para com os sintomas característicos de uma sociedade em processo de mudança.

\subsection{A Cidade e os Mapas}

Maps always lie, the true places never are there. Moby Dick, Herman Melville.

Assim como a descrição, precisão e cálculo da cartografia convencional, encontramos mapas que são construídos a partir de um interesse numa outra ordem, descolados da realidade, mas não inteiramente, pois apresentam resultados advindos da própria vivência e narrativa dos lugares. Esses mapas apresentam uma experiência do espaço que se desdobra além do espaço físico, comportando direções afetivas numa cartografia subjetiva.

A psicogeografia, como já definida, ampara este tipo de apreensão e descrição do espaço. Em O Urbanismo Unitário no fim dos anos 1950, texto de 1959, os situacionistas citam a Carte du Pays de Tendre, representação imaginária da Terra do Amor. A Carte de Tendre data do século XVII, realizada pela francesa Madeleine Scudére, e compõe o romance Clélie, histoire romaine, escrito por Madeleine entre 1654-1660, composto de 10 volumes. Em seu mapa, Madeleine apresenta os lugares como físicos e emocionais. Sua geografia é composta por mares, rios, lagos, árvores, pontes e habitações. Observa-se regiões denominadas Generosidade, Obediência, Esquecimento, Ternura, entre outras. Estas encontram-se abertas, sujeitas a uma infinidade de trajetos, enquanto a única região fechada é denominada Lago da Indiferença. Esta região que abriga o sentimento que representa justamente o encerrar das emoções, parece também sugerir o fim da viagem.

Entretanto, enquanto a Carte de Tendre prevalece uma narrativa imaginária, os mapas situacionistas são definidos a partir de uma narrativa mais realística dos lugares a partir de um levantamento de localidades urbanas concretas. Em 1955, Guy Debord, em Introdução a uma Crítica da Geografia Urbana, escrevia: "hoje, o principal 
problema que o urbanismo tem a resolver consiste em melhorar o tráfego do crescente número de veículos automotores. É possível que um urbanismo futuro se dedique a construções, igualmente utilitárias, que levem em consideração as potencialidades psicogeográficas".

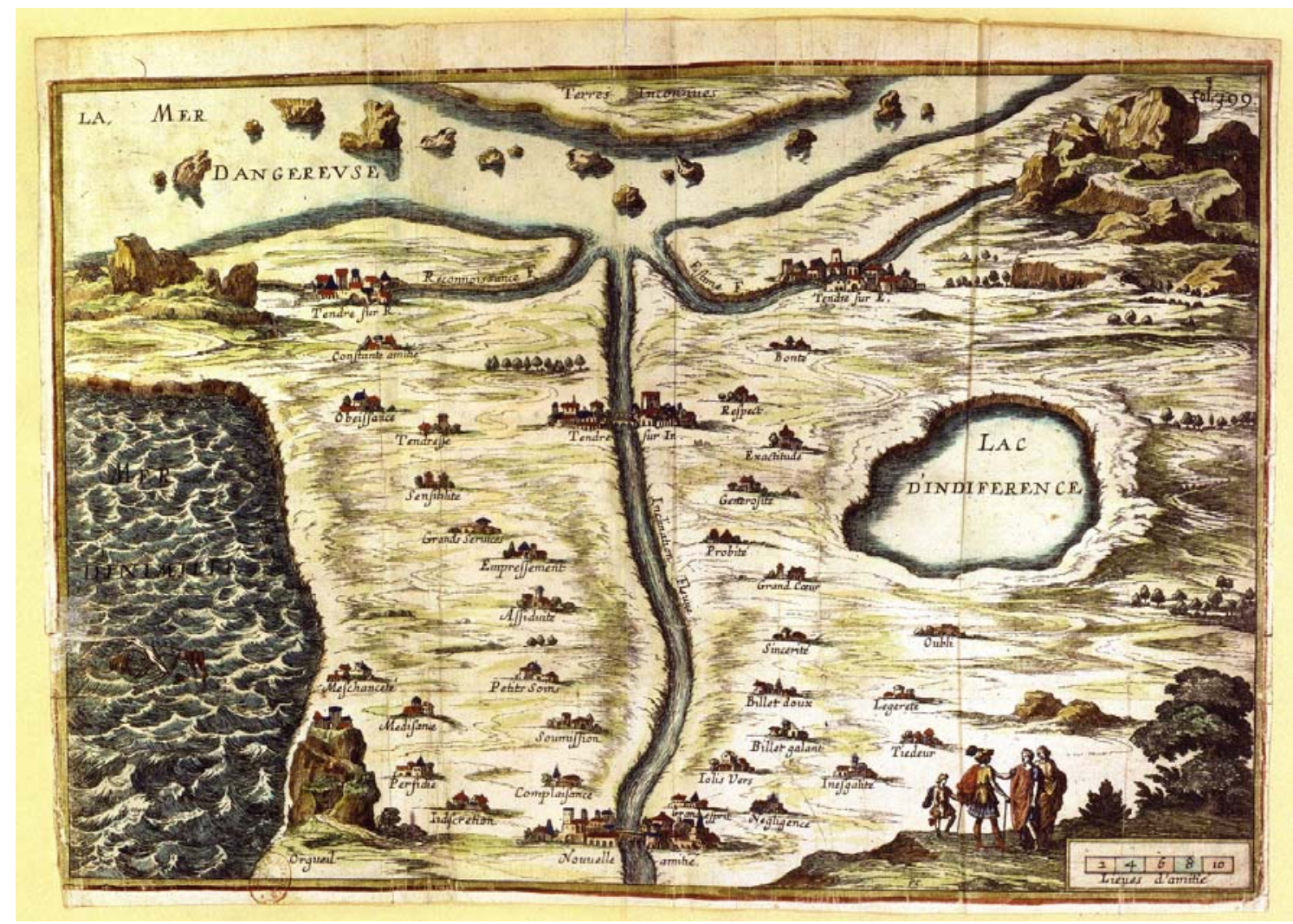

Figura 1 Carte du Pays de Tendre, Madeleine Scudére. in http://upload.wikimedia.org/wikipedia/commons/6/6b/Carte_du_tendre_300dpi.jpg

Os situacionistas de forma geral encararam a realização de derivas psicogeográficas pelos espaços das cidades como forma de acusar o urbanismo funcionalista de monótono e repetitivo. Essa crítica ao planejamento urbano moderno foi tensionada ainda pelo contexto pós II Guerra Mundial. Segundo Constant, tanto os bairros antigos quanto os modernos passaram a apresentar uma "ambiência morna e estéril": nos bairros antigos as ruas transformaram-se em autoestradas, os lazeres foram comercializados e deturpados pelo turismo, enquanto os bairros recém construídos limitaram-se ao trânsito de carros e ao conforto residencial, ou seja, esvaziados de qualquer preocupação lúdica112.

112 Nieuwenhuys, Constant Outra Cidade para outra Vida. Revista Internacional Situacionista, $\mathrm{n}^{\circ}$ 3, dezembro de 1959. 
Desta forma, a deriva, somada ao método psicogeográfico, busca resignificar os espaços da cidade a partir de uma geografia afetiva e subjetiva. As diferentes ambiências psíquicas provocadas pelas deambulações deveriam também ser registradas, seja por fotografias, filmagens ${ }^{113}$, fotocolagens, como pela elaboração de mapas.

Esta análise 'psicogeográfica' da cidade já estava presente nas deambulações surrealistas. André Breton, em La Clé des Champs, em 1953, apresenta os lugares da cidade a partir dos efeitos de 'atração' ou 'repulsão' que cada um deles desperta na sensibilidade humana. Breton chega a afirmar que a partir de uma deambulação urbana despretensiosa é possível identificar zonas de bem estar e de mal estar que se alternam durante o percurso. Breton constrói a partir de suas descrições 'psicogeográficas' um mapa imaginário e individual da cidade na qual os lugares aprazíveis estariam marcados em branco e os que deveriam ser evitados, em preto, enquanto todos os outros seriam na cor cinza, representando as zonas em que a atração e a repulsão se alternam $^{114}$.

Este espírito, que procura uma leitura psicológica dos espaços da cidade, aparece no Pós II Guerra Mundial associado à própria destruição das cidades, e ao impacto psíquico e de desorientação desse contexto. Deste processo, desencadeia uma série de práticas artísticas que busca, justamente por conta da perda de referências, traçar territórios a partir de uma geografia subjetiva. Vê-se surgir tanto no cinema, quanto nas artes plásticas, a temática da deambulação urbana, apresentando itinerários emocionais, como em Hiroshima Mon Amour, de 1959, dirigida pelo cineasta francojaponês Alain Resnais. Neste filme, Resnais propõe uma leitura psicogeográfica da cidade recém destruída pela guerra. Essa leitura psicogeográfica do espaço da cidade é fundamental para a amarração da complexa narrativa em que se desenvolve seus personagens. Hiroshima encontra-se imersa numa atmosfera sufocante de tristeza e da memória recente de uma bomba atômica que havia destruído tudo. Sua história dramática divide-se entre a memória recente do passado trágico e a possibilidade do esquecimento, entrelaçada ao próprio drama existencial vivido pelas personagens, uma

113 Algumas derivas filmadas chegaram a aparecer em filmes de Debord, como por exemplo em Sur le passage de quelques personnes à travers une assez courte unité de temps, de 1959.

114 Bandini, Mirella. Referentes surrealistas en las nociones de deriva y de psicogeografía del ambiente urbano situacionista. in Andreotti, Líbero e Costa, Xavier. Situacionistas: arte, política, urbanismo. Catálogo de Exposição, Museu de Arte Contemporânea, Barcelona, 1996. p. 42-43. 
atriz francesa e um arquiteto japonês, que se conhecem em Hiroshima no final dos anos 50 .

O drama da atriz francesa gira em torno de seu passado recente, ela esforça-se para esquecer que se envolvera com um soldado alemão em plena II Guerra Mundial, quando ainda era adolescente e morava na cidade de Nevers. Agora vivendo em Hiroshima, ela busca esquecer este passado, libertando-se da culpa e das lembranças que tanto a torturam. Como atriz, seu processo de elaboração do trauma dá-se a partir da mimese. Enquanto Hiroshima, como ela denomina o próprio arquiteto, vive o drama da destruição recente que abalou sua cidade, ele é exatamente um sobrevivente da bomba, e como arquiteto, busca a construção, o novo. Em ambos, os conflitos do passado se manifestam no trauma e na memória, e a impossibilidade do esquecimento os legitimam em suas identidades, condenando-os, por fim, ao passado e à memória.

O filme chamou a atenção dos próprios situacionistas que dedicaram uma seção do $\mathrm{n}^{\circ} 3$ de seus Boletins comentando a originalidade do então recém lançado Hiroshima Mon Amour. Em texto intitulado Le Cinéma Aprés Alain Resnais, comentam, entre outros aspectos, a importância do som e da palavra no desenrolar da história, mesmo em detrimento da imagem, uma vez que observam que o sentido da imagem dá-se por conta do discurso oral, como é possível observar ao longo do travelling pelas ruas na primeira sequência do filme ${ }^{115}$.

Outro exemplo da descrição psicogeográfica da cidade no cinema pode ser observado em Asas do Desejo (Der Himmel über Berlin), dirigido por Wim Wenders, em 1988. Neste filme, dois anjos são enviados à Terra para deambularem pela cidade de Berlim, recém destruída.

Nesse contexto antes da queda do Muro que separava a Alemanha em duas, a experiência urbana apresentava-se limitada, marcada pelo isolamento cada vez maior dos indivíduos e pela pobreza dos espaços públicos: “Em Berlim, não é possível se perder, pois qualquer caminho vai dar no Muro”, reflete um anjo. A psicogeografia deste espaço urbano revela-se na nostalgia de um dos personagens em sua busca infrutífera pela Potsdamer Platz, praça outrora cheia de vida, que havia sido totalmente devastada pela guerra.

A experiência urbana desapaixonante apresenta-se no filme em imagens pretoe-branco, intercaladas por pequenas cenas coloridas (que indicam o processo no qual o

115 IS, Boletim no 3. Le Cinéma Aprés Alain Resnais. Dezembro de 1959. 
anjo vai paulatinamente se apaixonando pela vida dos homens), até o final, quando rendido à paixão humana, passa a ver o mundo colorido e o filme explode em cores.

No campo das artes plásticas nota-se também o surgimento de uma série de leituras psicogeográficas retratadas a partir de mapas. Uma exposição que ocorreu em 1994, no Museu de Arte Moderna de Nova Iorque, denominada Mapping116, reuniu mapas construídos a partir de visões bastante particulares e subjetivas dos espaços. Entre os 30 mapas selecionados ${ }^{117}$, de diferentes artistas e nacionalidades, encontra-se Discours sur les passions de l'amour, de 1957, produzido por Guy Debord.

Discours sur les Passions de L'amour como o próprio título sugere, diz respeito aos imperativos do prazer em detrimento da tendência reificadora do espaço e dos meios físicos. Neste mapa, Debord apresenta a cidade de Paris a partir de um plano totalmente fragmentado, cada parte encontra-se em preto e branco, ligadas entre si por setas vermelhas, que sugerem direções e percursos variados. A lógica que estrutura as partes e as possíveis relações e trajetos é a afetiva, oriunda mesmo da relação direta entre a cidade e a vida cotidiana.

Nessa mesma série encontra-se The Naked City: illustration de l'hypothése des plaques tournantes en psychogeographique, realizado por Guy Debord um ano depois, em 1958. O título do mapa foi inspirado em um film noir de mesmo nome e o subtítulo faz alusão às placas giratórias (plaques tournantes) e manivelas ferroviárias

116 Catálogo de Exposição Mapping. Organizada por Robert Storr. The Museum of Art, New York, 1994.

117 Participaram da Exposição: Mappa del mondo (1989) de Alighiero e Boesti, Map (1963) de Jasper Johns, Japão (1972) de Waltércio Caldas, Portland (1992) de Greg Colson, Mapa de Lopo Homem (1992) de Adriana Varejão, Garden (A World Model) (1973), de Öyvind Fahlström, The Sound of 25 Km., Holland (1969) de Jan Dibbets, My City Was Gone (1991-92) de Heide Fasnacht, Couting 18,089 Dots, Hasmish Fulton, 1993, Discurs sur les passions de l'amour, de Guy Debord, 1957, La Germania, Luciano Fabro, 1984, United Shapes of America III (Maps of the U.S. Drawn by Las Vegas Teenagers), Kim Dingle, 1994, Three Attempts to Understand van Gogh's Ear in Terms of the Map of Africa, (1980), David Ireland, Untitled, (1980), Kim Jones, Untitled (1988), John Miller, Buried Poem \#2 (20 de Abril de 1971), (1971), Nancy Holt, Montes Apenninus Region of the Moon, (1972), Nancy Graves, Fields on a Map, (1950), Ellsworth Kelly, Portable World (1986), Annette Lemieux, Photograph of Part of Manhattan with the Area Between the John Weber Gallery, the Former Dwan Gallery, and Sol LeWitt's Residence Cut Out (R745), (1977) Sol LeWitt, Planétaire (Bleu) (1961), Yves Klein, Untlited (1992), Guilhermo Kuitca, Soft Manhattan \#I (Postal Zones) (1966), Claes Oldenburg, The Great Bear (1992), Simon Patterson, Columbus Making Ripples (1993) Miguel Angel Ríos, Map of Clear Broken Glass Strips (Atlantis) (1966), Robert Smithson, A Seven Day Circle of Ground, Seven Days Walking Within an Imaginary Circle 5 1/2 Miles Wide. Dartmoor, England 1984 (1984) Richard Long, Parallel Grid Proposal for Dugway Proving Ground Headquarters (1968), Adrian Piper, (No title) (1990), Raymond Pettibon, Untitled ("fig. I fig. 0 fig. A fig. 2 fig. 12") (1972), Marcel Broodthaers. 
responsáveis pela mudança de direção dos trens, que representavam as diferentes opções de caminhos a serem tomados nas derivas ${ }^{118}$.

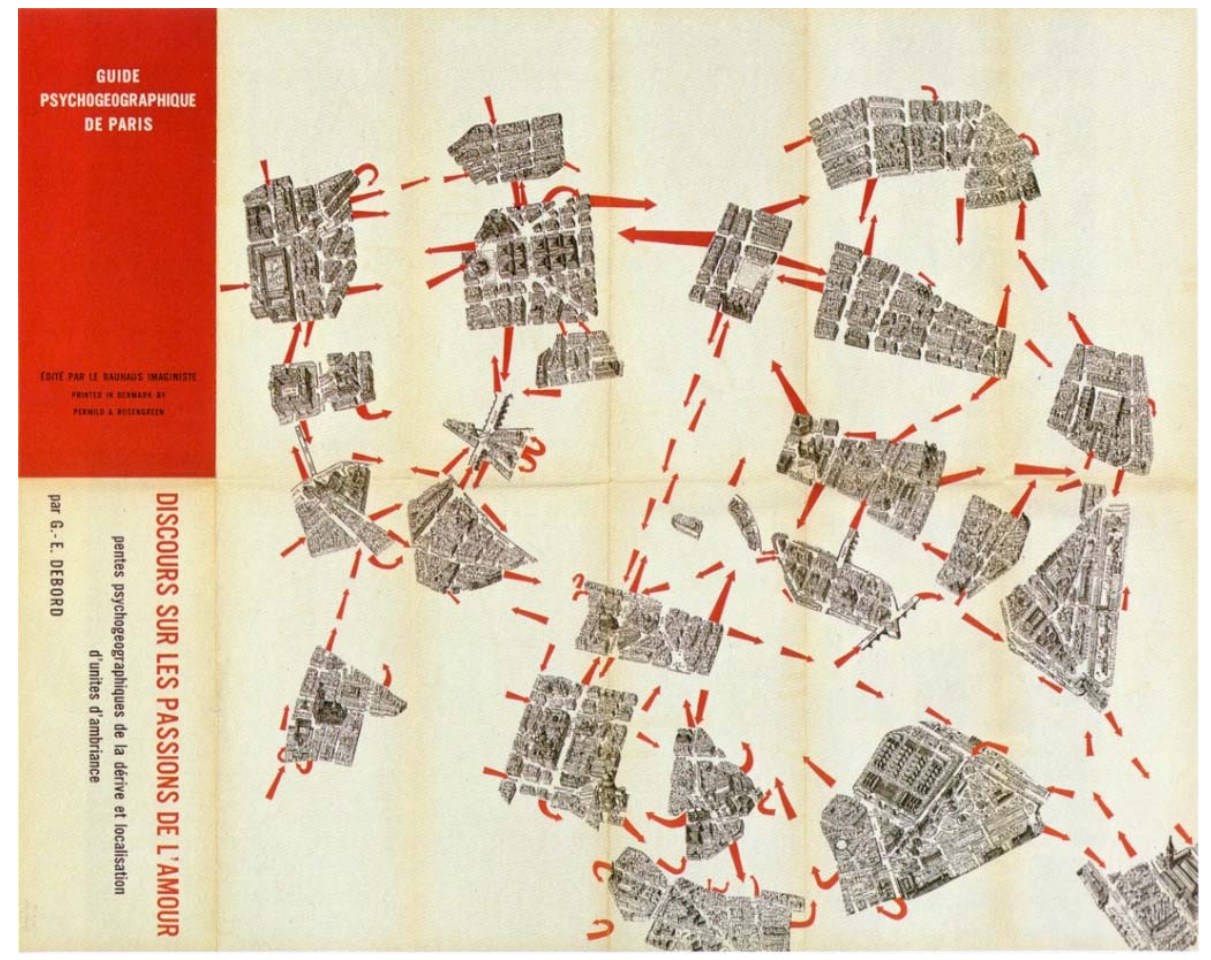

Figura 2 Discours Sur Les Passiones de L'Amour. Guy Debord, 1957.

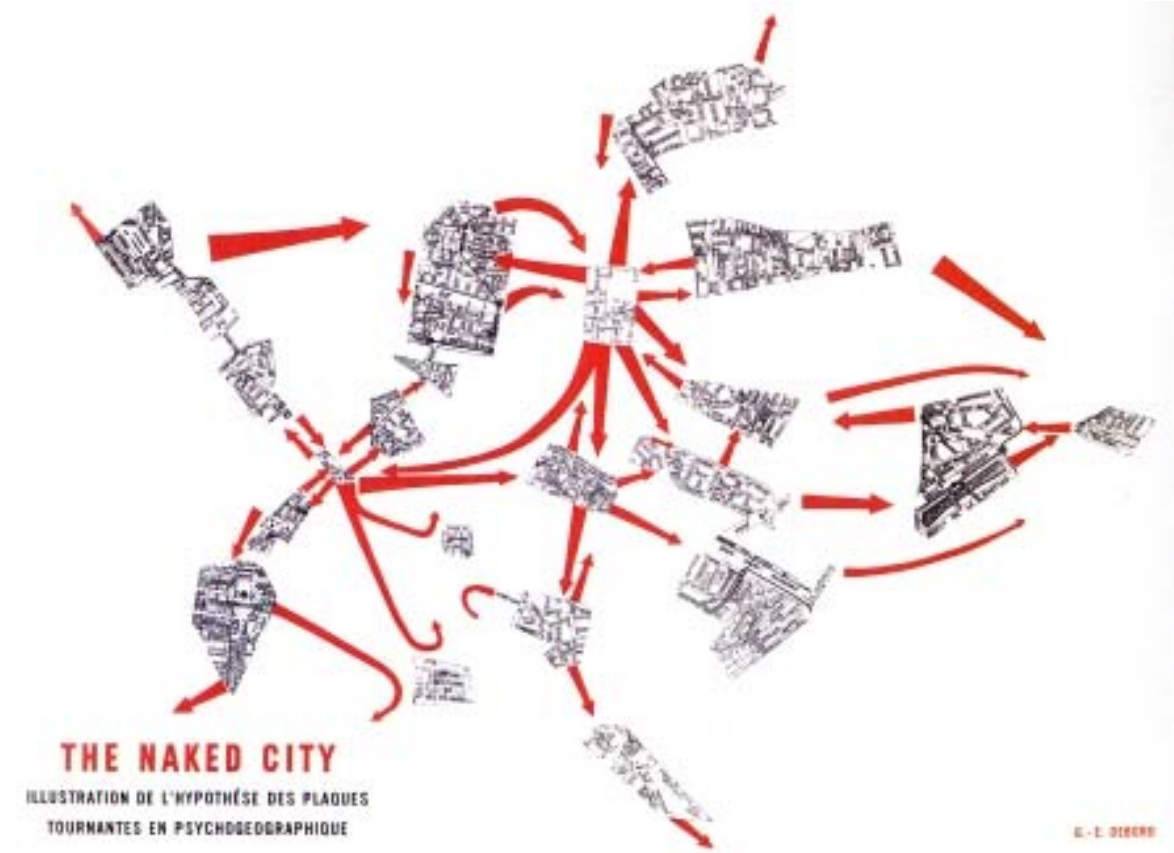

Figura 3 The Naked City. Guy Debord, 1958.

118 Jaques, Paola Berenstein (org.). Internacional Situacionista; Apologia da Deriva, escritos situacionistas sobre a cidade. Rio de Janeiro: Casa da Palavra, 2003, p. 23. 
O filme Naked City, de 1948, dirigido por Jules Dassin e produzido por Mark Hellinger, apresenta a cidade de Nova Iorque como o próprio cenário. Hellinger inspirou sua produção nas fotografias urbanas realizadas por Arthur Felling, um fotógrafo policial que fotografava cenas reais de Nova Iorque, e que foram publicadas num livro intitulado Naked City. No filme, o espaço psicogeográfico é delineado ao mesmo tempo pela natureza pulsante e pela diversidade que caracterizam Nova Iorque, bem como pelo espírito nostálgico de uma cidade que, principalmente por conta das transformações, não mais existe.

Thomas McDonough identifica na cartografia situacionista uma relação direta com a etnografia urbana do pós-guerra, e a influência do sociólogo urbano Paul-Henry Chombart de Lauwe. De fato, os situacionistas citam, logo no primeiro Boletim, Paris et l'agglomération parisienne, publicado por Lauwe em 1952, e seu diagrama em que apresenta um levantamento de todos os trajetos efetuados durante um ano por uma estudante que morava no XVIéme arrondissement de Paris.

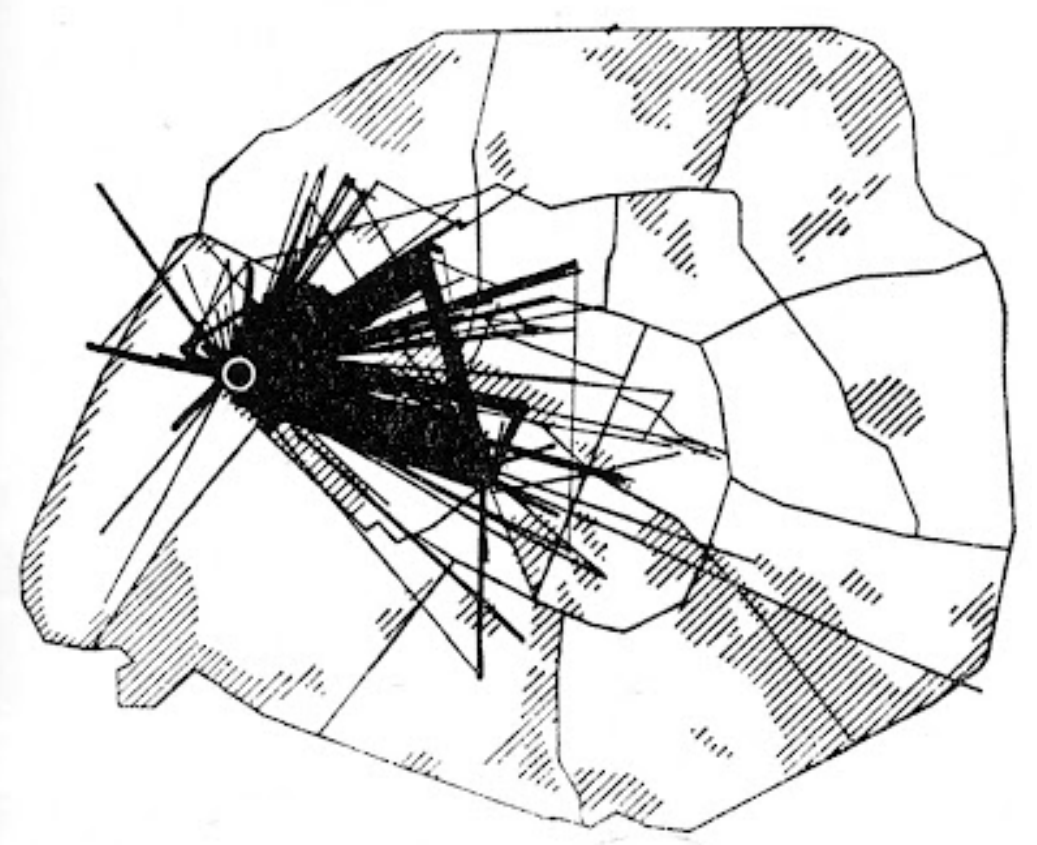

Figura 4 Paris et l'agglomération parisienne, Paul-Henry Chombart de Lauwe, 1952.

Ainda encontramos a cidade como tema nos mapas de Guilhermo Kuitca. Em obra sem título de 1992, Zurique aparece vista do alto, sob névoas, sedutora e fria, 
fantástica e um pouco triste, que guarda ao invés de propagar seus segredos ${ }^{119}$. A cidade de Manhattan aparece na obra de Sol LeWitt, Photograph of Part of Manhattan with the Area Between the John Weber Gallery, the Former Dwan Gallery, and Sol LeWitt's Residence de 1977. Nesta obra, ao contrário de Kuitca que se perde "em sua teia intrincada", LeWitt a usa para compor formas finamente bem definidas, refletindo um controle, mesmo que parcial, na malha labiríntica da cidade.

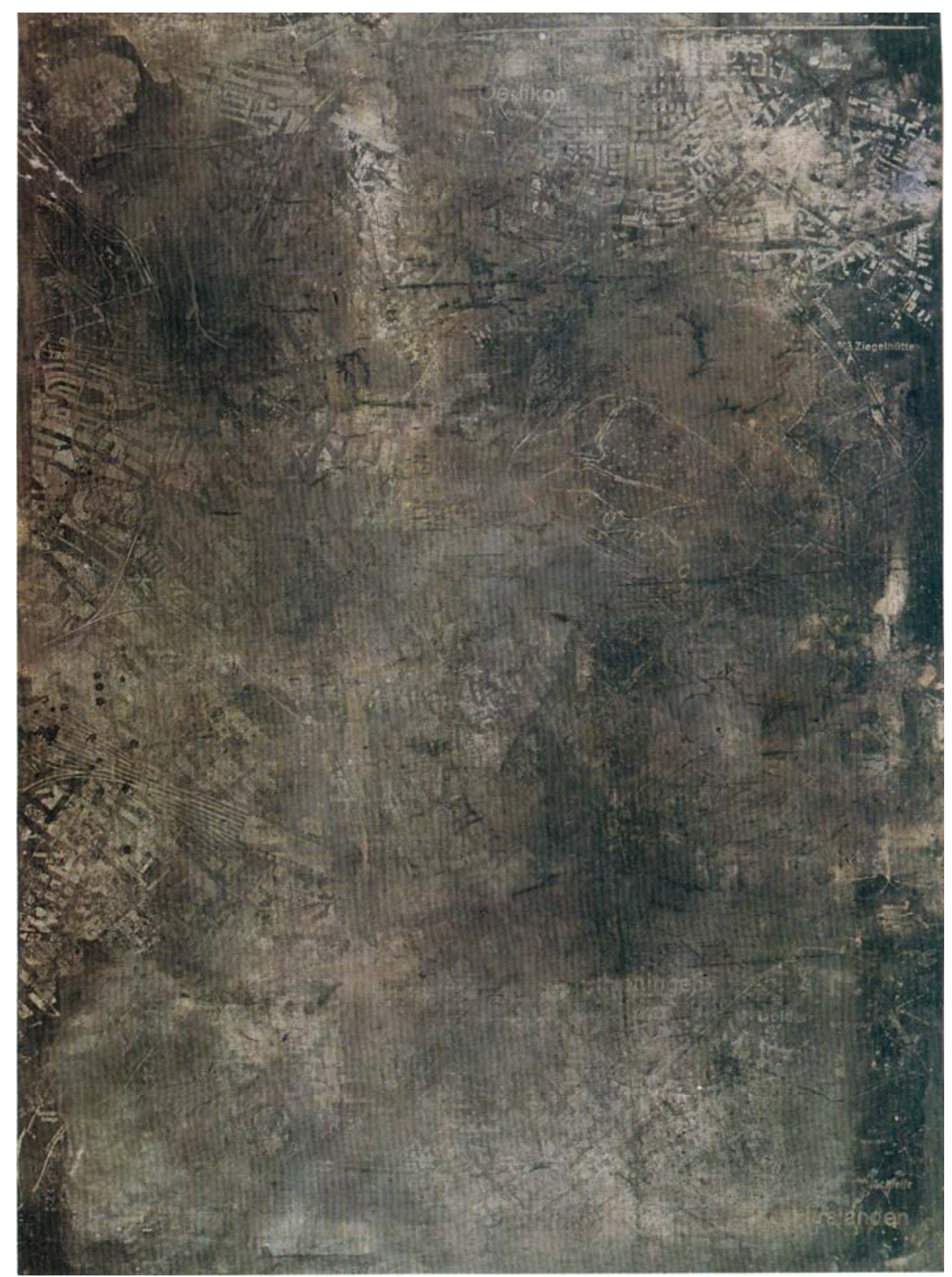

Figura 5 Guilhermo Kuitica. s/t, 1992.

119 Catálogo de Exposição Mapping. Organizada por Robert Storr. The Museum of Art, New York, 1994. p. 15. 
Também encontram-se mapas construídos a partir de outras leituras do espaço geográfico, que se distanciam sobremaneira de uma etnografia urbana do pós-guerra ou de estudos de cidades específicas, como no caso da série de mapas realizados pelo brasileiro Waltercio Caldas, em 1972, Japão, África e Índia. Estas obras refere-se à terras distantes, incógnitas, que surgem em imagens incompletas, envoltas de mistérios. Waltercio Caldas destaca países e continentes que apesar de nomes familiares, possuem uma realidade muito distante, que escapa à compreensão imaginativa dos europeus e americanos, como observou Robert Storr ${ }^{120}$. Nos três casos, Waltercio "citando as margens franco-governadas (sic) e letras elegante da cartografia clássica", construiu com esses pequenos pontos dispersos aleatoriamente num fundo branco, uma silhueta imprecisa, sem contornos, criando "um jogo insolúvel de ligar pontos"121

120 Robert Storr. (org.) Catálogo de Exposição Mapping. Organizada por Robert Storr. The Museum of Art, New York, 1994. p. 15.

121 idem. 


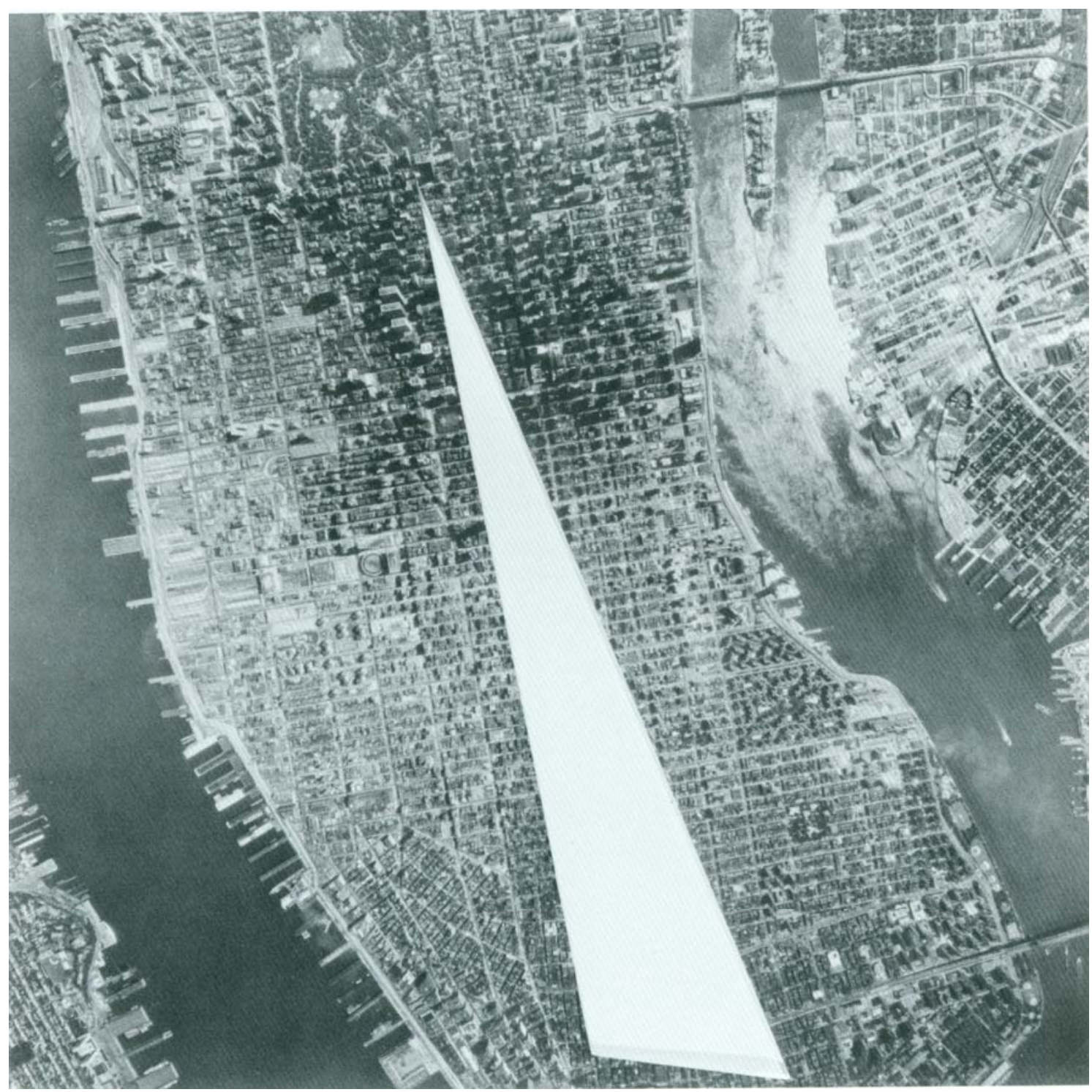

Figura 6 Sol LeWitt, Photograph of Part of Manhattan with the Area Between the John Weber Gallery, the Former Dwan Gallery, and Sol LeWitt's Residence de 1977. 


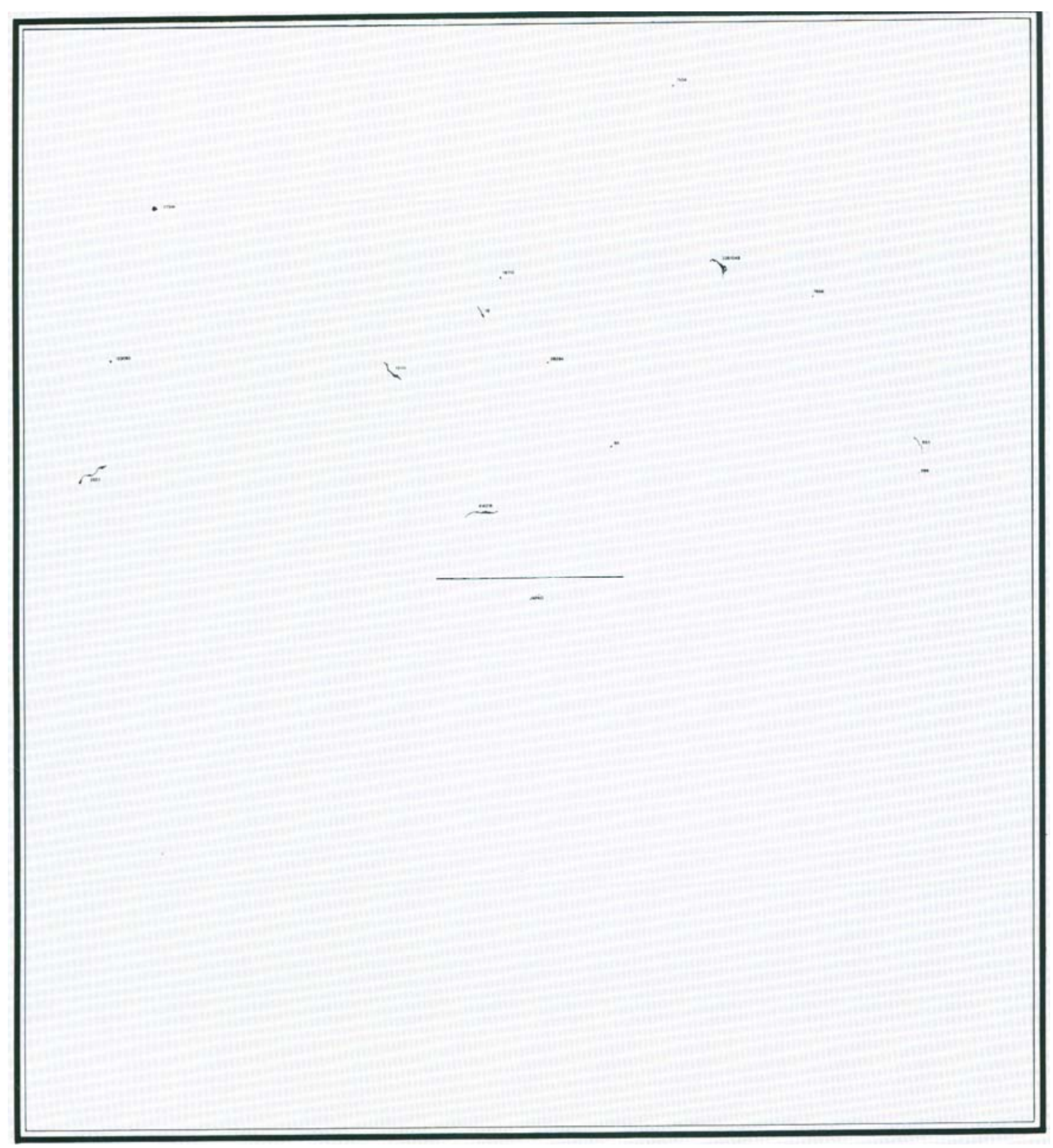

Figura 7 Waltercio Caldas. Japão, 1972.

Observa-se que nestas leituras psicogeográficas a cidade deixa de ser apenas cenário, dotada de espaços espetacularizados, descarnados, para funcionar como um corpo vivo, que permite uma série de experimentações e vivências. No próximo capítulo discute-se a deambulação urbana na trajetória artística de Hélio Oiticica. A deambulação empreendida por Hélio Oiticica relaciona-se à abordagem lúdica, que também considera os espaços da cidade em suas ambiências singulares, tomando o campo urbano como um labirinto topográfico. Seus Penetráveis labirínticos, como resultado de seu delirium ambulatorium pela cidade, são considerados "um tipo de mapa", como ele próprio chega a afirmar em entrevista ao crítico de arte Guy Brett em 
1969, são apreensões psicogeográficas da cidade real, são também uma resposta à cidade formal, refletem a "desorganização das coisas orgânicas como os caminhos que se formam nas florestas ou jardins, ou a maneira como as favelas vão surgindo como sábia utilização dos espaços"122.

122 Salomão, Wally. Hélio Oiticica. Qual é o Parangolé? 


\section{A Deambulação Poética de Hélio Oiticica}

Hélio Oiticica costumava dizer que sua relação com a cidade nasceu enquanto bem jovem, quando saía, preferencialmente à noite, deambulando pelas ruas do Rio de Janeiro. Seus destinos preferidos nada tinham a ver com aqueles badalados pela elite carioca, passando longe de Ipanema e Copacabana, buscando antes "conhecer gente de rua principalmente turmas da Central do Brasil"123. Com facilidade de fazer amizades, Hélio gostava de ambientes com "gente vagabunda, sem nada o que fazer, sentado, bebendo cerveja"124. Em 1963, foi levado pelo amigo e escultor Fernando Jackson Ribeiro à favela da Mangueira, um espaço labiríntico em todo propício às deambulações que então empreendia pela cidade. Seu envolvimento foi imediato: "lá encontrei gente inteligente e livre da parafernália intelectual de Ipanema"125. Para aquele "jovem apolíneo" e até um pouco "pedante", como definiu a amiga Lygia Pape, o encontro com a cultura da favela representou, definitivamente, a "derrubada de preconceitos sociais, das barreiras de grupos, classes e etc" 126 .

Daí em diante, Hélio passou a frequentar o morro e estreitar relações com seus moradores. Era a descoberta também da "conexão entre o coletivo e a expressão individual", (...) "ou seja, o desconhecimento de níveis abstratos, de "camadas" sociais, para uma compreensão de uma totalidade"127. Tornou-se amigo de Rose, esposa do então diretor da Mangueira, irmã de Renô, morto por um "golpe de tambor, perto do Museu de Arte Moderna", logo após ter sido solto da prisão, amigo de Miguelzinho da Lapa, Gerônimo, "um dos maiores passistas de Mangueira", de Cara de Cavalo, a quem prestou homenagem em um Bólide, depois dele ter sido morto em uma

123 Oiticica, Hélio. Um mito vadio. Entrevista concedida a Jary Cardoso, em que estiveram presentes também Luís Fernando Guimarães, que tinha sido do grupo Oficina e o músico e compositor Jards Macalé. In Folhetim. São Paulo, domingo, 5 de novembro de 1978. in Catalogue Raisonné, nº. doc. 0944.78.

124 Hélio Oiticica uma Mangueira e Londres na Rota. Entrevista de HO a Norma Pereira Rêgo. Jornal Última Hora, Rio de Janeiro, 31 de janeiro de 1970. Catalogue Raisonné n. doc. 0869.70.

125 idem.

126 Oiticica, Hélio. A dança na minha experiência. Rio de Janeiro, 12 de novembro de 1965 a 1 o de abril de 1966. in Catalogue Raisonné n. doc. 0120.65, p. 72-73.

127 idem. 
emboscada da polícia. Foi amigo também de Miro, "um grande sambista" que lhe iniciou no samba. A Mangueira transformou-se em sua obsessão. Amigos próximos a Hélio, como Lfer ${ }^{128}$ (Luis Fernando Guimarães), afirmam que seu envolvimento com a Mangueira foi tão intenso que de fato Hélio tornou-se um exímio dançarino ${ }^{129}$. Desfilou pela Mangueira como passista pela primeira vez em 1965, ano do $4^{\circ}$ Centenário da cidade do Rio de Janeiro, e continuou desfilando até 1968: "quando a bateria de Mangueira começava a tocar era como se fosse dada a ordem para começar a viver"130. Aprendeu a sambar tão bem que se transformou num dos principais passistas da escola, além de apresentar-se em shows de samba com o Trio do Embalo Maluco, formado por ele, Nildo e um sujeito chamado Santa Teresa131. É deste período que Hélio formula uma teoria que viria desencadear no que considerou como "anti-arte", o Parangolé, que inicialmente designava apenas uma série de obras, capas, estandartes e tendas, mas que passou a representar toda a sua proposição ambiental ${ }^{132}$ : "um estado não intelectual da criação [que] tende a um sentido de participação coletiva e especificamente brasileiro"133 que lhe acompanha até o final de sua trajetória. Interessante é observar que a palavra Parangolé também surgiu nas ruas, produto do acaso:

Porque eu trabalhava no Museu Nacional da Quinta, com meu pai, fazendo bibliografia. Um dia eu estava indo de ônibus e na Praça da Bandeira havia um mendigo que fez assim uma espécie de construção. No dia seguinte já havia desaparecido. Eram quatro postes,

128 Hélio Oiticica explica que seu amigo Luis Fernando Guimarães nada tem a ver com o ator homônimo do ASDRUBAL. Lfer, como ele mesmo o apelidou, fez parte do Teatro OFICINA. Em Nova Iorque, Hélio fez uma série de fotos-acontecimento de Lfer com a CAPA 23 P30 Parangolé no cais 42, que se transformaram em posters numa série de 100 produzidos por Rubens Gerchman. Hélio ainda explica que batizou o amigo de Lfer porque o nome soa árabe "e como tenho algo de mouro no sangue nada mais me convém do que as coisas árabes", comenta em carta a Daniél Más. Rio de Janeiro, 8 de dezembro de 1978. Catalogue Raisonné n. doc. 0092.78.

129 Luis Fernando Guimarães, o Lfer, em conversa com a autora em fevereiro de 2012.

130 Hélio Oiticica uma Mangueira e Londres na Rota. Entrevista de HO a Norma Pereira Rêgo. Jornal Última Hora, Rio de Janeiro, 31 de janeiro de 1970. Catalogue Raisonné n. doc. 0869.70.

131 Oiticica, Hélio. Um mito vadio. Entrevista concedida a Jary Cardoso, em que estiveram presentes também Luís Fernando Guimarães, que tinha sido do grupo Oficina e o músico e compositor Jards Macalé. In Folhetim. São Paulo, domingo, 5 de novembro de 1978. Catalogue Raisonné, nº doc. 0944.78-p1-2.

132 HO. Entrevista a Marisa Alves de Lima. Revista Cigarra. Rio de Janeiro, 20 de julho de 1966. Catalogue Raisonné, n. doc. 0246.66.

133 idem. 
estacas de madeira de uns 2 metros de altura, que ele fez como se fossem vértices de retângulo no chão. Era um terreno baldio, com um matinho e tinha essa clareira que o cara estacou e botou as paredes feitas de fio de barbante de cima a baixo. Bem feitíssimo. E havia um pedaço de aniagem pregado num desses barbantes, que dizia: "aqui é..." e a única coisa que eu entendi, que estava escrito era a palavra Parangolé. Aí eu disse: "Essa a palavra"134

O Parangolé reflete a criação improvisada e coletiva tal como existe na Escola de Samba, em que cada um cria seu samba com improviso, segundo seu modo e sem seguir modelos: "os que o fazem seguindo modelos não sabem o que seja o samba ou sambar". Era desta forma que Hélio manifestava sua posição diante da realidade de um mundo dominado por imagens e informações, um mundo em que "o homem culto deixa de ser um criador de modelos para ser apenas um manipulador"135. Com o Parangolé era possível criar, Hélio contava com satisfação as possibilidades de subverter a ordem a partir do Parangolé, começando subvertendo a própria ideia de moda, construindo sua vestimenta a partir de uma invenção livre, espontânea, desprendida de noções de mau ou bom gosto, seguindo suas próprias aspirações e desejos. Assim fizeram Rosemary, Rosenely Souza Mattos, Helena e Lucia Cardoso, que Hélio fez questão de citar em entrevista de 1967, para que ficasse registrado as primeiras 'moças' a criarem algo para um Parangolé Coletivo ${ }^{136}$. O Parangolé segundo Hélio, diferentemente do happening, mais "sofisticado", voltado para uma elite ou 'contra' essa elite, segundo suas próprias palavras ${ }^{137}$, é uma experiência coletiva, sem preparação prévia, que deve se dar como uma sucessão de acontecimentos. A posição do Parangolé é anárquica, ético-social de sentido crítico, que Hélio formula em detrimento dos valores morais, éticos e religiosos, veículos da opressão social: "O Parangolé é grito de guerra: é a anti-cultura e ao mesmo tempo uma nova cultura é a demolição de qualquer tentativa de fixação arbitrária e rígida de

\footnotetext{
134 idem.

135 Hélio Oiticica faz referência à frase de Mário Pedrosa. in Barata, Mário (entrevista). Hélio Oiticica: a vanguarda deve jogar fora o esteticismo. Jornal do Commercio. Rio de Janeiro, 16 de julho de 1967. Catalogue Raisonné, n. doc. 0721.67.

136 idem.

137 idem.
} 
valores. O Parangolé é anti-militarista por exemplo, anti-moralista, antiesteticista"138.

Hélio apresentou seus Parangolés ao público pela primeira vez na ocasião da abertura da Exposição Opinião, de 1965, no Museu de Arte Moderna do Rio de Janeiro (MAM-RJ). Sua mais nova 'invenção', aspirava a transformação do mero espectador em participador, não poderia ter sido melhor 'inaugurada' no evento que representou a primeira manifestação efetiva das artes em reação ao golpe militar de 1964. O fato mesmo de tratar-se de um espaço institucionalizado, como o museu, apenas tencionou ainda mais a situação. Hélio chegou ao MAM com parte da bateria da Estação Primeira de Mangueira e vários passistas da escola de samba, tocando, dançando e vestindo os Parangolés, chocando o público desavisado e, principalmente, a administração do MAM que tratou de impedi-los de adentrarem o Museu. No dia seguinte o Parangolé de Oiticica era notícia e estampava diversos jornais, o tom era o de estranhamento: "Um grupo de passistas da Mangueira levou ao MAM a música proveniente da obra de Hélio Oiticica - Parangolé - formada por panos, plásticos, esteiras, telas, cordas, que ninguém sabia explicar, mas que o artista chamava de arte ambiental por excelência”139.

138 Oiticica, Hélio. Manuscrito de HO sobre manifestação ambiental e Parangolé. Rio de Janeiro, 14 de junho de 1966. Catalogue Raisonné, n. doc. 0247.66.

139 "Museu de Arte Moderna abre 4 exposições exibindo obras de 33 artistas”. Jornal do Brasil, 13 de agosto de 1965. In Catalogue Raisonné, n. doc. 0620.65. 


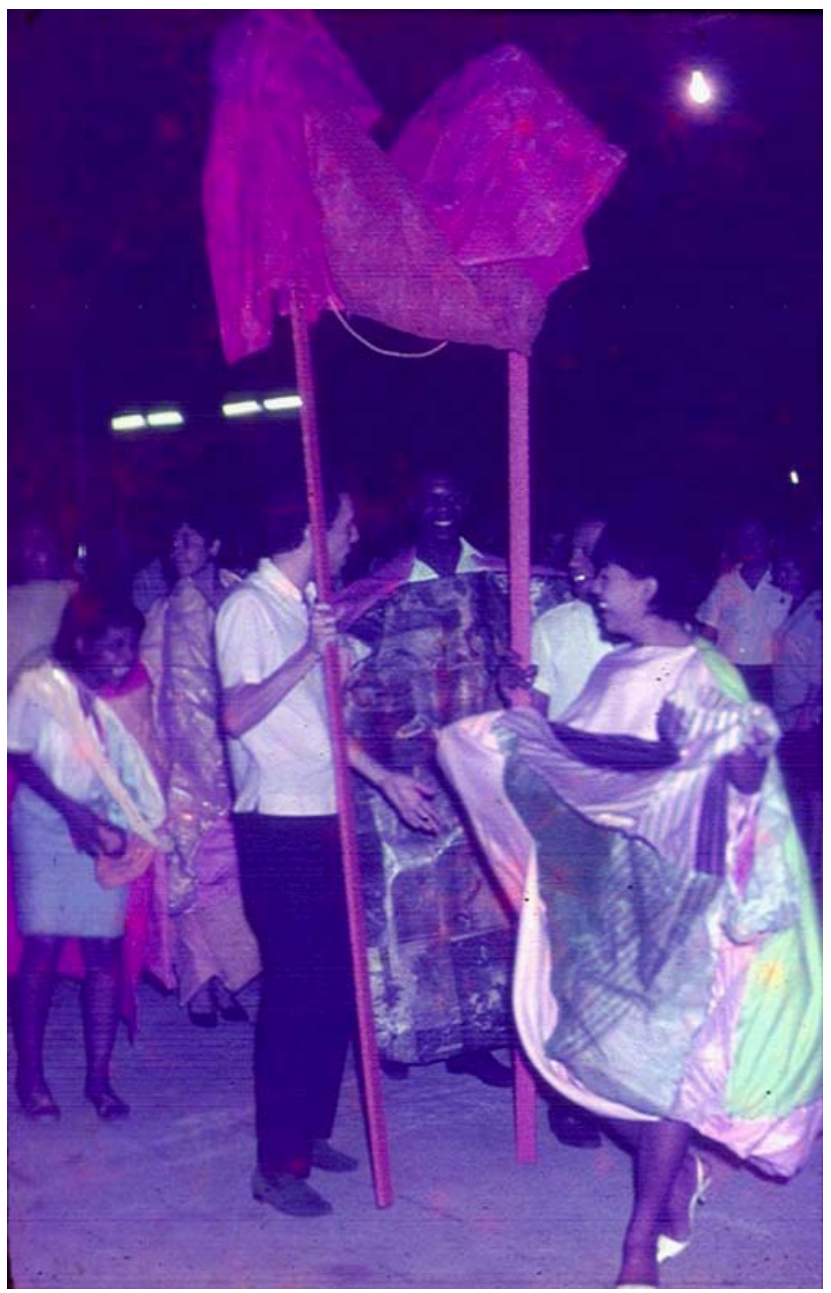

Figura 8 O Parangolé no MAM, 1965. Catalogue Raisonné n. doc. 2016.65

Essa posição ética sobrepõe-se a uma preocupação estética e está presente de forma bastante exemplar no Bólide-Caixa 18 B33, de 1966, denominado Homenagem a Cara de Cavalo, que retrata o bandido morto pela polícia em 1964. Apesar de Cara de Cavalo ter sido seu amigo, Hélio não quis realizar uma 'homenagem romântica', como ele mesmo afirmou, mas 'objetivar' um problema social. Segundo Hélio, Cara de Cavalo foi eleito bode expiatório, "sua morte foi fruto de uma sociedade preconceituosa, de uma legislação caduca, minada em todos os sentidos pela máquina capitalista consumitiva" (sic). Com Homenagem a Cara de Cavalo, Hélio procurou mais do que "lamentar um crime”, realizar "uma atitude anárquica contra todos os tipos de forças armadas: polícia, exército etc.” 140. O Bólide Homenagem a Cara de Cavalo (figura 9) é composto por uma caixa (caixão), sem tampa e com uma das laterais estendidas ao chão com fotografias do bandido morto, braços abertos como um

140 Oiticica, Hélio. Texto de HO sobre Éden. (local não atribuído), 25 de fevereiro de 1969. Catalogue Raisonné n. doc. 0365.69.-p3. 
crucificado (imagem que foi veiculada pela imprensa brasileira na época). No fundo da caixa, sobre grades de ferro, um saco de plástico transparente que contém pigmentos, com uma almofada, que traz os seguintes dizeres: “Aqui está, e ficará! Contemplai seu silêncio heroico".

Essas proposições continham lições que Hélio aprendera sobre ética e liberdade ensinadas pelo pai e pelo avô. Seu pai, José Oiticica Filho (1906-1964), engenheiro, professor de matemática, entomólogo e um dos mais importantes fotógrafos do seu tempo, costumava dar o seguinte conselho ao filho: “Tudo pode ser feito, não se prenda ao 'não pode’”141. Seu avô, José Oiticica (1882-1957), um importante líder anarquista, filólogo, professor, escritor, editor do jornal “Ação Direta”, e autor de “O Anarquismo ao alcance de todos”, costumava falar o quanto padres e militares eram seres desprezíveis: “militar é treinado pra matar”, enquanto que padre é “treinado pra matar o espírito da pessoa"142. Hélio ouvia com atenção as histórias que seu avô lhe contava, como a de quando foi chamado para participar de um júri policial. Como recusar participar do júri poderia custar sua prisão, José Oiticica foi logo dizendo: “olha eu vou fazer parte do júri, mas eu aviso de antemão que eu absolverei sempre”143. A ideia de condenar ou delatar alguém, mesmo sob tortura (José Oiticica foi preso várias vezes e chegou a ser torturado), foi passada para Hélio como um crime ainda maior, pior do que matar, como ele mesmo conta em entrevista em $1978^{144}$.

\footnotetext{
141 Waly Salomão. Qual é o Parangolé e outros escritos. Rio de Janeiro: Rocco, 2003. p. 22.

142 Hélio mesmo conta essa passagem de sua vida em entrevista de 1978. HO. "Um Mito Vadio", entrevista publicada em 5 de novembro de 1978, Folhetim. Catalogue Raisonné, n. doc. 0944.78

143 HO. “Um Mito Vadio", entrevista publicada em 5 de novembro de 1978, Folhetim. Catalogue Raisonné, n. doc. 0944.78

144 Oiticica, Hélio. "Um Mito Vadio”, entrevista publicada em 5 de novembro de 1978, Folhetim. Catalogue Raisonné, n. doc. 0944.78
} 


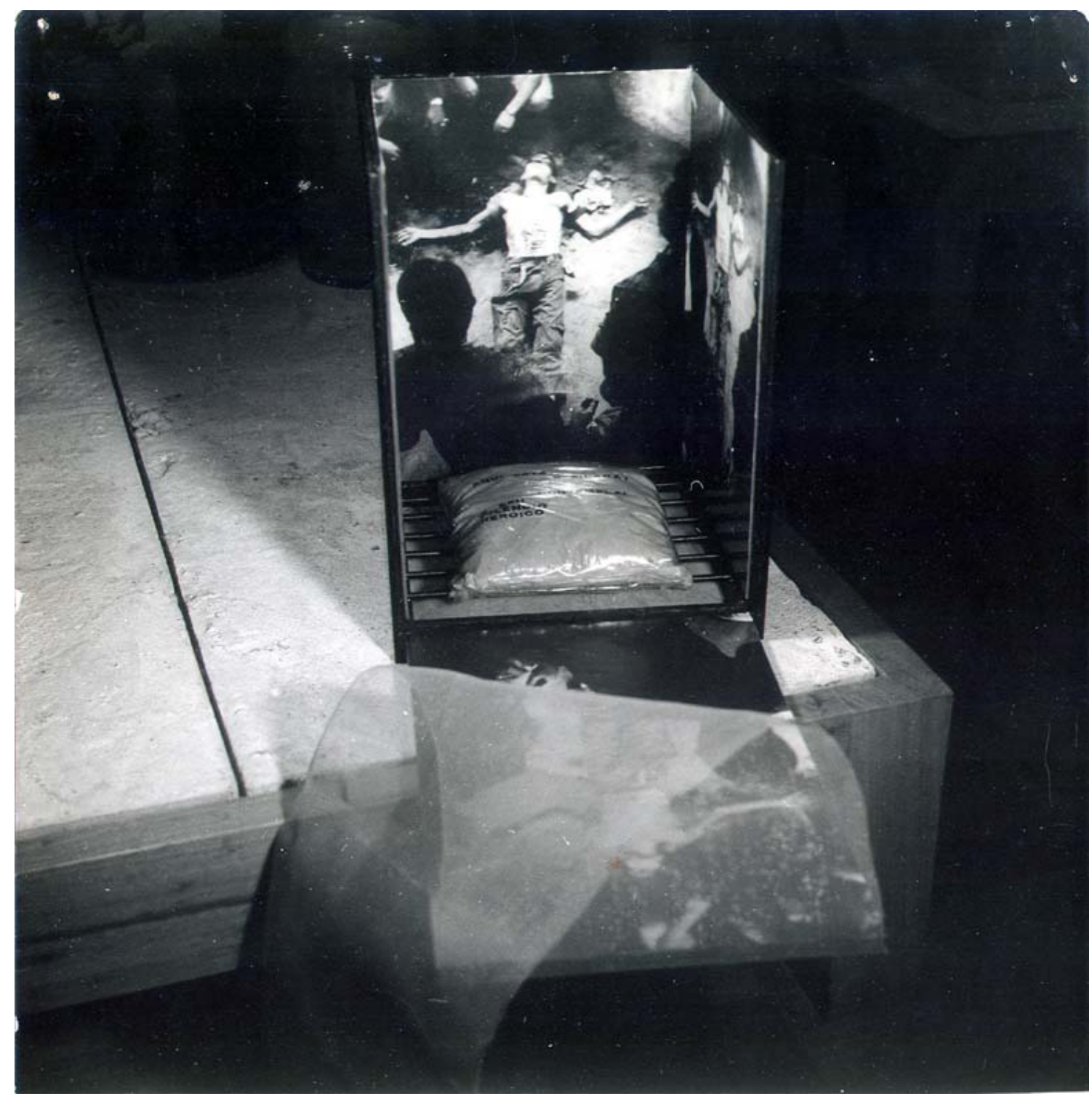

Figura 9 Bólide Caixa 18 Homenagem a Cara de Cavalo, 1966. in Catalogue Raisonné n. doc.

Enfatizando, posteriormente, mais uma vez o problema da 'opressão social sobre aquele que é marginal', Hélio construiu a bandeira SEJA MARGINAL SEJA HERÓI, que trazia a frase em letras garrafais. A bandeira foi utilizada no show de Caetano Veloso na boate Sucata no Rio de Janeiro, em 1968. Nesta ocasião, a bandeira foi apreendida e o show interditado pela Polícia Federal. Neste mesmo ano, em maio, enquanto Paris se via em meio a barricadas e protestos estudantis, Rogério Duarte criou junto com Hélio a Apocalipopótese, "uma mistura de apocalipse e apoteose, ou hipótese apoteótica do apocalipse?" Tanto Hélio quanto Rogério Duarte preferiram não determinar seu significado: "a utilidade é a negação da liberdade e a liberdade é a 
utilidade da negação"145. O Apocalipopótese, segundo Hélio, marcou a etapa definitiva, nova, nas experiências "vanguardescas" brasileiras146. Apocalipopótese aconteceu em agosto de 1968, em frente ao Pavilhão Japonês que fica no Aterro do Flamengo, com a participação de diversos artistas e do público. A série de acontecimentos que marcou aquela tarde no Aterro do Flamengo teve como tônica comum o sentido experimental e a participação ${ }^{147}$, o que contribuiu para instaurar um clima de tensão, prazer e violência, uma vez que poderiam sofrer represália policial a qualquer momento da polícia148. Dotado também de uma "posição ética", Apocalipopótese fazia confluir experimentalismo, anarquismo e marginalidade, numa criação coletiva. Esta "posição crítica" articulada à experimentação foi o modo pelo qual esses artistas acabaram se manifestando politicamente, buscando romper a partir de suas atividades transgressoras, com as propostas de resistência em desenvolvimento no país. O caráter dessas ações (múltiplas, descontínuas e surpreendentes) aproximamse das ações guerrilheiras, tendo Celso Favaretto apontado a similaridade dessa atitude com aquela que tomou conta das ruas de Paris em maio de 1968149 .

145 Oiticica, Hélio. op., cit., Morais, Frederico. Apocalipopótese no aterro: arte de vanguarda levado ao povo. Jornal Diário de Notícias. Rio de Janeiro, 26 de julho de 1968. Catalogue Raisonné n. doc. 2084.68.

146 Hélio, Oiticica. Apocalipopótese. Brighton, 9 de outubro de 1969. in Catalogue Raisonné n. doc. 0381.69 .

147 Algumas das manifestações: os Ovos de Lygia Pape, as Urnas Quentes de Antonio Manuel, que abertas a machadadas, liberavam panfletos e imagens da ditadura, as Capas de Hélio Oiticica, vestidas por passistas, os cães amestrados, conduzidos por Rogério Duarte.

148 Os filmes que registraram o Apocalipopótese foram apreendidos pela polícia.

149 Favaretto, Celso. A invenção de Hélio Oiticica. São Paulo: EDUSP/FAPESP, 2000. 2ª ed. p. 181. 


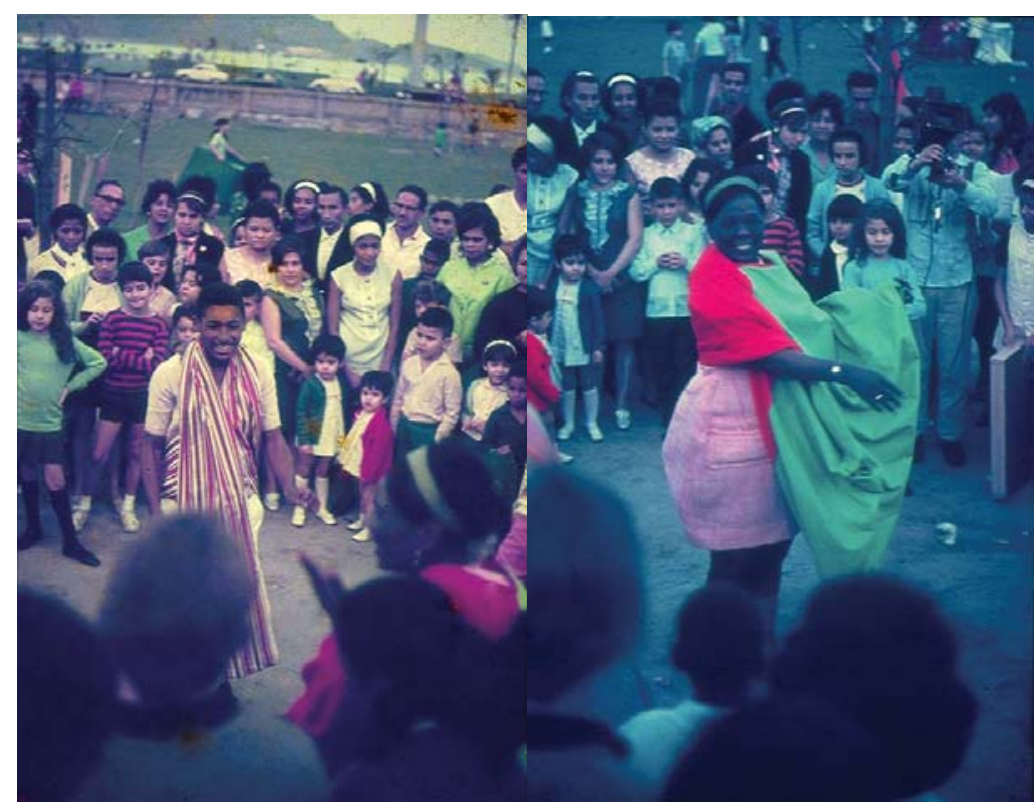

Figura 10 Imagens do evento Apocalipopótese. in Catalogue Raisonné, n. doc. 2139.68.

É contra toda a "parafernália-cultural-patriótico-folclórica-nacional opressiva" que Hélio se posiciona. A formulação do Parangolé funda o que Hélio denominou como sendo raiz Brasil, raiz aberta que se bifurca numa imagem-estrutura a partir da Tropicália, e num comportamento-estrutura, a partir do Barracão ${ }^{150}$, ambos remetendo à imagem do labirinto. Tropicália é um Penetrável, proposição que surgiu na trajetória de Hélio a partir da própria evolução de seu trabalho no início dos anos 1960, quando ainda integrava o movimento Neoconcreto. Neste período, Hélio desenvolveu uma sequência lógica que teve como eixo o "desenvolvimento nuclear da cor”, no qual desprendeu os planos de cor da tela e estruturou-os no espaço. Ao colocar a cor no espaço real, Hélio integrou o 'espaço cor' à própria "experiência espontânea das pessoas", rompendo com a contemplação ${ }^{151}$. Daí nasceram os penetráveis, estruturas labirínticas onde o espectador adentra, percorrendo os caminhos segundo um ritmo cromático previsto, que possui uma 'gênese formal' e 'vivencial'152.

O Penetrável Cães de Caça, formulado em 1961, exemplifica esta posição na qual a reintegração do indivíduo ao espaço das 'vivências cotidianas' dá-se numa

\footnotetext{
150 Oiticica. Hélio. Barracão. (Texto de HO sobre "formulação da ideia de Parangolé"). Londres, 19 de agosto de 1969. Catalogue Raisonné, n. doc. 0452.69

151 Gullar, Ferreira. Os "Penetráveis" de Oiticica. Jornal do Brasil, Rio de Janeiro, 7 de dezembro de 1961. in Catalogue Raisonné n. doc. 0578.61.

152 Oiticica, Hélio. Texto sobre Arte. (Diário de HO contendo textos sobre arte, sobre núcleos, sobre projeto cães de caça, entre outros). Rio de Janeiro, 1 de dezembro de 1959 a 11 de maio de 1964. in Catalogue Raisonné n. doc. 0182.59.
} 
ordem espaço temporal-estética, a partir da estrutura do labirinto. Posteriormente, Tropicália surge a partir da vontade de Hélio em instituir um estado da arte brasileira de vanguarda, de 'lançar' uma imagem obviamente brasileira153. Tropicália é composto por dois Penetráveis, PN2 (1966) A Pureza é um Mito e PN3 (1966-1967) Imagético. Ao adentrar Tropicália o sujeito depara-se com plantas, areias, araras, poemas-objeto, capas de Parangolé, aparelho de TV. Nesta mistura de elementos tropicais e tecnológico, mergulha-se numa série de sensações tácteis, visuais, sonoras, olfativas que, segundo Hélio, lembram as próprias sensações que tinha ao caminhar "pelas quebradas" do morro.

O penetrável Cães de Caça (1961) vem confirmar que a imagem do labirinto como estrutura apropriada para integração 'indivíduo e espaço' é anterior mesmo a sua descoberta do morro da Mangueira. Entretanto, Hélio reconhece na organicidade da favela a estrutura ideal para o 'descondicionamento social' do indivíduo. A formulação do Barracão, em 1968, condensa essas ideias a partir de uma 'estruturacomportamento', que Hélio define como uma comunidade do lazer, um lugar que funcionaria como um 'ninho', no qual as pessoas estabelecendo uma relação afetiva com o lugar poderiam criar de maneira mais primária e imediata154. Posteriormente, Hélio explica que a ideia de multiplicação, reprodução e crescimento contida nos Ninhos confluiu na ideia de comunidade, na proposição do Barracão: enquanto "tropicália foi a descoberta do precário num confronto com a arte experimental internacional; barracão é a ampliação da ideia de crelazer em contextos mais gerais"155.

O Barracão como referência do que Hélio chamou de 'comportamentoestrutura' marca o processo da dissolução do 'objeto' como expressão estética, abrindose a "experiências mais comprometidas com o comportamento individual de cada participador"156. A 'abertura' dessas estruturas relaciona-se às proposições voltadas ao comportamento, portanto, envolvem os problemas "sensoriais", de sensação e

153 Oiticica, Hélio. Texto de HO sobre sua obra. (Texto sobre Tropicália e Nova Objetividade). Rio de Janeiro, 4 de março de 1968. in Catalogue Raisonné n. doc. 0128.68.

154 Oiticica, Hélio. op., cit. Campos, Gilse. Hélio Oiticica, uma arte sem medo. Jornal do Brasil. Rio de Janeiro, 29 de janeiro de 1970. Catalogue Raisonné n. doc. 0867.70.

155 Oiticica, Hélio. Jornal O Globo, 17 de setembro de 1970, pág. 11. Catalogue Raisonné, n. doc. 1887.70.

156 Oiticica, Hélio. O Aparecimento do Suprasensorial. Rio de Janeiro, dezembro de 1967. in Catalogue Raisonné n. doc. 0108.67. 
estímulo, onde o próprio participador elabora "dentro de si mesmo suas próprias sensações, as quais foram "despertadas" por tais sensações", dando o sentido que Hélio chamou de suprasensorial157. Entretanto, enquanto Hélio desenvolve o Aparecimento do Suprasensorial na Arte, em 1967, a 'abertura' das estruturas relacionadas à ideia do "recinto-obra", "lugar-recinto-contexto-obra", na qual se encontra a proposição do Barracão, articula-se às experiências que estabelece em Londres, a partir de dezembro de 1968, principalmente, por meio do contato com o grupo Exploding Galaxy e da própria experiência de sua exposição na Whitechapel Gallery 158 .

Em Londres, Hélio sentiu que sua posição marginalizada, sua proximidade com a favela da Mangueira, sua produção transgressora e experimental que desenvolvia no Brasil, transformou-se de "pecado" em "virtude": "tudo o que de folclore me retratavam foi posto abaixo, porque em lugar de maconheiro e decadente descobriram uma pessoa inteligente e criadora"159, declara em carta ao amigo Amílcar de Castro.

Morando em Londres, Hélio então conheceria o 'subterrâneo' pela via do cinema e da música, elementos que posteriormente são incorporados em suas experiências artísticas desenvolvidas em Nova Iorque, sua estada seguinte. Porém, além do 'contato vivência' com o grupo Exploding Galaxy e da própria experiência na Whitechapel Gallery, que também denominou como uma "experiência galáxica", destacam-se sua proximidade com o rock e sua experiência nos históricos shows na Ilha Wight no sul da Inglaterra, Pink Floyd no Central Park, numa visita rápida a Nova Iorque, e o filme "underground" Chelsea Girls, de Andy Warhol, o qual lhe fez "sentir vontade de fazer cinema", comenta: "é incrível pois ele cria uma linguagem-cinema nova, a meu ver; e mostra que o filme "underground" é o que é mesmo importante nessa década, possibilitando tudo" 160 .

A cidade de Nova Iorque representou para Hélio o ambiente ideal para colocar em prática tudo o que havia 'despertado' em Londres: "gosto do clima radicalizado de amoralidade total de Nova Iorque ", "a calma de Londres me irrita, às vezes sinto que estou morrendo", comenta em carta a Lygia Pape. Em Nova Iorque "não há a busca de

\footnotetext{
157 idem.

158 Estas questões tornam-se mais evidentes no texto "A obra, seu caráter objetal, o comportamento", que pelo conteúdo deve ter sido escrito em Londres. in Catalogue Raisonné n. doc. 0160.68.

159 Oiticica, Hélio. Carta a Amilcar de Castro. Londres, 18 de setembro de 1969. in Catalogue Raisonné n. doc. 0930.69.

160 idem.
} 
nada, de nenhuma nova moral ou filosofia ou nada; é a completa destruição de qualquer princípio moral"161. De fato, Nova Iorque tornou-se para Hélio "o supraurbano mundial", "insubstituível", a "babylon". Lá encontrou uma comunidade de artistas que misturavam cinema, performance e música integrando as obras experimentais à vida cotidiana. Gordon Matta-Clark, John Cage, Yoko Ono, Robert Smithson e Jack Smith são alguns dos nomes que compartilhavam de experiências similares, vivendo em Nova Iorque no mesmo período que ele. Em Nova Iorque, Hélio coloca em prática a ideia de obra como um 'comportamento-vida'. A fusão de cinema, performance e música torna-se o elemento chave para suas experiências. No âmbito geral daquela comunidade de artistas, uma constante: seus lofts, moradia, lugar da intimidade, abrem-se como espaços coletivos, trocas de experiências e vivências, performances, filmes, instalações, enquanto a rua torna-se extensão de suas proposições, lugar para o vivido, apropriado para as intervenções estéticas e políticas $^{162}$.

No Rio de Janeiro, de volta ao Brasil em 1978, Hélio incorpora a deambulação como parte de suas proposições, como vivências descondicionantes que possuem como prerrogativa desalienar o indivíduo. Seu “deambular crítico-criativo”163, está diretamente relacionado às transformações urbanas sofridas na cidade do Rio de Janeiro, principalmente, a partir dos anos 1960, e que se fizeram sentir consideravelmente no fim dos anos 1970. A perda de escala urbana, a partir do abrupto crescimento dos subúrbios e a verticalização nos bairros nobres, bem como os processos de 'espetacularização' urbana, a partir de empresas imobiliárias que visavam apenas "desembaraçar" os morros para que ficassem 'livres' para a construção de habitações de luxo, foram alguns dos processos urbanos que ocasionaram uma drástica mudança na 'forma' da cidade ${ }^{164}$. As deambulações de Hélio neste período representam uma resposta a essas transformações, uma tentativa de apropriar-se desta

161 Oiticica, Hélio. Carta a Lygia Pape. Nova Iorque, 4 de agosto de 1969. Catalogue Raisonné n. doc. 1049.69.

162 As relações que estes artistas mantiveram entre eles vêm sendo delineadas pouco a pouco, como num quebra-cabeças. Em 2005, foi organizado na Galeria Lelong, em Nova Iorque, uma mostra intitulada Organized Delirium: New York 1970-1978, numa leitura que aproxima as experiências de Hélio Oiticica, Neville D'Almeida, Matta-Clark, Yoko Ono, Jack Smith e Robert Smithson, no período em que viveram naquela cidade.

163 Morais. F. Pequeno roteiro cronológico das invenções de Hélio Oiticica. In: Catalogue Raisonné $\mathrm{n}^{\circ}$ doc. 2471.sd.

164 Abreu, Mauricio de A. Evolução Urbana do Rio de Janeiro: IPLANRIO (Instituto de Planejamento Municipal, Jorge Zahar Editor, 1988. $2^{\text {a }}$ ed. 
'nova' cidade, procurando 'poetizar esses espaços' a partir da apreensão 'psicogeográfica' dos lugares abandonados da cidade. 



\subsection{A Deambulação de HO em Londres}

Os anos 1960 foram marcados internacionalmente como um período de governos ditatoriais, pela Guerra Fria, pela construção do Muro de Berlim, por avanços tecnológicos e científicos que contribuíram para conquistas espaciais que culminaram em 1969, com a chegada do homem pela primeira vez à Lua, mas também para o incremento de artefatos de guerra que gerou uma tensão generalizada em torno da iminência de um conflito nuclear. Mesmo nos países que não viviam ditaduras políticas, a atmosfera era de repressão. Enquanto a tensão política em torno de disputas econômicas entre as grandes potências se acirrava, crescia uma sociedade em torno de uma cultura capitalista que fincava seus valores em torno do consumismo. Em contrapartida, desde os anos 1950, despontavam movimentos que incitavam a uma postura oposicionista, movimentos que tomariam força na década seguinte. Os grupos que estão na origem da Internacional Situacionista ilustram este cenário contracultural, bem como a própria IS que emergiu da crítica à sociedade capitalista e à cultura de consumo em 1957. Posteriormente, outros movimentos despontaram, confirmando a ascensão de uma cultura underground, psicodélica e contestatória que também irá marcar os anos 1960. Esses movimentos viam a luta pela independência da Argélia (1954 e 1962), a Guerra do Vietnã (1955 e 1975), entre outros conflitos, como acontecimentos desagregadores, fruto de uma sociedade capitalista e autoritária. Este caráter contracultural é herdeiro das manifestações pacificadoras anteriores, que marcaram o período pós $2^{\mathrm{a}}$ Guerra Mundial, desenvolvidas por uma juventude que ficou conhecida como Geração Beat. Os beatniks subscreveram, ainda no final dos anos 1940 e 1950, um estilo de vida anti materialista, desenvolvendo experiências e ideias impregnadas por uma revolta pessoal e espiritual, embora desprovidas de caráter ideológico ${ }^{165}$. Nos EUA a cultura jovem inspirada na Geração Beat, ficou conhecida como hippies, que pregavam "Paz e Amor". Entretanto, o espírito "paz e amor" foi sendo transformado no decorrer dos anos 60, e a juventude passou de uma certa 'ingenuidade' para uma politização que eclodiu, já nos finais da década, em

165 Rycroft, Simon. Swinging City. A Cultura Geography of London 1950-1974. Ashgate, 2011. 
manifestações nas quais os jovens tomaram as ruas em protestos, como foi o caso do emblemático Maio de 1968, que apesar de ter ocorrido na cidade de Paris, refletiu no mundo todo. Estudantes e operários gravaram nos muros de Paris as frases que se tornariam slogan do próprio movimento, como por exemplo: "La poésie est dans la rue" (A poesia está nas ruas), "À bas la société de consommation" (Abaixo a sociedade de consumo), "À bas la société spectaculaire-marchande" (Abaixo a sociedade espetacular mercantil), "Abolition de la société des classes " (Abolição da sociedade de classes), "Abolition de l'aliénation" (Abolição da alienação), entre outras, que agregavam um tom mais politizado aos refrões já conhecidos daquela juventude, como "Flower power", "Make love not war".

Em Londres a ascensão de uma cultura psicodélica também marcava uma oposição aos valores da sociedade capitalista e ao estado geral de repressão. Apesar de não viverem sob um regime ditatorial, os movimentos contraculturais eram perseguidos e recriminados. Em 29 de abril de 1967, no salão do complexo Alexander Palace, aconteceu o primeiro grande evento psicodélico, denominado 14 Hour Technicolour Dream. Este evento surgiu como forma de angariar fundos para custear processos jurídicos enfrentados pelo The International Times, o primeiro grande jornal Underground, criado em 1966, e perseguido pela polícia londrina e pela imprensa popular166.

O ambiente do 14 Hour Technicolour Dream foi composto por torres de luz, efeitos especiais, brinquedos de parque de diversão, num grande espaço, com palco e sem cadeiras, onde o público podia circular livremente (estimou-se um público em torno de 5.000 pessoas ${ }^{167}$ ). Diversos acontecimentos simultâneos criavam uma atmosfera caótica e imprevisível, intensificada pelos efeitos alucinógenos do LSD, droga usada massivamente. O evento reuniu poetas de vanguarda, dançarinos, bandas de rock como Pink Floyd, Soft Machine (grupo de música progressiva), The Files (que incluía figuras andrógenas), The Crazy World of Arthur Brown (Arthur desceu sobre o palco agarrado a uma corda balançando acima do público, com seu capacete em

166 Michael Chapman explica que "os recentes escândalos cercando o grande empresário dos meios de comunicação internacional, o australiano Rupert Murdoch, demonstrou a cooperação antiética entre a imprensa popular e a polícia, vistas na perseguição de pessoas e grupos incômodos (publicação de material sensacionalista nos jornais) e nas escutas telefônicas não autorizadas, que levou Murdoch a fechar o jornal The News of the World. Michael Chapman em entrevista concedida à autora em agosto de 2012.

167 idem. 
chamas), bem como, apresentações de esquetes teatrais e Happenings. Todos esses acontecimentos possuíam um efeito chocante para época, como relata Michael Chapman 168 :

Yoko Ono encenou uma atividade no meio do público junto com Anthony Cox seu marido. Intitulada - "A pretty girl is like a Manifesto", ou "Cut Piece". Um homem foi convidado a desnudar a modelo Carol Mann que se vestia de freira. Sua roupa foi recortada com a ajuda de uma tesoura, que por sua vez era conectada a um microfone que amplificou o som produzido para o público geral.

O americano Jim Haynes, co-fundador do jornal Internacional Times e coorganizador do 14 Hours Technicolour Dream, criou um grupo que também possuía uma proposta político cultural bastante alternativa, o Arts Lab ${ }^{169}$. O caráter alternativo começa pelo próprio espaço físico que abrigava um programa multifuncional, com salas de uso flexíveis (teatro, oficinas, galeria, cinema, restaurante vegetariano), e com atividades experimentais que podiam durar um dia inteiro. A sala de projeções refletia a proposta experimental e vivencial do grupo, forrada com espuma, onde o público podia assistir a filmes sentado ou deitado no chão ${ }^{170}$.

Neste cenário londrino destacava-se também a Signals Gallery, referência internacional por possuir um programa inovador de exposições e pela edição do informativo Signals, que servia para discutir novas propostas nas artes e na literatura.

A galeria Signals foi o principal palco de exposição para a vanguarda internacional. Artistas como Takis, Camargo, Soto, Kenneth

168 O inglês Michael Chapman, poeta performático, artista, antes de integrar o grupo Exploding Galaxy, participou junto à banda Soft Machine, com eles viajou em 1967, para praia St. -Aygulf, em Côte D'Azur para trabalhar na discoteca anexa ao evento que ficou conhecido como "la première mondiale d'une ambience tout à fait Psychédélique" (a estreia mundial de um ambiente totalmente psicodélico). Fez parte do grupo de cineastas Zanzibar e participou do filme "Acéphale". Conviveu no final dos anos 1960, com os brasileiros Hélio Oiticica, Lygia Clark, Gerald Thomas e Caetano Veloso, na época residentes em Londres. Hoje (desde os anos 1980) vive no Brasil, no Estado do Rio Grande e leciona na Fundação Universidade de Rio Grande.

169 O Arts Lab localizava-se em Drury Lane, na área central de Londres.

170 O centro servia também como base para o 'London Filomakers Coop', entre outros grupos como 'Guerrilla Poets', grupo de poetas que declamava poemas na rua interagindo com o público, organizado por Donald Gardner, do qual Michael Chapman participou, além de um grupo de vídeo experimental do americano Jack Moore (certa vez Jack Moore instalou uma câmera de vídeo numa sala e convidou pessoas que mal se conheciam a se fechar dentro e transar para o público que assistia no lado de fora). Michael Chapman em entrevista concedida à autora em julho de 2012. 
e Mary Martin, Li Yuan-Chia, Gerhard von Gravenitz e Lygia Clark tiveram a oportunidade de experimentar e fazer exposições em grande escala. [A galeria atraiu um público diverso] que incluía entre artistas e estudantes, também arquitetos, engenheiros, escritores, cientistas, tecnólogos, designers, industriais, médicos, enfermeiros e professores. [...] O perfil da Signals era cosmopolita, experimental e interdisciplinar ${ }^{171}$.

Entretanto, a Signals fechou em 1967, impulsionando o artista filipino David Medalla, que dirigia a galeria junto com Paul Keeler, a criar o grupo Exploding Galaxy. David Medalla "aparece como uma mistura incongruente de homem renascentista e nômade transnacional marginal", como definiu Guy Brett ${ }^{172}$, e pretendia com o Exploding Galaxy criar "uma estrutura social criativa, que pudesse interagir com o público sem a mediação das instituições, tomando como modelo o regimento estético de sua própria obra"173. Segundo Jill Drower, a visão de David Medalla ao fundar o grupo era a de criar uma "metáfora humana em sinergia com o processo de transformação visto nas nuvens de espuma geradas por suas máquinas "cloud canyons", "oozing out living shapes that formed and reformed" (escoando formas vivas que formavam e reformavam) ${ }^{174}$. Nas palavras do próprio David Medalla, a ideia a partir do Exploding Galaxy era "criar uma situação na qual a dança, poesia, canto, pintura e a escultura poderiam cooperar e penetrar uma na outra, como fizeram nas culturas históricas"175 David também acreditava que este era o caminho para se quebrar a invisível barreira entre criador e espectador ${ }^{176}$.

\footnotetext{
171 Brett, Guy. Exploding galaxies: the art of David Medalla. London: Kala Press, 1995. p. 49. (trecho traduzido por Michael Chapman em entrevista concedida a autora em julho de 2012).

172 Ibid., p. 14-15.

173 Michael Chapman em entrevista concedida a autora em julho de 2012.

174 Drower, Jill. The Exploding Galaxy. The Third Text: critical perspectives on contemporary art and culture. London, v. 22, n. 2, p. 229-236, 2008. op. cit. Chapman, Michael. Entrevista concedida a autora em julho de 2012.

175 ibid., p. 231. op. cit. Chapman, Michael. Entrevista concedida a autora em julho de 2012.

176 Apud Chapman, Michael. Entrevista concedida a autora em julho de 2012.
} 


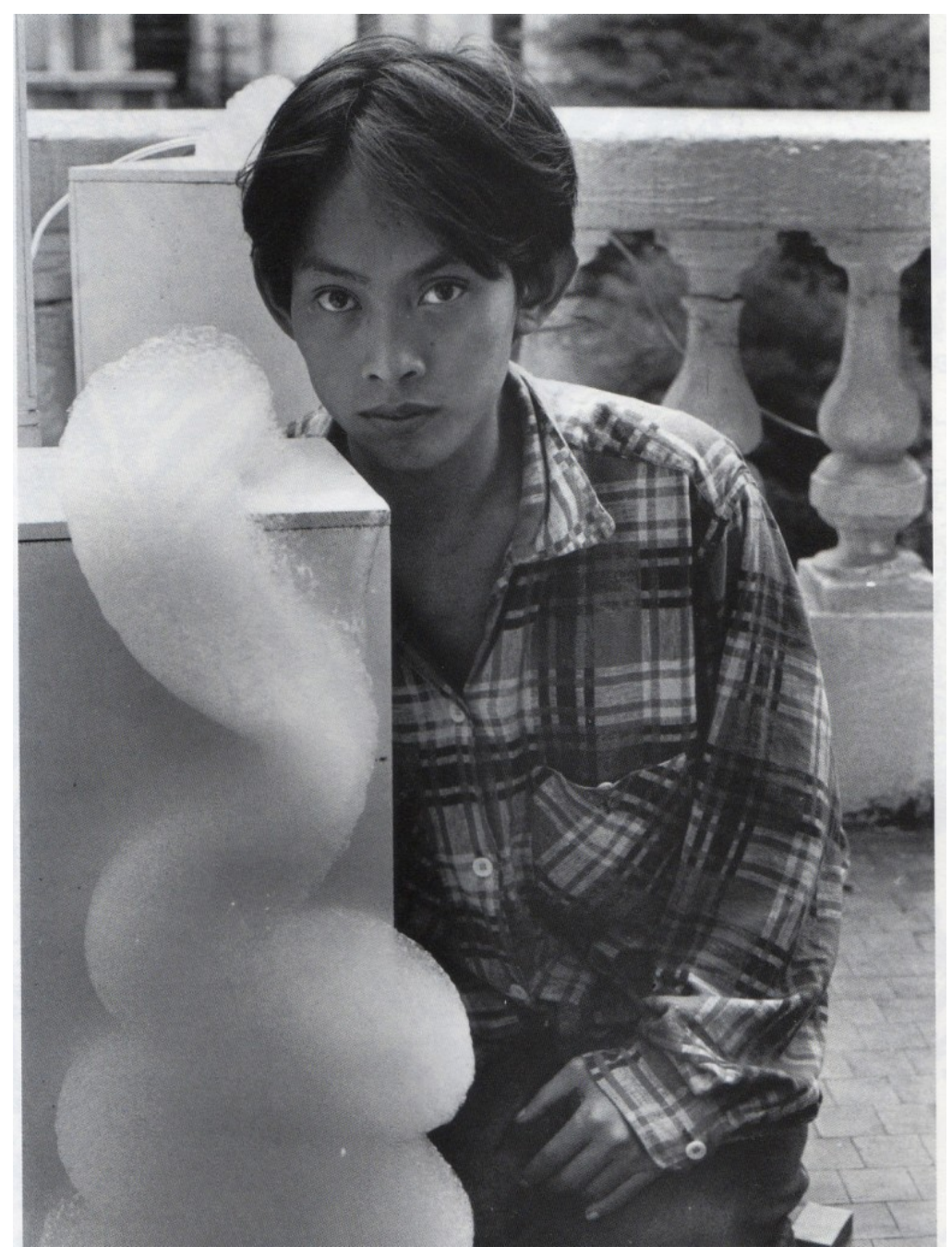

Figura 11 David Medalla, Cloud Canyons (Bubble Muchine), Londres, 1964.

http://www.1fmediaproject.net/2011/05/19/david-medalla-cloud-canyon-n-14-19632011-newmuseum-n-y/ (acessado em 19/09/2012)

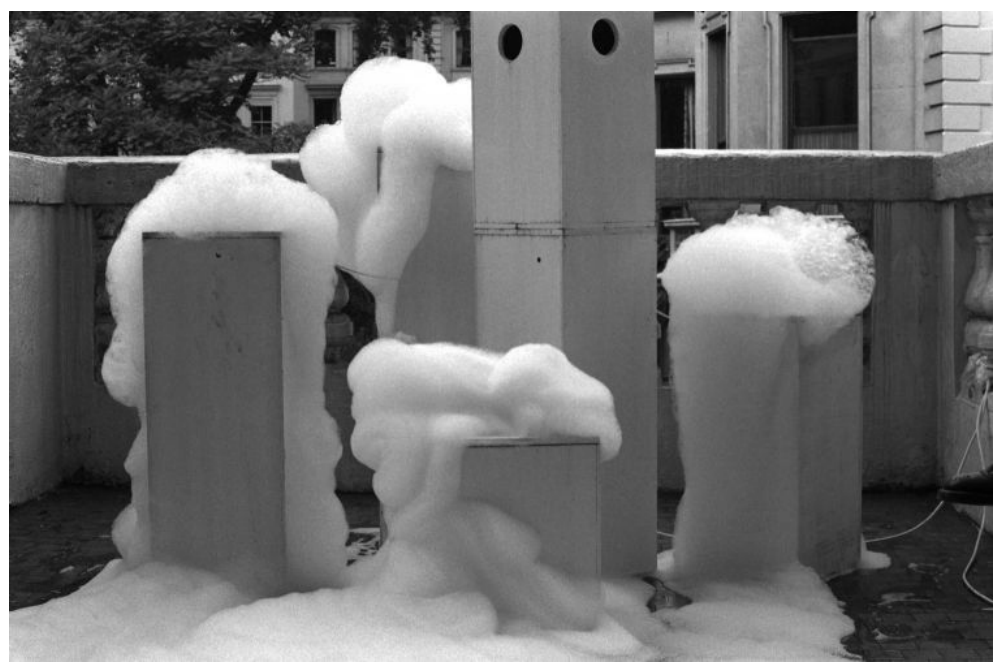

Figura 12 David Medalla, Cloud Canyons (Bubble Muchine), Londres, 1964.

http://entretenimento.uol.com.br/album/clay_perry_sp_album.htm (acessado em 19/09/ 2012) 


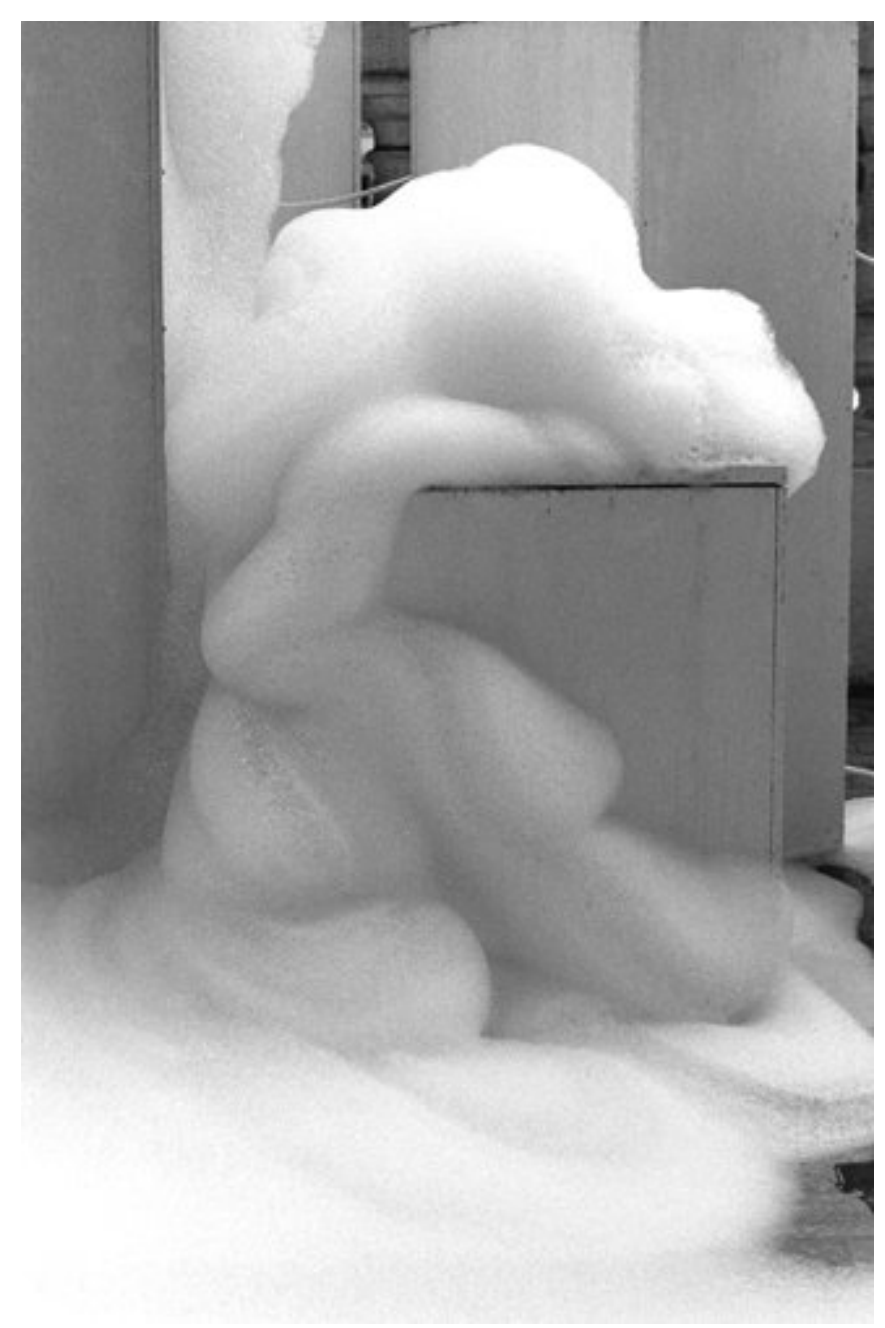

Figura 13 David Medalla, Cloud Canyons, Londres, 1964.

http://entretenimento.uol.com.br/album/clay_perry_sp_album.htm (acessado em 19/09/ 2012)

O Exploding Galaxy foi formado por uma população flutuante de umas quarenta pessoas de diversas nacionalidades e histórias de vida. Poetas, artistas plásticos, atores, cineastas, dançarinos e jovens sem experiência maior nas artes, dispostos a experimentar coletivamente a vida, examinar e avaliar todos os aspectos do cotidiano, de forma livre e espontânea. O núcleo do grupo vivia na mesma casa, cedida por Paul Keeler, localizada na Balls Pond Road177, n. 99, um prédio de três andares no bairro de Dalton no norte de Londres. Era o espaço de discussões, oficinas, onde o grupo vivia como uma comunidade sem regra alguma a seguir. Segundo Stefan

177 Michael Chapman explica que o endereço agregava um caráter enigmático, uma vez que a palavra "balls" possui em inglês um duplo sentido: "testículos" e "saco", utilizada de forma rude para opinar a respeito de algo considerado "errado, que não presta ou ridículo". (em entrevista à autora em julho de 2012). 
Szcelkun, o Exploding Galaxy "criaram uma cultura tribal (...), feita sem dinheiro, a partir dos detritos materiais da cidade"178:

Á entrada, o primeiro piso formava um porão geral, um espaço para discussões, oficinas. Na cozinha ao lado, sustentado contra a parede, havia um trabalho cinético parcialmente quebrado do artista plástico Jesus Rafael Soto. (...) Cada um de nós simplesmente criou ou apropriou seu próprio espaço. Lembro que certa vez as tábuas do chão me serviam de cama ${ }^{179}$.

O principal modus operandi desenvolvido pelo grupo advinha do próprio comportamento de viver e explorar a arte como vida. Eles deambulavam pelas ruas londrinas, de forma espontânea, com um ou mais integrantes, examinando a cidade, os comportamentos das pessoas e o meio, analisando materiais descartados, encenando e inventando pequenas peças e colhendo objetos, como relata Michael Chapman:

Eu costumava sair cedo da casa Balls Pond Road para caminhar pelas ruas de Londres, apanhando qualquer coisa interessante que achava no caminho. Estes formavam uma mistura de objetos descartados - uma vara de bambu, calota brilhosa, lanterna chinesa, borracha velha, cerca de arame achado na sarjeta, uma batata e algumas ervas. Eu discutia as implicações estéticas e metafóricas destes materiais com as pessoas na rua, ao passo que experimentava, juntava e prendia as coisas até chegar a um objeto novo. Foi assim que criei o Blongenblattfahrtfanfuerez, um cajado para marchar, desenhado na revista "Daily Liar"180

Michael Chapman antes mesmo de integrar o Exploding Galaxy já realizava deambulações urbanas, bem ao modo Situacionista, como ele mesmo conta: "gostava de inventar meios alternativos para explorar as cidades como forma de conhecer bairros e arquiteturas que de outra forma ficariam desconhecidas", ampliando as

178 Szcelkun, Stefan. (Stefan Szcelkun ao recordar o Exploding Galaxy em 2001) disponível em http://www.stefan-szczelkun.org.uk. apud. Chapman, Michael. entrevista concedida à autora em julho de 2012 .

179 Michael Chapman em entrevista concedida à autora em julho de 2012.

180 idem. 
possibilidades de novas vivências. Seus trajetos eram sempre imprevisíveis, "uma técnica era de jogar uma moeda para determinar o caminho"181.

O Exploding Galaxy agregava diversas atividades às suas deambulações, apropriando-se dos espaços da cidade para a construção de poemas, enquanto os poemas serviam como roteiro para as apresentações públicas com caráter de Performance (dança dramática, poesia, assemblage, vestimenta, filosofia, canto, desenhos, textos, discussões), colhendo objetos na rua, investigando e ressignificando os objetos e os comportamentos sociais, investigações chamadas de explorações transmídias pelo grupo ${ }^{182}$.

As explorações transmídias envolviam a relação entre objeto e homem, entre homem e espaço urbano, e poderiam ocorrer na própria casa em que viviam, nas ruas, em fábricas abandonadas, prédios públicos ou nos parques londrinos. Nessas explorações transmídias, objetos comuns do cotidiano transformavam-se em suportes metafóricos. Os eventos em espaços abertos como parques eram propício para a relação dinâmica que pretendiam estabelecer com o espectador.

Lembro de uma ocasião quando, num bairro de Londres, descobrimos uma fábrica de tintas abandonada. Entramos num mundo novo e fantástico, altas salas, janelas quebradas, a geometria do espaço industrial estourado, tintas jogadas pelas paredes sobre o chão. Antigo maquinário, sujeira e cor, ambientação - sensações nos exaltaram a cada descoberta. Pensamentos e imagens anotados às pressas. Colheita de materiais e objetos.... 183

Entretanto, o estilo de vida e as atividades desenvolvidas pelo Exploding Galaxy eram mal vistos pela vizinhança, pela imprensa popular e pela polícia ${ }^{184}$. O

\footnotetext{
181 idem.

182 idem.

183 idem.

184 Paul Keeler publicou na época um livro intitulado "Planted" onde apreenta e coloca todos os documentos de como a polícia forjou um, aliás, vários flagrantes de maconha na Balls Pond Road, 99. Hélio conta a história deste livro em carta a Rubens Gerchman dizendo que além de fotos incríveis, indicando o sentido experimental do grupo, suas realizações: "só uma pessoa muito louca poderia ter feito este livro, pois ele coloca tudo: desenhos dos flagrantes, textos das audiências nos tribunais, tudo em capítulos e o livro em forma grande e comprida, como se fora uma página de papel oficio ampliada (...)". in Oiticica, Hélio. Carta a Rubens Gerchman. Londres, 4 de janeiro de 1969. in Catalogue Raisonné n. doc. 0542.69.
} 
caráter marginalizado de suas ações, fez com que o grupo fosse diversas vezes atacado verbal e fisicamente, perseguidos pela polícia e pelos noticiários sensacionalistas em jornais de grande circulação como o New of the World e The People. Essas perseguições ocasionaram a dispersão de seus integrantes e sua dissolução em 1969.

No Brasil, no final dos anos 1960, a repressão também determinou a atmosfera do país. Desde o golpe de Estado que levou os militares ao poder em 1964, manifestações espontâneas ou não que correspondiam à mera expressão de opinião, política e ideológica contrária ao governo, eram duramente reprimidas. Diversos artistas e intelectuais, manifestando-se com ideias contrárias, anárquicas e consideradas amorais, saíram 'de cena', seguindo forçados ou voluntariamente seus exílios, rumo a algum país da América Latina, Europa, Inglaterra ou EUA. E muitos deles experimentaram em seus exílios, a sensação de liberdade da qual não conheciam no Brasil 185.

Hélio Oiticica e seu amigo Torquato Neto embarcaram rumo à Londres num navio em 3 de dezembro de 1968. Antes mesmo de desembarcarem em terra firme, no Brasil era decretado o AI 5 (Ato Institucional no 5).

A viagem tinha objetivo certo, a montagem da exposição que Hélio faria na galeria Whitechapel na cidade de Londres. Os contatos que antecederam a exposição de Hélio na Whitechapel remontam ao ano de 1964, quando Guy Brett, crítico de arte do jornal The Times, Paul Keeler, então diretor da Signals, e Cristian Ledoux, colega de Guy Brett, visitaram o artista Sérgio Camargo em Paris, que comentou sobre a produção artística dos brasileiros Helio Oiticica, Lygia Clark e Mira Schendel. Esses contatos resultaram na exposição coletiva "Sounding Two", na galeria Signals, no ano seguinte, com a participação de um Bólide de Hélio, e trabalhos de mais 43 artistas, entre eles, Naum Gabo, Alejandro Otero, Jesus Rafael Soto, Takis, David Medalla, Henry Moore, Lygia Clark, Sergio Camargo, Alexander Calder, Kandinsky, Jean Arp, Pol Bury, Malevich, Lissitsky, Moholy-Nagy, Eduardo Chillida, Kurt Schwitters 186. No ano seguinte, Paul Keeler e Guy Brett, com o objetivo de cobrir a VIII Bienal de São Paulo, conheceram pessoalmente Hélio Oiticica. Nesta ocasião Hélio recebeu um

185 referência ao livro "Verdes vales do fim do mundo" de Antonio Bivar, que trata de seu exílio voluntário em Londres e de suas deambulações pela Inglaterra e Europa, no início da década de 1970, destacando a sensação de liberdade que experimentou em suas andanças longe da repressão brasileira.

186 "Metarmophosis, 1965: Glass Bólide by Hélio Oiticica". Artigo na Revista Signals Newsbulletins. Londres, vol. 1, n. 8. jun-jul, de 1965. in Catalogue Raisonné, n. doc. 0613.65. 
convite para expor na galeria Signals numa exposição individual (que acabou não acontecendo porque a Signal fechou antes), além da admiração de Guy Brett que dedicou um capítulo sobre os trabalhos de Hélio em seu livro Kinectic Art, lançado no ano seguinte, em 1966. Daí ao convite para expor na Whitechapel foram quatro anos. A Whitechapel Gallery era uma das maiores galerias de arte da Inglaterra, já tendo lançado Mondrian, Pollock, Rothko, entre outros, e para Hélio, expor lá representava, de fato, sua introdução no ambiente artístico internacional.

Sua estada em Londres, que deveria durar alguns meses até a exposição, durou um ano, "cheguei em Londres com dez dólares no bolso e fiquei um ano, não me pergunte como, porque é um mistério"187. Na verdade, Hélio chegou em Londres e deparou-se com o ambiente comunitário, hippie e artístico que exalava do Balls Pond Road, n. 99, identificando-se de imediato com aquele grupo de jovens que faziam "lindas experiências de arte na rua"188, experiências sensoriais, com a participação do espectador, etc. ${ }^{189}$. Em 11 de janeiro de 1969, Hélio e Torquato Neto mudaram-se para a residência que abrigava o pessoal do Exploding Galaxy, indo morar no quarto que também já tinha sido de David Medalla, que naquele momento fazia uma viagem à Índia com Michael Chapman. De todo o pessoal do Exploding Galaxy, Hélio ficou bastante próximo do poeta Edward Pope, com quem tinha "grande afinidade", e quem também, Mário Pedrosa considerava na época o maior poeta inglês vivo ${ }^{190}$.

Entretanto, a vida cotidiana na Balls Pond Road, n. 99, a falta de energia elétrica, de telefone, configurou um verdadeiro empecilho para Hélio manter-se na casa, já que tinha pela frente um trabalho árduo, com todos os encargos e compromissos que demandavam dos preparativos para a exposição na Whitechapel. Esta situação fez com que Hélio permanecesse pouco tempo no mesmo endereço, mudando-se para a casa de Mark Glazebrook, que havia assumido na época a diretoria da Whitechapel Gallery, onde encontrou condições suficientes, para enfim, encaminhar

\footnotetext{
187 Oiticica e Capinam. (Entrevista em O Pasquim, "Capinam e Oiticica" realizada por Martha Alencar, Paulo Francis Sérgio Cabral, Nelson Motta e Flávio Rangel). Jornal O Pasquim, Rio de Janeiro, 6 a 12 de agosto de 1970. Catalogue Raisonné, n. doc. 1835.70.

188 Oiticica, Hélio. Mangueira e Londres na rota, Hélio propõe uma arte efetiva. (entrevista de HO a Norma Pereira Rêgo). Jornal Última Hora, Rio de Janeiro, 31 de janeiro de 1970. in Catalogue Raisonné n. doc. 0869.70 .

189 Oiticica, Hélio. Hélio Oiticica. Entrevista de HO a Luis Antonio Pires. Jornal O Jovem, Rio de Janeiro, 6 de março de 1970. Catalogue Raisonné, n. 0871.70.

190 Oiticica, Hélio. Carta a Amilcar de Castro. Londres, 10 de março de 1969. in Catalogue Raisonné n. doc. 0688.69.
} 
os preparativos para a exposição. Posteriormente, ainda morou na casa de Jill Drower, também integrante do Exploding Galaxy.

Com o Exploding Galaxy, Hélio vivenciou explorações transmídias, colhendo detritos enquanto deambulava pelas ruas de Londres. Em carta a Lygia Clark, ele comenta sobre a estética dos detritos colhidos numa deambulação realizada junto a Edward Pope

Edward trouxe algum lixo para cá, e tem um material, espécie de juta laranja, que disse a ele você adoraria, por isso separei para lhe dar - puxa, como estou louco para voltar ao Rio, pois lá podia catar coisas e levar pra casa, ao passo que aqui tenho que fazer um pouco às escondidas! Ontem eu e Edward nunca vimos tanto lixo genial pelas ruas $^{191 .}$

As deambulações e a busca por detritos pelas ruas foram incorporados como atividade cotidiana na vida de Hélio durante sua estada em Londres. Uma imagem registrada por Michael Chapman, por exemplo, revela Hélio Oiticica e Mário Pedrosa catando lixo nas ruas de Londres.

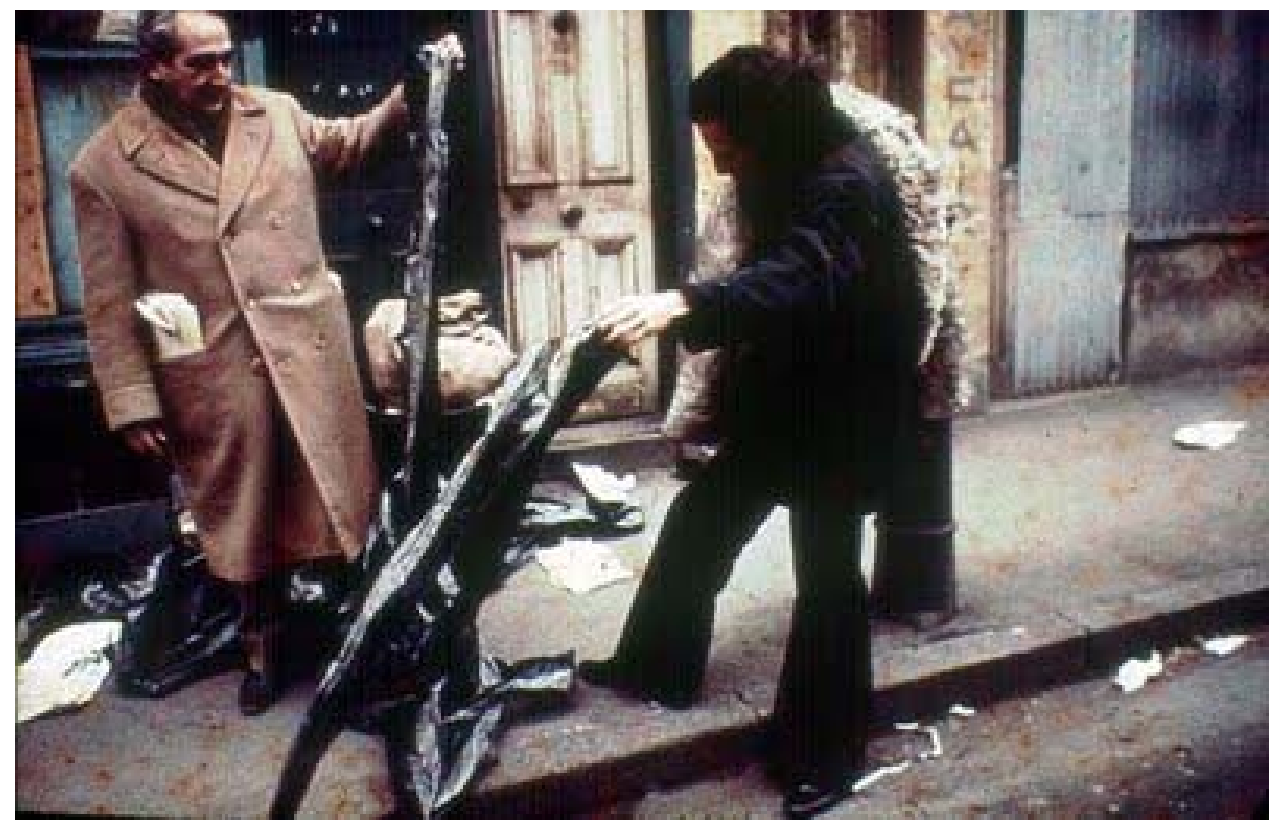

Figura 14 Mário Pedrosa e Hélio Oiticica colhendo detritos nas ruas de Londres, final dos anos 1960. Arquivo Michael Chapman.

191 Oiticica, Hélio. Carta a Lygia Clark. Londres, 20 de junho de 1969. Catalogue Raisonné n. doc. 0826.69. 
Em agosto de 1969, Hélio Oiticica, Michael Chapman, Edward Pope, Jill Drower, entre outros integrantes do Exploding Galaxy, empreendem uma deambulação pelas ruas londrinas sob efeito da mescalina, cujo registro Hélio apresenta no texto Londocumento ${ }^{192}$. Este texto é importante para se entender o espírito errante de Hélio naquele momento. Nele, inicia suas reflexões apontando: "não tenho lugar no mundo", para em seguida debruçar-se sobre "os mistérios de Londres" quando "o infinito de ruas e casas se fecham"(...). Nesta realidade, na qual "o frio, o conforto 'supercivilized', e a noite tantanteiam os tambores mentais", Hélio busca o Crelazer, exemplificando experiências que lhe proporcionaram tal vivência: almoço com Gilberto Gil em um restaurante macrobiótico, visita ao Arts Lab193 junto a Nelson Motta e Mônica, ouvir Edgar Varèse com Graham194 e Murdel ${ }^{195}$. Porém, sentado junto à estátua de Eros (Deus grego do amor, filho do Caos), já ao fim da deambulação, frisa a efemeridade dessas experiências, "penso", "vivo mais", mas é "um minuto entre o cá e o lá"196. Hélio contesta esta efemeridade, deseja um mundo menos opressivo para que o Crelazer deixe de ser algo marginalizado e passe a ser parte integrante da vida:

pode estar marginalizado agora, mas, estou certo de que não o será para sempre assim, desde que as aspirações humanas estejam livres da alienação de um mundo opressivo, não como uma dessublimada e falsa atividade, mas uma verdadeira que desmistifique e transforme internamente ${ }^{197}$.

192 depoimento de Michael Chapman à autora, julho de 2012.

193 Em carta a Rubens Gerchamn, Hélio conta sobre o Arts Lab: "O Arts Lab me impressionou, nos primeiros dias, mas depois descobri que há muito de "fashion" nos que frequentam lá: todos vão para mostrar que são mais loucos que outros, entende? Mas, mesmo assim, o pessoal é de matar: cabelos, roupas, etc., inacreditáveis e, a primeira vez que fui lá, topei logo com John Lennon pela frente, pois ele e a Yoko estão sempre lá. Vimos um filme do Bob Dylan, que tem o início genial mas depois cai no já conhecido, e para isso deitam-se em colchões, como se estivéssemos na praia. Bacana". in Oiticica, Hélio. Carta a Rubens Gerchman. Londres, 4 de janeiro de 1969. Catalogue Raisonné n. doc. 0542.69.

194 Graham Stevens, artista plástico que Hélio conheceu em Londres por intermédio de Paul Keeler. Graham fazia na época "uns sacos insuflados de ar, onde as pessoas como que mergulham e se envolvem no ambiente", comenta Hélio em carta a Rubens Gerchman. Londres, 4 de janeiro de 1969. in Catalogue Raisonné n. doc. 0542.69.

195 Oiticica, Hélio. Londocumento. Londres, 27 de agosto de 1969. Catalogue Raisonné n. doc. 0304.69.

196 Oiticica, Hélio. Londocumento. Londres, 27 de agosto de 1969. Catalogue Raisonné n. doc. 0304.69.

197 Oiticica. Hélio. Texto sobre o Éden. (Local não identificado), 25 de fevereiro de 1969. Catalogue Raisonné n. doc. 0365.69-a 
É durante sua vivência londrina que Hélio desenvolve o conceito de Crelazer198. O contato com o grupo Exploding Galaxy foi fundamental para a elaboração do Crelazer, o prazer de criar no lazer, de vivenciar um lazer criativo, um lazer não repressivo. Segundo Hélio, "a expansão do lazer do EXPLODING GALAXY de Londres não se reduz à busca da meditação plàmística (sic), mas como um "desenrolar da vida", que não é uma nova moral, mas um ou o crelazer" 199.

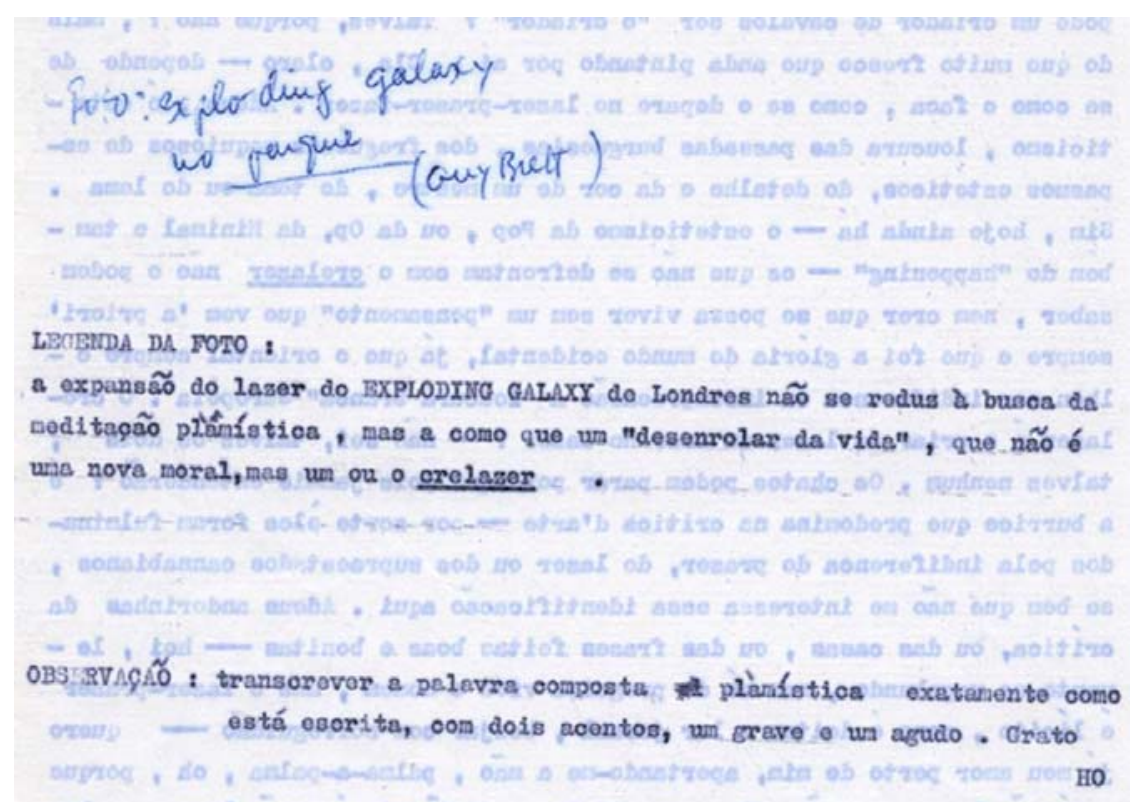

Figura 15 Nota no verso do texto Crelazer de Hélio Oiticica, Londres, 14 de janeiro de 1969. Catalogue Raisonné n. doc. 0367.69

Em carta a Lygia Clark, naquele mesmo ano (1969), Hélio retoma o significado de Crelazer ao se referir a um novo comportamento artístico e pessoal que o distanciava de pensamentos corruptos, opressivos, pautados na competição. Segundo Hélio esses 'sentimentos' não fazem parte de algo essencial do homem, representam apenas um estágio: "quem precisar da competição para 'fazer algo', está fora do que quero; pertence à categoria capitalismo-opressiva que se precisa eternamente envolver em competição "por dinheiro", que é a única justificável, nesse caso"200. Nesta categoria capitalismo opressiva, Hélio inclui o 'objeto-arte vendável' como algo do

198 o primeiro texto registrado sobre o Crelazer, data de 14 de janeiro de 1969. in Catalogue Raisonné n. doc. 0367.69 .

199 Oiticica, Hélio. Texto de HO sobre Crelazer. Londres, 14 de janeiro de 1969. Catalogue Raisonné n. doc. 0367.69.

200 Oiticica, Hélio. Carta a Lygia Clark. Londres, 7 de junho de 1969. in Catalogue Raisonné n. doc. 0822.69 . 
passado: "objeto-arte não existe mais para mim". Este novo comportamento, como frisa Hélio, deve ser integral,

que exclua toda sorte de ideia corrupta, pequenas do "mundo de arte", classe social (diferenças), intolerância com pessoas nas relações, etc. Hoje não excluo ninguém, a não ser as pessoas que automaticamente se excluem por serem opressivas; quero de verdade uma transformação total das coisas, fundamentada no comportamento individual; tudo o mais é infantilidade e mesquinharia, vedetismo, intelectualismo excessivo, preconceito burguês.

Esta integralidade Hélio pôde experimentar junto ao Exploding Galaxy (vivência semelhante já havia tido junto à comunidade da Mangueira). O ambiente do Exploding Galaxy, segundo Hélio, possui o caráter "ambiente-recin-total", onde vida e obra não se separam:

A casa onde vivem, que pode não ser só aquela mas será a que houver por onde quer que andem, tem esse caráter de um ambienterecin-total - até a comida, o comer, o vestir, o ambiente em si, mostram que lá com eles a vida e a obra não se podem separar (...) Não há que dizer que suas manifestações nos parques de Londres ou Amsterdã, ou por onde mais andarem, sejam a obra, ou uma forma dela - não seria exato: é que tudo é manifestação, mesmo as omissões do cotidiano, seus atos falhos, ou a fraqueza de se aguentar a vida, talvez porque o sentido comunitário com que se geraram, nisso, empreste a necessária integridade para tal 201 .

O ambiente comunitário e a experiência da 'totalidade' acabou por dar o caráter da própria exposição Whitechapel, da montagem no espaço da galeria aos ambientes, onde criou um "contexto para o comportamento, para a vida". Hélio definiu a montagem da Whitechapel, como uma "experiência galáxica". A montagem contou com a ajuda de cerca de vinte artistas. Um espaço de $30 \mathrm{~m}$ x $15 \mathrm{~m}$ e pé direito de $5 \mathrm{~m}$, que abrigou uma série de proposições que conformaram um percurso para "um enorme

201 Salomão, Waly. Hélio Oiticica: qual é o Parangolé e outros escritos. Rio de Janeiro: Rocco, 2003, p. 83. 
caminhar", constituindo num "ambiente total com formas de participação diversas desde as primeiras experiências na época neoconcreta, até o Éden 202.

Foi preciso colocar lá 27 toneladas de areia, uma célula cheia d'água, armar os ninhos-lazer onde as pessoas ficavam sentadas pensando ou simplesmente convivendo. Foi uma experiência bacana ver homens de negócios entrarem no recinto e obedecer a sugestão de tirar os sapatos para poder sentir as sensações táteis que o meu trabalho queria transmitir. Aqui no museu ninguém tira o sapato que o ato de tirá-lo é assim como o de abandonar um "status"'"203.

Hélio também levou sua 'experiência total' para o dia da inauguração (25 de fevereiro), vestindo-se com uma roupa que havia sido idealizada por Guilherme Araújo e executada por ele mesmo a partir de sobras de materiais utilizados na exposição. Hélio vestia uma calça preta boca de sino, feita de resto do pano utilizado para a cortina que separava a Sala de Bilhar, paletó curto e apertado de plástico brilhante branco, feito de resto do plástico da Cabine de Água, por baixo, colado ao corpo, um véu branco, feito de resto do véu de nylon dos Ninhos; além disso colares de candomblé e macumba aos montes e pulseira à "la Caetano".

A Whitechapel Experience representou para Hélio o "limite de tudo", fazendo latejar a vontade de desenvolver "cada vez mais algo que fosse extra-exposição, extraobra, mais do que o objeto participante, um contexto para o comportamento, para a vida". A experiência em Londres fez Hélio refletir sobre o caráter criador, ligado ao ambiente livre, não repressivo. Porém, mais do que isso, seu 'exílio' também lhe permitiu pensar a respeito do caráter criador existente na condição underground. Neste sentido, Hélio considerou seu exílio voluntário não como "forma ou folclore", mas como uma "necessidade de expandir para fora, de comunicar num nível internacional o que é o Brasil universal já em si". Esta posição, que englobaria ainda outros artistas brasileiros exilados que buscaram uma comunicação em 'grande escala', como Caetano

202 Oiticica, Hélio. "Hélio Oiticica". (Entrevista a Luis Antonio Pires). Jornal O Jovem, Rio de Janeiro, 6 de março de 1970. in Catalogue Raisonné n. doc. 0871.70.

203 Oiticica, Hélio. "Mangueira e Londres na rota, Hélio propõe uma arte efetiva". Entrevista a Norma Pereira Rêgo. Jornal Última Hora, Rio de Janeiro, 31 de janeiro de 1970. in Catalogue Raisonné n. doc. 0869.70. 
Veloso e Gilberto Gil, e que contribuíram na construção de uma "imagem Brasiltotal" 204 .

Em 1970, Hélio retorna ao Rio de Janeiro onde permanece por menos de um ano, quando por conta da Bolsa da Fundação Guggenheim, muda-se para Nova Iorque, cidade na qual vive até 1978, e lugar no qual falava que poderia "respirar". Depois de suas experiências em Londres, chegando ao 'limite' de tudo, Hélio busca agora "experiências-comunal (...), mais universal e mais difícil", não estava mais preocupado em realizar exposições, como comenta em carta à Lygia Clark: "encerrei minha época de fundar coisas para entrar nessa bem mais complexa de expandir energias, como uma forma de conhecimento "além da arte"; expansão vital, sem preconceitos ou sem querer "fazer história", etc. No que vai dar não sei; mas também há dez anos não sabia no que dariam as primeiras coisas 'ambientais"'205. Em Nova Iorque, Hélio queria "começar tudo do zero", uma "nova vida" que iniciaria pela escolha da sua residência, almejava "um lugar grande e vazio", onde ele pudesse "criar um ambiente pra viver": "quero fazer logo lá alguns filmes: não me interessam se sejam obras ou não"206.

204 Oiticica, Hélio. Carta a Nelson Motta. Brighton, 29 de novembro de 1969. in Catalogue Raisonné n. doc. 0994.69.

205 Oiticica, Hélio. Carta para Lygia Clark. Brighton, 23 de dezembro de 1969. Catalogue Raisonné n. doc. 1000.69.

206 Oiticica, Hélio. Carta para Lygia Clark. Rio de Janeiro, 19 de outubro de 1970. Catalogue Raisonné n. doc. 0662.70 . 


\subsection{A Deambulação de HO em Nova lorque}

São 4:15 pm em babilônia. o sol já se põe. uns quarenta e tantos fahrenheit $\left(4^{\circ}\right)$. (...). a euforia nas ruas, a mesma de sempre: a 2a. avenida não para: as cockettes que estrearam domingo passado aqui no anderson theatre (quase em frente daqui) desfilam escandalosamente travestidas com roupas incríveis: a estreia foi hollywoodesca, com tapete vermelho na calçada e mil fotógrafos; john lennon ia com jodorowski mas não apareceram, mas angela lansbury estava lá, alexis smith, etc.: all the underground also: loucura total aqui $^{207}$.

Em Nova Iorque, Hélio instala-se na $2^{a}$ Avenida, n. 81, loft 4, "pequeno e caro", porém, 'a dois passos' do Fillmore East, casa de shows que entre 1961 e 1971 foi palco de concertos dos maiores astros de rock da época, conhecido como A Igreja do Rock in Roll. No Fillmore East, Hélio assistiu a diversos shows, como de Taj Mahal, Chambers Brothers, Eric Burdon \& War, Quicksilver Messenger Service, Frank Zappa, Jethro Tull, B. B. King, Alice Cooper, Lee Michaels, Procol Harum, Byrds, Johnny Winter e Edgar Winter, Bloodrock, Ten Years After, Stephen Stills, entre outros. Morava numa região "barra pesada + rock drug freaks", como ele mesmo a descreve: "às duas da madrugada e a loucura estava no auge: um cara com a cara prateada vestido de chinês em cima de um carro, pessoas avançando querendo dinheiro, uma menina cantando com violão seguida de freaks, gritos e correria..."208 Encontrava-se também muito próximo do Orpheum, cinema que promovia festivais

207 Oiticica, Hélio. Carta para Ivan Cardoso. Nova Iorque, 12 de novembro de 1971. in Catalogue Raisonné n. doc. 0848.71.

208 Oiticica, Hélio. Carta para César Oiticica. Nova Iorque, 6 de fevereiro de 1971. in Catalogue Raisonné n. doc. 1092.71. 
'incríveis', com sessões à meia noite ${ }^{209}$. Mergulhou no mundo do cinema. Comentou em várias correspondências da época o quanto estava impressionado com a nova fase de Godard, os filmes "são geniais, em tudo: Vento dell'este e Vladimir et rosa"210, "são filmes altamente políticos, intencionalmente panfletários, em que o problema da própria razão de fazer cinema é posto em questão todo o tempo"211. Iniciou o curso introduction to film production na New York University, e aspirava fazer curso de vídeo-tapes, (cada dia abria um lugar novo para projeção de vídeo-tape experimental em Nova Iorque). Comprou uma Super 8 e transformou seu próprio loft em 'cinema', chamou de babylonests, que deveria "mudar e remudar de aparência conforme um comportamento-cinema"212. Construiu dentro de seu apartamento ninhos que serviam "para morar e viver". Queria transformar os ninhos teoricamente num meio de vida crelazer: "aqui vamos ter para se ver inside, ler, dormir, odaliscar e discutir: o mito de aninhar-se"213, escreve certa vez em carta a Caetano Veloso.

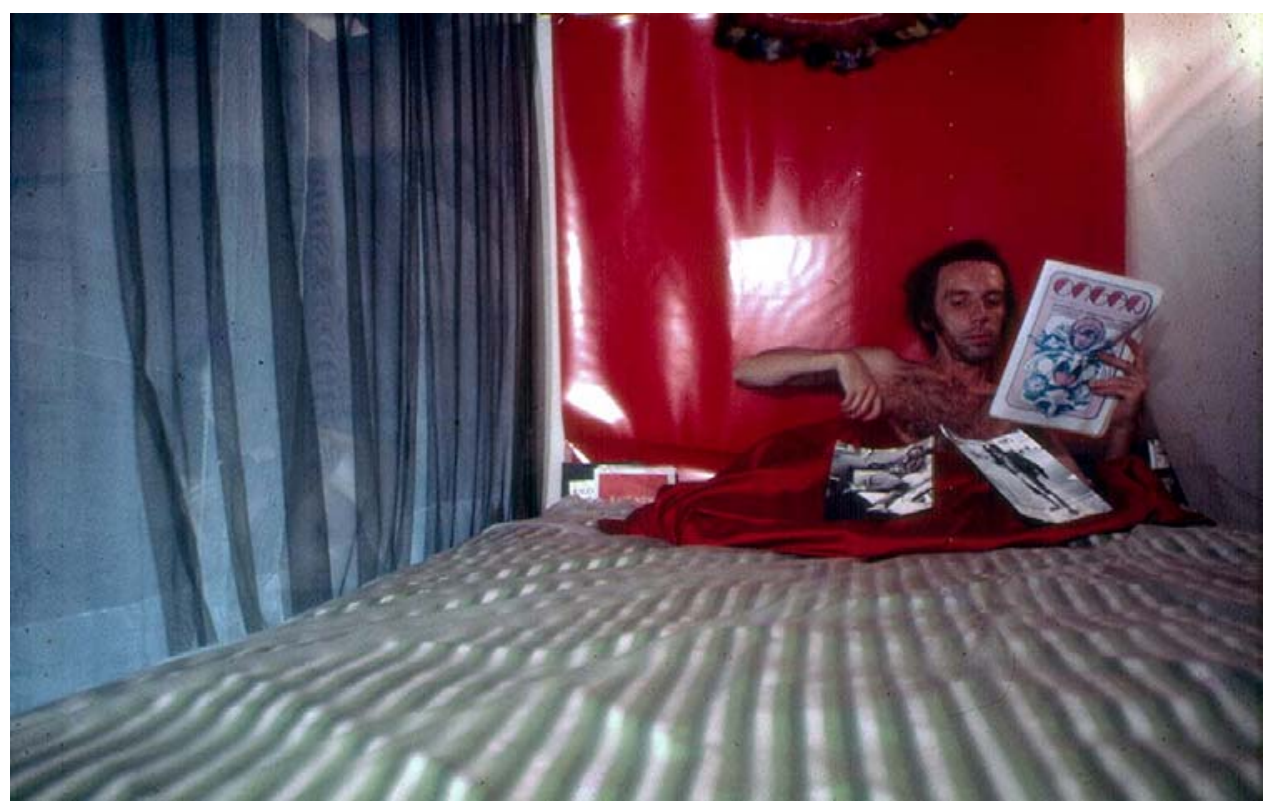

Figura 16 Hélio Oiticica num Ninho (Babylonests) em seu apartamento em Nova Iorque, 1971.

209 Oiticica, Hélio. Carta para Luciano Figueiredo. Nova Iorque, 25 de junho de 1971. Catalogue Raisonné n. doc. 1152.71.

210 Oiticica, Hélio. Carta para José Carlos Capinam. Nova Iorque, 25 de junho de 1971. Catalogue Raisonné, n. doc. 1151.71.

211 Oiticica, Hélio. Carta para Geraldo Sievers (Gerald Thomas).. Nova Iorque, 8 de junho de 1971. Catalogue Raisonné n. doc. 1146.71.

212 Oiticica, Hélio. Carta para Caetano Veloso. Nova Iorque, 8 de março de 1971. Catalogue Raisonné, n. doc. 1099.71.

213 idem. 


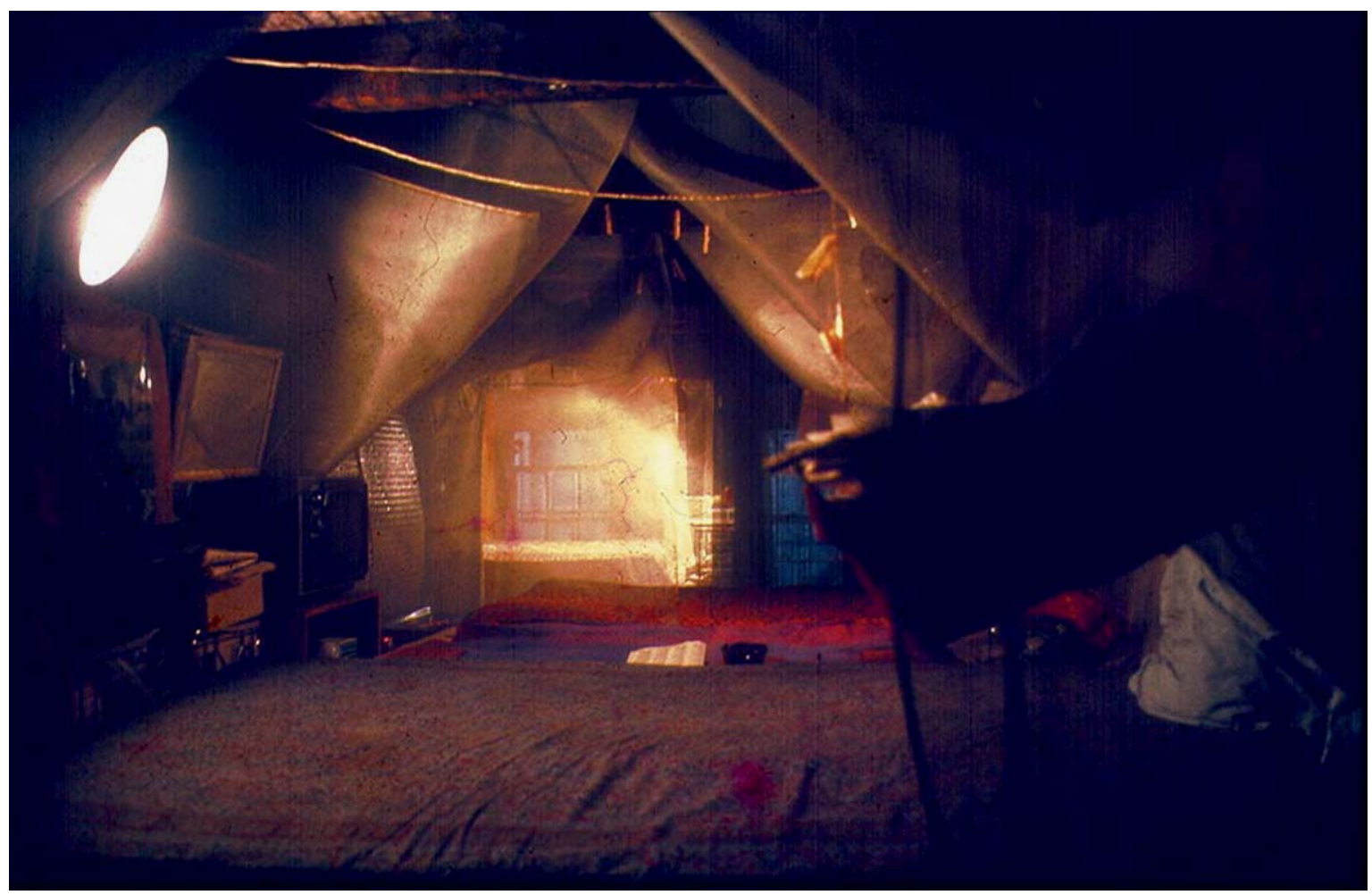

Figura 17 Ninhos (Babylonests) no apartamento de Hélio em Nova Iorque, 1971.

Hélio fez parte em Nova Iorque de uma comunidade artística que gozava de uma liberdade enorme para desafiar e subverter qualquer paradigma existente no mundo da arte. Frequentou o loft de Jack Smith, cineasta underground, que usava "drag actors", (o primeiro a utilizar atores drag queens no começo dos anos 1960), conheceu o pessoal do Theatre of the ridiculous, de Charles Ludlam, ficou amigo de Leandro Katz (era seu vizinho no loft do andar de cima ${ }^{214}$ ), do ator mexicano Mario Montez, do cineasta Ira Cohen, dos artistas Lee Jaffe, Gordon Matta-Clark. Morava a apenas 15 minutos da Greene Street, n. 112, que fica na região do SoHo, endereço que Jeffrey Lew com a colaboração de Matta-Clark transformou na primeira galeria coorporativa, aberta para todos aqueles que quisessem expor suas obras. A Greene Street n. 112 converteu-se num importante ambiente artístico, além de ponto privilegiado de convívio social 215 . Frequentou muitas festas 'de superstars', como uma na casa do Robert Rauschenberg, outra de Andy Warhol, comenta Hélio: "estavam todos lá:

214 Oiticica, Hélio. Carta para Lygia Pape. Nova Iorque, 26 de outubro de 1971. Catalogue Raisonné n. doc. 0855.71.

215 Crawford, Jane. Gordon Matta-Clark, uma comunidade utópica: o SoHo na década de 1970. in Gordon Matta-Clark Desfazer o Espaço. Catálogo de Exposição. Gabriela Rangel e Tatiana Cuevas (curadoria). Museu de Arte Moderna de São Paulo - MAM, 11 de fevereiro a 04 de abril de 2010. 
Taylor Mead, Candy Darling, etc.;) 216 . "Procurando-se acha-se: esta cidade tem o mundo todo!", escreve a Lygia Clark217.

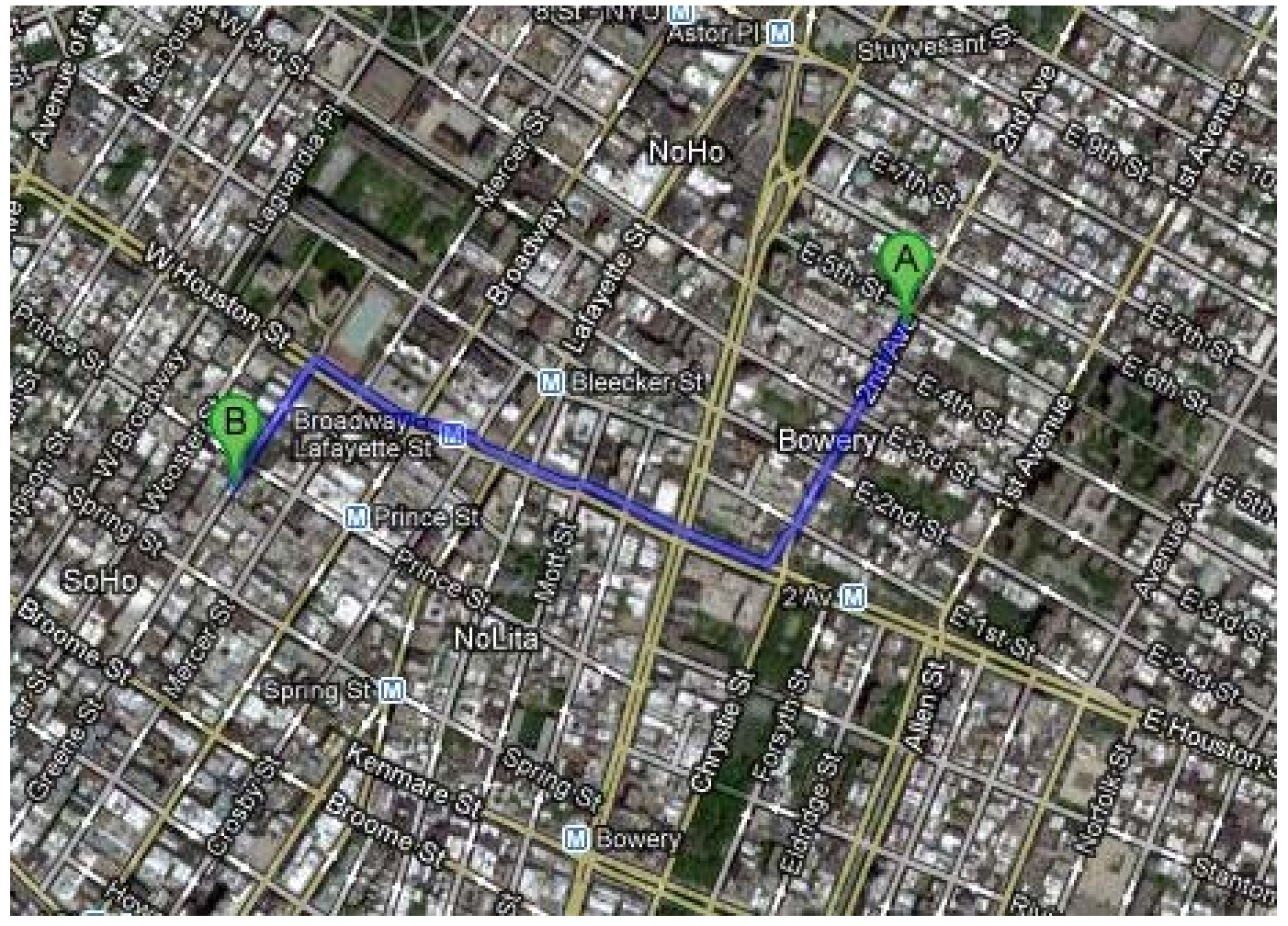

Figura 18 Localização Google Maps 218: A. 2a. Avenida, n. 81 e B. Greene Street, n. 112.

A partir da proximidade com Leandro Katz (que na época trabalhava como iluminador do Theatre of the ridiculous), Hélio começou a frequentar diversas festas em diferentes lofts. Em uma visita ao loft de Jack Smith em 1971, Hélio experienciou além de uma performance, que "parecia mais como se fosse um dos filmes dele ao vivo", uma apresentação de slides "incrível", que Hélio definiu como "um quasicinema": por conta dos cortes precisos na tela, "que extravasava pelo ambiente", pelo tempo de cada slide e pela escolha cuidadosa da trilha sonora. Esta expressão 'quasicinema' utilizada por Hélio para definir a apresentação de slides de Jack Smith, advinha do resultado destas apresentações, ou seja, muito próximo da "ideia que se tem de super 8", como explica em carta a Lfer 219 . "Quasi-Cinema" será o nome dado à

216 Oiticica, Hélio. Carta a Ivan Cardoso. Nova Iorque, 11 de maio de 1971. Catalogue Raisonné n. doc. 1117.71 .

217 Oiticica, Hélio. Carta a Lygia Clark. Nova Iorque, 14 de maio de 1971. Catalogue Raisonné n. doc. 1118.71.

218 https://maps.google.com.br/

219 Oiticica, Hélio. Carta para Luis Fernando Guimarães. Nova York, 11 de abril de 1971. Catalogue Raisoneé n. doc. 1107.71. 
série que incluirá as experiências em COSMOCOCA, projeto de filmes que Hélio desenvolveu junto a Neville D'Almeida em 1973.

Quanto à relação de Hélio com o artista Matta-Clark é difícil precisar sua origem. Poderia ter nascido do encontro em alguma das diversas festas-performanceexposição que acontecia cada dia em um $\operatorname{lotf}^{220}$, da proximidade de suas residências o loft 4 da $2^{\text {a }}$ avenida ficava apenas dez minutos da Chrystie Street, n. 131, onde localizava-se o loft de Matta-Clark -, ou por conta do boicote à Bienal de São Paulo em 1970, organizado por Matta-Clark em resposta à prisão dos trinta jovens arquitetos que propuseram soluções sociais aos problemas urbanos do Brasil, durante a ditadura militar do general Médici. Em carta aberta à Bienal de São Paulo, Matta-Clark escreve:

É de conhecimento público que a liberdade de expressão já não existe no Brasil, o que quer dizer que a Bienal e a livre comunicação naquele país foram condenadas à morte. [...] Em lugar de apoiar a causa do livre intercâmbio de informações públicas, os trabalhos expostos em São Paulo, vergonhosamente, darão importância a esse governo totalitário e aos seus aliados 221 .

220 Jane Crawford fala que como havia poucos bares na região era muito comum todos acabarem no mesmo lugar, "pois tinham a segurança de poder sustentar uma animada discussão crítica com seus colegas. As festas nos lofts também eram muito comuns", além de um "crescente aparecimento de uma série de lugares alternativos para performances, como The Kitchen e Artists Space". Crawford, Jane. Gordon Matta-Clark uma comunidade utópica: o SoHo na década de 1970. in Gordon Matta-Clark Desfazer o Espaço. Catálogo de Exposição. Gabriela Rangel e Tatiana Cuevas (curadoria). Museu de Arte Moderna de São Paulo - MAM, 11 de fevereiro a 04 de abril de 2010.

221 Carta aberta à Bienal de São Paulo, por Gordon Matta-Clark, 19 de maio, 1971. Catalogue Raisonné, n. doc. 1359.70. 


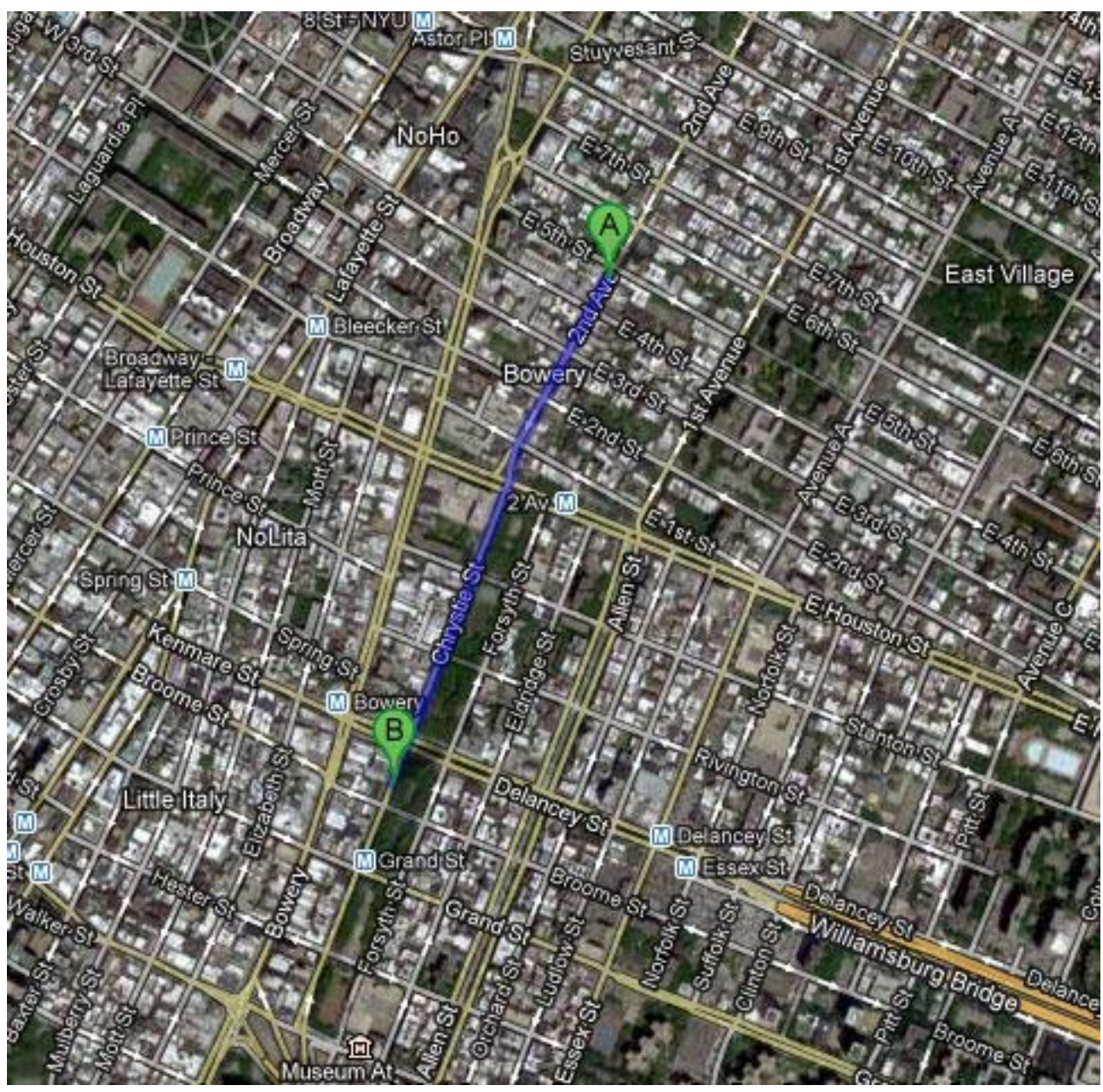

Figura 19 Figura 19 Localização Google Maps. A. Loft de Hélio e B. Loft de Matta-Clark.

Já amigo de Hélio, quando em 1972 Matta-Clark empreende uma viagem à America do Sul, junto com Jeffrey Lew, percorrendo Equador, Peru e Chile, envia-lhe um Cartão Postal de Machupicchu dando notícias de sua aventura: "Temos passado dias mágicos no vale Urrabamba, explorando cidades incas, estradas e cavernas funerárias - antes de Peru, Jeffrey Lew e eu fizemos peças para o Museu das Belas Artes em Santiago (...) Eu vi Mario P. ${ }^{222}$ por apenas alguns minutos, mas estarei de volta agora que vi a revolução. Talvez possamos ir com outros no próximo outono. Com amor, Gordon Matta Clark"223.

222 A data, a localização e a referência comum a Hélio, indica que seja Mário Pedrosa, crítico de arte brasileiro, amigo de Hélio, que neste período, por conta da situação política no Brasil, refugiava-se no Chile.

223 Tradução livre. Cartão original de 17 de Janeiro de 1972. in Catalogue Raisonné n. doc. 2520.72 


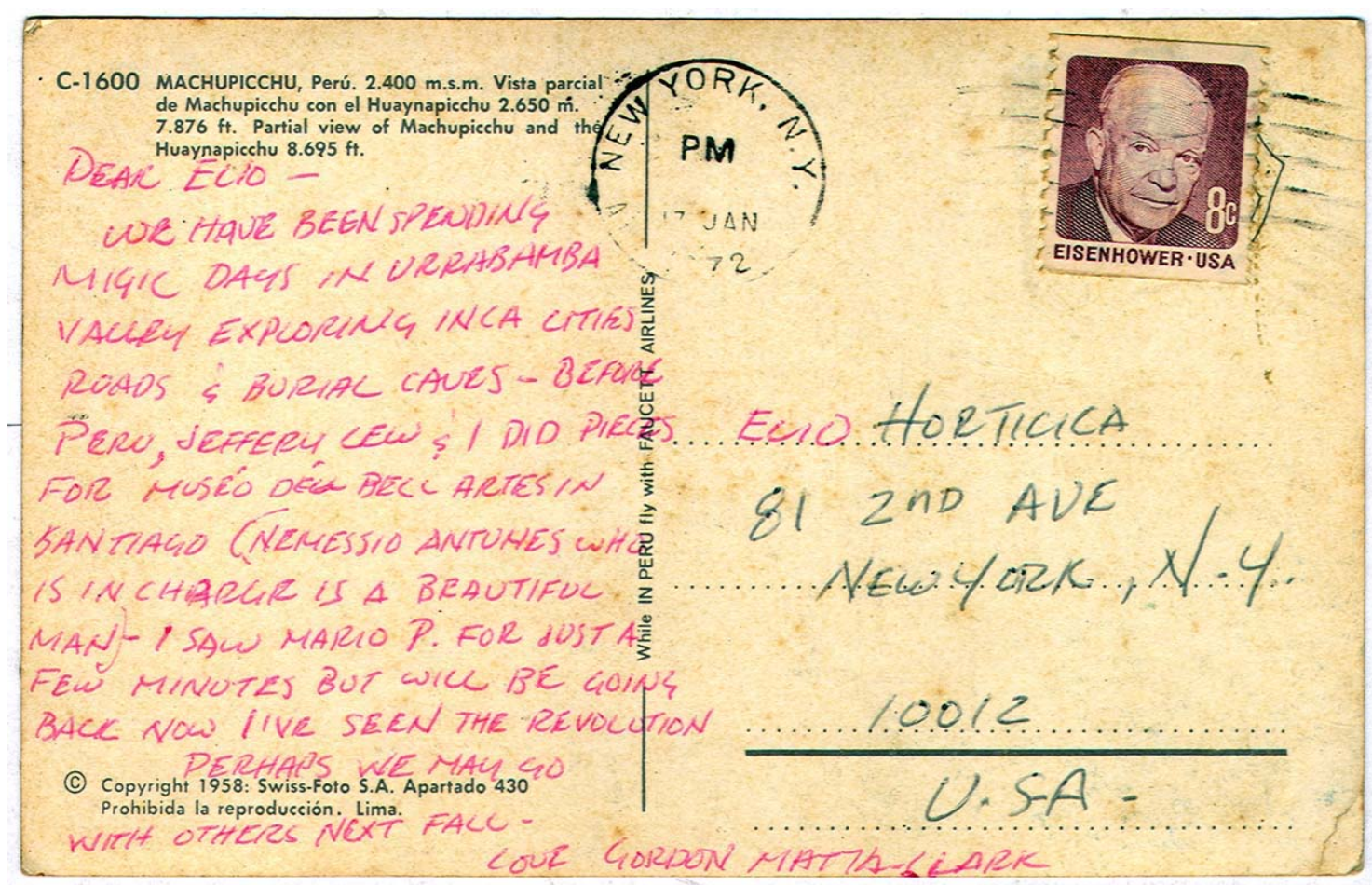

Figura 20 Cartão Postal de Gordon Matta-Clark a Hélio Oiticica. Catalogue Raisoneé n. doc.

2520.72

Em oposição ao clima de repressão no Brasil, em Nova Iorque Hélio encontra um ambiente favorável, um clima efervescente de artistas que compartilhavam a ideia de incorporar dinâmicas sociais como estratégia para integrar a arte à vida cotidiana. Por tanto, mais do que a proximidade geográfica entre Hélio e Matta-Clark vale considerar posições bastante similares, comuns a ambos e que os levaram a uma amizade que perdurará até a morte de Matta-Clark em 1978224, ano em que Hélio retorna ao Rio de Janeiro. O cartão postal enviado por Matta-Clark é um dos poucos registros que comprovam a relação de proximidade entre eles, ao mesmo tempo que se transforma num elemento potencial para refletirmos sobre suas afinidades.

Matta-Clark possuía um espírito nômade, "suas incursões pelo Equador, Chile, Peru, Haiti, México e Guatemala, revelam - além de uma vocação aventureira, que o levava a lugares de difícil acesso na época - o interesse habitual de um viajante que se

224 Lisette Lagnado encontrou nos arquivos de Hélio Oiticica uma lista manuscrita, datada de 9 de setembro de 1978, encabeçada por um lembrete: "1. Enviar um cartão para Jane Crawford (sobre a morte de Gordon Matta): 20E. 20th Street. New York, NY 10010". comentado em Lagnado, Lisette. Gordon Matta-Clark e Helio Oiticica: Micro-Histórias de Mitologias Contemporâneas. in Gordon MattaClark Desfazer o Espaço. Catálogo de Exposição. Gabriela Rangel e Tatiana Cuevas (curadoria). Museu de Arte Moderna de São Paulo - MAM, 11 de fevereiro a 04 de abril de 2010. 
dispõe a conhecer os lugares históricos e seus aspectos da vida cotidiana"225. Este espírito acaba refletindo na forma como Matta-Clark apropria-se do próprio espaço urbano, uma vez que considera que o espaço funcionalista da cidade moderna esquadrinha o próprio indivíduo. Vale considerar que Matta-Clark era arquiteto de formação, sua crítica à arquitetura moderna comparece de forma bastante direta em seu discurso: "A questão da arquitetura moderna [...] 'estilo internacional', 'era da máquina', 'arquitetura revolucionária', seja qual for o modo como se chame isso [...] é a seguinte: todas essas diversas ideologias aceitam o funcionalismo mecânico como uma espécie de vocabulário visual, sobre o qual elas podem moralizar em termos de necessidade inevitáveis"226. Soma-se à sua posição crítica, a própria crise econômica que enfrentava Nova Iorque nos anos 1970, que delineou o aspecto da cidade (edifícios abandonados, em ruína, entulhos, andarilhos nas ruas), e a própria dinâmica urbana, marcada pela lógica capitalista que convertia os espaços da cidade em territórios dominados por interesses comerciais e coorporativos. Neste contexto, de reordenação da cidade motivada por interesses imobiliários, o resultado é o desaparecimento da memória histórica e de modos de vida. Matta-Clark vivenciou de perto estes processos, vendo crescer a pobreza, os subúrbios e o abandono de regiões inteiras como os bairros do Brooklyn, Queens, Harlem e Bronx. E foi como um 'nômade urbano' que MattaClark passou a explorar as regiões abandonadas lançando luz para os espaços 'invisíveis' da cidade.

Em 1976, Matta-Clark converte-se numa "versão subterrânea do flâneur baudelairiano"227, empreendendo um passeio pelos espaços subterrâneos de Nova Iorque, colocando em evidência a variedade e a complexidade desses espaços subterrâneos na região metropolitana. Enquanto empreende sua expedição, MattaClark documenta essa experiência em vídeo intitulado Substrait (Undreground Dailies). Expedições semelhantes a essa, Hélio Oiticica empreenderia na cidade do Rio de Janeiro a partir de 1979, ao propor o Delirium Ambulatorium, uma deambulação em

225 Cuevas, Tatiana. Desfazer o espaço. in Gordon Matta-Clark Desfazer o Espaço. Catálogo de Exposição. Gabriela Rangel e Tatiana Cuevas (curadoria). Museu de Arte Moderna de São Paulo MAM, 11 de fevereiro a 04 de abril de 2010.

226 Matta-Clark, Gordon. op. cit. Rangel, Gabriela. Desfazer o Labirinto. in Gordon Matta-Clark Desfazer o Espaço. Catálogo de Exposição. Gabriela Rangel e Tatiana Cuevas (curadoria). Museu de Arte Moderna de São Paulo - MAM, 11 de fevereiro a 04 de abril de 2010.

227 Cuevas, Tatiana. Desfazer o espaço. in Gordon Matta-Clark Desfazer o Espaço. Catálogo de Exposição. Gabriela Rangel e Tatiana Cuevas (curadoria). Museu de Arte Moderna de São Paulo MAM, 11 de fevereiro a 04 de abril de 2010. 
que se apropriava principalmente de regiões abandonadas e deterioradas da cidade, numa série denominada Acontecimentos Poético-Urbanos, tema discutido na seção seguinte.

Entretanto, anterior a Substrait, Dumpster Duplex de 1972, também conjuga uma série de elementos que possibilita algumas reflexões. Trata-se de um grande contêiner industrial que Matta-Clark posicionou entre os números 98 e 112 da Greene Srteet para funcionar como um espaço aberto para a participação de artistas e transeuntes. O contêiner era um convite para o 'descondicionamento' social e a criação livre. Composto de portas divisórias de madeira recuperada de materiais de demolição, seu interior oferecia a experiência labiríntica do espaço, a partir de uma circulação interna articulada por chapas movediças. Seus amigos artistas eram convidados a participar filmando as experiências, num vídeo que foi intitulado Open House. Dumpster Duplex nos faz lembrar dos penetráveis labirínticos de Hélio, que oferece um percurso programado para uma experiência da participação e criação livre do sujeito comum. Outras aproximações também são possíveis, como a ideia de 'casa aberta' com a ideia do Babylonests ${ }^{228}$, já que ao construir ninhos' no interior de seu loft, Hélio quis também um espaço aberto a experiências coletivas.

228 Lisette Lagnado faz esta aproximação em Gordon Matta-Clark e Hélio Oiticica: micro-histórias de mitologias contemporâneas. in Gordon Matta-Clark Desfazer o Espaço. Catálogo de Exposição. Gabriela Rangel e Tatiana Cuevas (curadoria). Museu de Arte Moderna de São Paulo - MAM, 11 de fevereiro a 04 de abril de 2010. 

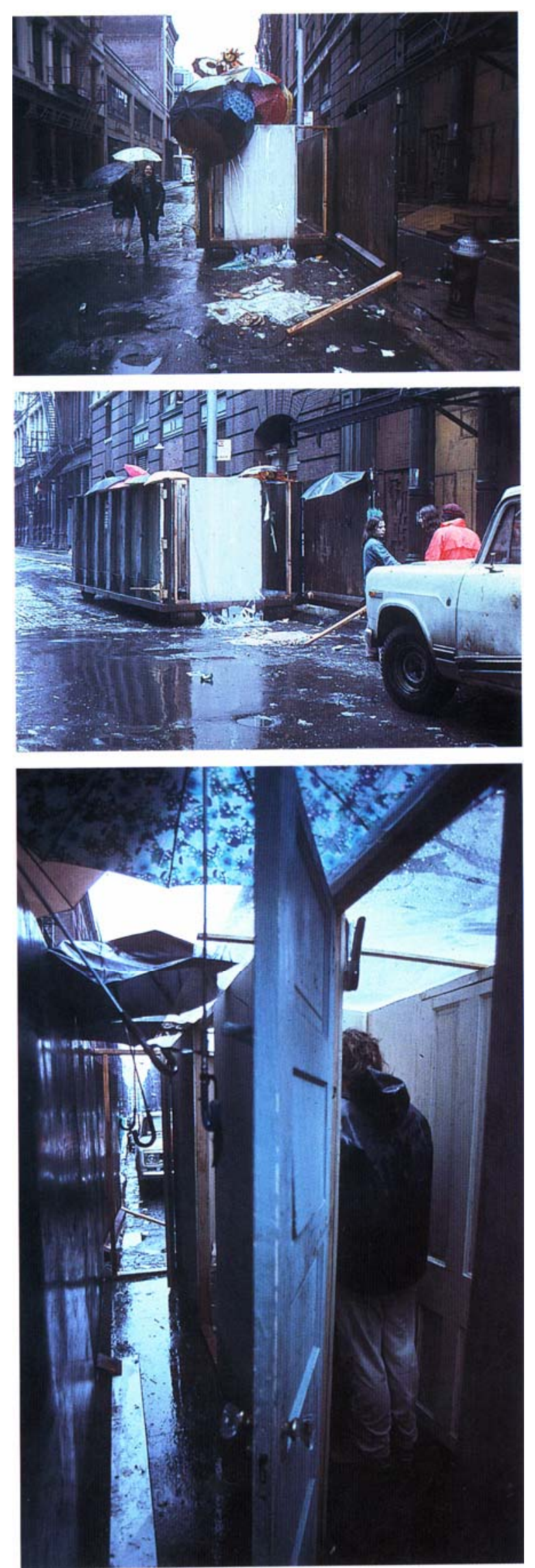

Figura 21 Open House. Greene Street, New York, 1972. in Gordon Matta-Clark 
Segundo Hélio Oiticica, Nova Iorque, the old babylon, era o contexto ideal para colocar em prática ideias já gestadas anteriormente. O contato com a comunidade artística ali residente e as novas leituras que realizava naquele período (What is a thing, do Heidegger, Society of the Spectacle de Guy Debord, Notations e Silence de John Cage, Understanding Media Mcluhan), também foram fundamentais para Hélio "reformular coisas" que o "perseguiam à doze anos", como ele mesmo comenta em carta a Mário Pedrosa 229 . Os Ninhos, por exemplo, que até então tinham sido apresentados apenas em Exposições, deveriam agora ser transformados em crelazer, espaço para um lazer criativo. Além disso, Hélio procura conjugar em seus trabalhos a ideia de um teatro, onde a plateia não exista a não ser como atores-volunteers e atoresspectators participators ${ }^{230}$. Essas ideias foram desenvolvidas quando Hélio ainda encontrava-se em Londres, porém agora era o momento para colocá-las em prática. Desta forma, propôs ao Jewish Museu de Nova Iorque uma exposição que se estenderia a um lugar aberto, que poderia ser o Central Park, exposição que nunca chegou a acontecer. Este projeto que ficou conhecido como Projeto Central Park representou uma retomada dos Penetráveis, porém assumiu o caráter de proposição para um "auto-teatro". Hélio o definiu como uma transformação da 'performance', pois conjuga performances planejadas, outras improvisadas em que as pessoas passariam por áreas de proposição para a transformação de comportamento: são labirintos complexos, em forma, por exemplo, de círculo, em que "há o processo labiríntico mais como um vai e vem de entradas com núcleos de participação-proposição, que desembocam numa área aberta de performance" 231 , descreve Hélio. Esses processos labirínticos são o meio de introduzir o 'performer' às diversas proposições, na maioria corporais (vestir, pintar o corpo, etc.) ${ }^{232}$, mas também, situações em que depara-se com alguém lendo por exemplo o minimanual de Carlos Marighella, sobre guerrilha urbana, ou com o Nu descendo a escada, de 1913 de Duchamp233.

229 Oiticica, Hélio. Carta para Mario Pedrosa. Nova Iorque, 31 de outubro de 1971. Catalogue Raisonné, n. doc. 0851.71.

230 Oiticica, Hélio. Carta para Caetano Veloso. Nova Iorque, 8 de março de 1971. Catalogue Raisonné, n. doc. 1099.71.

231 Oiticica, Hélio. Carta para Vera Pedrosa. Nova Iorque, 24 de julho de 1971. Catalogue Raisonné n. doc. 0961.71.

232 Oiticica, Hélio. Carta para Rogério Duarte. Nova Iorque, 13 de agosto de 1971. Catalogue Raisonné n. doc. 0914.71.

233 Essas referências Hélio comenta em diversas cartas datadas de 1971, em Nova Iorque. 
Semelhante ao projeto Central Park, Hélio idealizou um Penetrável para ser construído na Praça da República em São Paulo, o PN16: "minha obra mais importante da série dos projetos e se for realizado nada de melhor poderia acontecer" 234 . Hélio dedicou PN16 ao seu amigo Luis Fernando Guimarães (o Lfer), trata-se de um labirinto de $11 \mathrm{~m} \times 11 \mathrm{~m} \times 3 \mathrm{~m}$, uma caixa preta, com todas as paredes pretas, onde os participantes confrontar-se-iam com uma série de microfones pendurados e teriam que falar sobre a palavra: NADA (uma "palavra-tipo": uma "abstração, um conceito linguístico, é a palavra em "estado de dicionário" independente de qualquer situação"235). Hélio explica que PN 16 é um

exercício de estrutura não-espetáculo, não-ritualística e nãosignificativa: a evocação da palavra NADA deve estar isenta de qualquer conotação com conceitos metafísicos ou tentativas de interpretação - vale notar que nessa experiência há a intenção de que para o participante tudo o que for dito aos microfones seja absorvido na estrutura-situação geral sem resposta ou diálogo imediatos, o que não impede que tudo esteja sendo gravado fora e que seja estocado para uso futuro em outra experiência qualquer 236 .

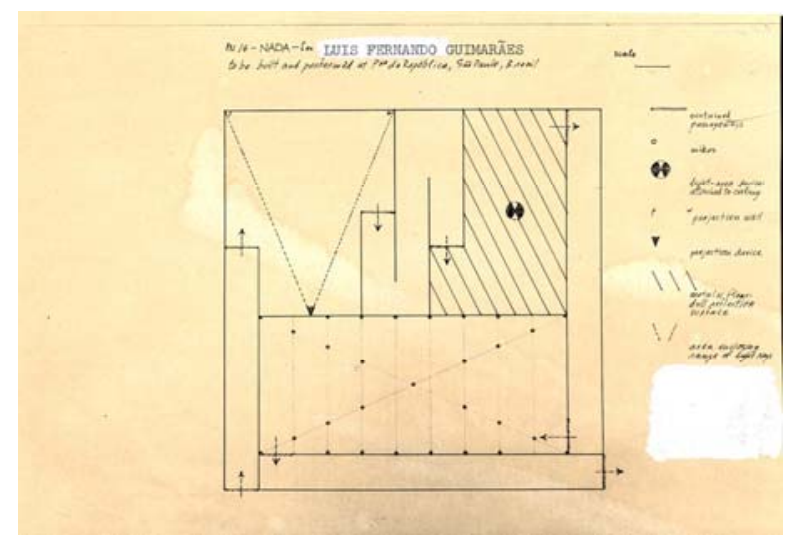

Figura 22 Planta do PN16-NADA. Catalogue Raisoneé n. doc. 0414.71

234 Oiticica, Hélio. Carta para Luis Fernando Guimarães. Nova Iorque, 30 de setembro de 1972. Catalogue Raisonné n. doc. 1294.72.

235 Oiticica, Hélio. - PN16: $4^{\circ}$ Projeto dos Subterranean Tropicália Projects. Nova Iorque, 4 de dezembro de 1971. Catalogue Raisonné n. doc. 0272.71.

236 Oiticica, Hélio. Sobre PN16. Nova Iorque, 1 de setembro de 1971. Catalogue Raisonné n. doc. 0413.71 . 
Hélio também procura neste período uma 'síntese' do Parangolé, que "nada mais é do que uma tentativa de descoberta e não re das CAPAS no que têm de importante: o que foi feito nada é diante do que é proposto: nada é limitado no tempo: mas simultâneo" 237. O Parangolé Síntese é resultado do processo de 'desmitificação', é o fim do display fragmentado: seria o que ele denominou como "aumentar o momento”, ou seja, "não elevá-lo à categoria de mito ou de preciosidade estética”. Hélio explica que nesta 'síntese', o que restou do Parangolé anterior foram as situações circunstanciais"238. Entretanto, enquanto o Parangolé, em 1964, requeria a participação corporal direta, e a dança significava a aspiração ao mito, nesta 'síntese', o Parangolé interessa enquanto liberação inventiva das capacidades de play: INVENÇÃO PLAY (PARANGOPLAY), não se trata mais da dança em seu estado naturalista, de manifestação humana nem reduções a ego-trip (fragmentação neuropsíquica) ${ }^{239}$. Antes o Parangolé era in-corporação a partir do mito, agora é clímax corporal, ou seja, não é mais o samba, mas o rock: “proposição corporal levada a um nível de experimentalidade aberta; absorção do tempo: fim do display fragmentado"240. Hélio tinha descoberto a partir do rock a liberdade do corpo na dança, da dança que se dança sozinho, pois, ao contrário do samba, o rock dispensa o estágio de iniciação:

foi com a Mangueira que eu descobri esse negócio que dança é a dança que se dança. A única diferença que há entre samba e rock é que no samba, você tem que ser iniciado nele, pra você poder usufruir dessa descoberta do corpo dançando sozinho. Agora, o rock dispensa esse estágio de iniciação. Ao passo que o samba é uma coisa ainda ligada à terra, ligada a coisas míticas das quais o rock prescinde. $O$

237 Oiticica, Hélio. Carta para Antônio Manuel. Nova Iorque, 28 de novembro de 1972. Catalogue Raisonné n. doc. 1324.72

238 Oiticica, H. Texto sobre Parangolé Síntese. Nova Iorque, 26 de dezembro de 1972. P1-5. In: Catalogue Raisonné, $\mathrm{n}^{\circ}$ doc. 0201.72.

239 Oiticica, H. Texto sobre Parangolé Síntese. Nova Iorque, 26 de dezembro de 1972. In Catalogue Raisonné, $\mathrm{n}^{\circ}$ doc. 0201.72. p.1-5.

240 Oiticica, H. Texto sobre Parangolé Síntese. Nova Iorque, 26 de dezembro de 1972. In Catalogue Raisonné, $\mathrm{n}^{\circ}$ doc. 0201.72. p.1-5. 
rock já sintetiza tudo isso, você já é iniciado desde que ele te atinge. $O$ samba eu tive que ir a ele. ${ }^{241}$

Em Parangolé-Síntese, Hélio explicita o problema do 'espectador', principalmente, do problema da participação do espectador "frente ao mundoespetáculo", o que ocasiona o dilema: "transformar-se ou ser consumido pelo contemplar: ser performer por iniciativa ou compelido a sê-lo: criar o circo ou ser objeto-espectador" 242.

Estas questões, que passam a figurar as proposições de Hélio, são fruto das reflexões sobre sua produção em termos de 'construção de situações', numa conceituação bastante próxima daquela da Internacional Situacionista. A 'construção de situação' definida pelos situacionistas diz respeito a uma "orientação realmente experimental" que "consiste em estabelecer, a partir de desejos reconhecidos com maior ou menor clareza, um campo de atividade temporária favorável a esses desejos"243, ideias estas que estão presentes não somente em seus Penetráveis labirínticos, Capas e Ninhos, mas em todo o programa ambiental Parangolé. Hélio tinha consciência desta proximidade, em carta à Luis Otávio Pimentel chega a afirmar que suas "experiências-situações" "possuem relações óbvias" com os situacionistas244, passando a referir-se às suas capas (parangolé) como capas-situação ${ }^{245}$. Por outro lado, os próprios situacionistas afirmam que todos aqueles que trabalham no intuito de construir situações são "de modo espontâneo ou consciente e organizado, présituacionistas, isto é, indivíduos que perceberam a necessidade objetiva dessa construção através de uma mesma sensação de carência da cultura e das mesmas expressões da sensibilidade experimental imediatamente anterior. Estão ligados por

241 Oiticica, H. Um mito vadio. Entrevista concedida a Jary Cardoso, e que estiveram presentes também Luís Fernando Guimarães, que tinha sido do grupo Oficina e o músico e compositor Jards Macalé. In Folhetim. São Paulo, domingo, 5 de novembro de 1978. (Catalogue Raisonné, $n^{\circ}$. doc. 0944.78-p1-2.)

242 Oiticica, H. Texto sobre Parangolé Síntese. Nova Iorque, 26 de dezembro de 1972. In Catalogue Raisonné, $\mathrm{n}^{\circ}$ doc. 0201.72. p.1-5.

243 IS. Questões Preliminares à Construção de uma Situação. IS, nº 1, junho de 1958.

244 Oiticica, Hélio. Carta para Luiz Otávio Pimentel. Nova Iorque, 5 de julho de 1971. Catalogue Raisonné n. doc. 0966.71

245 Oiticica, Hélio. Carta para Luciano Figueiredo. Nova Iorque, 19 de setembro de 1972. Catalogue Raisonné n. doc. 1292.72. 
uma especialização e por pertencerem a uma vanguarda histórica dessa especialização"246.

Hélio não só 'constrói situações' à maneira situacionista, propondo formas experimentais de um jogo superior, transformando o papel de 'público', senão passivo pelo menos de mero figurante à vivenciadores ${ }^{247}$, como está em total sintonia com a crítica a sociedade do espetáculo desenvolvida pelo líder da IS, Debord. Assim como em PN 16 e Parangolé-Síntese, em que Hélio propõe de forma explícita um exercício de estrutura "não-espetáculo", em 1972, essas ideias também aparecem conjugadas na proposta de um event (Hélio preferia chamar 'evento' a performance ${ }^{248}$ ) no qual Hélio intitula E PET C LO, em que omite as sílabas "s", "a" e "u" da palavra espetáculo: "que nada mais é do que a palavra ESPETÁCULO with dropped letters: a chave de tudo = o espetáculo não é espetacular $=$ o espetáculo é não-espetacular $=$ que você repete e inicia tudo", explica 249 .

246 IS. Questões Preliminares à Construção de uma Situação. IS, nº 1, junho de 1958.

247 Debord, Guy, Relatório sobre a construção de situações e sobre as condições de organização e de ação da tendência situacionista internacional. (Texto apresentado na conferência de fundação da Internacional Situacionista de Cosio d'Arroscio, julho de 1957).

248 Oiticica, Hélio. Carta para Haroldo de Campo. Nova Iorque, 25 de outubro de 1972. Catalogue Raisonné, n.doc. 1298.72.

249 Oiticica. Hélio. Carta para Luis Fernando Guimarães. Nova Iorque, 12 de outubro de 1972. 


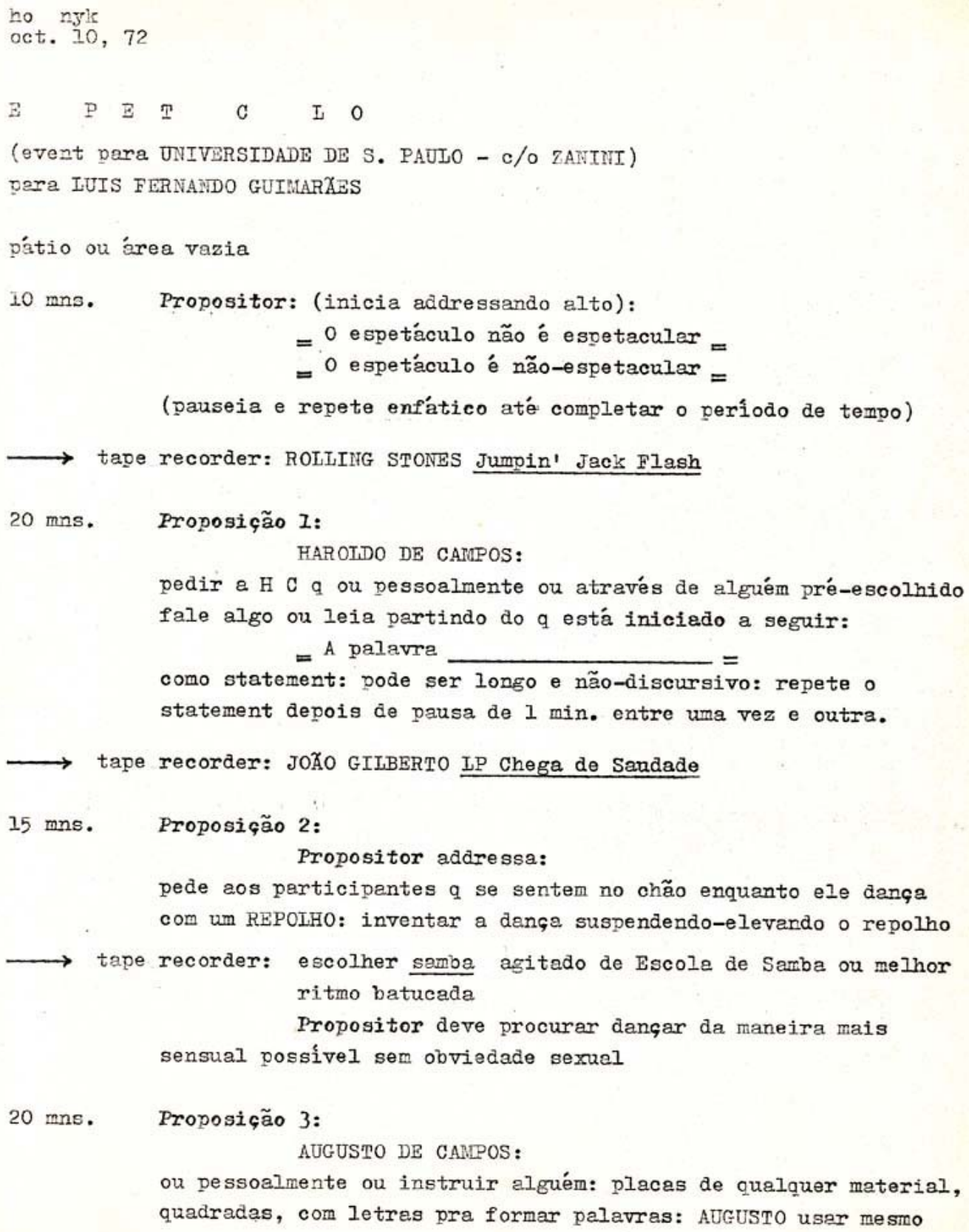

Figura 23 Figura 22 Instruções para Evento "E PET C LO" na Universidade de São Paulo. Catalogue Raisoneé n. doc. 0205.72 (Folha 1) 


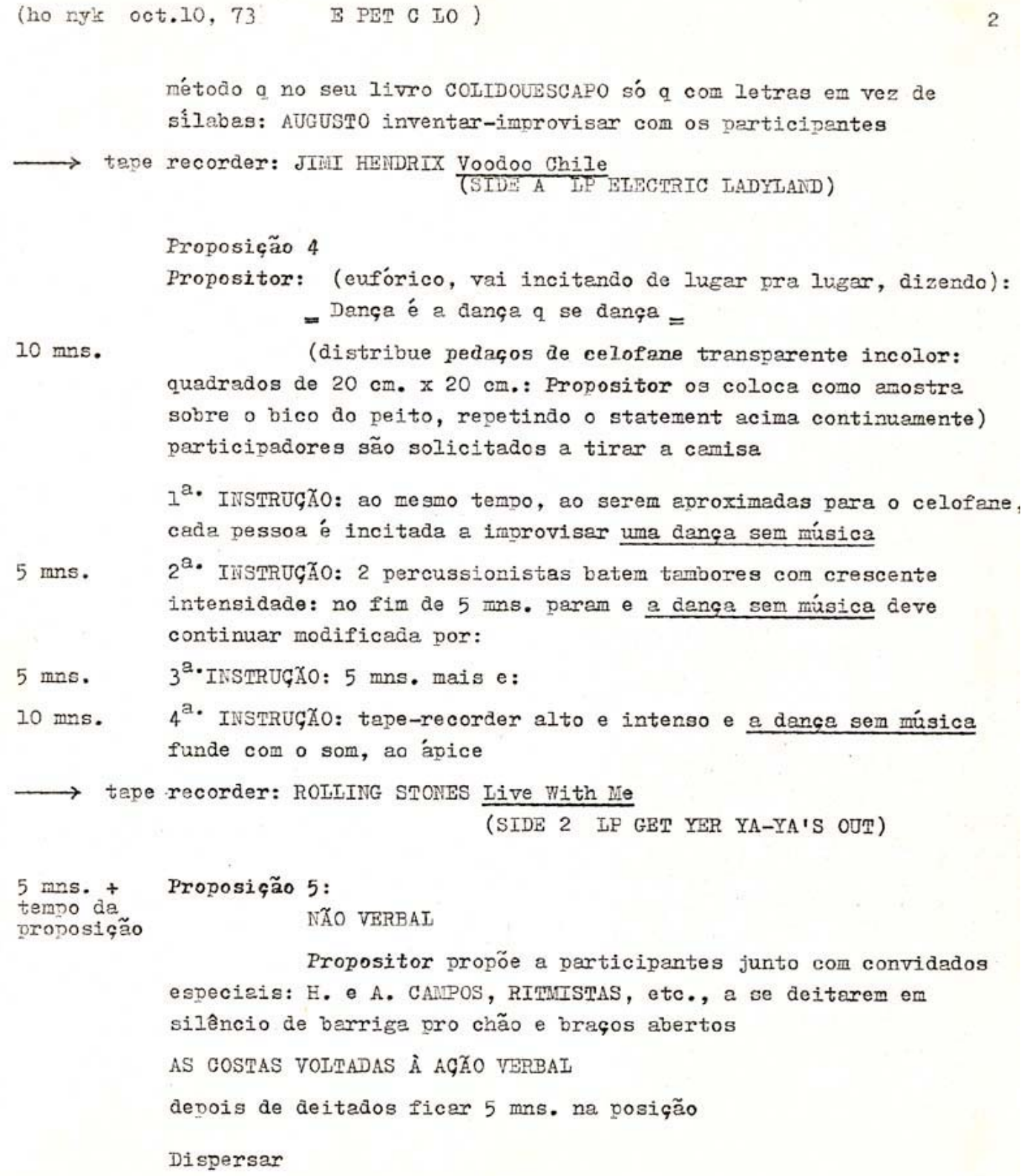

Figura 24 Instruções para Evento "E PET C LO" na Universidade de São Paulo. Catalogue Raisoneé n. doc. 0205.72 (Folha 2)

'E PET C LO' foi oferecida como homenagem a Walter Zanini, crítico e criador do curso de Artes Plásticas da USP. O evento deveria ocorrer na Universidade de São Paulo e teria como propositor seu amigo e ator Luiz Fernando Guimarães (Lfer), além da participação especial de Haroldo e Augusto de Campos. Previsto para acontecer em 1972, o evento não se realizou, apesar do consentimento de Walter Zanini e dos trâmites para sua realização na época como registrado em correspondências. O evento 
somente foi retomado e aprovado quase 40 anos depois, quando em 2009, a Escola de Comunicações e Artes da USP aprovou uma oficina sobre Hélio Oiticica, destinada ao Departamento de Artes Cênicas, ministrada por Lfer. Aberta a inscrições para os alunos também das Artes Visuais, Música e da Escola de Artes Dramática250, a oficina enfim levou à cabo os projetos da Parafernália Hélio Oiticica, que continham além de E PET C LO, No Reason to get excited, que Hélio desenvolveu na época para ser executado por Lfer em qualquer contexto: "prisão, sanatório, rua, universidade, god knows where", como comenta Hélio: "são encontros do circunstancial, e planejado ou improvisado são iguais nesses encontros: como se condições e situações se construíssem no ato em que são postas em práticas: práticas do circunstancial" 251.

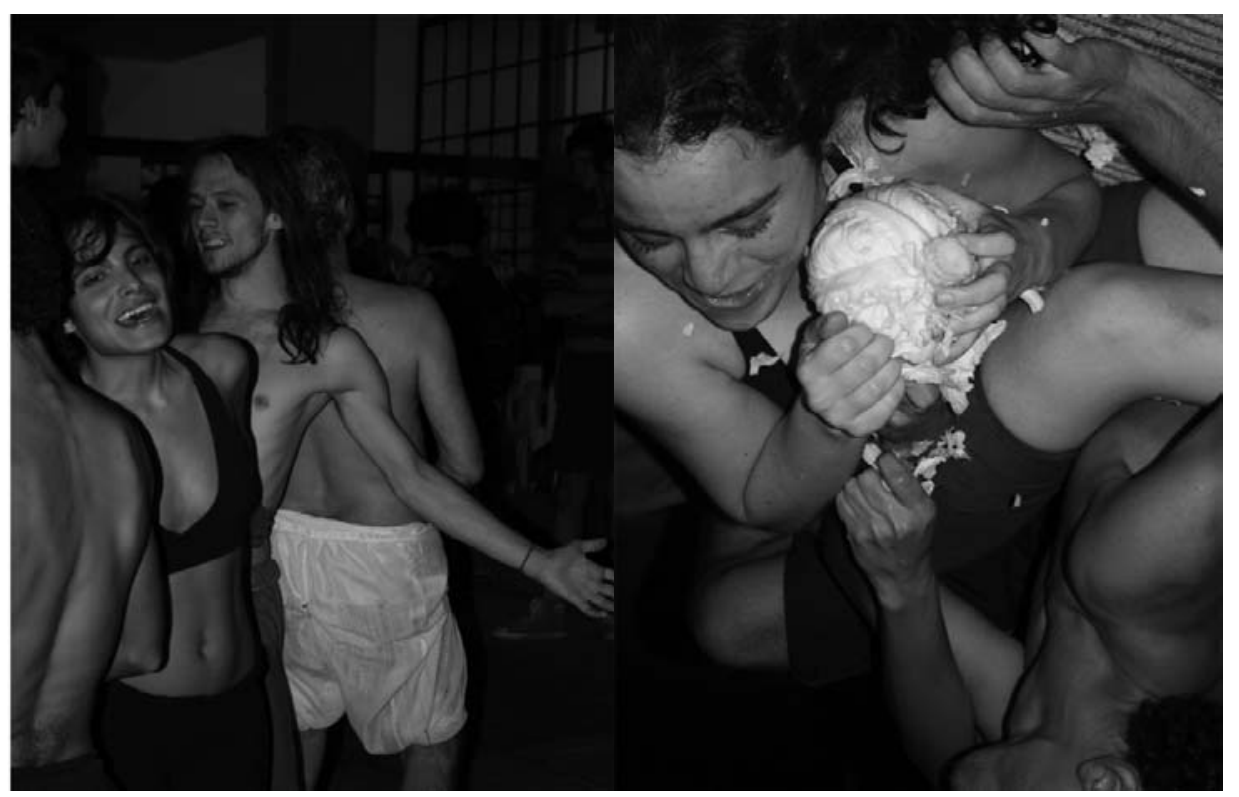

Figura 25 Event E PET C LO de HO desenvolvido na ECA-USP, 2009.

Neste período Hélio preparava um livro, que chamou de 'livro-projeto', "livromapa', subterrâneo ${ }^{252}$, que consistia numa série de textos que pretendia publicar, formado por 'textos-montagem": "não são discursivamente teóricos, mas como que justaposições de quotations minhas e de outros". Seu 'livro-projeto' foi pensado como um álbum de disco, que conteria quatro plantas baixas dos projetos que estava fazendo

250 Prado, Gilberto. Breve Relato da Pós Graduação em Artes Visuais da ECA-USP. ARS (São Paulo) [online]. 2009, vol. 7, n. 13, pp. 88-101. ISSN 1678-5320. http://dx.doi.org/10.1590/s1678532020090000100006 .

251 Oiticica, Hélio. Carta para Luis Fernando Guimarães. Nova Iorque, 30 de setembro de 1972. Catalogue Raisonné n. doc. 1294.72

252 Oiticica, Hélio. Carta para Ivan Cardoso. Nova Iorque, 24 de agosto de 1971. Catalogue Raisonné, n. doc. 0912.71. 
na época, textos relativos aos projetos e plantas, fotos das maquetes dos projetos, além de fotos dos projetos, fotos do repertório, desenhos de suas maquetes, fotos-imagens alusivas a prováveis proposições-performances. Seu "repertório" contava com citações de Haroldo e Augusto de Campos, Guy Debord (Society of the Spectacle), Pound \& Fenellosa, etc. Hélio cita a tese 30 de Guy Debord, com o objetivo de ressaltar aquilo que considera mais fundamental entre as coisas que Debord diz:

A alienação do espectador em favor do objeto contemplado (o que resulta de sua própria atividade inconsciente) se expressa assim: quanto mais ele contempla, menos vive; quanto mais aceita reconhecerse nas imagens dominantes da necessidade, menos compreende sua própria existência e seu próprio desejo. Em relação ao homem que age, a exterioridade do espetáculo aparece no fato de seus próprios gestos já não serem seus, mas de um outro que os representa por ele. É por isso que o espectador não se sente em casa em nenhum lugar, pois o espetáculo está em toda parte”253.

A crítica à sociedade do espetáculo de Guy Debord veio elucidar uma série de questões que Hélio vivenciava: sobre sua obra, o conceito de obra e a tomada de posição do artista como propositor de práticas e 'construtor de situações'. Hélio beneficiava-se de uma visão marginal, vislumbrou o problema do 'espetáculo' na sociedade atual, enxergando este movimento perpétuo da produção do 'espetáculo' que coloca o homem cada dia mais distante da vida cotidiana: "o homem separado de seu produto produz, cada vez mais e com mais força, todos os detalhes de seu mundo. Assim, vê-se cada vez mais separado de seu mundo. Quanto mais sua vida se torna seu produto, tanto mais ele se separa da vida" 254 . A atividade inconsciente que o homem produz é o que resulta na alienação do espectador, "o espetáculo na sociedade

253 "the alienation of the spectator to the profit of the contemplated object (which is the result of his own unconscious activity) is expressed in the following way: the more he contemplates the less he lives; the more he accepts recognizing himself in the dominant images of need, the less he understands his own existence and his own desires. The externality of the spectacle in relation to the active man appears in that his own gestures are no longer his but those of another who represents them to him. This is why the spectator does not feel at home anywhere, because the spectacle is everywhere". Carta de Hélio Oiticica a Mario Pedrosa. Babylon, New York, 30 de Julho de 1971. In Catalogue Raisonné no doc. 0920.71 p.1-3.

254 Debord, Guy-Ernest. A Sociedade do Espetáculo, tese 33, p. 25. 
corresponde a uma fabricação concreta da alienação"255. Essas discussões em torno do artista marginal, do objeto artístico e do problema do 'participador' no 'mundo espetáculo', estão bastante presentes já em cartas trocadas com Lygia Clark em 1968. Em uma dessas cartas, Hélio explica esta sua posição marginal citando Hebert Marcuse:

para Marcuse, os artistas, filósofos, etc., são os que têm consciência disso ou 'agem marginalmente' pois não possuem "classe" social definida, mas são o que ele chama de "desclassificados", é nisso que se identificam com o marginal, isto é com aqueles que exercem atividades marginais ao trabalho produtivo alienante: o trabalho do artista é produtivo, mas no sentido real da produção-produção, criativo, e não alienante como os que existem em geral numa sociedade capitalista. Quando digo 'posição à margem' quero algo semelhante a esse conceito marcuseano: não se trata da gratuidade marginal ou de querer ser marginal à força, mas sim colocar no sentido social bem claro a posição do criador, que não só denuncia uma sociedade alienada de si mesma mas propõe, por uma posição permanentemente crítica, a desmistificação dos mitos da classe dominante, das forças da repressão, que além da repressão natural, individual inerente na psique de cada um, são a 'mais-repressão' e tudo o que envolve a necessidade da manutenção dessa mais-repressão ${ }^{256}$.

Essas discussões com Lygia Clark estendiam-se à função do objeto como mediador da relação do artista e do espectador (participante), onde o que era "euobjeto-você”, deveria ser substituído por “eu-você”. Nessa medida, segundo Hélio, o mediador a ser abolido não era exatamente o objeto mas o “espetáculo” e a “mercadoria como espetáculo”. Segundo Debord, “o que liga os espectadores é apenas

255 idem, tese 32, p. 24.

256 Hélio ainda complementa citando uma outra referência: Frantz Fanon, "um negro marroquino, revolucionário, que segundo Rogério Duarte é tão violento que Marcuse se torna um "metafísico": "há vários livros dele, sendo que o mais famoso é "Les Damnés de la Terre" com prefácio de Sartre", (Fanon, Frantz. Les Damnés de la Terre. Paris: François Maspero, 1961-68). "Fanon vivencia como um revolucionário, pela experiência mesmo: ele participou da guerra da Argélia e foi assassinado posteriormente". in Oiticica, Hélio. Carta para Lygia Clark. Rio de Janeiro, 8 de novembro de 1968. Catalogue Raisonné n. doc. 1036.68. 
uma ligação irreversível com o próprio centro que os mantém isolados. O espetáculo reúne o separado, mas o reúne como separado”257.

Refletir sobre o Éden a partir do arcabouço teórico de Debord parece ter sido também algo inevitável. Em carta a Mário Pedrosa, Hélio expõe que ao entrar em contato com uma versão em inglês do texto de Guy Debord, Society of the Spectacle algumas questões fundamentais sobre o Éden emergiram: uma necessidade de 'esclarecer' mais do que 'buscar significados', nasceu da constatação da existência de "um mito estúpido e alienante em volta do que eu possa representar, no Brasil", comenta Hélio, diante de sua insatisfação diante dos convites que recebera no Brasil para expor seus trabalhos - manifestações ambientais - em galerias. Buscando desfazer tal mito, Hélio pede a Mario Pedrosa que lhe envie um texto sobre sua obra Éden, pois gostaria de comparar seus escritos a suas últimas reflexões. Segundo Hélio, Éden é um pre-modelo de proposições para o lazer não repressivo, ao contrário do que muita gente pensa, jamais foi uma representação naturalista do que quer que seja ${ }^{258}$. Ao responder a Hélio, Mário Pedrosa enfatiza este caráter

Éden é um pré-modelo onde tudo é presente, embora não ao alcance assim imediato dos sentidos, e nem mesmo tão perto da imaginação. Com os nossos índios era assim mas aquele paraíso deles não foi modelo nunca pra nada, nem mesmo pré-modelo deles. (...)Eles não sabiam de nada mas gozavam de tudo, isto é, com sofrimento também, é claro, morriam, etc. A tua procura do Éden é a via única do artista pois a tarefa do artista hoje - para que se possa compreender a sua existência , ou justificá-la, - é conceber o prazer total, em suma, a felicidade 259 .

Detendo-se no problema do tempo livre na 'sociedade do espetáculo', Debord divisa um tempo irreversível implacável (em oposição ao tempo cíclico da natureza) e um espetáculo alienante do qual nada escapa e que na sociedade moderna imediatamente a tudo transforma em lucro, o tempo (agora irreversível) também é

257 Debord, Guy. A Sociedade do Espetáculo, Rio de Janeiro: Contraponto, 1997. tese 29.

258 Oiticica, Hélio. Carta de Hélio Oiticica a Mario Pedrosa. Nova Iorque, 30 de Julho de 1971. In Catalogue Raisonné no doc. 0920.71 p.1-3.

259 Pedrosa, Mário. Carta de Mário Pedrosa à Hélio Oiticica. Santiago, 2 de outubro de 1971. Catalogue Raisonné n. doc. 1179.71. 
usurpado do indivíduo na sociedade do espetáculo - sociedade pautada na aparência, na imagem-objeto, no espetáculo como meio e fim de si mesmo, que se apropria do que resta do tempo que a produção da economia já não tenha tirado do indivíduo, integrando-o ao processo produção-consumo e dele também auferindo lucros. Éden era mais um 'deslugar', como define Haroldo de Campos, que Hélio criara para o exercício lúdico e prazeroso do corpo, servindo para um lazer criativo, o Crelazer, uma procura pelo prazer, usufruído no 'tempo livre'.

Vivendo em Nova Iorque e em total efervescência criativa e reflexiva, ao contrário dos críticos que acreditavam tratar-se de um período de retração e de improdutividade, Hélio em sobressalto viu seu trabalho no Brasil, sua produção tão recente, ser cooptada pelo processo de reificação: "sinto que tudo o que procurei fazer ficou numa zona perigosa de dissolução: entre o contexto brasileiro e o internacional, sem estar firmemente plantado nem em um, nem no outro; se bem que aqui, haja mais possibilidade das ideias serem abordadas com maior ênfase; no Brasil, onde militei mais, ficaram jogadas no nada"260. Em carta a Haroldo de Campos, Hélio explica: "queriam propor-me exposições de bólides e penetráveis, como se fossem peças descartáveis dos contextos ambientais (manifestações ambientais) para os quais foram criados"261. O Parangolé, por exemplo, transformou-se em "arte parangolé", o "ambiental", em "arte ambiental", e o que considerou ainda mais grave, o caso de "tropicália", que absorvida, transformou-se em "tropicalismo":

Haroldo de Campos numa previsão distinguia e avisava que não deveria ser "tropicalismo", foi absorvida, malconduzida e tal: 'tropicália' é ainda 'tropicália', conceito que coloca a ideia de manifestação "sui generis” da busca do 'experimental' no Brasil, sob um ponto de vista crítico-conflitual, que está na origem de sua criação262.

Procurando "desmitificar", "tirar o engano" sobre o caráter experimental de suas obras e a inadequação destes trabalhos em galerias, Hélio escreve de Nova Iorque

\footnotetext{
260 Oiticica, Hélio. Carta para Haroldo de Campo. Nova Iorque, 19 de outubro de 1971. Catalogue Raisonné, doc. n. 085.71.

261 . idem.

262 Oiticica, H. Texto sobre a participação do espectador na obra. Nova Iorque, 10 de junho de 1971. In Catalogue Raisonné $\mathrm{n}^{\circ}$ doc. 0278.71.
} 
um artigo para ser publicado na coluna de Torquato Neto em Geleia Geral, sob o título: Oiticica: Exposição? Eu não!. Neste artigo, Hélio é enfático e elenca uma série de questões que pretende esclarecer: "Não estou aqui para fazer retrospectivas, como um artista acabado; estou no início de algo maior; quem não entender que se dane"; quanto às exposições já realizadas ${ }^{263}$, diz: foram sempre experiências ambientais, sensoriais, de participação pública, nunca houve uma preocupação em realizar "uma exposição a mais"; e sobre os planos para a Praça da República em São Paulo, explica tratar-se de uma experiência de rua:

não são planos para ficarem no papel (não sou "artista conceitual" e nunca fui). Minhas experiências têm mais haver hoje com circo do que com promotores de arte: não estou a fim de alegrar burguesias interessadas em arte" (...)"não faço vestimenta de vanguarda" como muitos para esconder ideias conservadoras 264 .

Hélio via que os processos artísticos de natureza experimental, "comprometidos de raiz com o 'espectador"', tinham sido absorvidos no contexto "artístico espetacular"265. Sobre essa questão, Debord é contundente, pois, sob a égide do espetáculo, toda e qualquer representação que se queira independente, “marginal”, o espetáculo reconstitui, ou seja, é efêmera a vida fora do mainstream. Theodor Adorno, em racionalidade técnica em Adorno 266 . A racionalidade é a da própria dominação, é o caráter repressivo da sociedade que se auto aliena, que torna todos os sujeitos iguais ao sujeitá-los, autoritariamente, aos idênticos padrões e clichês, em rádios, cinema, televisão ou qualquer outra mídia. Sendo efêmera e clandestina qualquer tentativa ou sistema de réplica. É o caso de estações de rádio clandestinas que se opõem à mesmice

\footnotetext{
263 exposiç̃os realizadas até este momento: uma no Rio, em 66 (G-4); experiências no MAM e na Rua (Apocalipopótese, em 68, Tropicália, em abril de 67); internacionais: uma retrospectiva na Whitechapel em Londres (69, que foi uma experiência ambiental (sensorial) limite; e em 70, praticamente 1/3 da exposição Information, no Museu de Arte Moderna do New York, dedicado a mim (ninhos).

264 Oiticica, Hélio. Oiticica: Exposição? Eu não! Jornal Última Hora, Geleia Geral, Rio de Janeiro, 1 de setembro de 1971. Catalogue Raisonné n. doc. 0883.71.

265 Oiticica, H. Texto sobre a participação do espectador na obra. Nova Iorque, 10 de junho de 1971. In Catalogue Raisonné $\mathrm{n}^{\circ}$ doc. 0278.71.

266 Adorno, T. Indústria cultural e sociedade. São Paulo, Ed. Paz e Terra, 2002 (3 $3^{\mathrm{a}}$ ed) p. 30.
} 
das centenas existentes, mas quando “representativas” são prontamente absorvidas; “uma vez registrado em sua diferença pela indústria cultural, já faz parte desta”267.

A tese 30 de A Sociedade do Espetáculo, citada acima, é diversas vezes retomada por Hélio em seus escritos, como em “texto reflexão”, escrito em 10 de junho de 1971, no qual discorre sobre o problema da atividade criativa no "mundo do espetáculo”, onde o espectador é impelido a transitar de sua posição passiva para a de propositor $^{268}$, e em Anotações para serem traduzidas para o inglês para uma próxima publicação ${ }^{269}$, de $1^{\circ}$ de setembro de 1971 . Neste texto Oiticica inicia com uma citação de Décio Pignatari e termina com a tese 30 de Debord. As frases se complementam em seus conteúdos. Pignatari fala da antiarte como linguagem vinculada à comunicação, sobretudo, a comunicação com a massa, em oposição ao sistema vigente de administração da cultura, que impõe seus interesses (consumistas e mercadológicos) em detrimento da criação artística:

este ser anti-arte está intimamente vinculado ao estabelecimento de uma linguagem, de um projeto geral - ou de um roteiro, para utilizar um termo oswaldiano. Envolve, em última instância, um problema de comunicação, e de comunicação com a massa por via imediata e direta; em oposição, portanto, ao sistema vigente de administração da cultura (complexo editorial, ensino, museus, exposições, concertos, etc.), que é de natureza consumista, impondo os ditames de seus interesses às fontes de criação artística. $O$ quixotismo, em toda vanguarda genuína, é um risco - se o for necessário... e alimentício 270 .

Debord acusa as consequências desse processo, ou seja, quando o espetáculo encontra-se em toda a parte, a consequência é a alienação do espectador, a perda de controle sobre sua própria vida e seus próprios desejos. Por sua vez, Hélio aponta a subsistência intelectual, poética, criadora mesmo em face aos aspectos do

267 Ibid., p. 23.

268 Oiticica, Hélio. Texto sobre a participação do espectador na obra. Nova Iorque, 10 de junho de 1971. In Catalogue Raisonné ${ }^{\circ}$ doc. 0278.71.

269 Oiticica, H. Anotações para serem traduzidas para o inglês. Nova Iorque, $1^{\circ}$ de setembro de 1971. In: Catalogue Raisonné, $\mathrm{n}^{\circ}$ doc. 0271.71 p. 1-4.

270 Oiticica, H. Anotações para serem traduzidas para o inglês. Nova Iorque, 1 de setembro de 1971. In: Catalogue Raisonné, $\mathrm{n}^{\circ}$ doc. 0271.71 p. 1-4. 
consumismo ou do espetáculo, colocando-se totalmente contra esse processo 'diluidor': desligo-me totalmente de qualquer produto de diluição ou de tentativa de levar o conceito para uma 'saturação consumitiva', além de acreditar que fora do contexto brasileiro dá-se melhor o julgamento da força que esse conceito possa possuir e procurar o fio que o determina como intimamente ligado ao problema crítico do deslocamento do conceito do espectador para o de espectador-participador: "logo, para uma posição conflitual, que segundo me parece é no momento ainda a mais eficaz: não aceitar a compulsividade da diluição como estado definitivo"271. Posteriormente, Hélio define seu 'estado de espírito' como o de 'subsistência', que explicaria o problema de criação artística no 'mundo do espetáculo' que transforma a arte rapidamente em commodities $^{272}$.

271 Oiticica, H. Texto sobre a participação do espectador na obra. Nova Iorque, 10 de junho de 1971. In Catalogue Raisonné n ${ }^{\circ}$ doc. 0278.71.

272 Oiticica, H. Anotações para serem traduzidas para o inglês. New York, 1 de setembro de 1971. In: Catalogue Raisonné $\mathrm{n}^{\circ}$ doc. 0271.71 



\subsection{O Delirium (De)Ambulatorium}

Hélio definiu Delirium Ambulatorium como "uma necessidade de alimentar renovações" (..) "necessário para esvaziar a cabeça de tudo o que é cerebral e fazer com que fique livre para então emergir o NOVO"273. Não é possível precisar desde quando Hélio começou a utilizar tal expressão para designar suas caminhadas pelas ruas da cidade ou como parte de seu processo criativo. No ano de 1970, mais precisamente em 2 de agosto daquele ano, Hélio utilizou a expressão delírio ambulatório em carta a Lygia Clark, para explicar o estado de espírito que lhe tomou, ao receber a notícia de que tinha tido seu pedido de bolsa aprovado pela Fundação Guggenheim em Nova Iorque, e que tal notícia havia lhe feito andar incansavelmente pela cidade: "sinto-me livre de repente e isso me agrada bastante" (...) "parece que estou vivo outra vez" (...) "fiquei num tal delírio ambulatório que não parei de andar dia e noite pela cidade"274. Mais tarde, já de volta ao Rio de Janeiro, Hélio chegou a afirmar que suas experiências de andar pela cidade sempre estiveram presentes em sua vida, tanto que foi desses delírios que surgiram, ainda nos anos 1960, as propostas de apropriações de obras de rua, e nos anos 1970, o que denominou como uma espécie de “aventura-expedição” ou projeto-delirium ambulatorium-objet trouvé. Destas expedições pela cidade, explica Hélio, surgiu o projeto Pres. Vargas-Kioto/Gaudi, além do Programa in Progress Caju 275.

Entretanto, foi por ocasião do evento Mitos Vadios, organizado pelo artista Ivald Granato em 1978, que Hélio utilizou a expressão Delirium Amulatórium pela primeira vez para designar uma expressão artística, ou seja, uma prática do andar como prática estética.

273 Oiticica, Hélio. Carta a Daniel Más. Rio de Janeiro, 8 de dezembro de 1978. in Catalogue Raisonné n. doc. 0092.78.

274 Oiticica, Hélio. Carta para Lygia Clark. Nova Iorque, 2 de agosto de 1970. Catalogue Raisonné n. doc. 0749.70 .

275 Oiticica, Hélio. Carta a Daniel Más. Rio de Janeiro, 8 de dezembro de 1978. in Catalogue Raisonné n. doc. 0092.78 . 
Mitos Vadios foi um evento para contestar a $1^{\circ}$ Bienal Latino-Americana de São Paulo e seu tema "Mitos e Magias", que havia deixado de fora países de importância cultural como a Venezuela e nomes representativos da arte como Torres Garcia, Armando Reveron, Roberto Matta (...), os muralistas mexicanos, além dos brasileiros, Waltércio Caldas, Artur Barrio, Tunga, Cildo Meireles, Hélio Oiticica, Cláudio Tozzi, Antonio Manuel, Lygia Pape, entre outros.

Ivald Granato idealizou Mitos Vadios como um acontecimento totalmente experimental que deveria ter a participação de artistas e do público, uma manifestação que tinha como ponto chave a total liberdade dos artistas presentes de criarem aquilo que bem quisessem, “sem se preocuparem com rótulos, condições ou especificidades”. Para mobilizar os artistas e o público a participarem de Mitos Vadios, Ivald Granato, meses antes, distribuiu cartazes com os dizeres “mitos vadios” pela cidade de São Paulo, contou com o apoio da imprensa na época que incluiu notas em jornais para anunciarem o evento. Pouco a pouco os artistas foram aderindo à manifestação 276 .

Segundo Ivald Granato, ao comunicar sobre Mitos Vadios a Hélio e a Lygia Pape, logo o evento que tinha cerca de 18 artistas tomou uma nova proporção, com a adesão de 60 artistas de diversas áreas. A contestação à $1^{\circ}$ Bienal Latino Americana transformou-se apenas em mais um pretexto, uma vez que a dimensão do evento ampliou-se, alargando, consequentemente, os repertórios e as possibilidades de

276 Artistas presentes em Mitos Vadios: Gabriel Borba, Barrio, Mauricio Fridman, Claudio Tozzi, Marta Minujin, Ivald Granato, Lfer, Antonio Dias, Sergio Regis, Ubirajara Ribeiro, Ruy Pereira, Inarra, Gemilson, Olney Kruse, Regina Vater, Jailton Fonseca, Gretta, Portillos, Ibanez, Lygia Pape, Rubens. in Oiticica, Hélio. "Mitos Vadios". Jornal Diário de São Paulo, São Paulo, 5 de novembro de 1978. in Catalogue Raisonné n. doc. 0943.78. Posteriormente aderiram à Mitos Vadios com suas respectivas manifestações: Luciano Figueiredo e Oscar Ramos (poetas gráficos LONDRES-VADIOS), Maurício Cirne (performance Dancin’Days Julia-Rose), Norma Bengell (filme e possível presença ao vivo), Macalé (performance ao vivo), Maria Gladys (musa Vadia do Udigrudi), Neville de Almeida (homenagem à Dama Vadia do Lotação, com a presença do cineasta), Júlio Bressane (convidado especial de Hélio Oiticica para ser homenageado), Andreas Valentim (performance com Dulchi improvisada), Wally Sailormoon (Vadio Real Grandeza), Nanci Brigacão (cientista política) e Esther Emílio Carlos (crítica de arte que adere aos mitos contra a Bienal latino-americana e fará declarações a respeito)". in Motta, Nelson. Mitos Vadios no "Fantástico". Jornal O Globo, Rio de Janeiro, 12 de novembro de 1978. in Catalogue Raisonné n. doc. 1018.78. O cineasta Júlio Bressane, participou junto com Maurício Cirne e Cláudio Tozzi, com um projeto que consistia em 20 cadeiras escolares amarradas com cordas e voltadas para um cavalete de pintura com uma tela pintada de preto, o gravurista Ubirajara Ribeiro aderiu a "Mitos Vadios” "pela possibilidade de chegar ao público não apenas através de suas obras, mas também como produtor: "È necessário ao artista encontrar formas de maior aproximação com o público. O clima de festa, de reunião social que transpira das galerias atemoriza. Da mesma forma o excessivo formalismo dos museus que, com raras exceções, permanecem geralmente vazios”. in "60 artistas dão hoje sua versão dos Mitos, na rua". Artigo de autoria de Celso Marinho. Jornal Folha de São Paulo, São Paulo, 12 de novembro de 1978. Catalogue Raisonné n. doc. 1019.78 
manifestações. Mitos Vadios transformou-se num "exercício da liberdade", como comentou Lygia Pape em referência à frase de Mário Pedrosa:

É Liberdade. Cada um, com seus repertórios, faz a leitura que quiser. É um protesto de todos. Não existe forma ideológica. (...) Seria fascista querer que todos vejam de uma maneira. (...). Não propomos uma teoria política e sim liberdade total. Qualquer pessoa, seja metalúrgico, operário, pode captar essa experiência de liberdade... ${ }^{277}$

Hélio apoiou a iniciativa e elaborou sua participação a partir da DUPLA DELIRIUM AMBULATORIUM, formada por ele e seu amigo Lfer. Sua proposta consistia em "caminhar sem linearidade", propondo que enquanto caminhava inventava "coisas para fazer", num processo que chamou de "poetizar o urbano". As atividades previstas para acontecer durante o evento foram descritas em "TextoRelease”, de 24 de outubro de 1978:

Levar do Rio capa-faixa de murim plastificado com cola vinílica para ser enrolada em corpos diversos: procurar a "pele preta" ideal para o toque da faixa-murim. Levar em sacos ou talvez solucionado de outro modo: talvez nos containers de vinil de fotografia apanhados em São Cristóvão 278 .

No dia do evento, 12 de novembro de 1978, num grande estacionamento da Rua Augusta, $\mathrm{n}^{\circ}$ 2918, Ivald Granato que tinha sua chegada programada de helicóptero, deparou-se com uma multidão lá embaixo e precisou ir até o local de carro. Chegou trajado de Ciccilo Matarazzo, numa performance denominada My name is not Ciccilo Matarazzo, enquanto Hélio Oiticica o esperava de sunga de praia, sapato de black comprado na Washington Square, óculos de aviador e cabeleira de Escola de Samba verde, ao som de Rolling Stones (grupo eleito na ocasião como Monumento ao Vadio), dançando "Miss You". Araci Peipe, nome de guerra de Lygia Pape, recebeu Granato como Embaixatriz dos Stones e rolou no chão numa área de frestas, num

277 Lygia Pape em "Vadiagem". Artigo e entrevista de Fátima Turci. Jornal Última Hora, Rio de Janeiro, 11 de dezembro de 1978. in Catalogue Raisonné n. doc. 0946.78.

278 Oiticica, Hélio. Texto-Release para minha participação em Mitos Vadios de Ivald Granato. Rio de Janeiro, 24 de outubro de 1978. in Catalogue Raisonné n. doc. 0066.78. 
cascalho redondo em homenagem aos Stones (a rolling stones for the Rolling Stones) $)^{279}$.

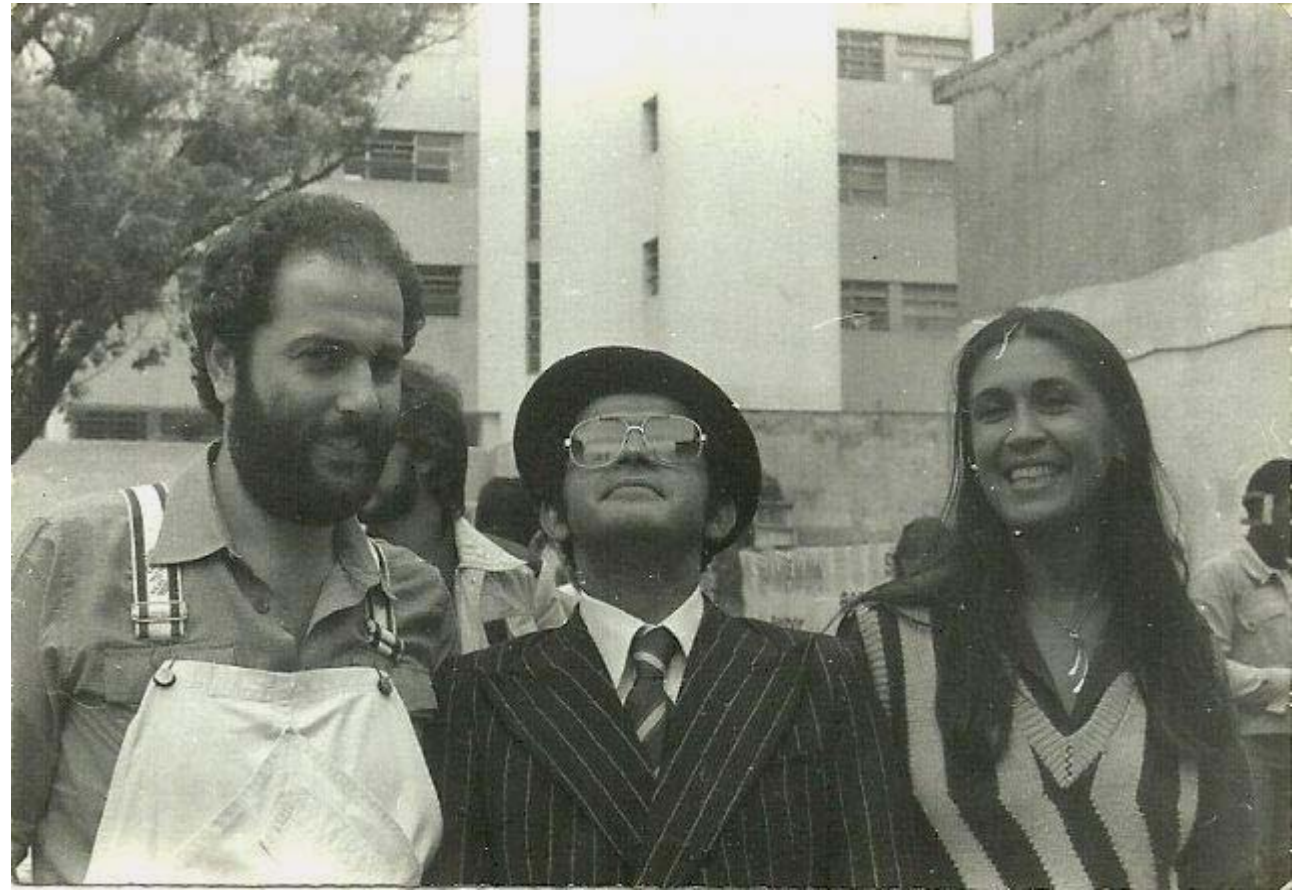

Figura 26 Ivald Granato entre Hector Babenco e Raquel Arnauld em Mitos Vadios. Acervo Ivald Granato

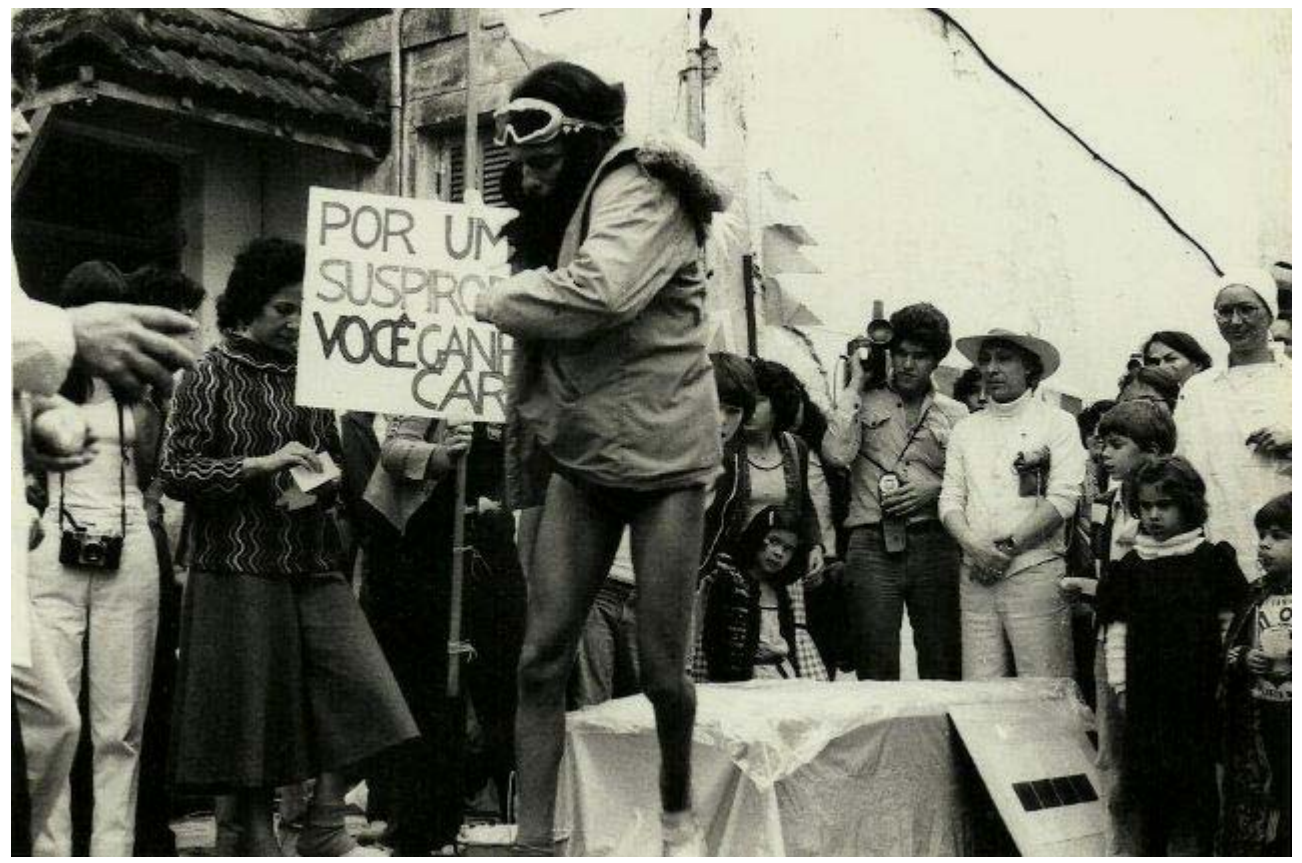

Figura 27 Hélio Oiticica em Mitos Vadios, 1978. Acervo Ivald Granato.

279 Motta, Nelson. Mitos e Vadios no Fantástico. Jornal O Globo, Rio de Janeiro, 12 de novembro de 1978. in Catalogue Raisonné n. doc. 1018.78. 


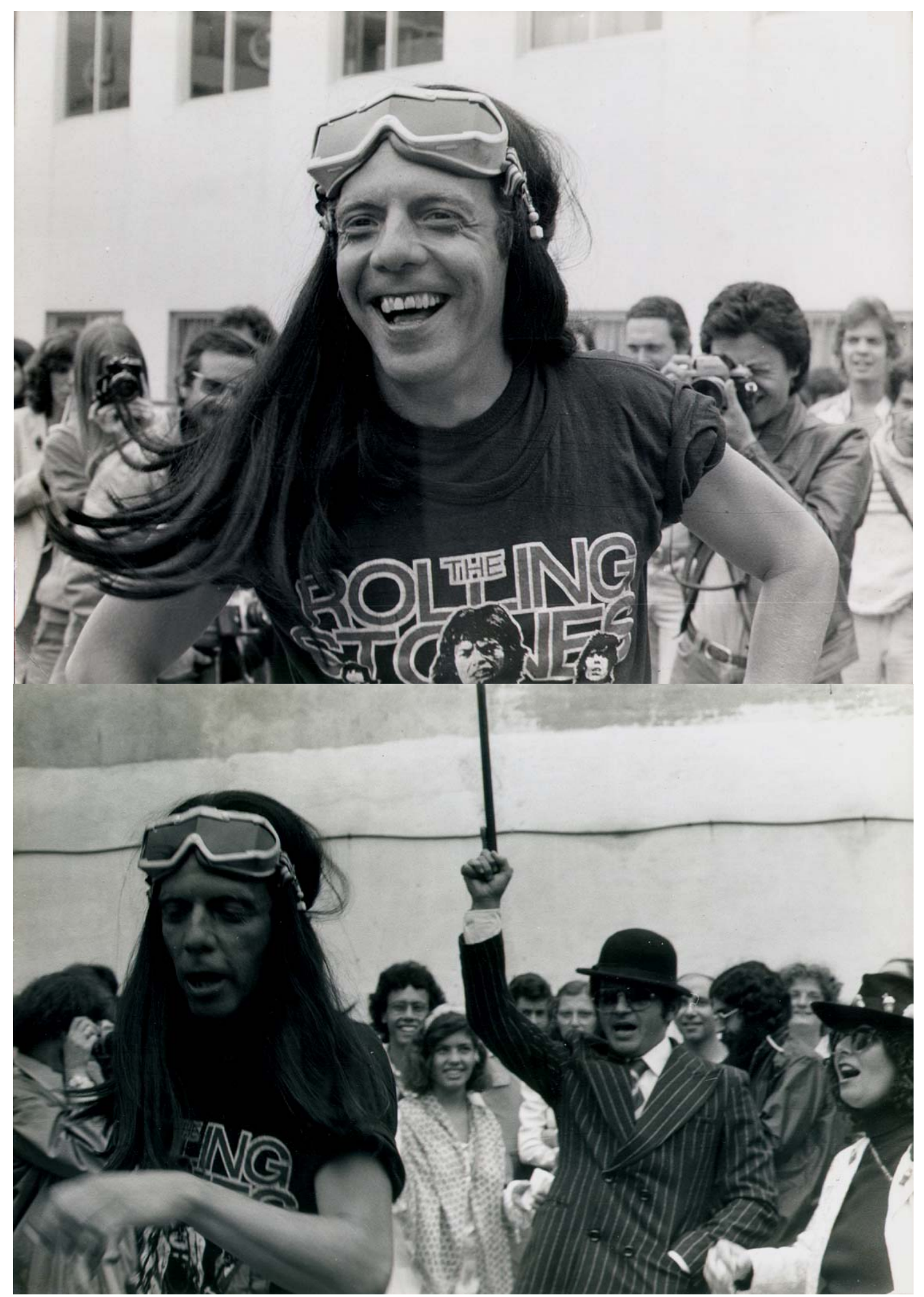

Figura 28 Hélio Oiticica em Mitos Vadios. in Catalogue Raisonné n. doc. 2244.78 


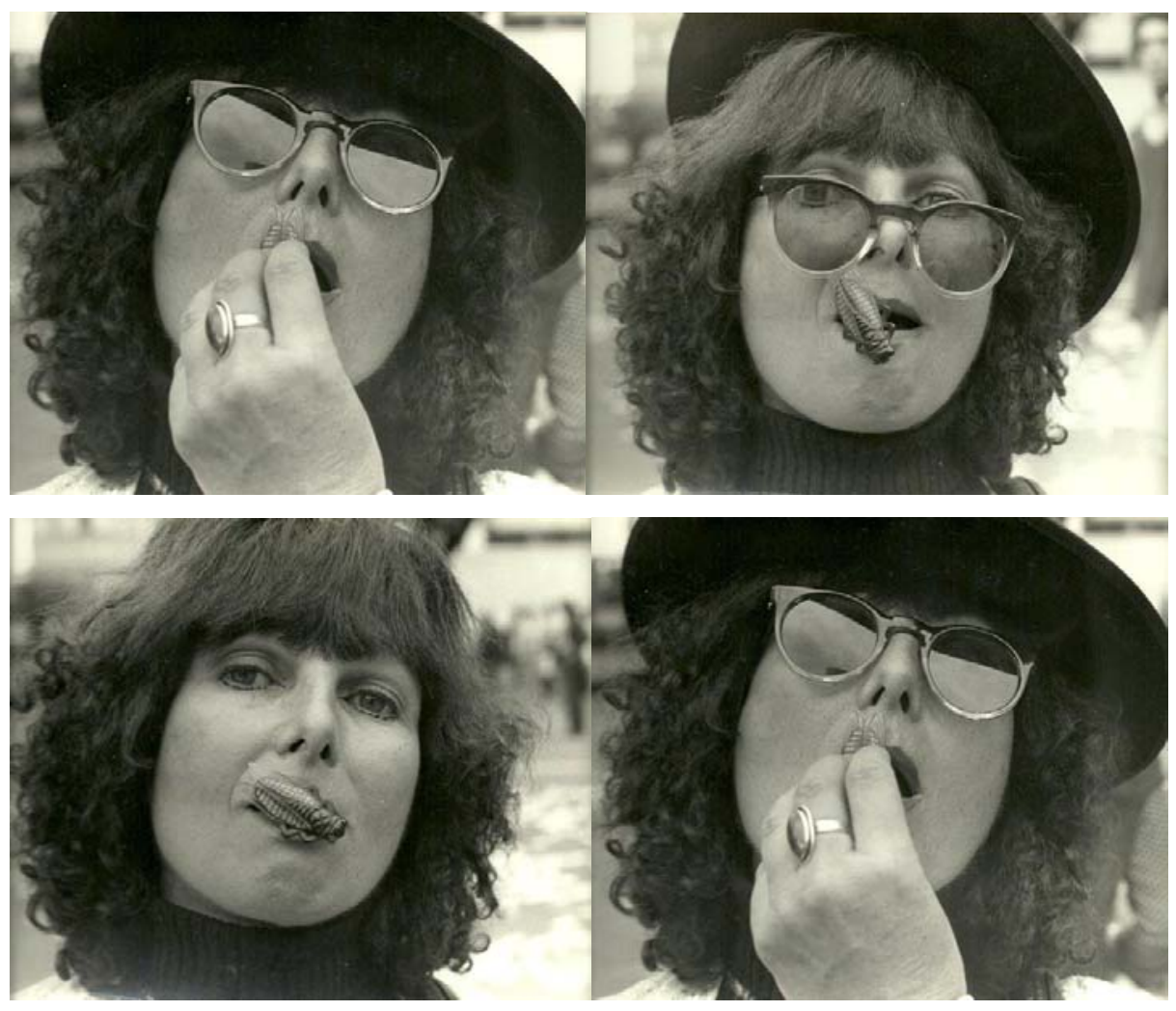

Figura 29 Participação de Lygia Pape em Mitos Vadios. in Acervo Ivald Granato.

Alguns meses antes de Mitos Vadios, Hélio e Lfer encontraram-se em São Paulo, assistiram ao festival de Montreux-São Paulo de Jazz, com apresentação de Taj Mahal Martine's, John Mclaughlin e realizaram "andanças-deliriums night afora", como comenta em carta a Olympio: "andei São Paulo inteira! e comprei mapa e andei de Metrô que é incrível! Não é possível conhecer a cidade andando de táxi ${ }^{280}$. A experiência da deambulação em São Paulo tomou um sentido de (re)conhecimento da cidade, uma necessidade de apropriação das ruas de Sampa, expressão que Hélio utiliza em referência à música de Caetano Veloso que havia se transformado numa espécie de hino dos paulistas 281.

Entretanto, se por um lado, São Paulo é "o avesso do avesso do avesso do avesso", por outro, seria ilusão referir-se ao Rio de Janeiro como "a princesinha dos trópicos"282. A denominação mais condizente com as transformações abruptas que a cidade do Rio de Janeiro havia sofrido nas últimas décadas seria a de "cidade

280 Oiticica, Hélio. Carta a Olympio Vasconcelos. Rio de Janeiro, 30 de setembro de 1978. in Catalogue Raisonné n. doc. 1495.78.

281 idem.

282 Hélio citando conversa com Glauber Rocha. in Carta para Daniel Más. (texto para ser publicado na Revista Vogue). Rio de Janeiro, 8 de dezembro de 1978. in Catalogue Raisonné n. doc. 0092.78. 
selvagem", como comenta Hélio: "o Rio é brutal porque é uma cidade sem nostalgia e nada mais absurdo do que nostalgiar (sic) o Rio (Rio antigo etc.): o Rio não tem memória: é ahistórico"283. As transformações no sistema de comunicação urbanos, como a construção de viadutos e túneis, acabou com a ideia de subúrbio, o que era "subúrbio e cidade", virou tudo um "subúrbio-cidade284, exemplifica.

A experiência da deambulação no Rio de Janeiro levou Hélio não somente à aproximação desses processos urbanos ("estrutura em desestruturação estruturação permanente"285) como o dotou de um olhar diferenciado para com as transformações do tecido urbano e as relações sociais ali desenvolvidas. Em seu delirium ambulatorium está presente a importância do coletivo, da participação, bem como, da abordagem lúdica da cidade, como formas de (re)-estabelecer as relações entre o habitante e a cidade. Segundo Hélio, "o Rio é a cidade ideal que amálgama níveis/bairros/regiões totalmente diversas num campo urbano só: o Rio é o paraíso do delirium ambulatorium!", e é a partir do delirium ambulatorium que o campo urbano se transforma em um 'objeto relacional', "um labirinto topográfico"286.

Hélio debruça-se mais demoradamente nos conceitos em torno do Delirium Ambulatorium em Manifesto Caju, texto que escreve em referência ao Programa in Progress Caju. Entretanto, observa-se que no desenvolvimento de seu texto, julgando o termo "manifesto" inapropriado, uma vez que não se trata de um "programa prédefinido", ao contrário, encontra-se aberto a sugestões e à participação coletiva, Hélio o renomeia para Memorando Delirium Ambulatorium. Em Memorando Delirium Ambulatorio, de fato, mais do que focar na experiência particular da deambulação na região degradada do Caju (outrora lugar destinado ao lazer da família Imperial, agora aterro de lixo ${ }^{287}$ ), Hélio expande a definição de delirium ambulatorium, presente

283 Oiticica, Hélio. Para Daniel Más/Vogue (texto para ser publicado na Revista Vogue). Rio de Janeiro, 8 de dezembro de 1978. in Catalogue Raisonné n. doc. 0092.78.

284 Oiticica, Hélio. Para Daniel Más/Vogue (texto para ser publicado na Revista Vogue). Rio de Janeiro, 8 de dezembro de 1978. in Catalogue Raisonné n. doc. 0092.78.

285 Valadares, Nanci. Rio Passo a Passo. (Texto de Nanci Valadares mencionando o evento "Projeto in Progress Caju”). Rio de Janeiro, jan. e fev. de 1979. In Catalogue Raisonné n. doc. 0056.79.

286 Oiticica, Hélio. MEMORIANDO DELIRIUM AMBULATORIUM (Manifesto Caju). Rio de Janeiro, 11 de abril a 7 de outubro de 1979. in Catalogue Raisonné n. doc. 0114.79.

287 O Caju representa o "passado imperial (tem a casa de D. João VI que mais parece um chiqueiro caindo aos pedaços): é o BURACO DA LACRAIA: é o cemitério: é porto-cais com pinta de ser emergência e clandestinidade ao mesmo tempo: é militar: é hospital de tuberculosos; daí, diz Hélio, a proposta em aberto para o que der e vier. Valadares, Nanci. Rio Passo a Passo. (Texto de Nanci 
desde sempre em sua trajetória como "meditação dos momentos transitórios de vidacriação"288. Em seu Memorando, ao considerar a cidade em sua complexidade de regiões e ambiências distintas, Hélio alinha-se mais uma vez à abordagem situacionista da cidade, a qual é constituída por "zonas de climas psíquicos definidos"289. Ao convidar as pessoas a um caminhar lúdico pela região degradada do Caju, abordando e tomando o bairro como um playground 290 , Hélio também procura, a partir de "um comportamento lúdico-construtivo"291, desmistificar a ideia de que "ruas elegantes dão um sentimento de satisfação e que ruas pobres são deprimentes"292.

abordar tomar o bairro do CAJU como um playground bairrourbano para curtir os achados: achar-play: esse achar-abordarpenetrar é sem fim: não só é ele performado in progress como por etapas de acordo com participantes / propositores / proposições feitas / abordagens feitas / abordagens sugeridas / programas limitados e-ou abertos propostos / ideias formuladas / etc.: O CAJU É O GROUND: A PARTICIPAÇÃO DOS PARTICIPADORES FAZ O PLAY 293.

Em delirium ambulatorium Hélio reafirma a ideia de uma 'construção de situação', chega a grifar a importância de que tudo que seja feito ou proposto nessas experiências, não seja algo que se reduza ao "contemplativo ou ao espetáculo: que sejam instaurações situacionais” 294 . A aproximação, sobretudo, à prática da deriva situacionista, não se limita à concepção coletiva da proposta, em que várias pessoas

Valadares mencionando o evento "Projeto in Progress Caju”). Rio de Janeiro, jan. e fev. de 1979. In Catalogue Raisonné n. doc. 0056.79.

288 idem.

289 Debord, Guy. Introdução a uma crítica da geografia urbana. Les Lèvres nues, n. 6, 1955.

290 Oiticica, Hélio. Um breve relatório sobre o primeiro de uma série de acontecimentos. (Relatório sobre Acontecimentos Poético-Urbanos no Rio de Janeiro: Kleemania, 18 de dezembro de 1979 - parte do Programa in Progress Caju. Rio de Janeiro, 18 de dezembro de 1979. In Catalogue Raisonné n.doc. 0031.79 .

291 Debord, Guy. Teoria da Deriva. Is nº 2, dezembro de 1958 [1956].

292 Debord, Guy. Introdução a uma crítica da geografia urbana. Les Lèvres nues, n. 6, 1955.

293 Oiticica, Hélio. Um breve relatório sobre o primeiro de uma série de acontecimentos. (Relatório sobre Acontecimentos Poético-Urbanos no Rio de Janeiro: Kleemania, 18 de dezembro de 1979 - parte do Programa in Progress Caju. Rio de Janeiro, 18 de dezembro de 1979. In Catalogue Raisonné n.doc. 0031.79 .

294 Oiticica, H. Para acrescentar ao texto de NANCI. (informações para acrescentar ao texto "O Rio passo a passo” de Nanci Valadares). Rio de Janeiro, 3 de fevereiro de 1979. In Catalogue Raisonné $\mathrm{n}^{\circ}$ doc. 0055.79 . 
'rejeitando por um período mais ou menos longo, os motivos de se deslocar e agir que costumam ter com os amigos, no trabalho e no lazer, entregam-se às solicitações do terreno e das pessoas que nele venham a encontrar'295. O delirium ambulatorium relaciona-se, sobretudo, à ideia de jogo, presente na abordagem lúdica do espaço urbano que toma a cidade como um labirinto. A definição situacionista de jogo está de total acordo às ideias desenvolvidas por Johan Huizinga em Homo Ludens: o jogo como elemento da cultura. Segundo Huizinga, "o jogo realiza, na imperfeição do mundo e na confusão da vida, uma perfeição temporária e limitada"296. Declaradamente influenciados pela ideia de jogo desenvolvida por Huizinga, os situacionistas acreditam que o elemento de competição deveria ser eliminado numa nova fase de afirmação do jogo, pois o "ganhar ou perder", quase inseparável da atividade lúdica, também está relacionado a todas as manifestações da tensão entre indivíduos, uma vez que estão ligadas à atual organização das forças produtivas:

O sentimento da importância de ganhar no jogo, quer se trate de satisfações concretas ou na maioria das vezes ilusórias, é o mau produto de uma sociedade má. Sentimento esse naturalmente explorado por todas as forças conservadoras, que o utilizam para disfarçar a monotonia e a atrocidade das condições de vida que impõem aos outros $^{297}$.

A crítica situacionista centrada na vida cotidiana diz respeito a todo um arsenal material disponível para a sociedade, vendido como ideia de felicidade, ideia esta inata na burguesia e mantida por um sistema publicitário, que transforma a vida num jogo pobre. Portanto, 'combater a influência dos métodos de propaganda do capitalismo evoluído', 'opondo-se concretamente aos reflexos do modo de vida capitalista', 'destruindo a ideia burguesa de felicidade', esteve sempre na ordem do dia dos situacionistas, que viam a necessidade de preparar uma ação ideológica consistente para a transformação da vida num jogo integral apaixonante.

\footnotetext{
295 Debord, Guy. Teoria da Deriva. Is no 2, dezembro de 1958 [1956].

296 Huizinga, Johan. Homo Ludens: o jogo como elemento da cultura. Tradução João P. Monteiro. São Paulo: Perspectiva, 1971. [1938].

297 IS. Contribuição para uma definição situacionista de jogo. IS nº 1, junho de 1958.
} 
O delirium ambulatorium representa o ponto alto de um desenvolvimento que também vai ao encontro da transformação da vida num 'jogo integral apaixonante' que Hélio inaugura com seu Programa Parangolé. Neste processo, que tem seu início com as Capas na ideia do corpo e arquitetura, sobretudo, na liberdade do corpo na dança, foi sendo incorporado paulatinamente, também, o campo urbano, a partir dos Penetráveis, do Barracão e do Éden, e, por último, o território, principalmente, a partir da tomada deste campo urbano como um labirinto apropriado para a deambulação urbana, ao delirium ambulatorium. No desenvolvimento da ideia da vida como um jogo apaixonante, destaca-se ainda, a formulação do Crelazer, a negação da 'competição presente na categoria capitalismo-opressiva'298, para 'a aspiração da ideia de mundo que se cria no lazer, em torno dele, não como fuga, mas como ápice dos desejos humanos'299.

O jogo situacionista distingue-se do conceito clássico de jogo pela negação radical dos aspectos lúdicos de competição e da separação da vida corrente ${ }^{300}$. Estes aspectos, que ligam um novo conceito de jogo à vida cotidiana transformam as 'ruas' em potenciais campos de ação, particularmente, a partir da deambulação urbana, já diriam os situacionistas: "o que muda nossa maneira de ver as ruas é mais importante que o que muda nossa maneira de ver a pintura"301.

Pelo delirium ambulatórium a meditação é conduzida pelo corpo-pé: é a paixão-meditar-andar que no workshop fomental será maquetes-labirintos de topografias criadas: é a mesma paixão que me fez deslocar o campo pictórico do quadro para o espaço e destruir o pictórico empobrecido de séculos de parede para a proposição de um espaço-sítio novo e totalmente aberto à exploração criativa: àquilo que fez MALEVITCH declarar:

298 Oiticica, Hélio. Carta a Lygia Clark. Londres, 7 de junho de 1969. in Catalogue Raisonné n. doc. 0822.69.

299 Oiticica, Hélio. As possibilidades do Crelazer. Paris, 10 de maio de 1969. in Catalogue Raisonné n. doc. 0305.69.

300 Debord, Guy. Relatório sobre a construção de situações e sobre as condições de organização e de ação da tendência situacionista internacional. (Texto apresentado na conferência de fundação da Internacional Situacionista de Cosio d'Arroscio, julho de 1957).

301 idem. 
"Let rejection of old world of art be traced on the palms of your hands" (Deixe a rejeição do velho mundo da arte ser traçada nas palmas de suas mãos) ${ }^{302}$

302 Oiticica, Hélio. MEMORIANDO DELIRIUM AMBULATORIUM (Manifesto Caju). Rio de Janeiro, 11 de abril a 7 de outubro de 1979. in Catalogue Raisonné n. doc. 0114.79. (tradução livre da autora). 



\section{O Labirinto na Poética do Espaço}

(...) não se trata de fato somente de desenhar novas formas, mas de indicar novos projetos de vida ${ }^{303}$. Mario Perniola

O filósofo Mário Perniola desenvolve os conceitos a respeito do espaço urbano labiríntico partindo da premissa de que a forma urbana não é um recipiente neutro, ao contrário, é o instrumento e a condição de transformação da vida cotidiana. Seus argumentos dão conta de que não há como separar as condições nas quais uma sociedade vive da própria organização do espaço urbano, assim como não dá para separar a arte da vida ou considerar a arte apenas produção de obra, a arte deveria ser reconhecida como um projeto para o homem total ${ }^{304}$.

Nesta estreita relação dialética entre a forma ambiental e os modos de vida, a cidade seria a expressão mais direta da vida cotidiana de uma sociedade, que se revela na estrutura de um labirinto, cuja concepção formal está diretamente relacionada a complexidade desta organização social. Esta premissa já estava presente no início do século XX, no projeto Construtivista, que via a ligação entre revolução formal e revolução social, a abolição da arte como atividade separada e autônoma, e a configuração labiríntica do espaço como resultado da relação dialética entre formas e necessidades humanas ${ }^{305}$.

Porém, foi somente no final dos anos 1950, nas atividades da Internacional Situacionista, que o tema do urbanismo labiríntico encontrou seu aprofundamento

303 Os problemas do urbanismo não podem ser convenientemente abordados sem uma "imaginação sociológica" com base numa meditação histórico-filosófica que interpreta o desenvolvimento e os objetivos individuais da civilização: não se trata de fato somente de desenhar novas formas, mas de indicar novos projetos de vida. Esta "imaginação sociológica" é igualmente distante da utopia e da ideologia, da fantasia ahistórica e da justificativa do status quo: utopia e ideologia são antes singularmente convergentes e complementares, com base tanto na separação entre ideal e real, entre moral e ciência. Perniola, Mario. Appunti per una storia dell'urbanistica labiríntica. In: Rivista di Estetica. Ano XIII, Volume II, maio - agosto de 1968. p. 240-241. (tradução livre da autora)

304 .ibid.

305 ibid. 
sistemático. Como instrumento central para a construção de todo um ambiente, os situacionistas desenvolveram o Urbanismo Unitário 306: "teoria do emprego conjunto de artes e técnicas que concorrem para a construção integral de um ambiente em ligação dinâmica com experiências de comportamento"307. Segundo os situacionistas, a tríade o urbanismo unitário, comportamento experimental e construção de situação, apontam para um primeiro terreno em direção à mudança na vida cotidiana, enquanto que o termo unitário advém da posição contrária à separação moderna de funções baseadas na Carta de Atenas. Em oposição a cidade separatista e as formas funcionalistas da sociedade moderna que aparecem como expressão máxima do avanço técnico e que tendem à homogeneização dos espaços urbanos, os situacionistas defendem uma ambiência unitária, a construção de um ambiente que se dá em consideração ao comportamento dos indivíduos, não somente construído em oposição ao funcionalismo, mas, sobretudo, contra as técnicas atuais que excluem completamente 'o jogo'.

O conceito de urbanismo unitário relaciona-se diretamente a concepção formal de um labirinto unitário, que se distingue substancialmente dos conceitos clássicos de labirinto. Paolo Santarcangeli, em Il libro dei labirinti - Storia di um mito e di um símbolo ${ }^{308}$, apresenta duas vertentes conceituais de labirinto, a místico-religiosa e a iluminista. Por sua vez, Mario Perniola explica um terceiro conceito de labirinto, o 'unitário', que surge como crítica aos dois primeiros.

Em linhas gerais, no conceito místico-religioso, o labirinto é visto como um caminho pleno de obstáculos e dificuldades por onde a alma deve percorrer para alcançar sua salvação, somente alcança a salvação àquele que encontrar o centro do labirinto. Este conceito está relacionado aos ritos de iniciação, garante regeneração espiritual, estado de graça e o nascimento de um novo mundo para aquele que percorrer o labirinto até o fim. Sua representação gráfica apoia-se particularmente na religiosidade ocidental e cristã, por isso, observa-se no final da Idade Média, o símbolo do labirinto presente, por exemplo, na catedral gótica francesa ${ }^{309}$. O segundo conceito,

\footnotetext{
306 O termo urbanismo unitário foi criado pela Internacional Letrista, em 1956. In Home, S. Assalto à cultura. Utopia subversão guerrilha na (anti) arte do século XX. Tradução: Cris Siqueira. São Paulo:

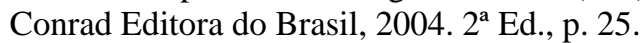

307 IS. Definições. Revista Internacional Situacionista, nº 1 , junho de 1958.

308 Santarcangeli, P. Il libro dei labirinti - Storia di um mito e di um símbolo. Firenze, Vallecchi, 1967. 309 idem.
} 
iluminista, é de origem grega e relaciona-se à versão helênica do mito de Teseu e do Minotauro. Neste mito, o labirinto é despido de todo caráter sagrado. Quem habita o labirinto é o Minotauro, o monstro. A ele são atribuídas todas as iniquidades, a bestialidade, a luxúria, a avareza e a crueldade 310 . Só é possível sair do labirinto através do fio de Ariadne. Este conceito iluminista de labirinto decai na Idade Média e ressurge com a ciência moderna manifestando-se na sua versão mais pura e radical: nos testes psicotécnicos. Observa-se os serviços militares apropriando-se deste conceito de labirinto para medir o senso de orientação dos recrutas, representando a finalidade substancial do mito helênico a serviço do domínio e da opressão ${ }^{311}$.

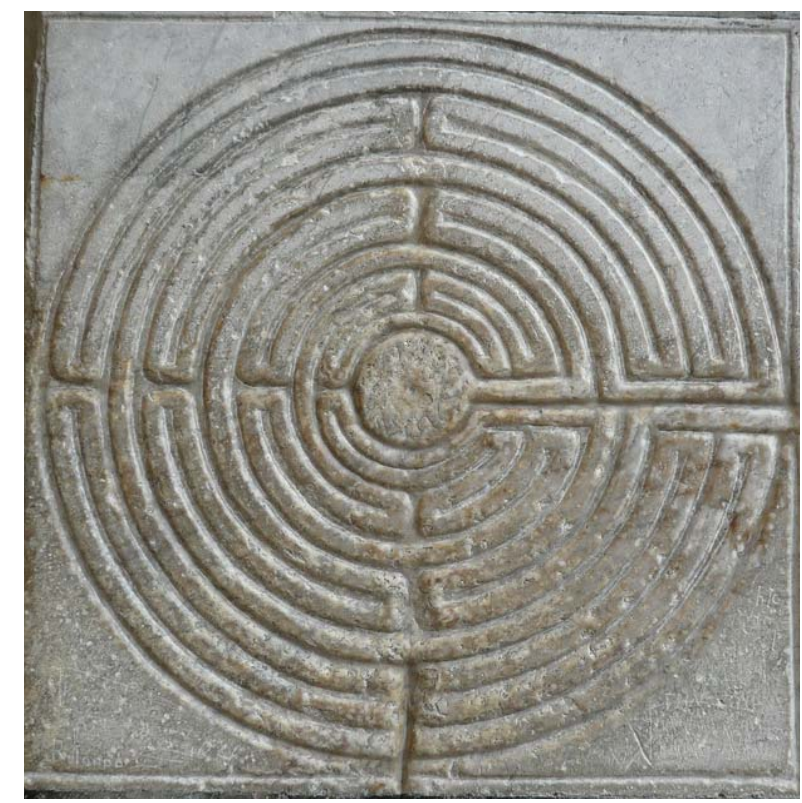

Figura 30 representação espacial de um labirinto clássico.

A crítica incutida no conceito de labirinto 'unitário' encontra-se na interpretação clássica de labirinto, que o encerra em sua concepção formal, movendo-se num horizonte mental que considera a arte uma atividade separada da vida. Perniola explica tal afirmativa a partir da própria representação gráfica do labirinto clássico, que possui sua estrutura dividida em centro e periferia. Nesta estrutura, a experiência labiríntica é reduzida, uma vez que o percurso ocorre em função da chegada. Enquanto que no conceito 'unitário' de labirinto, não há centro nem periferia, nem nenhuma regularidade: "il vero labirinto non lo si percorre; dentro il labirinto si vive"312.

310 Perniola, M. Appunti per una storia dell'urbanistica labiríntica. In: Rivista di Estetica. Ano XIII, Volume II, maio - agosto de 1968, p. 234.

311 ibid., p. 234-235.

312 ibid., p. 236. 
Segundo Mario Perniola a expressão mais concreta e próxima do labirinto unitário encontra-se na cidade medieval, a referência mais próxima de um espaço 'plenamente humano'. Entretanto, a progressiva afirmação da classe burguesa mercantil, que regulamentou o espaço urbano em larga escala segundo o 'espírito burguês', também transpôs para a concepção formal da cidade os mesmos atributos que a qualifica: ordenação, homogeneização e quantificação. Nesta organização urbana, na qual as necessidades humanas são subordinadas às exigências militares e do poder, a configuração espacial resulta numa concepção antilabiríntica do espaço. Em oposição ao urbanismo mais 'orgânico', sobretudo, contra as 'relações de vizinhança' sobre a qual se fundam as organizações medievais ${ }^{313}$, a cidade antilabiríntica é construída e reconstruída com base em princípios geométricos, e pelas exigências do tráfego, com o predomínio de linhas retas, uniformes e repetitivas, como expressão de um modo de vida formalista, anônimo e passivo.

Os situacionistas criticam justamente esta racionalização pragmática que está presente no planejamento urbano moderno, sobretudo, na separação de funções segundo a Carta de Atenas, pois esta seria a responsável pela monotonia da vida cotidiana, pela passividade e alienação da sociedade. Para os situacionistas, o urbanismo funcionalista atua como o produto e o produtor de uma sociedade que se 'auto-aliena', uma vez que os indivíduos encontram-se separados, seja pelas habitações 'pseudo-coletivas', seja pelo trânsito: "organização do isolamento de todos" (...) 'o avesso do encontro: um sugador das energias disponíveis para eventuais encontros ou para qualquer espécie de participação'314.

313 Entre os teóricos do 'efeito urbano', Thomas A. Reiner e seu 'introdutor' italiano Pier Luigi Crosta, criticam as 'relações de vizinhança', alegando que 'no âmbito da vizinhança não se formam somente relações de tipo positivo, mas também tensões, conflitos'. Opõem-se ainda a 'fechada e estática realização urbanística inspirada numa ideologia da comunidade', defendem que os efeitos de vitalidade e de variedade são fornecidos por uma grande concentração urbana. Entretanto, segundo Mario Perniola, a concepção labiríntica da cidade e o efeito urbano não são opostos, mas quase idênticos: "o erro de Munford está mais por ter considerado como vantagem da cidade medieval não somente as suas características urbanas mas também a sua pequena dimensão física. Sem dúvida que a condição fundamental para realizações humanas autenticas é uma prática íntima e cotidiana, porém, isto não exclui que se possa manifestar-se de diferentes formas a partir da vizinhança. A criação de novos capacitores sociais e o advento de uma situação seminômade são, por exemplo, tipos de organizações da vida cotidiana, por excelência dinâmicas, que escapam inteiramente tanto à Munford quanto à Reiner: 0 primeiro aparece condicionado a nostalgia rural, e o segundo por uma concepção muito técnica e neutra do urbanismo". in Perniola, Mario. ibid., p. 240. (tradução livre da autora).

314 Kotányi e Vaneigem, Raoul. Programa elementar do bureau de urbanismo unitário. Revista Internacional Situacionista, $\mathrm{n}^{\circ}$ 6, 1961. 
Em oposição as formas fixas os situacionistas aspiram uma estrutura dinâmica que multiplique a variedade do espaço para todo tipo de atividade lúdica, que seja propício para a prática da deriva contínua. Estas questões encontram-se reunidas nas explorações espaciais realizadas por Constant Nieuwenhuys, sobretudo em Nova Babilônia. O projeto da Nova Babilônia se desenvolve em paralelo a teoria do urbanismo unitário, consiste ao mesmo tempo numa nova forma criativa de transformação do espaço urbano que assume o mito dadaísta da "superação da arte", e num movimento à uma primeira tentativa de "superação da arquitetura"315.

\subsection{O Labirinto de Constant}

A trajetória artística de Constant é marcada por um grande interesse pelo urbanismo. Antes mesmo da fundação da Internacional Situacionista, a cidade já era para Constant, objeto de reflexões e crítica. Jean-Clarence Lambert explica que as experiências que Constant acumulou morando em Paris e em Londres em meados dos anos 1950, foram determinantes para sua concepção de cidade. Constant percebeu vivendo nessas cidades o espaço urbano como uma aglomeração caótica, um verdadeiro labirinto, iniciando à sua maneira a prática da deriva urbana ${ }^{316}$. O espaço urbano passou a ser compreendido por Constant, como um teatro de operações estéticas e como uma obra de arte coletiva realizada por toda a criatividade humana 317 . Além de suas experiências deambulatórias por Paris e Londres, outros momentos em sua trajetória foram determinantes para sua concepção de cidade, assumida de forma tão intensa, que o fez abandonar parcialmente o campo pictórico para se dedicar anos seguidos à elaboração de maquetes e planos que correspondessem à seu ideal urbano.

315 Careri, Francesco. Constant. New Babylon uma città nômade. Roma: Texto \& Immagine, 2001. p. 116.

316 Lambert, Jean Clarence. Constant e o Labirinto. In: Costa, X; Andreotti, L. (organizadores). Situacionistas. Arte, política, urbanismo. Situationist. Arts, politics, urbanismo. Catálogo de exposição. Museu d'Art Contemporani de Barcelona, 1996, p. 100.

317 Careri, Francesco. Constant. New Babylon uma città nômade. Roma: Texto \& Immagine, 2001. p. 23. 
Entre esses importantes acontecimentos, destaca-se sua relação com o arquiteto Aldo Van Eyck, a partir de 1953. Por conta da amizade com o integrante do Team X, Constant participou de algumas reuniões junto deste pequeno grupo de jovens arquitetos, o que possibilitou o contato mais direto à crítica ao pensamento moderno ortodoxo e ao planejamento urbano baseado na Carta de Atenas. O Team X propunha recolocar em seus projetos o homem real em oposição ao homem 'ideal' de Le Corbusier (o Modulor), procurando ao invés de um coletivo ideal, considerar as questões das diferenças individuais.

Outro fator determinante em sua trajetória data de dezembro de 1956, quando Constant junto ao artista italiano Pinot Gallizio, conhece a cultura nômade numa visita à um acampamento de ciganos na cidade de Alba. Esta experiência o colocou pela primeira vez em contato com uma possibilidade real de se viver de forma diferente, descobrindo, a partir daquela cultura nômade, o aparato conceitual com o qual propõe colocar em crise os fundamentos sedentários da arquitetura funcionalista ${ }^{318}$. A imagem abaixo representa a maquete de um projeto para a comunidade de ciganos que Constant elaborou após sua experiência em Alba.

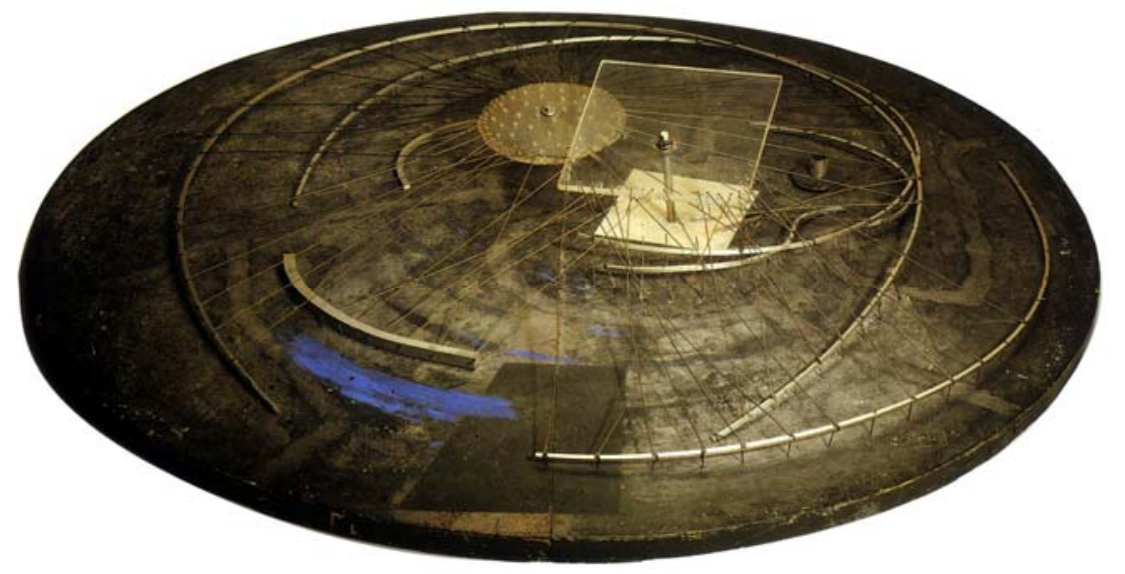

Figura 31 Constant. Maquete para um acampamento de ciganos, 1958.

Além desses acontecimentos, teve papel fundamental em sua trajetória sua proximidade com os letristas em 1956, quando ainda integrava o grupo Cobra. Os letristas colocavam-se em oposição ao funcionalismo racionalista que imperava nas cidades, e buscavam uma nova atividade criativa, experimental, que pudesse transformar o espaço funcional e racional da cidade num espaço apaixonante, porém, lhes faltavam um terreno de ação que representasse toda essa oposição.

318 Careri, F. New Babylon uma città nômade. Roma: Texto \& Immagine, 2001. p. 116. 
Estes fatores foram determinantes na trajetória de Constant, que passou a se dedicar, a partir da formação da IS, à arquitetura e ao projeto de uma cidade nômade, a Nova Babilônia (New Babylon). As maquetes da Nova Babilônia representam a visão tridimensional de um novo espaço para uma nova sociedade, presente também em suas pinturas. O projeto da Nova Babilônia foi apresentado na Bienal de Veneza em 1966.

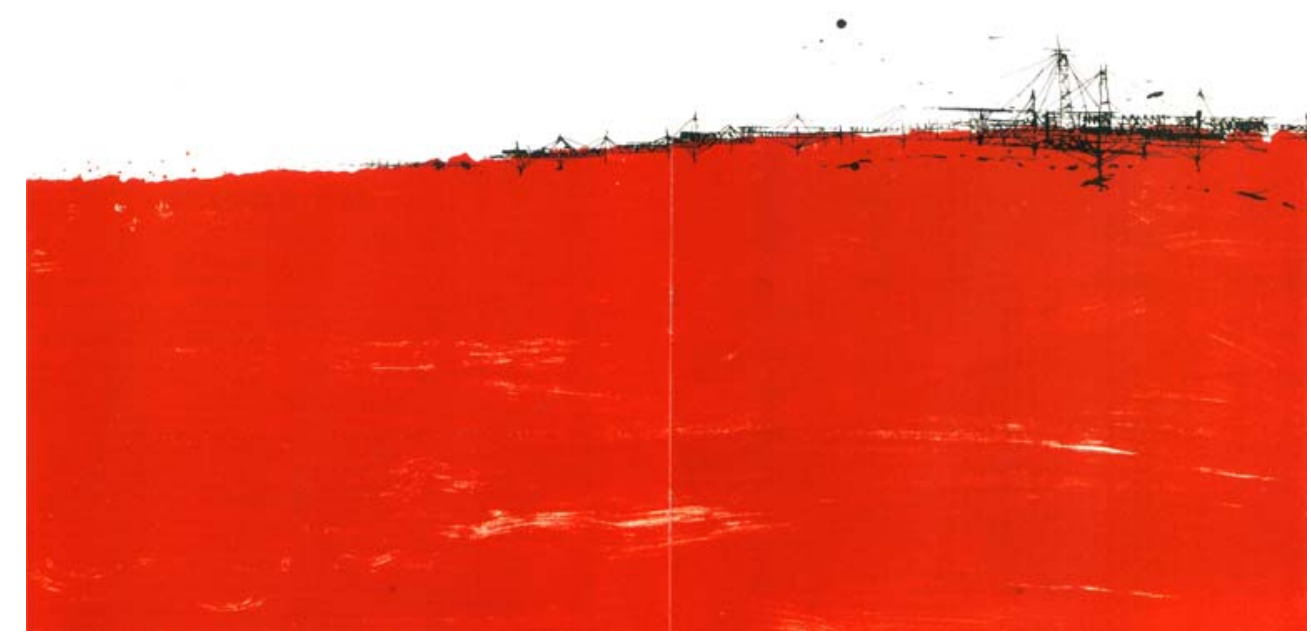

Figura 32 Constant. Litografia. Nova Babilônia, 1963. Costa, Xavier; Andreotti, Líbero. (organizadores). Situacionistas. Arte, política, urbanismo. Situationist. Arts, politics, urbanismo. Catálogo de exposição. Museu d’Art Contemporani de Barcelona, 1996. p. 148149.

Os conceitos em Nova Babilônia foram fundados a partir da ideia de um mundo sem fronteiras, livre, sem armas, que propiciasse uma mobilidade permanente, sem limites ${ }^{319}$. O nomadismo presente em Nova Babilônia reflete a recusa ao sistema de produção capitalista, ao sistema de acumulação de bens da propriedade privada, e às fronteiras étnicas e econômicas. Em oposição as concepções urbanísticas destinadas à sociedade utilitarista que constroem espaços partindo da noção de 'orientação', objetivando encurtar distâncias e 'ganhar tempo', Constant propõe um espaço móvel, variável, propício ao jogo, à aventura e à exploração, que resulta na concepção labiríntica do espaço. Por tanto, Nova Babilônia reflete ainda a expressão de uma sociedade lúdica e criativa, que conduz à dinamização do espaço e do tempo, e à conversão do espaço em um objeto de jogo, colocando por terra toda e qualquer ideia de 'orientação'. A ideia de jogo presente em Nova Babilônia, como resultado da

319 Careri, Francesco. New Babylon uma città nômade. Roma: Texto \& Immagine, 2001. 
atividade lúdica generalizada, também vem reafirmar a forma ideal do "não trabalho" e de um estado de espontaneidade reconquistado por esta nova sociedade.

A Nova Babilônia encontra-se em acordo aos princípios do urbanismo unitário, rejeita a concepção clássica de labirinto, que reduz as possibilidades do percurso e das escolhas, uma vez que no labirinto clássico, a planta apresenta um trajeto mais longo entre a entrada e o centro fazendo com que algumas partes acabem sendo pouquíssimas vezes visitadas ou apenas visitadas uma única vez, explica Constant: mesmo considerando a existência de labirintos mais complexos, que apresentam outros caminhos, sem saídas, pistas falsas que obrigam a voltar atrás, continuam sendo construções estáticas que determinam o comportamento, pois existe apenas um caminho 'certo' que conduz ao centro ${ }^{320}$.

Em oposição a forma clássica, Constant argumenta a favor do labirinto dinâmico, no qual o comportamento social também deve ser “labiríntico” e ser continuamente modificado ${ }^{321}$. Não há um centro onde se deva chegar, há inúmeros centros em movimento. "Não se trata de extraviar-se no sentido de "perder-se”, mas no sentido positivo de encontrar caminhos desconhecidos”322. O labirinto, como concepção dinâmica do espaço, oposto a perspectiva estática, é visto também, e sobretudo, como estrutura de organização mental e método de criação.

Lambert afirma que no projeto Die Welt als Labyrinth ${ }^{323}$, pensado para ser exposto no Stedelijk Museum de Amsterdã, concentra-se a maioria dos elementos da concepção 'laberintiana' do espaço, que Constant materializa em suas maquetes da Nova Babilônia, sobretudo, na maquete do Setor Amarelo, destinado a zona de jogo.

320 Constant. The principle of disorientation. In: Costa, X; Andreotti, L. Situacionistas. Arte, política, urbanismo. Situationists. Arts, politics, urbanism. Catálogo de exposição. Museu d'Art Contemporani de Barcelona, 1996. p. 87.

321 Lambert, Jean-Clarence. Constant and the labyrinth. In: Costa, Xavier; Andreotti, Líbero. Situacionistas. Arte, política, urbanismo. Situationists. Arts, politics, urbanism. Catálogo de exposição. Museu d'Art Contemporani de Barcelona, 1996. p. 95.

322 Constant. The principle of disorientation. In: Costa, Xavier; Andreotti, Líbero. Situacionistas. Arte, política, urbanismo. Situationists. Arts, politics, urbanism. Catálogo de exposição. Museu d'Art Contemporani de Barcelona, 1996. p. 87.

323 Die Welt als Labyrinth consistia em transformar em labirinto as salas 36 e 37 do Stedelijk Museum no mesmo momento em que uma equipe situacionista empreenderia uma deriva sistemática na zona central da cidade de Amsterdã. in Lambert, Jean-Clarence. Constant and the labyrinth. In: Costa, Xavier; Andreotti, Líbero. Situacionistas. Arte, política, urbanismo. Situationists. Arts, politics, urbanism. Catálogo de exposição. Museu d’Art Contemporani de Barcelona, 1996. p. 101. 


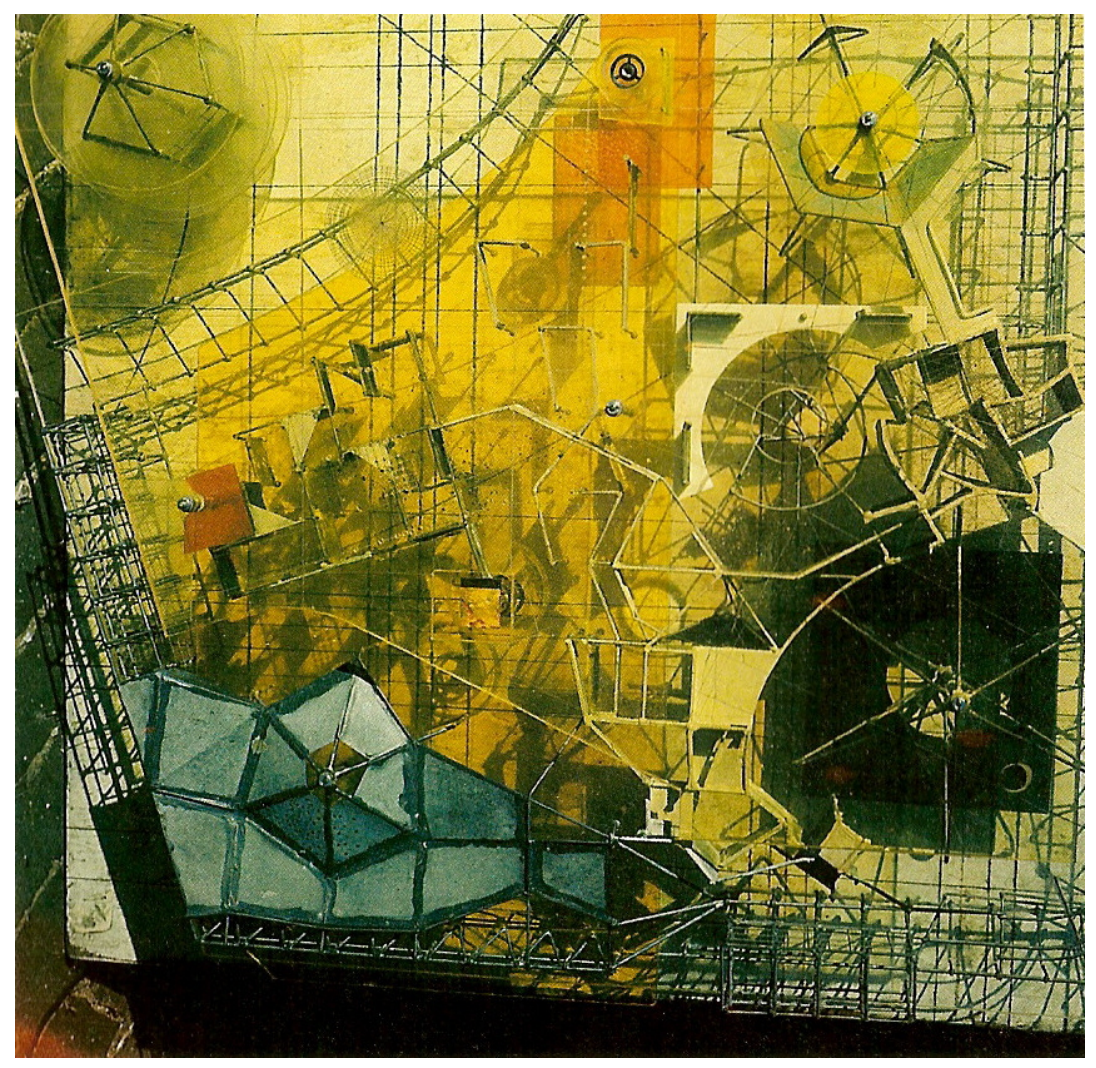

Figura 33 Constant. Setor Amarelo 2, 1958.

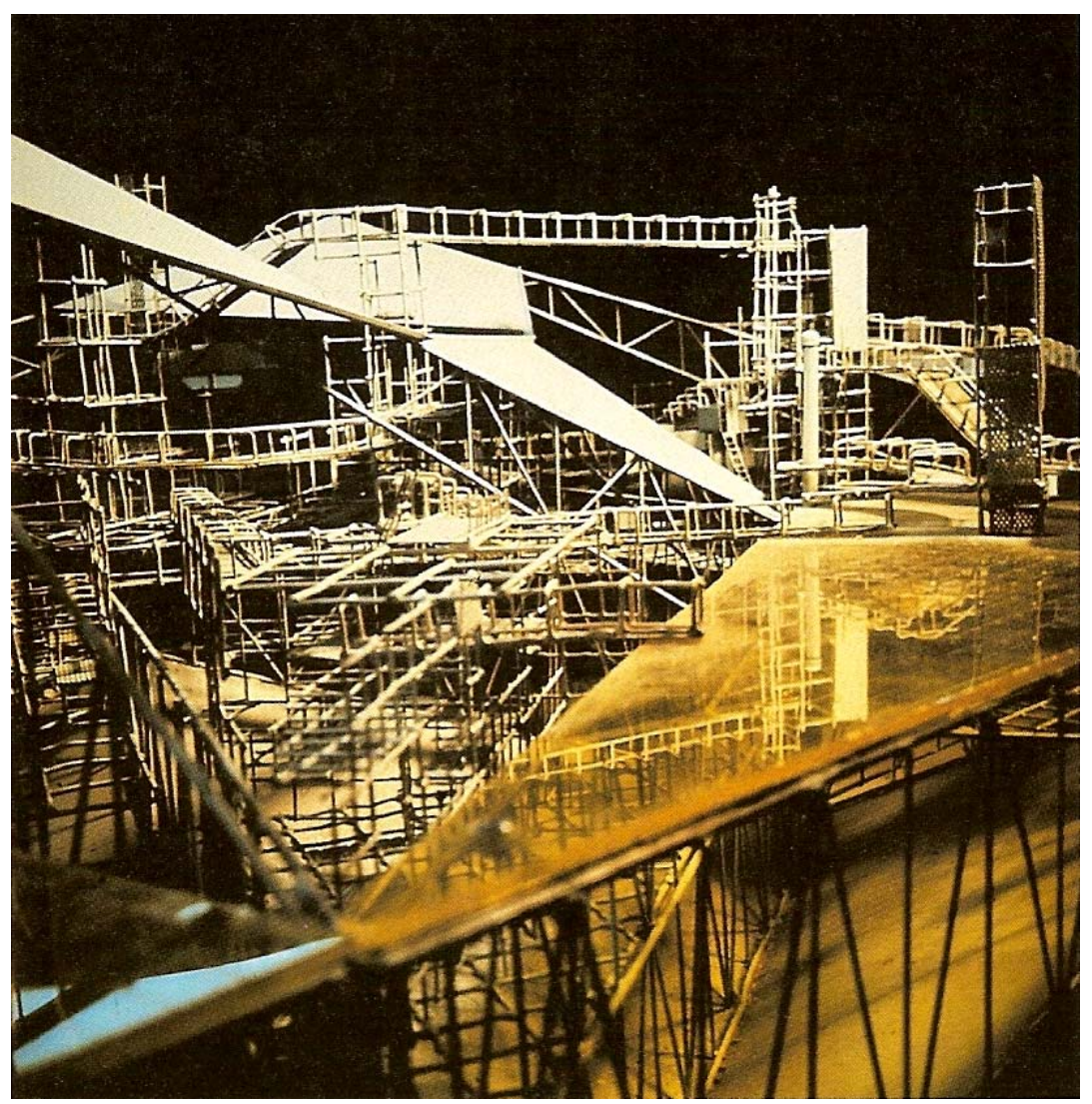

Figura 34 Constant, Grande Setor Amarelo 4. 
Constant explora tanto em suas maquetes quanto em suas litografias o 'jogo' do labirinto como apropriado para uma vivência urbana apaixonante. Lambert chega a afirmar que o tema do labirinto foi o grande 'mito diretor' de Constant, presente em tudo que concebeu, imaginou e criou. Uma série de litografias intituladas Labyrismes, realizadas em meados dos anos 1960, também apresenta o labirinto como conceito e forma 324 .

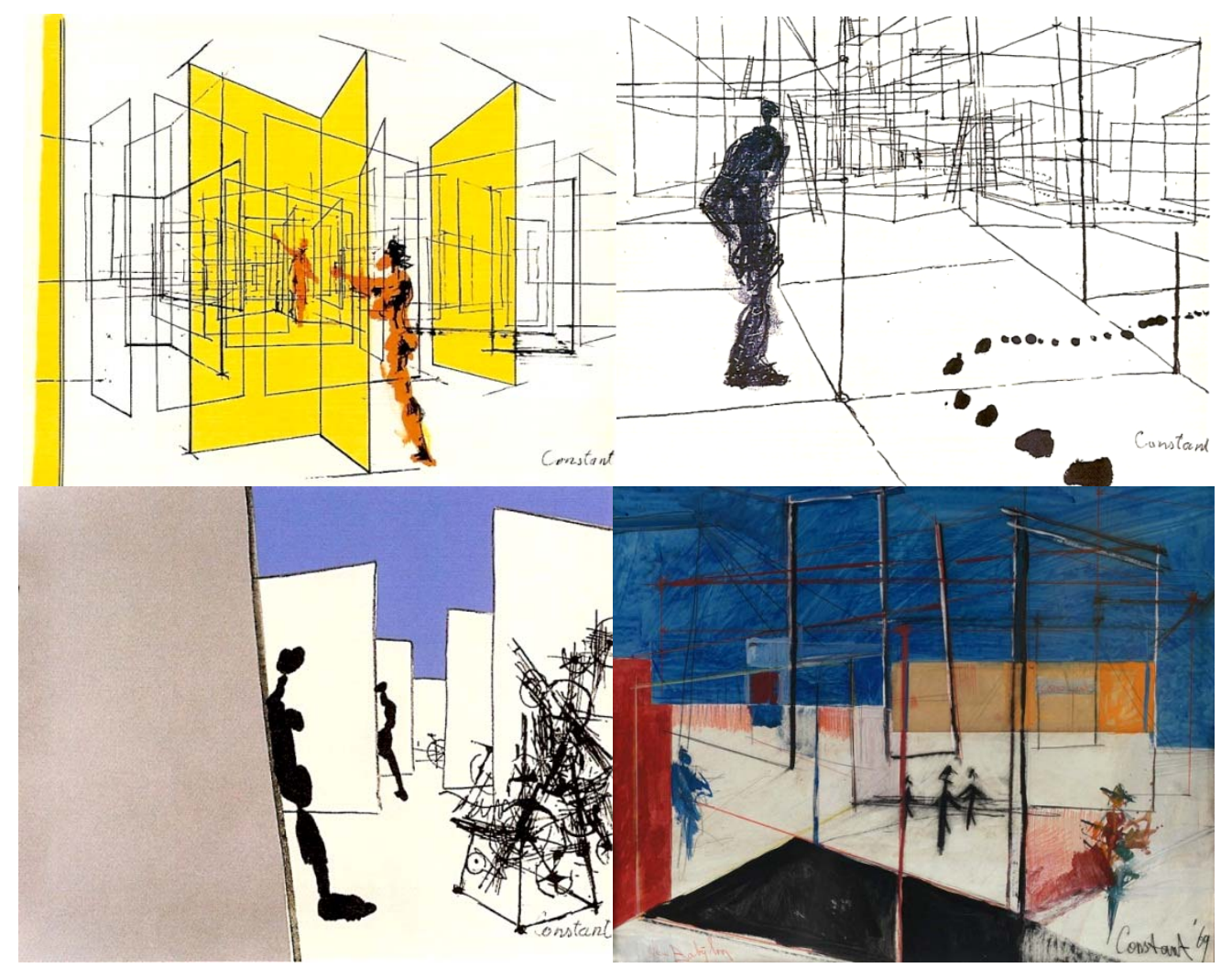

Figura 35 Constant, Labyrism, Litografias e Aquarelas. 1969.

Além de Nova Babilônia representar o projeto que mais investigou as possibilidades da deriva e da psicogeografia situacionista, ainda pode ser entendida como um dètournement em escala urbana, uma vez que subverte a ideia de espaço urbano a partir de uma 'construção superior do ambiente'.

324 Costa, X; Andreotti, L. Situacionistas. Arte, política, urbanismo. Situationists. Arts, politics, urbanism. Catálogo de exposição. Museu d'Art Contemporani de Barcelona, 1996. p. 104. 


\subsection{O Labirinto de Hélio Oiticica}

Hélio Oiticica amplia o campo pictórico ao transpor a cor para o espaço real, num processo que denominou 'desenvolvimento nuclear da cor'. Hélio abandona o modo euclidiano da representação a partir de seus Relevos Espaciais, desenhando um labirinto virtual, que será materializado, posteriormente, nos Núcleos e Penetráveis. O labirinto como concepção dinâmica do espaço em oposição a perspectiva estática correspondem ainda à organização mental e ao seu método de criação. Além disso, sua deambulação urbana, empreendida como "meditação dos momentos transitórios de vida-criação", é um comportamento tipicamente labiríntico, bem como, seus escritos intensamente produzidos durante toda sua trajetória, contos, memórias, poemas, crônicas, compõem, ao lado de seus estudos e reflexões a cerca do campo da arte e da cultura de seu tempo, um verdadeiro labirinto, são ideias e temas que apontam para diversas direções.

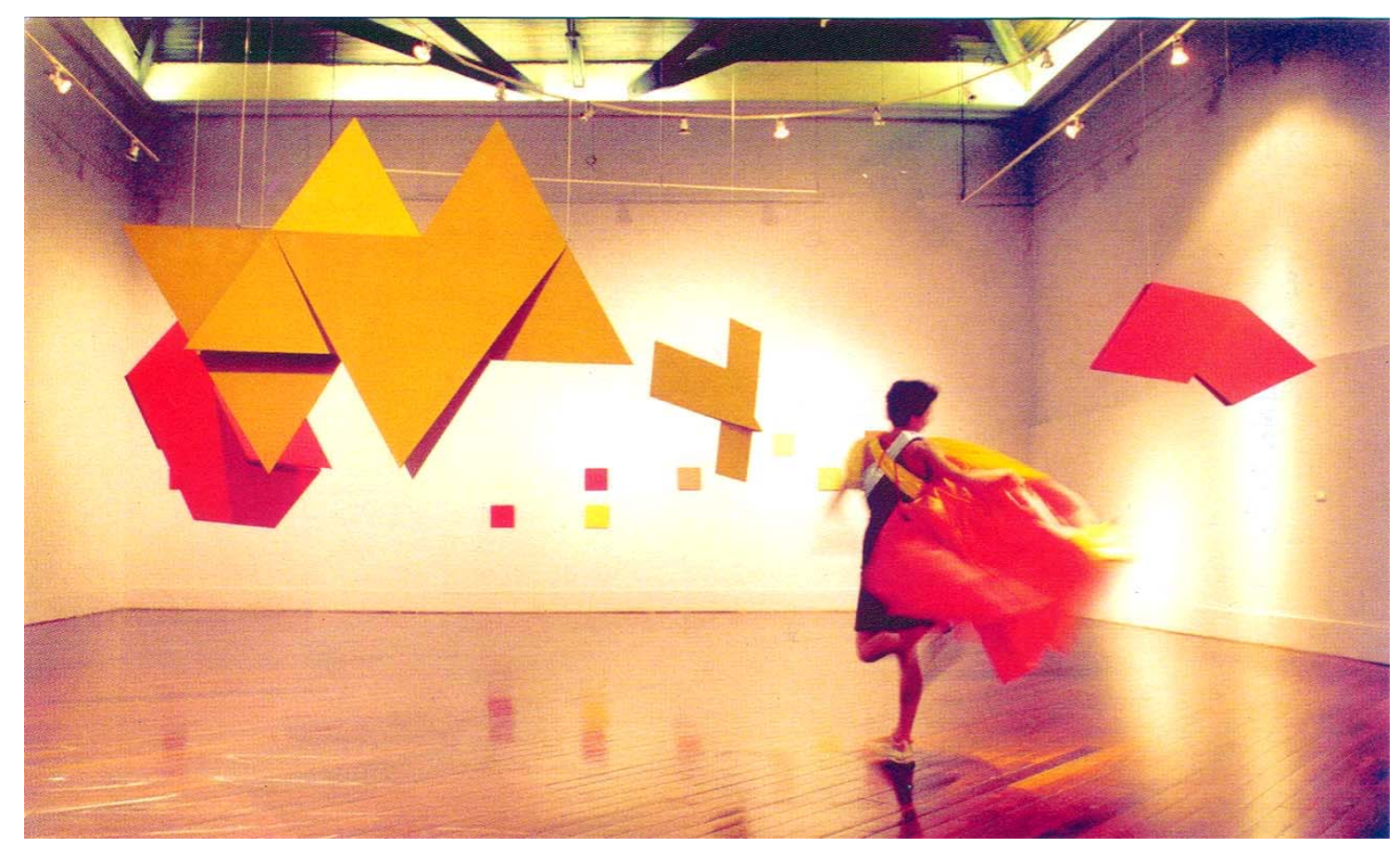

Figura 36 Hélio Oiticica. Relevos Espaciais e Parangolé. in Catalogue Raisonné n. doc. 2467.00. 


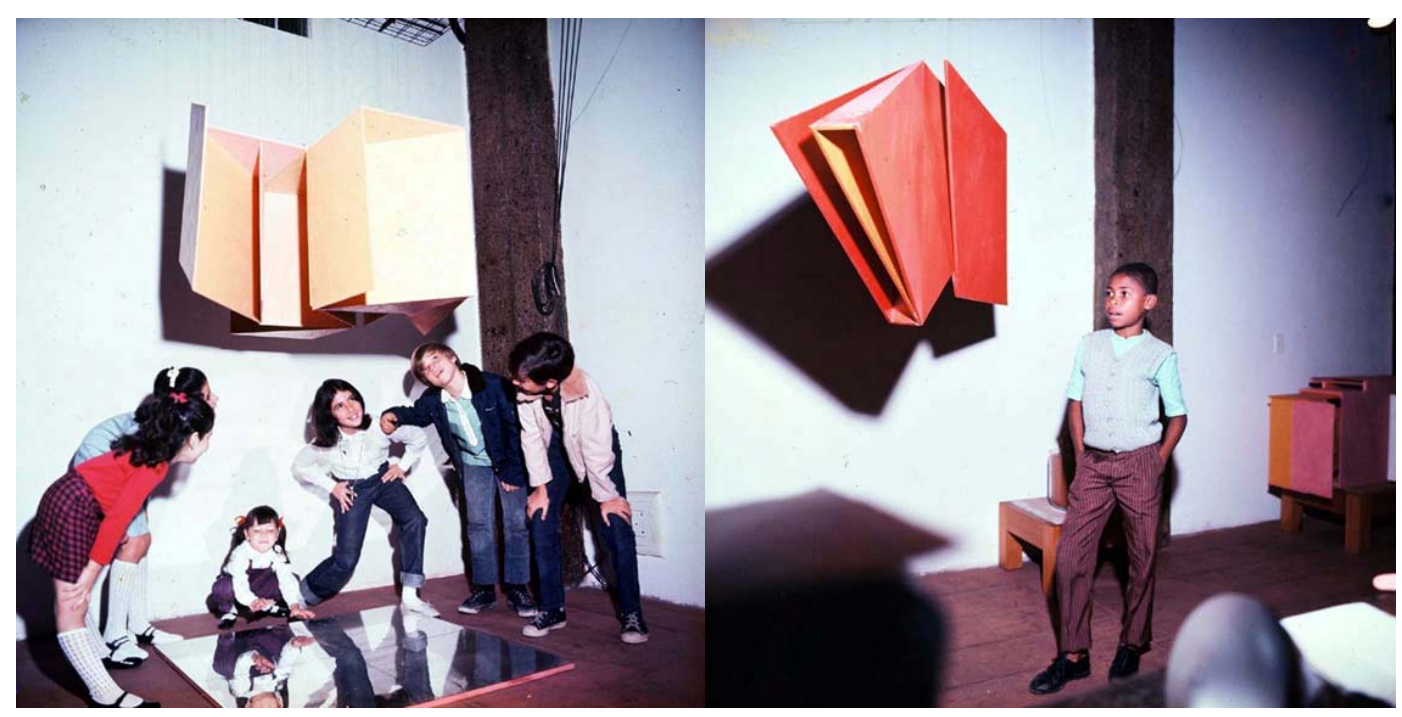

Figura 37 Hélio Oiticica. Relevos Espaciais. Exposição Galeria G4, 1966. in Catalogue Raisonné, n. doc. 1919.66

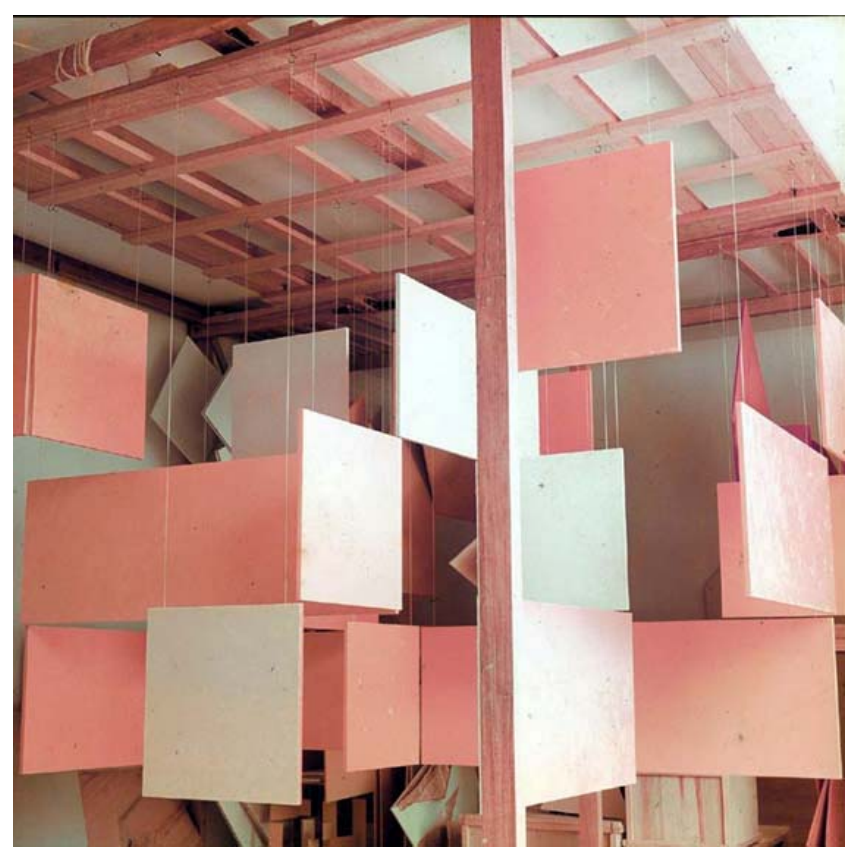

Figura 38 Hélio Oiticica. Núcleos, 1960. in Catalogue Raisonné n. doc. 2171/sd

O labirinto aparece na trajetória artística de Hélio tanto na sua forma conceitual como estrutural. Seu mosaico de escritos reflete a forma labiríntica de seu próprio desenvolvimento artístico, que se dá numa espécie de construção e reconstrução contínua, de ideias, projetos. Enquanto que do delirium ambulatorium surgem as séries de Penetráveis Labirínticos, Ninhos e Barracões, nos quais o elemento do labirinto aparece tanto como conceito, quanto como forma, encaminhando-se para o desenvolvimento 'estrutura-comportamento' com o Barracão. Esta 'estrutura- 
comportamento' relaciona-se diretamente à ideia de uma estrutura dinâmica, transformável conforme o comportamento, as ideias e a criatividade das pessoas, o aproximando do conceito 'unitário' desenvolvido pelos situacionistas. Porém, antes mesmo da ideia de uma 'estrutura-comportamento' formulada no Barracão, seus Penetráveis também já eram concepções complexas de labirinto.

O Penetrável Cães de Caça, de 1961, foi concebido como um verdadeiro jogo, uma estrutura com três saídas/entradas. No interior do labirinto foram inseridas algumas situações estrategicamente construídas, como o "Poema Enterrado" de Ferreira Gullar, o "Teatro Integral" de Reinaldo Jardim, e cinco "Penetráveis", de tal forma, que à medida que adentrasse ao labirinto estes elementos estéticos surgiriam, elevando o "espectador a uma participação estética"325. Este seria o seu "caráter mágico", ou seja, permitir àqueles que penetrassem ao labirinto a vivência de um outro plano que não o do cotidiano ${ }^{326}$.

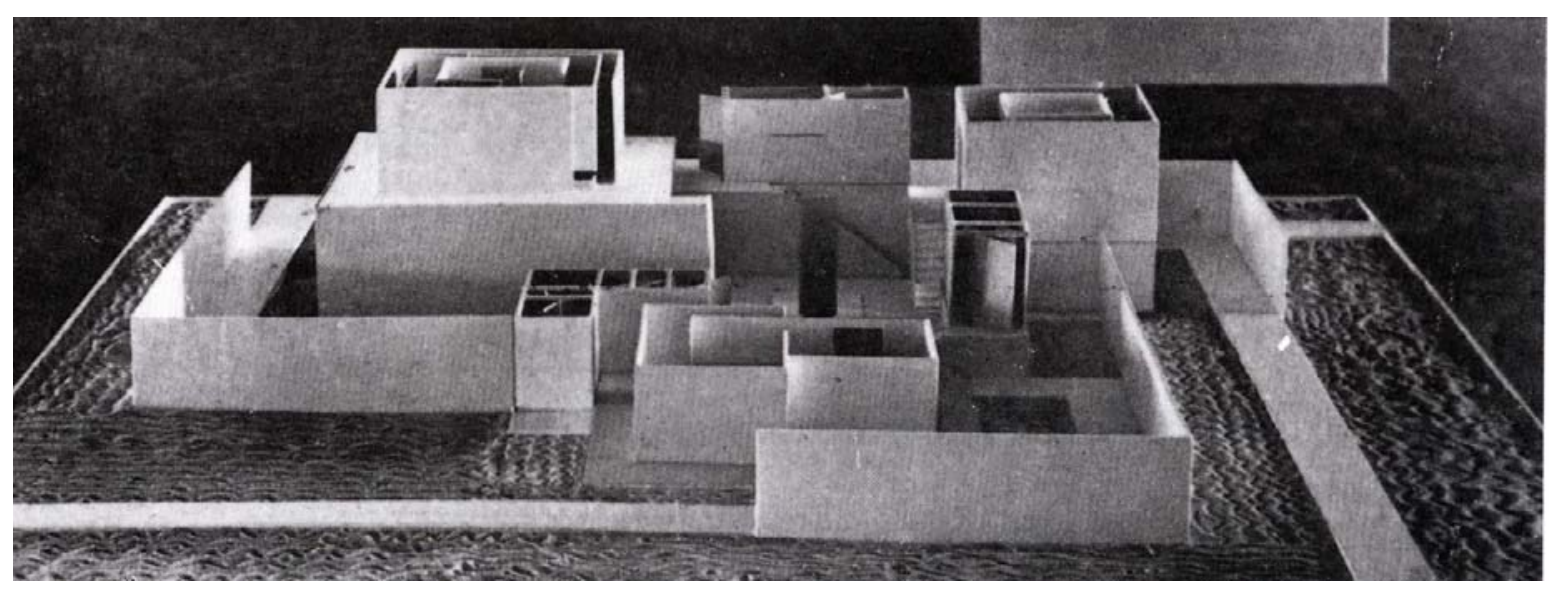

Figura 39 Hélio Oiticica. Projeto Cães de Caça, 1961. Acervo Projeto Hélio Oiticica.

Em 1961, Hélio escreveu em seu diário: “Aspiro ao Grande Labirinto”, mas foi em 1963, quando conheceu a favela da Mangueira, que incorporou em suas formulações o improviso e a espontaneidade na concepção de seus labirintos penetráveis. No lugar da maquete elaborada e projetada em seus detalhes, surge

325 Oiticica, Hélio. Projeto Cães de Caça e Pintura Nuclear. Transcrição de entrevista sobre exposição no MAM/RJ em novembro de 1961. Rio de Janeiro, 1 de novembro de 1961. Catalogue Raisonné, n. doc. 0024.61 .

326 Oiticica, Hélio. Neoconcretos falam de sua exposição. Jornal do Brasil. Rio de Janeiro, 21 de abril de 1961. Catalogue Raisonné, n. doc. 0576.61. 
Tropicália, 'construída de improviso, sem qualquer plano ou maquete anterior, apenas esquemas de montagem para as diferentes exposições'327.

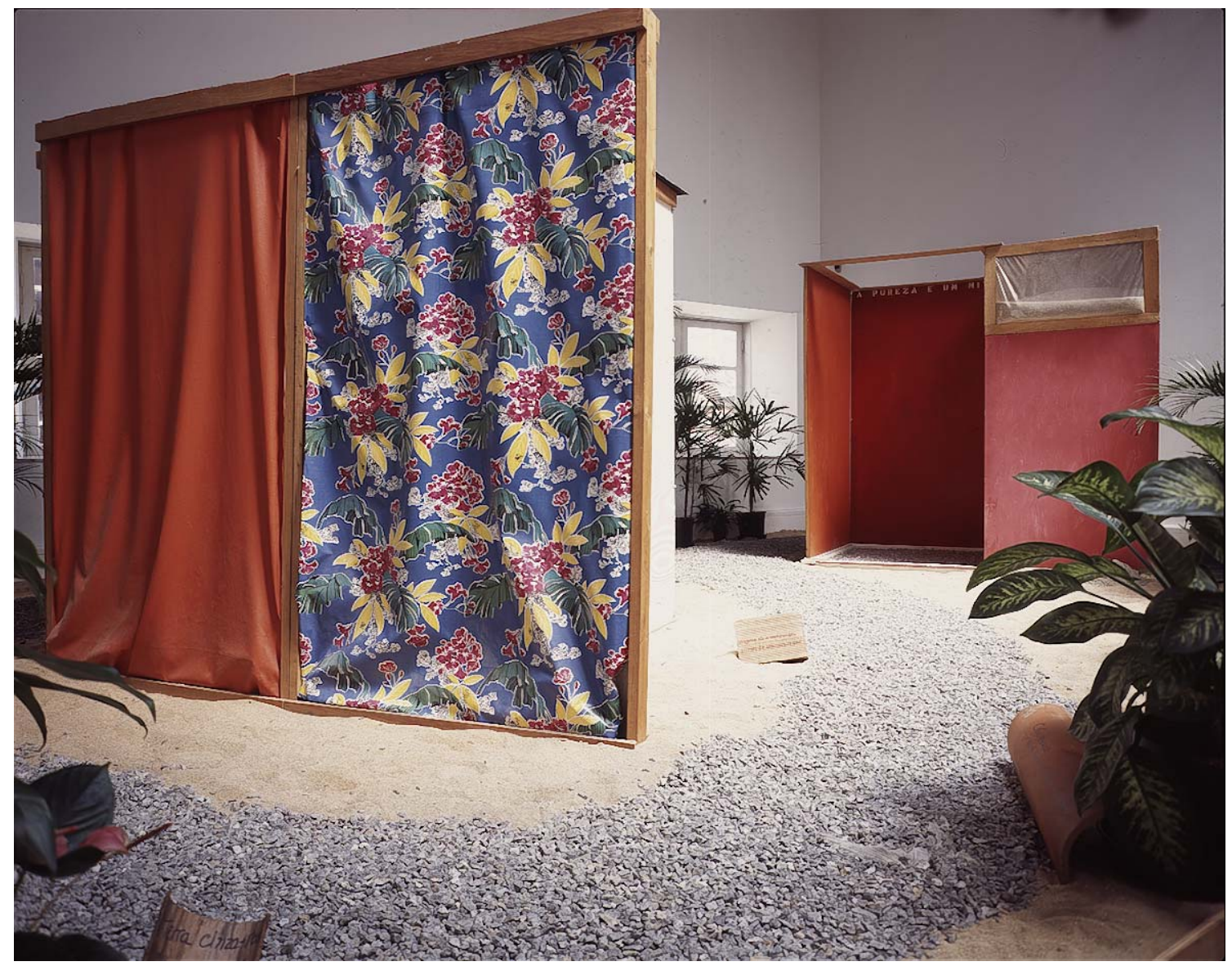

Figura 40 Hélio Oiticica. Tropicália. Acervo Projeto Hélio Oiticica.

No final dos anos 1960 Hélio passou a desenvolver ideias de "célulascomunitárias”, "lugar público labiríntico de vivências coletivas” e de "uma arquitetura transformadora de comportamento e construtora de espaços públicos para práticas descondicionadas”. Surgem daí os Ninhos, o Éden e o Barracão, que irão se nutrir ainda do conceito de Crelazer, formulado em Londres, principalmente, a partir de seu contato com o Exploding Galaxy e de sua experiência na Whitechapel. Em The Senses Pointing Towards a New Transformation, texto de 1969, Hélio explicita essas ideias a partir de 'células' que abrigariam uma comunidade de pessoas, uma 'comunidade experimental'. Em um barracão virtual chega a imaginar vivendo no mesmo ambiente Nietzsche, Cage, Debord, Artaud, Mallarmé, Burroughs e muitos outros, numa

327 Jacques, Paola Berenstein. A estética da Ginga A arquitetura das favelas através da obra de Hélio Oiticica. Rio de Janeiro: Casa da Palavra, 2003. p. 75. 
flexibilidade não só arquitetônica ou comportamental, mas também temporal, fundindo as palavras Barracão (em inglês, Barn) e Babylon, no termo “Barnbylon”328.

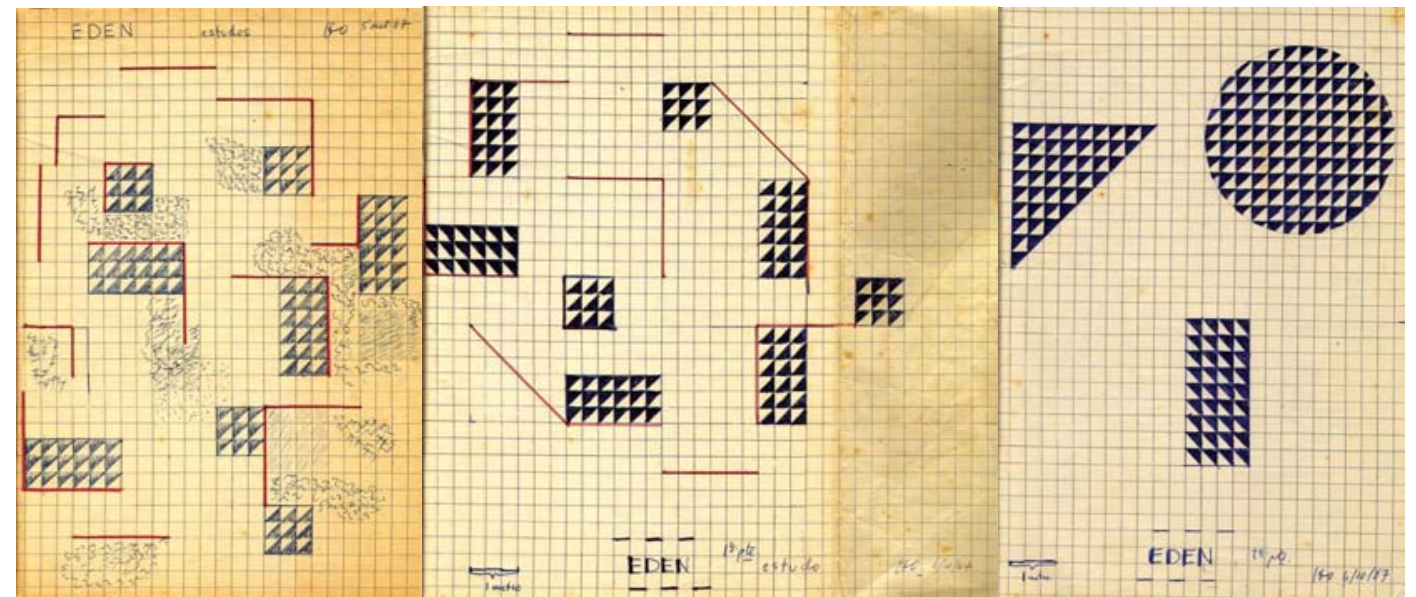

Figura 41 Hélio Oiticica. Estudos para o Éden. in Catalogue Raisonné n. doc. 1736.67.

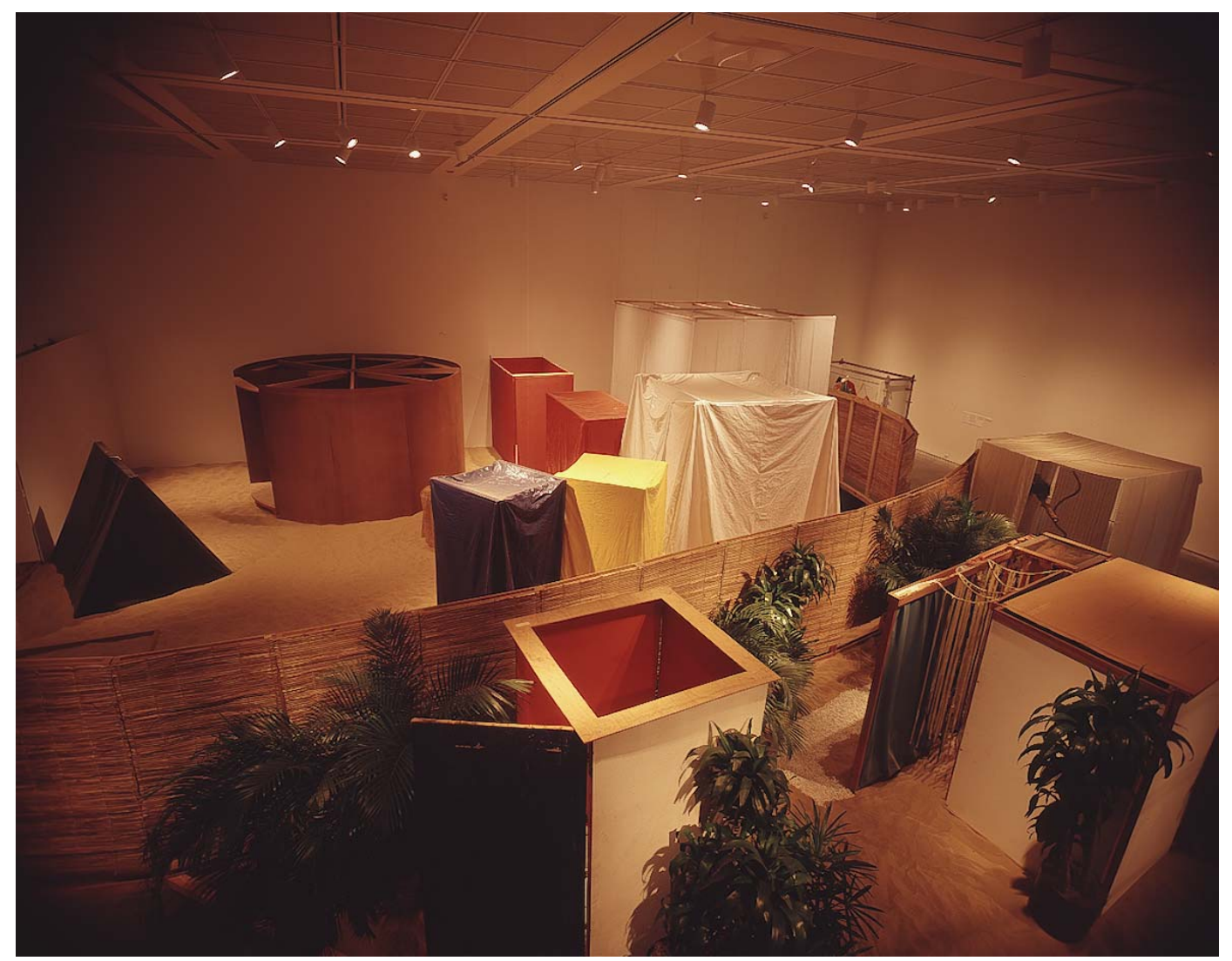

Figura 42 Hélio Oiticica. Éden. Acervo Projeto Hélio Oiticica.

O Barracão está relacionado diretamente com a moradia da favela, pois apesar de Hélio não ter tido a intenção de "imitar" a favela, pretendia uma arquitetura que

328 Oiticica, Hélio. The Senses Pointing Towards a New Transformation. Londres, 18 de junho a 25 de junho de 1969. in Catalogue Raisonné n. doc. 0486.89. 
mais se aproximasse de uma forma orgânica, um 'comportamento-estrutura.' O Barracão seria uma comunidade enorme construída pelas próprias pessoas ${ }^{329}$. A estrutura orgânica seria a mais adequada para abarcar uma maior liberdade de comportamento, Hélio pretendia um lugar para que as pessoas pudessem ler, ouvir música e etc.. Sua ideia de conforto estava distante daquela que dita a cartilha dos decoradores, do conforto padronizado. Sua ideia de aconchego aproximava-se do Ninho, pois desejava um lugar no qual fosse possível estabelecer uma relação sobretudo afetiva. Estas seriam as condições adequadas, segundo Hélio, para as pessoas criarem, de maneira mais primária e imediata ${ }^{330}$. Além disso, o projeto do Barracão indica uma estrutura orgânica, um modelo experimental do lazer como atividade positiva, onde as experiências ligadas ao comportamento transformariam o dia-a-dia em um campo experimental aberto ${ }^{331}$. Além da relação com a ideia de “células comunitárias” ou “comunidades experimentais”, o Barracão relaciona-se ainda à ideia de um “teatro experimental”.

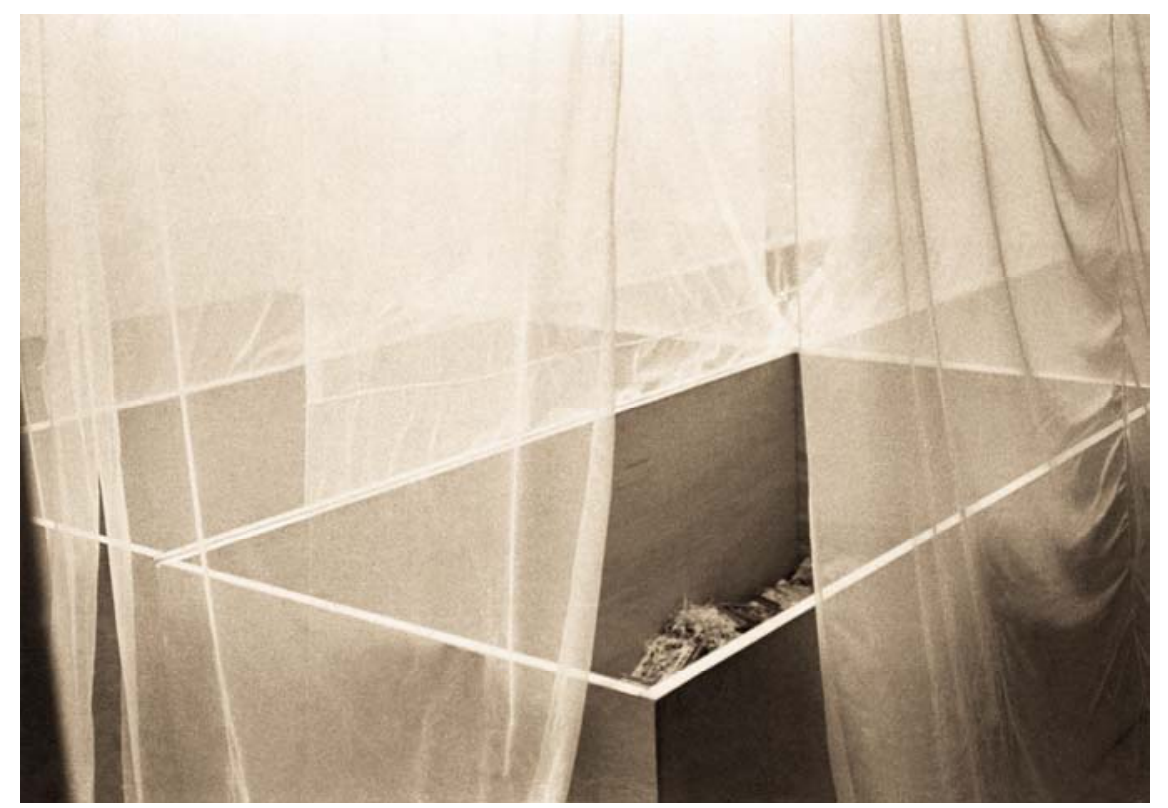

Figura 43 Hélio Oiticica. Ninhos. Acervo Projeto Hélio Oiticica.

Nos Penetráveis formulados no período em que vive em Nova York, Hélio explicita a partir da concepção do espaço labiríntico, uma estrutura 'não-espetáculo'. O

329 Oiticica, Hélio. in Entrevista de HO com Gilse Campos. Hélio Oiticica, uma arte sem medo. Jornal do Brasil. Rio de Janeiro, 29 de Janeiro de 1970. Catalogue Raisonné, n. doc. 0867.70.

330 Oiticica, Hélio. in Entrevista de HO com Gilse Campos. Hélio Oiticica, uma arte sem medo. Jornal do Brasil. Rio de Janeiro, 29 de Janeiro de 1970. Catalogue Raisonné, n. doc. 0867.70.

331 Notas publicadas na Folha de S. Paulo, 25.1.1986, p. 52. Op., Cit. Favaretto, Celso. A invenção de Hélio Oiticica.. p. 197. 
Penetrável Central Park, projeto destinado para o Central Park de Nova Iorque, bem como, o Penetrável PN16, elaborado para a Praça da República ${ }^{332}$, em São Paulo, são exemplos da ênfase dada por Hélio para a estrutura labiríntica como espaço propício à participação, na qual a 'desorientação' funcionaria como 'descondicionamento social', 'desalienação'.

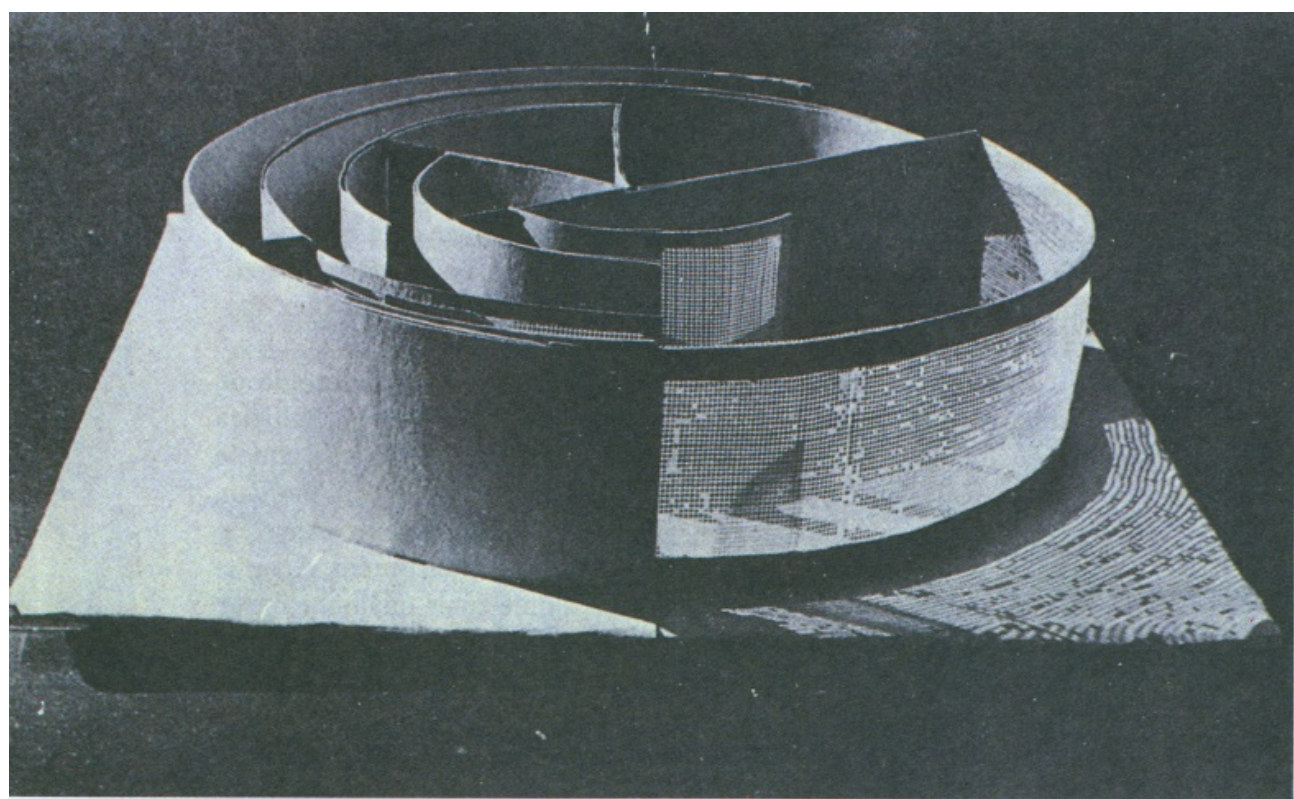

Figura 44 Hélio Oiticica. PN15, maquete projeto para Penetrável Auto-Teatro, NY, 1971. in Favaretto, Celso. A Invenção de Hélio Oiticica, p. 209.

A maquete para Subterrânea, executada também neste período, em 1971, vincula à concepção labiríntica do espaço a crítica à cultura brasileira. Em Subterrânea, conceito formulado em 1969, em Londres, Hélio procura compreender o que seria o underground brasileiro: "superar a ideia superficial de que uma atividade subterrânea seja algo excêntrico ou formal: uma nova modalidade de vanguarda"333. Subterrânea não diz respeito ao urderground americano, não se trata de algo que nasceu contra à cultura profissionalizada condicionada ao consumo, por isso não tem sentido dizer underground brasileiro, explica Hélio: "pois em relação à cultura de consumo americano-européia, a coisa já é automaticamente, aqui, underground"334.

332 O Projeto Central Park e o PN16 são discutidos na seção 2.2 A deambulação de HO em Nova Iorque.

333 Oiticica, Hélio. Subterrânea. Rio de Janeiro, 4 de setembro de 1970. in Catalogue Raisonné n. doc. 0289.70.

334 Oiticica, Hélio e Campos, Haroldo. Heliotapes (2). Nova Iorque, 27 a 28 de maio de 1971. (Entrevista com Haroldo de Campos feita por HO para publicação). in Catalogue Raisonné n. doc. 0396.71. 
Subterrânea, diz respeito a uma 'atividade experimental', 'crítico-criativa', que assume a marginalidade face ao "subdesenvolvimento" brasileiro ${ }^{335}$, porém que deveria assumir o sentido de uma comunicação universal, pois o conceito de uma 'cultura brasileira', de uma 'cultura nossa' é estreito e alienado, "exclui na maioria das vezes os significados relativos às manifestações dessa mesma cultura em outros contextos" 336 .

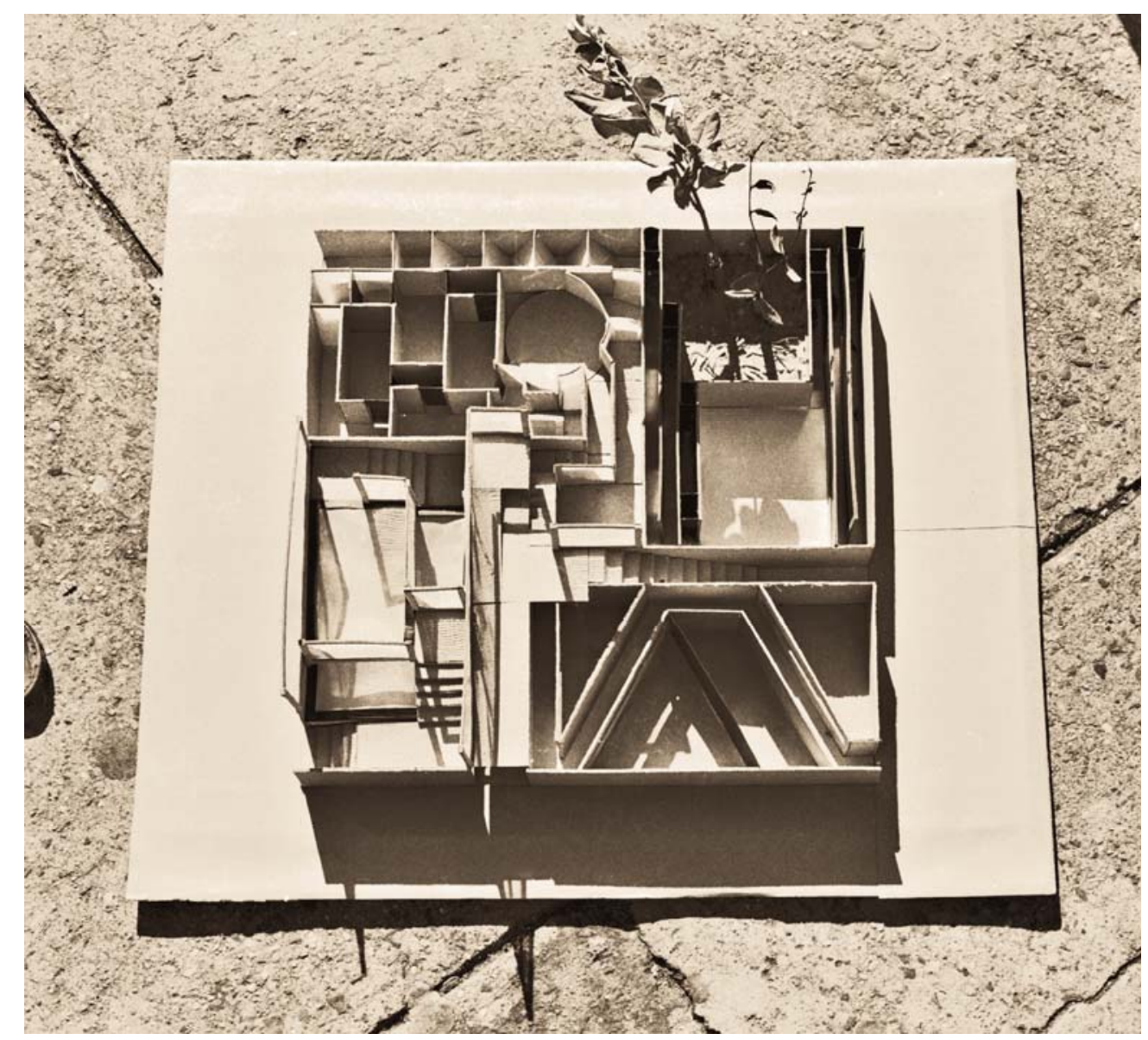

Figura 45 Hélio Oiticica. Subterrânea, maquete projeto 1, Tropicália. Nova Iorque, 1971. Acervo Projeto Hélio Oiticica

Na série Magic Square, formulada entre 1978 e 1979, Hélio explicita a forma labirinto como alusão à percepção de um novo mundo. Este novo mundo que nasce a partir da pintura no espaço, numa referência aos 'construtores' do começo do século, Kandinsky, Malevich, Tatlin, Mondrian, se resolve na estrutura do labirinto. Um dos últimos trabalhos que Hélio desenvolveu, Magic Square apresenta o labirinto como 'estrutura cor' no espaço, numa referência clara ao 'desenvolvimento nuclear da cor' do

335 Favaretto, Celso. A invenção de Hélio Oiticica. p. 201.

336 Oiticica, Hélio. Subterrânea. Rio de Janeiro, 4 de setembro de 1970. in Catalogue Raisonné n. doc. 0289.70 . 
início de sua trajetória, além de estrutura para a experiência da arte, para a vivência da cor. Reside aí seu caráter mágico, no labirinto, que ao conduzir à experimentação estética realiza a aproximação entre arte e vida.

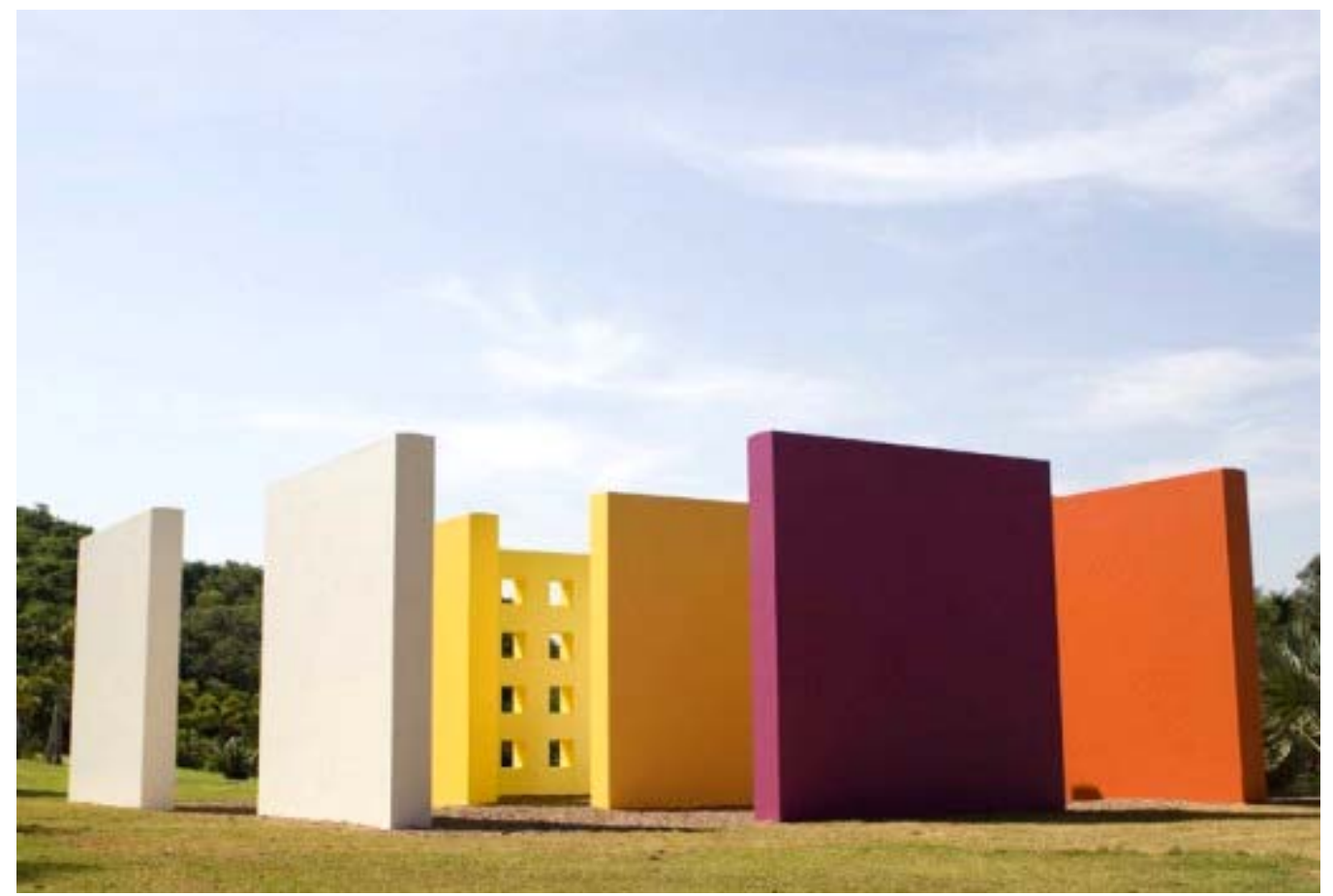

Figura 46 Hélio Oiticica. Magic Square nº5 - De Luxe. imagem:

http://www.inhotim.org.br/uploads/Obras/5f61cbc3b546e8007d601292a184f846_media.jpg 



\section{Conclusão}

Confirmar a proximidade das proposições de Hélio Oiticica com o pensamento situacionista, hipótese formulada no início deste trabalho, resultou numa verdadeira deambulação por um intrincado labirinto de relações. Tal qual Dédalo, apresentar um mapa desse labirinto, relembrando cada passagem, desvio e conexão parece ser a melhor figura de linguagem para explicar a tarefa a ser empreendida nestas 'conclusões'.

Dentre os vários pontos possíveis de se eleger como local de partida, inicio com o conceito de 'situação', conceito chave da Internacional Situacionista, que se conecta a todos os outros. No conceito de 'situação' está presente o 'espírito' contestador e político dos situacionistas, isto é, a 'construção de situação' corresponde à construção de um 'momento da vida', que deveria se dar a partir de uma 'organização coletiva', 'de uma ambiência unitária', 'e de um jogo de acontecimentos'. Essa definição já seria suficiente para compreendermos a similaridade entre essas questões com as elaboradas por Hélio Oiticica em seu Programa Parangolé, a começar pela própria experiência Parangolé, enquanto capas, tendas e estandartes, mas também, a partir de seus Penetráveis, Ninhos e Barracões: são 'formas experimentais de um jogo superior', no qual os 'espectadores', o 'público passivo' ou os 'figurantes' são transformados em 'vivenciadores', 'participantes'. Em carta a Luis Otávio Pimentel, de 5 de julho de 1971, Hélio Oiticica afirma que suas "experiências-situações" possuem relações óbvias com os situacionistas, além de referir-se às suas capas (parangolé) como capas-situação. Ou seja, além de seu declarado conhecimento sobre a IS e de suas ideias centrais, segundo a própria definição situacionista, Hélio poderia ser considerado um 'situacionista' pelo fato de 'perceber a necessidade objetiva de construir situações diante da carência da cultura' ou por ser um 'indivíduo que se dedica a construir situações'. Hélio assume a ideia de 'situação' como crítica às formas de organização capitalista que exclui os indivíduos da possibilidade de participação na construção da vida diária, acredita na 'simples manifestação da imaginação coletiva' e propõe exercícios de estruturas 'não-espetáculo' em detrimento à alienação do espectador. Hélio também está de acordo com as ideias desenvolvidas por Guy Debord, para o qual o 'espetáculo' produz um movimento perpétuo que distancia o homem de sua 
própria vida cotidiana, seja no trabalho, atividade inconsciente ou alienada, da qual lhe tiram toda subjetividade para lhe integrarem num sistema no qual passa a ser mais uma peça da engrenagem, seja no lazer, produzido pelo mesmo sistema que procura alcançar lucros em todas as esferas da vida humana, e que constrói um lazer falso, para o qual as pessoas pagam, na ilusão de saciarem um desejo que também é fabricado. Hélio conhece a teoria do espetáculo desenvolvida por Guy Debord e relaciona-a com seu próprio trabalho. Escreve em 5 de julho de 1971, em carta a Mário Pedrosa (e repete a mesma informação numa série de cartas que escreve neste mesmo período), que havia conhecido uma versão em inglês da La Société du Spectacle, comenta o quanto a teoria do espetáculo de Debord fazia sentido nas formulações do Éden "um pré-modelo de proposições para o lazer não repressivo", que deveria servir para o exercício lúdico, para o lazer criativo, o Crelazer, criar no lazer, a busca pelo prazer vivido no 'tempo livre'. A obra 'A Sociedade do Espetáculo' ainda é citada em diversos textos em que Hélio questiona não somente o problema da participação no 'mundo espetáculo', como também, o problema da diluição, ao constatar que os processos artísticos de natureza experimental tinham sido absorvidos no contexto 'artístico espetacular': seu Parangolé havia se transformado em "arte parangolé", o Ambiental em "arte ambiental" e Tropicália em "tropicalismo".

Segundo a crítica situacionista, o problema da alienação na sociedade do espetáculo é agravado pelo planejamento urbano, que representa o controle do espaço pelo capital. Em oposição ao urbanismo moderno funcionalista e segregador, os situacionistas formulam o urbanismo unitário, a 'construção integral de um ambiente em ligação dinâmica com experiências de comportamento'. A estrutura dinâmica do espaço, em detrimento à perspectiva estática da cidade cartesiana, é uma estrutura labiríntica, que propiciaria, por sua vez, a vivência urbana apaixonante. O urbanismo unitário enquanto estrutura transformável, conforme os modos de vida da sociedade, liga-se ao conceito de labirinto unitário, que ao contrário da ideia clássica de labirinto, não possui nem centro, nem periferia, nem nenhuma regularidade, é constituído por vários centros em movimento, é propício à atividade lúdica, pois liga-se às ideias de jogo, aventura e exploração. A ideia de jogo presente no conceito de labirinto unitário não se limita ao elemento de competição que vê como objetivo único encontrar as saídas, relaciona-se, sobretudo, com o sentido positivo de encontrar caminhos desconhecidos. O conceito unitário também está presente na poética do espaço de 
Hélio Oiticica que utiliza o labirinto como estrutura apropriada para elevar o 'espectador' à uma participação estética, como 'arquitetura transformadora de comportamento para práticas descondicionadas', ideal para a fruição do Crelazer. A partir da experimentação estética no labirinto Hélio aproxima a arte e a vida. Além disso, seus Penetráveis estão diretamente relacionadas ao comportamento labiríntico de sua deambulação urbana, empreendida como parte de seu processo criativo e incorporada posteriormente em seu Programa Ambiental com delirium ambulatorium. O delirium ambulatorium propõe experiências improvisadas de caminhar pela cidade, buscando chamar a atenção para a importância de se redescobrir o próprio espaço da cidade, numa atitude de 'poetizar o espaço', aproximando-se, sobremaneira, da deriva situacionista. Seus Penetráveis são uma resposta à sua deambulação urbana, podem ser compreendidos como 'mapas' psicogeográficos, uma vez que são uma resposta à cidade formal a partir da apreensão subjetiva dos espaços reais da cidade. Eles materializam ainda a estrutura labiríntica como expressão de seu ideal urbano, dinâmico, transformável e lúdico, aspiração da ideia de mundo que se cria no lazer, em oposição a categoria 'capitalismo-opressiva'. No desenvolvimento destas formulações destacam-se as experiência que Hélio vivenciou no Rio de Janeiro junto à favela da Mangueira, responsável pelo seu próprio descondicionamento social, bem como, seu 'contato-vivência' junto ao grupo Exploding Galaxy337. O grupo Exploding Galaxy configurava-se como uma comunidade experimental, onde todos viviam na mesma casa, num comportamento de viver e explorar a arte como vida. O principal modus operandi do Exploding Galaxy advinha justamente deste comportamento, realizavam deambulações urbanas, onde saíam sozinhos ou em grupo examinando a cidade, recolhendo materiais descartados, encenando pequenas peças, investigando e ressignificando os objetos e os comportamentos sociais, e chamavam essas deambulações de explorações transmídias. Hélio não só estabeleceu um contato bastante próximo com os integrantes do Exploding, chegando a morar por um curto período no mesmo endereço, na Balls Pond Road, n. 99, como realizou explorações transmídias, colhendo detritos enquanto deambulava pelas ruas de Londres. Este

337 As informações sobre o Exploding Galaxy foram obtidas através do contato com Michael Chapman, ex integrante do grupo. A vitalidade das atividades realizadas pelo grupo ao mesmo tempo o pouco conhecimento de sua trajetória motivam a continuidade dessas investigações no Pós-Doutorado. 
intenso contato com a comunidade experimental do Exploding Galaxy foi fundamental para a formulação do Crelazer e do Barracão, uma comunidade do lazer, que Hélio definiu como a experiência da totalidade, uma vez que não dissocia obra e arte, a partir do caráter de "lugar-recinto-contexto-obra", ou "ambient-recin-total", expressão que Hélio utilizou também para definir o Exploding Galaxy. A influência do Exploding Galaxy na formulação do Crelazer e do Barracão está explícito no texto "A obra, seu caráter objetal, o comportamento" que Hélio escreveu em dezembro de 1968, para ser publicado no Jornal O Paiz ${ }^{338}$. Por fim, essa 'estrutura-comportamento' do Barracão, transformável conforme o comportamento das pessoas, vai ao encontro da concepção de labirinto unitário e representa a proposição que mais se aproximou das formulações situacionistas de um novo espaço para uma nova sociedade, exploradas por Constant no projeto da Nova Babilônia.

338 Oiticica, Hélio. A obra, seu caráter objetal, o comportamento. [Londres], dezembro de 1968. in Catalogue Raisonné n. doc. 0160.68. 


\section{Referências Bibliográficas}

ABREU, Mauricio de A. Evolução Urbana do Rio de Janeiro: IPLANRIO (Instituto de Planejamento Municipal, Jorge Zahar Editor, 1988. $2^{\mathrm{a}}$ ed.

ANDRADE, Carlos Roberto Monteiro. À Deriva. Introdução aos Situacionistas. Óculum: PUC/Campinas, n. 4, 1993, p. 16-19; Prefácio dos livros "A Arquitetura e o Urbanismo Revisitados pela Internacional Situacionista", de Vanessa Grossman e "Apologia da Deriva", de Paola Berenstein Jacques.

ANDRADE, Carlos Roberto Monteiro. Ferrovias, nômades e exilados. in Revista Risco (revista de pesquisa em arquitetura e urbanismo, IAU USP), ano $1, \mathrm{n}^{\circ} 1,2^{\circ}$ semestre de 2003. p.17-22.

AMARAL, A. Arte e meio artístico (1961-1981): entre a feijoada e o x-burguer. São Paulo: Nobel, 1983.

Arte, para quê? A preocupação social na arte brasileira (19301970). Tese destinada ao concurso de livre docência na FAUUSP, 1983.

ANDREOTTI, Líbero e COSTA, Xavie (organizadores). Situacionistas: arte, política, urbanismo. Barcelona: Museu d'Art Contemporani de Barcelona, ACTAR Barcelona, 1996.

ANDREOTTI, Líbero. Pratique lidiche dell'urbanística situazionista. Lótus, Milão, $\mathrm{n}^{\circ}$ 108, p. 40-63, março de 2001.

AUGÉ, M. Não-lugares. Introdução a uma antropologia da super-modernidade. Campinas: Papirus, 1994.

ARAGON, L. Le Paysan de Paris. Paris: Gallimard, 1926.

ARANTES, O. B. F.; ARANTES, P. E. Um ponto cego no projeto moderno de Jurgen Habermas: arquitetura e dimensão estética depois das vanguardas. São Paulo: Brasiliense, 1992.

O lugar da arquitetura depois dos modernos. São Paulo:

Nobel/Edusp, 1993.

ARANTES, O B. F., VAINER, C., MARICATO, E. A cidade do pensamento único: desmanchando consensos. Rio de Janeiro: Vozes, 2000.

. Urbanismo em fim de linha. São Paulo: EDUSP, 2001. 
ARGAN, G. C. História da arte como história da cidade. São Paulo: Martins Fontes, 1989.

ARCHITECTURES fantastiques. L'Architecture d'Aujourd'Hui, Bologne (Seine), n. 102, juin-juillet 1962.

ATKINS, G. Asger Jorn. London: Metheuen, 1964.

AA.VV. Internazionale Situazionista 1958-1969. (Prefacio de Mario Lippolis). Torino: Nautilus, 1994.

BACHELARD, G. A poética do espaço. Tradução Antonio de Padua Danesi; Revisão da tradução Rosemary Costhek Abílio. São Paulo: Martins Fontes, 1988.

BANHAM, R. Megastructure: urban futures of the recent past. London: Thames and Hudson, 1976.

BASUALDO, C. (organizador). Tropicália: uma revolução na cultura brasileira (19671972). São Paulo: Cosac \& Naify, 2007.

BAUDALAIRE, C. Les fleurs du Mal. Paris: Librairie Générale Française, 1972.

BAUMAN, Zygmunt. Vida para o consumo. A transformação das pessoas em mercadoria. Tradução: Carlos Alberto Medeiros. Rio de Janeiro: Jorge Zahar Ed., 2008.

BAUMAN, Zygmunt. O mal-estar da pós-modernidade. Tardução Mauro Gama, Cláudia Martinelli Gama; revisão técnica Luís Carlos Fridman. Rio de Janeiro: Jorge Zahar Ed., 1998.

BEAUNE, Jean-Claude. Le vgabond et la machine: essai sur l'automatisme ambulatoire médicine, technique et société en France 1880-1910. Paris: Champ Vallon, 1983.

BEGUIN, F. As maquinarias inglesas do conforto. Espaço \& Debates, São Paulo, n ${ }^{\circ}$ 34: 39-54, 1991.

BENJAMIN, W. Charles Baudelaire um lírico no auge do capitalismo. Obras Escolhidas III. Tradução. José Carlos Martins Barbosa e Hemerson Alves Baptista. São Paulo: Brasiliense, 1989.

BENJAMIN, W. Rua de mão única. Obras Escolhidas II. São Paulo: Brasiliense, 1995. BERMAN, M. Tudo que é sólido desmancha no ar. A aventura da modernidade. Tradução Carlos Felipe Moisés, Ana Maria Loriatti. São Paulo: Companhia das Letras, 1986.

BERTELLI, P. Fotografia Situazionista. Nápoles: Edizioni la Città del Sole, 2005. 
BIVAR, Antonio. Verdes vales do fim do mundo.Rio Grande do Sul: L\&PM, 1985.

BOLLE, Willi. Fisiognomia da metrópole moderna: representação da história em Walter Benjamin. São Paulo: Editora da Universidade de São Paulo, 2000.

BOLLE, Willi. Passagens. São Paulo: IMESP, 2006.

BRAGA, Paula. A trama da terra que treme: Multiplicidade em Hélio Oiticica. Tese de Doutorado. FFLCH - USP, 2007.

BRAGA, Paula. (organizadora) Fios Soltos: a arte de Hélio Oiticica. São Paulo: Perspectiva, 2008.

BRETON, A. Nadja. Paris: Gallimard, 1989.

BRETT, Guy. Exploding galaxies: the art of David Medalla. London: Kala Press, 1995.

BRESCIANI, Maria Stella. Londres e Paris no século XIX: o espetáculo da pobreza. São Paulo: Editora Brasiliense, $19927^{\circ}$ Ed. (1982).

BRESCIANI, M. S. Metrópolis: as faces do monstro urbano (as cidades do século XIX).

Revista Brasileira, São Paulo, no 8 e 9: 35-68, 1985.

BUFFET, G. P. Rencontres avec Picabia, Apollinaire, Cravan, Duchamp, Art, Calder. Paris: P. Belfond, 1977.

CANEVACCI, M. A cidade polifônica: ensaio sobre a antropologia da comunicação urbana. Tradução Cecília Prada. São Paulo: Studio Nobel, 1997, 2ª ed.

CARERI, Francesco. Walkscapes: el andar como prática estética. Barcelona: Gustavo Gili, 2002.

CARERI, Francesco. Constant: New Babylon, una città nomade. Roma: Texto \& Immagine, 2001.

CALVINO, Ítalo. As cidades invisíveis. São Paulo: Companhia das Letras, 1990.

COLQUHOUN, Alan. La Arquitectura Moderna. Una historia desapasionada. Barcelona: Gustavo Gili, 2005.

COOK, Peter. Archigram. Londom: Studio Vista, 1972.

CORBIN, Alain. O território do vazio: a praia e o imaginário ocidental. Tradução Paulo Neves. São Paulo: Companhia das Letras, 1989.

CRAWFORD, Jane. Gordon Matta-Clark uma comunidade utópica: o SoHo na década de 1970. in Gordon Matta-Clark Desfazer o Espaço. Catálogo de Exposição. Gabriela 
Rangel e Tatiana Cuevas (curadoria). Museu de Arte Moderna de São Paulo - MAM, 11 de fevereiro a 04 de abril de 2010.

CUEVAS, Tatiana. Desfazer o espaço. in Gordon Matta-Clark Desfazer o Espaço. Catálogo de Exposição. Gabriela Rangel e Tatiana Cuevas (curadoria). Museu de Arte Moderna de São Paulo - MAM, 11 de fevereiro a 04 de abril de 2010.

DEBORD, Guy-Ernest. La Société du Spectacle. Paris: Éditions Champ Libre, 1971.

DEBORD, Guy-Ernest. A Sociedade do Espetáculo. Tradução Estela dos Santos Abreu. Rio de Janeiro, 1997.

DEBORD, Guy-Ernest. Panegírico. São Paulo: Editora Conrad, 2002. (texto tardio, autobiográfico, original de 1989).

DEBRAY, R. “A propos du spétacle: Réponse à um jeune chercheur”. In: Le Débat 85. Paris: mai/ago. 1995.

DELEUZE, Gilles e GUATTARI, Félix. Mil Platôs. Capitalismo e Esquizofrenia. São Paulo: Editora 34, 1997.

DROWER, Jill. The Exploding Galaxy. The Third Text: critical perspectives on contemporary art and culture. London, v. 22, n. 2, p. 229-236, 2008.

DWEK, Zizette Lagnado. Hélio Oiticica: O Mapa do Programa Ambienta. Tese de doutoramento. São Paulo: Dep. de Filosofia, FFLCH-USP, 2003.

DUARTE, P. S. Anos 60_Transformações da arte no Brasil. Rio de Janeiro: Campos Gerais, 2002.

ECO, Umberto. Obra Aberta. São Paulo: Perspectiva, 1976.

FAVARETTO, Celso. A invenção de Hélio Oiticica. São Paulo: EDUSP/FAPESP, $20002^{\mathrm{a}}$ ed. (1992).

FIGUEIREDO, Luciano. (organizador). Cartas 1964-74 Hélio Oiticica/Lygia Clark. Rio de Janeiro: Editor UFRJ, 1996.

FIGUEIREDO, Luciano, PAPE, Lygia e SALOMÃO, Wally (organizadores). Aspiro ao Grande Labirinto. Seleção de Textos (1954-1969). Rio de Janeiro: Rocco, 1986.

FERRARA, L. D. Os significados urbanos. São Paulo: Editora da Universidade de São Paulo: Fapesp, 2000.

FERREIRA, G., BUENO, G. ASBURY, M., MACHADO, M. (organizadores) Arte \& Ensaios. Edição Especial/Special Issue: Correspondência Transnacional/ Transnacional Correspondence, Programa de Pós Graduação em Artes Visuais/ Escola de Belas Artes, UFRJ, 2007. 
FILHO, César Oiticica (organizador). Hélio Oiticica, o museu é o mundo. Rio de Janeiro: Beco do Azougue, 2011.

FIZ, S. M.; VELASCO, J. M. de. La arquitectura del siglo XX. Madrid: Alberto Corazon, 1974.

FOSTER, H. Recodificação: Arte, Espetáculo, Política cultural. São Paulo: Casa Editorial Paulista, 1996.

FRAMPTON, K. História crítica da arquitetura moderna. São Paulo: Martins Fontes, 2000.

GORELIK, A. Das vanguardas a Brasília: cultura urbana e arquitetura na América Latina. Tradução Maria Antonieta Pereira. Belo Horizonte: Editora UFMG, 2005.

GROSSMAN, V. A arquitetura e o urbanismo revisitados pela Internacional Situacionista. São Paulo: Annablume/FAPESP, 2006.

GULLAR, F. Vanguarda e subdesenvolvimento. Ensaios sobre arte. Rio de Janeiro: Civilização Brasileira, 1984.

HALBWACHS, M. A memória coletiva. São Paulo: Vértice/ Editora Revista dos Tribunais, 1990.

HALL, P. “Cidades do Amanhã”. São Paulo: Editora Perspectiva, 1995.

HARDMAN, F. F. Trem fantasma: a modernidade na selva. São Paulo: Brasiliense, 1988.

HASSEN, J. A. A temporalidade na cultura contemporânea. Cópia mimeografada, 1999.

HILLMAN, J. “Cidade e alma”. São Paulo: Studio Nobel, 1993.

HOLLEVOET, Christel. Déambulations de la flânerie et la dérive dans la ville à l'appréhension de l'espace urbain dans fluxus et l'art conceptual. in Revista Parachute, $\mathrm{n}^{\circ}$ 68, outubro, novembro e dezembro, Canadá, 1992.

HOME, Stewart. Assalto à cultura: utopia subversão guerrilha na (anti) arte do séc. XX. Tradução Cris Siqueira. São Paulo: Conrad, 2004.

HORKHEIMER, M. Dialética do esclarecimento: fragmentos filosóficos/ Max Horkheimer e Theodor W. Adorno. Trad. Guido Antonio de Almeida. Rio de Janeiro: Jorge Zahar, 1985.

HUIZINGA, J. Homo ludens: o jogo como elemento da cultura. Tradução João P. Monteiro. São Paulo: Perspectiva, 1971. (1938)

HUYSSEN, A. As sementes do tempo. São Paulo: Ática, 1997. 
. Espaço e imagem: teoria do pós-modernismo e outros ensaios. Rio de Janeiro: UFRJ, 1994.

- Pós-modernidade e sociedade de consumo. Novos Estudos CEBRAP. São Paulo, nº12, jun.1985. . Seduzidos pela memória. Rio de Janeiro: Aeroplano, 2000.

JACOBS, J. Morte e vida de grandes cidades. São Paulo: Martins Fontes, 1999. JACQUES, Paola Berenstein (organizadora). Apologia da Deriva: Escritos situacionistas sobre a cidade. Rio de Janeiro: Casa da Palavra, 2003.

JACQUES, Paola Berenstein. Estética da ginga: A arquitetura das favelas através da obra de Hélio Oiticica. Salvador: Casa da Palavra, 2003.

JAMESON, Frederic. Pós-Modernismo, a lógica cultural do capitalismo tardio. São Paulo: Ática, 1996.

Sobre a intervenção cultural. In: Crítica Marxista 18. Campinas:

Revan, 2004.

. “Transformações da imagem na pós-modernidade”. A virada cultural. Rio de Janeiro: Civilização Brasileira, 2006.

JAPPE, Anselm. Guy Debord. Petrópolis: Vozes, 1999.

JEUDY, Henry Pierre. Memórias do social. Tradução Márcia Cavalcanti. Rio de Janeiro: Forense, 1990.

JEUDY, Henry Pierre. Espelho das cidades. Rio de Janeiro: Casa da Palavra, 2005.

JEUDY, Henri Pierre e JAQUES, Paola Berenstein (organizadores). Corpos e cenários urbanos: Trritórios urbanos e políticas culturais. Salvador: EDUFBA; PPGAU/FAUFBA, 2006.

KEHL, Maria Rita. O espetáculo como meio de subjetivação. In: Kehl, M. R., Bucci, E. Videologias: ensaios sobre televisão. São Paulo: Boitempo, 2004.

KEHL, Maria Rita. Fetichismo. In: Kehl, M. R. e Bucci, E. Videologias: ensaios sobre televisão. São Paulo: Boitempo, 2004

KOPP, A. Quando o moderno não era estilo e sim uma causa. São Paulo: Nobel/Edusp, 1990.

KRAUSS, R. E. Caminhos da Escultura Moderna. Tradução Julio Fischer. São Paulo: Editora Martins Fontes, 2001.

LA CELA, Franco. Perdersi. L'uomo senza ambiente. Laterza, 2000

LEFEBVRE, Henri. Critique de la vie quotidienne. Paris: Grasset, 1947. 
A vida cotidiana no mundo moderno. Tradução Alcides João de Barros. São Paulo: Editora Ática, 1991.

A revolução urbana. Belo Horizonte: Editora: UFMG, 2001.

O direito à cidade. São Paulo: Centauro, 2001.

. La somme et le reste. Paris: Meridiens Klincksieck, 1989.

LUKÁCS, G. História e consciência da classe: estudos de dialética marxista, 2 edição.

Rio de Janeiro: Elfos, 1989.

LYNCH, K. A imagem da cidade. São Paulo: Martins Fontes, 1997.

MARCOLINI, Patrick. Le Mouvement Situationniste: une histoire intellectuelle. Paris: L'échamppée, 2012.

MARCUSE, H. O homem unidimensional. A ideologia da sociedade industrial. Rio de Janeiro, Zahar, $5^{\mathrm{a}}$ ed., 1979.

MARTÍN-BARBERO, J. Comunicación y cultura. Unas relaciones complejas. Telos, Madri, n. 19, 1989.

. De los medios a las mediaciones. Comunicación, cultura y hegemonia. México: Gustavo Gilli, 1987.

Nuevas tecnologias y esquizofrenia cultural. In: MARTÍN-BARBERO, J. Procesos de comunicación y matrices de cultura. Itinerario para entrar y salir de la razón dualista. México: Gustavo Gilli, 1987.

MARX, Karl. O capital: crítica da economia política. 3 ed. Trad. R. Barbosa e F. Kothe. São Paulo: Nova Cultura, 1988.

MAFFESOLI, M. Sobre o nomadismo: vagabundagens pós-modernas. Rio de Janeiro/São Paulo: Editora Record, 2001.

MERLEAU-PONTY, M. Textos estéticos. São Paulo: Abril Cultural (coleção Os Pensadores), 1975.

MUMFORD, Lewis. A cidade na história: suas origens, transformações e perspectivas. São Paulo: Martins Fontes, 1982.

NIEUWENHUYS, Constant. New Babylon: art et utopie: textes situationnistes. Paris: Cercle d'Art, 2006.

PALLAMIN, M. Vera. Cidade e cultura: esfera pública e transformação urbana. São Paulo: Estação Liberdade, 2002.

Arte urbana, São Paulo: região central (1945 -1998). Obras de caráter temporário e permanente. São Paulo: Annablume: FAPESP, 2000. 
PAQUOT, T. Demeure terrestre. Enquête vagabonde sur l'habiter. Paris: Éditions de l’Imprimeur. Paris, 2005.

PRADO, Gilberto. Breve Relato da Pós Graduação em Artes Visuais da ECA-USP. ARS (São Paulo) [online]. 2009, vol. 7, n. 13, pp. 88-101. ISSN 1678-5320. http://dx.doi.org/10.1590/s1678-532020090000100006.

PEDROSA, Mario. Arte ambiental arte Pós-MOderna, Hélio Oiticica. in: Dos murais de Portinari aos espaços de Brasília. São Paulo: Perspectiva, 1981.

PEIXOTO, Nelson. Brissac. Cenário em ruínas: a realidade imaginária contemporânea. São Paulo: Brasiliense, 1987.

PEIXOTO, Nelson Brissac. Cidade sem Janelas. Arte/Cidade, 1994.

PEIXOTO, Nelson Brissac. A Cidade e seus Fluxus. Arte/Cidade, 1995.

PERNIOLA, Mario. Appunti per una storia dell'urbanistica labirintica. Revista di Estetica. Ano XIII, Fascículo II, 1968. (231-251).

PERNIOLA, Mario. Internacional Situacionista: O movimento que profetizou a "Sociedade do Espetáculo". São Paulo: Annablume, 2009.

PERRY, Anderson. “Compreensão”. In: As origens da Pós-modernidade. Rio de Janeiro: Jorge Zahar Editor, 1999. Paisagens urbanas. São Paulo: Nobel, 1996.

RANGEL, Gabriela. Desfazer o Labirinto. in Gordon Matta-Clark Desfazer o Espaço. Catálogo de Exposição. Gabriela Rangel e Tatiana Cuevas (curadoria). Museu de Arte Moderna de São Paulo - MAM, 11 de fevereiro a 04 de abril de 2010.

RADKOWSKI, G. H. Anthropologie de l'habiter. Vers le nomadisme. Paris: PUF, 2002.

RIDENTI, M. Intelectuais, estudantes e artistas: Paris, 1968. In: REIS FILHO, D. A. (organizador) Intelectuais, história e política: séculos XIX e XX. Rio de Janeiro: 7 Letras, 2000.

ROCHE, Daniel. Humeurs vagabondes: de la circulation des hommes et de l'utilité des voyages. França: Edições Fayard, 2004.

ROLNIK, S., GUATTARI, Felix. Micropolítica: cartografias do desejo. Petrópolis: Editora Vozes, 1986.

ROSSEAU, Jean-Jacques. Os devaneios do caminhante solitário. (Tradução Julia da Rosa Simões) Porto Algre: L \& M, 2011. 
RYKWERT, Simon. Swinging City. A Cultura Geography of London 1950-1974. Ashgate, 2011.

RYKWERT, J. A sedução do lugar. A história e o futuro das cidades. São Paulo: Martins Fontes, 2004.

SALOMÃO, Waly. Hélio Oiticica: qual é o parangolé e outros escritos. Rio de Janeiro: Rocco, 2003.

SANTOS, Milton. O espaço do cidadão. São Paulo: Studio Nobel, 2002. . Pensando o espaço do homem. São Paulo: HUCITEC, 1986.

SARTRE, J. P. O existencialismo é um humanismo; A imaginação; Questão de método. Seleção de textos de José Américo Motta Pessanha. Tradução de Virílio Ferreira. São Paulo: Abril Cultural, 1978. (Coleção Os pensadores).

SCHELLE, Karl Gottlob. A Arte de Passear. São Paulo: Martins Fontes, 2001.

SEVCENKO, Nicolau. A corrida para o séc. XXI. No Loop da montanha-russa. São Paulo: Cia das letras, 2002.

STORR, Robert (curador/organizador). Mapping. Catálogo de Exposição, The Museum of Modern Art, New York, outubro a dezembro de 1994.

SUBIRATS, Eduardo. A cultura como espetáculo. São Paulo: Studio Nobel, 1989. Vanguarda, mídia, metrópoles. São Paulo: Studio Nobel, 1993.

VANEIGEM, Raoul. A arte de viver para as novas gerações. São Paulo: Conrad Editora do Brasil, 2002.

VELLOSO, Rita de Cássia Lucena. O cotidiano selvagem. Arquitetura na Internacional Situacionista. in: www.vitruvius.com.br - arquitextos n. 027, agosto de 2002.

VIRILIO, Paul. Espaço Crítico. Rio de Janeiro: Editora 34, 1993.

WIGLEY, Mark. Constant's New Babylon: the hiper architecture of desire. Rotterdam: 010, 1998.

WIGLEY, Mark. El gran juego del urbanismo: Constant y el paradigma de "Nueva Babilonia". Arquitectura Viva, Madrid, n. 88, p. 46-49, enero-febrero, 2003.

WOLLEN, Peter. Situationists and Architecture. in: New Left Review 8. London, mar/abril, 2001. p. 123-139.

ZUMTHOR, P. Escritura e Nomadismo: entrevistas e ensaios. Tradução Jerusa Pires Ferreira e Sônia Queiroz. São Paulo, Cotia: Ateliê Editorial, 2005. 


\section{Documentos Catalogue Raisoneé de Hélio Oiticica}

\section{Textos e Artigos de Hélio Oiticica}

doc. 0086.72 - Diretivas para Metaesquemas - Ralph Camargo. (Instruções para impressão do catálogo da exposição "Hélio Oiticica Metaesquemas" na Galeria Ralph Camargo, São Paulo, 30 de outubro de 1972) Nova Iorque, 12 de fevereiro de 1972.

doc. 0035.64 - Bases fundamentais para uma definição de Parangolé. Rio de Janeiro, novembro de 1964.

doc. 0101.77 - O Objeto na Arte Brasileira nos Anos 60. (texto sobre o objeto na arte brasileira, feito a pedido de Daisy Peccinini). Nova Iorque, 5 de dezembro de 1977.

doc. 0108.67 - Aparecimento do Suprasensorial. (Texto feito para palestra, que serviu como tema para o debate no Simpósio de Brasília, organizado por Frederico Morais em dezembro de 1967, sendo publicado pela Revista GAM, $\mathrm{n}^{\circ} 13$ em 1968). Rio de Janeiro, novembro a dezembro de 1967.

doc. 0160.68 - Oiticica, H. A obra, seu caráter objetal, o comportamento. (Texto de autoria de HO, encomendado por Dilmen Mariani, para ser publicado no jornal "O Paiz"). Rio de Janeiro, dezembro de 1968.

doc. 0305.69 - As possibilidades do Crelazer. (Textos de Hélio Oiticica). Paris, 10 de maio de 1969.

doc. 0452.69 - Barracão. (Texto de Hélio Oiticica). Londres, 19 de agosto de 1969. 
doc. 0110.66 - Esquema Geral da Nova Objetividade. (texto de HO publicado no Catálogo de Exposição Nova Objetividade Brasileira no MAM/RJ), Rio de Janeiro, 17 de dezembro de 1966.

doc. 0152.68 - O Objeto. (Texto de HO para publicação na Revista GAM nº 15, 1968). Rio de Janeiro, 1968.

doc. 0133.68 - Texto elaborado como contribuição para ao debate "Critério para o julgamento de obras de arte contemporâneas", realizado no MAM-Rio de Janeiro, 21 de Maio de 2968.

doc. 0057.79 - De Hélio Oiticica para Biscoitos Finos. (Texto para ser publicado na Revista Biscoitos Finos). Rio de Janeiro, 11 de novembro de 1979.

doc. 0020.62 - Testemunho. (Texto de HO sobre sua obra). Rio de Janeiro, 1962.

doc. 1861.62 - A transição da cor do quadro para o espaço e o sentido de construtividade. (Texto de HO publicado na Revista Habitat $n^{\circ} 70$ sobre Teoria da Arte). Rio de Janeiro, dezembro de 1962.

doc. 0014.59 - Texto sobre Arte/Metafísica. (Texto de HO transcrito de seu diário), dezembro de 1959.

doc. 0015.60 - Cor, Tempo e Estrutura. (Texto de HO publicado no Suplemento Dominical do Jornal do Brasil). Rio de Janeiro, 26 de novembro de 1960.

doc. 0271.71 - Anotações para serem traduzidas para o inglês. (Texto de HO). Nova Iorque, 1 de setembro de 1971.

doc. 0201.72 - Texto sobre Parangolé Síntese. (Texto de HO). Nova Iorque, 26 de dezembro de 1972. 
doc. 0289.70 - Subterrânea. (Texto de HO sobre sua obra). Rio de Janeiro, 4 de setembro de 1970 .

doc. 0278.71 - Texto de HO sobre a participação do espectador na obra. (TextoReflexão). Nova Iorque, 10 de junho de 1971.

doc. 0365.69 - Texto de Hélio Oiticica sobre Éden. (Local não atribuído, porém escrito em inglês), 1969.

doc. 0367.69 - Crelazer. (texto de HO sobre Crelazer/Artigo). Londres, 14 de janeiro de 1969.

doc. 0816.69 - Hélio Oiticica on the Discovery of Creleisure. (artigo na Revista Art an Artists sobre o Crelazer, obra de HO e Exposição na Whitechapel Gallery em Londres), Londres, abril de 1969.

doc. 0384.69 - Célula-Matriz do Barracão. (Texto de autoria de HO com referência ao comportamento/criação da Célula-Matriz do Barracão). Londres, 18 de setembro de 1969.

doc. 1664.69 - Barracão Idea. (Texto explicativo de HO sobre a obra Barracão). Londres, dezembro de 1969.

doc. 0289.70 - Subterrânea. (Texto de HO explicando o conceito de subterrânea para a publicação no Jornal Pasquim). Rio de Janeiro, 4 de setembro de 1970.

doc. 0265.71 - PN15: Project 3: Subterranean Tropicalia Projects. (Síntese do Projeto 3 - PN 15 Subterranean Tropicalia Project). Nova Iorque, dezembro de 1971.

doc. 0266.71 - Projects. (Texto de HO sobre Tropicália Subterranean Projects). Nova York, 15 de setembro de 1971. 
doc. 0272.71 - PN16: $4^{\circ}$ Projeto dos Subterranean Tropicália Projects. (Texto de HO para PN16). Nova Iorque, 4 de dezembro de 1971.

doc. 0413.71 - Sobre PN16. (Texto de HO sobre PN16). Nova Iorque, setembro de 1971.

doc. 0277.71 - PN14 MAP (Planta do Penetrável e tradução para o português de orientações para performance do PN14). Nova Iorque, 1 de janeiro de 1971.

doc. 0055.79 - Para Acrescentar ao Texto de Nanci. (HO) (Informações para acrescentar ao texto O Rio Passo a Passo). Rio de Janeiro, 3 de fevereiro de 1979.

doc. 0480.73 - Neyrótika. (texto de HO para Catálogo da Expo-Projeção - 73). Nova Iorque, 1 de abril de 1973.

doc. 0200.73 - Bodywise. (Texto para Jimi Hendrix transcrito do NTBK1/73 (páginas 42 e 43. Obs. Ver manuscrito para o inglês doc. $n^{0}$ 0211.73). Nova Iorque, 23 de novembro de 1973.

doc. 0203.73 - Para Bodywise. Seguindo-se o Excerto de Haroldo de Campos Hagoromo (último episódio) - Apontamentos. (Texto-Projeto de HO). Nova Iorque, 22 de junho de 1973.

doc. 0528.71 - Barnbilônia. (Texto-Projeto de HO transcrito do Caderno, Ficha ${ }^{\circ}$ 1738.70). Nova Iorque, 23 de janeiro de 1971.

doc. 0256.66 - Parangolé Social e Parangolé Poético. (Texto de HO sobre sua obra entregue a Harry Laus do Jornal do Brasil). Rio de Janeiro, 21 de agosto de 1966.

doc. 0106.67 - Parangolé Coletivo. (Texto sobre "Parangolé Coletivo"). Rio de Janeiro, 8 de julho de 1967. 
doc. 0247.66 - Texto de HO sobre manifestação ambiental e Parangolé. (sobre participação coletiva, através do Parangolé e sobre manifestação coletiva). (folha manuscrita). Rio de Janeiro, 14 de junho de 1966.

doc. 0182.59 - Texto de HO sobre Arte. (Diário de HO contendo textos sobre arte, sobre Núcleos, sobre Projeto Cães de Caça, entre outros). Rio de Janeiro, 1 de dezembro de 1959 a 11 de maio de 1964.

doc. 0128.68 - Texto de HO sobre sua obra. (Texto sobre Tropicália e Nova Objetividade). Rio de Janeiro, 4 de março de 1968.

doc. 0304.69 - Londocumento. (Texto de autoria de HO para a coluna de Nelson Motta no Jornal Última Hora, publicado em 11 de setembro de 1969). Londres, 27 de agosto de 1969.

doc. 0883.71 - Oiticica: Exposição? Eu não! (Artigo de autoria de HO publicado na coluna Geleia Geral de Torquato Neto no Jornal Última Hora tratando da posição de HO sobre exposições convencionais para seu trabalho). Rio de Janeiro, 1 de setembro de 1971.

doc. 0120.65 - A dança na minha experiência. (Texto de autoria de HO sobre a importância do samba na sua obra). Rio de Janeiro, 12 de novembro de 1965 a 10 de abril de 1966.

doc. 0381. 69 - Apocalipopótese. (texto de HO para palestra, sobre Apocalipopótese). Brighton, 9 de outubro de 1969.

doc. 0387.69 - Apocalipopótese. (texto de HO para publicação - Universidade de Sussex). Brighton, 22 a 29 de outubro de 1969.

doc. 0943.78 - Mitos Vadios. (Texto de autoria de HO publicado no Jornal Diário de São Paulo para o evento Mitos Vadios). São Paulo, 5 de novembro de 1978. 
doc. 0066.78 - Texto-release para minha participação em Mitos Vadios de Ivald Granato. Rio de Janeiro, 24 de outubro de 1978.

doc. 0396.71 - Heliotapes 1 e 2: Haroldo de Campos. (entrevista com Haroldo de Campos feita por HO para publicação). Nova Iorque, 27-28 de maio de 1971.

doc. 0380.72 - Experimentar o experimental. (texto de HO pra Jorge da Cunha Lima publicar no Domingo Ilustrado/Especial sobre a semana de 22). Nova Iorque, 22 de março de 1972.

\section{Entrevistas}

doc. 0944.78 - Um mito vadio. (Entrevista concedida a Jary Cardoso. Estiveram presentes também Luís Fernando Guimarães, que tinha sido do grupo Oficina e o músico e compositor Jards Macalé). Jornal Folhetim. São Paulo, domingo, 5 de novembro de 1978.

doc. 2555.79 - Ivan Cardoso Entrevista Hélio Oiticica. (Depoimento para o Filme HO de Ivan Cardoso). Rio de Janeiro, janeiro de 1979.

doc. 0867.70 - Hélio Oiticica, Uma Arte sem Medo. (Entrevista de HO com Gilse Campos no Jornal do Brasil sobre sua Obra, Crelazer, Barracão e Participação do Espectador). Rio de Janeiro, 29 de janeiro de 1970.

doc. 0024.61 - Hélio Oiticica. Projeto Cães de Caça e Pintura Nuclear. (Transcrição de entrevista sobre exposição no MAM/RJ em novembro de 1961). Rio de Janeiro, 1 de novembro de 1961.

doc. 0059. 80 - Entrevista com Hélio Oiticica (Entrevista de Heloisa Buarque de Hollanda com HO). Rio de Janeiro, 14 de fevereiro de 1980. 
doc. 0246.66 - Entrevista a Marisa Alves Lima (Entrevista de Marisa Alves Lima com HO para a Revista Cigarra, Cronologia). Rio de Janeiro, 20 de julho de 1966.

doc. 0576.61 - Neoconcretos falam de sua exposição. (Entrevista de HO no Jornal do Brasil sobre sua participação na exposição neoconcreta no Museu de Arte Moderna de São Paulo). Rio de Janeiro, 21 de abril de 1961.

doc. 721.67 - Hélio Oiticica: a Vanguarda deve jogar fora o esteticismo. (Entrevista de HO para Mário Barata no Jornal do Commercio sobre sua obra). Rio de Janeiro, 16 de julho de 1967.

doc. 0869.70 - Mangueira e Londres na rota, Hélio propõe uma arte afetiva. (Entrevista de HO a Norma Pereira Rêgo no Jornal Última Hora sobre sua obra, sua estadia em Londres e sua relação com a Mangueira). Rio de Janeiro, 31 de janeiro de 1970.

doc. 1881.69 - Oiticica talks to Guy Brett. (Entrevista de HO por Guy Brett publicada na Revista Studio International). Londres, 1 de março de 1969.

doc. 2023.60 - Teoria do Não-Objeto. (Catálogo editado pelo suplemento dominical do Jornal do Brasil em contribuição à II Exposição Neoconcreta no Palácio da Cultura, Rio de Janeiro).

doc. 0871.70 - Hélio Oiticica. (Entrevista de HO a Luis Antonio Pires no Jornal O Jovem sobre seu trabalho, sua estadia em Londres e EUA). Rio de Janeiro, 6 de março de 1970.

doc. 1003.79 - Hélio Oiticica. (Entrevista de HO para a Revista Southern California Art Magazine de Los Angeles sobre sua obra. Los Angeles, 1 de novembro de 1979.

doc. 1726. 79 - Texto de HO para a Revista Arte Hoje. (Respostas de HO para questionário proposto pela Revista Arte Hoje). Rio de Janeiro, 25 de setembro de 1979. 
doc. 1835.70 - Oiticica e Capinam. (Entrevista de HO e Capinam no Jornal O Pasquim com Martha Alencar, Paulo Francis, Sérgio Cabral, Nelson Motta e Flávio Rangel sobre assuntos diversos). Rio de Janeiro, 6 a 12 de agosto de 1970.

\section{Catálogo de Exposição}

doc. 2083.69 - Catálogo da Exposição na Whitechapel Gallery. (Catálogo da Exposição da Exposição na Whitechapel Gallery de Londres). Londres, 25 de fevereiro a 6 de abril de 1969.

doc. 2483.86 - O que faço é Música. (Catálogo da Exposição na Galeria São Paulo "O que faço é Música"). São Paulo, fevereiro a março de 1986.

doc. 0613.65 - "Metarmophosis, 1965: Glass Bólide by Hélio Oiticica". Artigo na Revista Signals Newsbulletins. Londres, vol. 1, n. 8. jun-jul, de 1965.

\section{Textos e Artigos de Terceiros Sobre HO}

doc. 1868.66 - Pedrosa, Mario. Opinião... Opinião... Opinião. Correio da Manhã, Rio de Janeiro, 11 de setembro de 1966.

doc. 2489.91 - Herkenhoff, Paulo. O que ele fazia era música. Jornal Letras e Artes. Rio de Janeiro, 31 de janeiro de 1991.

doc. 2485.89 - Favaretto, C. A música nos labirintos de Hélio Oiticica. Revista da USP, São Paulo, fevereiro de 1990.

doc. 2381.92 - Favaretto, Celso. Oiticica excêntrico. Revista Guia das Artes, São Paulo, dezembro de 1992. 
doc. 2408.92 - Lagnado, Lizette. Hélio Oiticica: o que há de música em você. Revista Qualis, São Paulo, agosto de 1992.

doc. 2587.04 - Coelho, Frederico. O. Hélio Oiticica um escritor em seu labirinto. (Artigo de Frederico Coelho para a Revista Sibila) novembro de 2004.

doc. 2516.94 - Justino, Maria. J. Parangolés: a Embriaguez Dionisíaca. (Artigo de Maria Jóse Justino para a Revista de Ciências Humanas da Universidade Federal do Paraná). Curitiba, dezembro de 1994.

doc. 2471/sd - Morais, F. Pequeno Roteiro das Invenções de Hélio Oiticica. (Cronologia de HO). Rio de Janeiro, sem data atribuída.

doc. 1004.79 - Morais, Frederico. Acontecimentos Poéticos-Urbanos de Hélio Oiticica. (Artigo de autoria de Frederico Morais no Jornal O Globo sobre evento no Caju Kleemania no Rio de Janeiro). Rio de Janeiro, 19 de dezembro de 1979.

doc. 0056.79 - Valadares, Nanci. O Rio Passo a Passo. (Texto de Nanci Valadares mencionando evento Projeto in Progress Caju). Rio de Janeiro, dezembro de 1979.

doc. 0578.61 - Gullar, Ferreira. Os "Penetráveis" de Oiticica. (Artigo de autoria de Ferreira Gullar no Jornal do Brasil sobre os Penetráveis de HO). Rio de Janeiro, 7 de dezembro de 1961.

doc. 1860.61 - Pedrosa, Mário. Os Projetos de Hélio Oiticica. (Artigo de autoria de Mário Pedrosa publicado no suplemento dominical do Jornal do Brasil sobre HO e sua obra). Rio de Janeiro, 25 de novembro de 1961.

doc. 2084.68 - Morais, Frederico. Apocalipopótese no Aterro: arte de vanguarda levada ao povo. (artigo de autoria de Frederico Morais publicado no Jornal Diário de Notícias sobre a manifestação Apocalipopótese no Aterro do Flamengo/RJ). Rio de Janeiro, 26 de julho de 1968. 
doc. 2566.92 - Campos, Haroldo de. O músico da matéria. (Texto de Haroldo de Campos para o Jornal Folha de São Paulo). São Paulo, 16 de fevereiro de 1992.

doc. 2277.71 - Campos, Haroldo de. Hagoromo (O manto de plumas - Peça Nõ). (Fragmento de Hagoromo - fragmento final - feita por Haroldo de Campos e dedicada a HO). Nova Iorque, 1 de maio de 1971.

doc. 1662.74 - Campos, Haroldo de. Parangol(h)elium. (Poema de Haroldo de Campo em homenagem a HO). São Paulo, 1 de janeiro de 1974.

doc. 2526.67 - Morais, Frederico. Objeto e Participação. (Fragmento de texto de Frederico Morais para a Revista GAM n 4) 1 de janeiro a 31 de março de 1967.

doc. 1018.78 - Motta, Nelson. Mitos e Vadios no Fantástico. (nota de autoria de Nelson Motta no Jornal O Globo sobre o evento Mitos Vadios em São Paulo). Rio de Janeiro, 12 de novembro de 1978.

doc. 0950.79 - Marinho, Celso. 60 artistas dão hoje sua versão dos Mitos, na rua. (Artigo publicado no Jornal Folha de São Paulo sobre o evento Mitos Vadios em S. Paulo). São Paulo, 12 de novembro de 1978.

doc. 0946 - Turci, Fátima. "Vadiagem". (artigo e entrevista no Jornal Última Hora sobre o evento Mitos Vadios em São Paulo). Rio de Janeiro, 11 - 12 de dezembro de 1978.

\section{Correspondências ativas}

doc. 0920.71 - Carta para Mario Pedrosa. Babylon, New York, 30 de julho de 1971

doc. 0901.71 - Carta para Augusto de Campos. Babylon, New York, 16 e17 de outubro de 1971. 
doc. 0851.71 - Carta para Mário Pedrosa. (Comentários sobre Éden e Rhodislãndia). Nova York, 31 de outubro de 1971.

doc. 1179.71 - Carta de Mary e Mário Pedrosa. (fala sobre o trabalho Éden de HO). Chile, Santiago, 2 de outubro de 1971.

doc. 1047.69 - Carta para Roberta Salgado. (Fala do artigo Crelazer, publicado na Revista GAM e sobre o que produziu para o Simpósio em Los Angeles (The Firs International Tactile Sculture Symposium - Long Beach, L.A.). Londres, 23 de junho de

1969.

doc. 0547.69 - Carta para Guy Brett. (Carta de HO para Guy Brett falando sobre o Barracão, sobre o trabalho de Lygia Clark e Lygia Pape). Califórnia, 11 de julho de 1969.

doc. 0749.70 - Carta para Lygia Clark. (HO fala do sucesso da sua obra "Experiência Barracão 2” na Exposição do MAMA/NY). Rio de Janeiro, 2 de agosto de 1970.

doc. 0855.71 - Carta para Lygia Pape. (comentários sobre o projeto Barracão, Rhodislândia e Barnbilândia). Nova York, 26 de outubro de 1971.

doc. 0922.69 - Carta para Jean Clay. (HO fala dos planos para a construção da Célula Barracão I). Londres, 20 de agosto de 1969.

doc. 0923.69 - Carta para Antonio Manuel. (HO fala da construção da Célula Barracão I e venda de obras). Londres, 21 de agosto de 1969.

doc. 0924.69 - Carta para Ângela Oiticica (HO relata problemas para enviar suas obras para o Brasil e fala dos planos para uma série de Barracão). Londres, 21 de agosto de 1969. 
doc. 0925.69 - Carta para Ivan Cardoso Filho. (HO fala de seus planos para experiência Barracão). Londres, 26 de agosto de 1969.

doc. 0929.69 - Carta para Ângela Oiticica. (HO fala dos projetos de seu filme e da construção de uma Célula-Barracão, na Universidade de Sussex). Londres, 15 de setembro de 1969.

doc. 0930.69 - Carta para Amílcar de Castro. (HO fala da maquete que fez das Células-Barracão, de sua Experiência-Cinema e de experiências com fotografias, que denominou de "Psychophotos". Londres, 18 de setembro de 1969.

doc. 0983.69 - Carta para Rubens Gerchman. (HO fala de trabalhos para a Revista ROBHO e de projetos como o Barracão e do seu filme). Brighton, 2 de novembro de 1969.

doc. 0987.69 - Carta para Ângela Oiticica. (HO fala de sua apresentação no College of Education e do início da construção das Células-Barracão). Brighton, 5 de novembro de 1969.

doc. 0988.69 - Carta para Marisa Alvez de Lima. (HO fala da experiência Barracão e de Trabalhos nesse período). Brighton, 9 de setembro de 1969.

doc. 0992.69 - Carta para Rubens Gerchman. (HO fala da montagem das grandes Células da experiência Barracão I e de outros trabalhos como os “Contos”). Brighton, 12 de novembro de 1969.

doc. 0999.69 - Carta para Ângela Oiticica. (HO envia foto de Parangolé utilizado com os alunos da Universidade de Sussex, fala da experiência Barracão 1 e de Conto). Brighton, 16 de dezembro de 1969.

doc. 0912.71 - Carta para Ivan Cardoso. (Comentários gerais sobre o filme Wall St., Projeto Subterrânea e Barnbilândia). Nova York, 24 de agosto de 1971. 
doc. 1062.73 - Carta para Aracy Amaral. (HO comunica a Aracy Amaral não ser possível concluir Neyrótika para a Expo-Projeção e propõe Übercocca em substituição). Nova York, 14 de junho de 1973.

doc. 1063.73 - Carta para Aracy Amaral. (HO comunica Aracy Amaral que Neyrótika não deverá ser chamado Audio-Visual e sim “Não-Narração”). Nova York, 16 de abril de 1973.

doc. 0904.71 - Carta para Luis Carlos Maciel. (HO comenta texto Barnbilândia e entrevista com Haroldo de Campos para a publicação no jornal a Flor do Mal). Nova York, 24 de setembro de 1971.

doc. 0908.71 - Carta para Ângela Oiticica. (HO comenta projeto para ser executado na Praça da República em São Paulo com Ralph Camargo). New York, 6 de setembro de 1971.

doc. 0848.71 - Carta para Ivan Cardoso. (HO comenta Rhodislândia, livro-projeto e faz comentários gerais sobre parangolé e bólide caixa cara-de-cavalo). Nova Iorque, 12 de novembro de 1971.

doc. 1089. 71 - Carta para Ângela Oiticica. (Carta de HO para Ângela Oiticica sobre ambientação para o show de Gal Costa, na Boate Sucata; sobre a bolsa Guggenheim e vida em Nova Iorque). Nova Iorque, 11 de janeiro de 1971.

doc. 1092. 71 - Carta para César Oiticica. (Carta de HO para César Oiticica, sobre acordo de venda com Jean Boghici e comentando a vida em Nova Iorque). Nova Iorque, 6 de fevereiro de 1971.

doc. 1099. 71 - Carta para Caetano Veloso. (Carta de HO para Caetano Veloso sobre filmagem super 8, museu Guggenheim e comentários sobre vida em Nova Iorque). Nova Iorque, 4 a 8 de março de 1971. 
doc. 1101.71 - Carta para Waly Salomão. (Carta de HO para Waly Salomão sobre filmagem em Super 8, Projeto Babylonests, projeto Brasil Jorge e vida em Nova Iorque). Nova Iorque, 12 de março de 1971.

doc. 1105.71 - Carta para Waly Salomão. (Carta de HO para Waly Salomão sobre Projeto Barsil Jorge, Babylonests, filmagem em Super 8 e vida em Nova Iorque). Nova Iorque, 3 de abril de 1971.

doc. 0859.71 - Carta para Haroldo de Campos. (Descrição do cenário para o show de Gilberto Gil em Nova Iorque). Nova Iorque, 19 de outubro de 1971.

doc. 1151.71 - Carta para José Carlos Capinam. (Carta de HO para Capinam sobre Projeto Central Park). Nova Iorque, 25 de junho de 1971.

doc. 1152.71 - Carta para Luciano Figueiredo. (Carta de HO para Luciano Figueiredo sobre Projeto Central Park). Nova Iorque, 25 de junho de 1971.

doc. 1146.71 - Carta para Geraldo Sievers (Gerald Thomas). (Carta de HO para Geraldo Sievers sobre Projeto Central Park). Nova Iorque, 8 de junho de 1971.

doc. 1117.71 - Carta para Ivan Cardoso. (Carta de HO para Ivan Cardoso sobre projeto Brasil Jorge e considerações sobre vários assuntos). Nova Iorque, 11 de maio de 1971.

doc. 1118.71 - Carta para Lygia Clark. (Carta de HO para Lygia Clark sobre Projeto Central Park, Projeto Brasil Jorge, mercado, arte e cinema). Nova Iorque, 14 de maio de 1971.

doc. 0914.71 - Carta para Rogério Duarte. (HO fala de maquete para o projeto do Central Park). Nova Iorque, 13 de agosto de 1971.

doc. 0961.71 - Carta para Vera Pedrosa. (Menciona projeto Central Park e entrevista com Mário Montez para publicação no suplemento plug do jornal correio da manhã). Nova Iorque, 24 de julho de 1971. 
doc. 1049.69 - Carta para Lygia Pape. (Informa que está propondo ao Jewish Muse de N. Y. fazer uma exposição que se estenda pelo Central Park; fala de matéria publicada na revista cadernos brasileiros e da sua participação no simpósio de Los Angeles.

doc. 1119.71 - Carta para Waly Salomão. (Carta de HO para Waly Salomão sobre projeto Central Park). Nova Iorque, 21 de maio de 1971.

doc. 1141.71 - Carta para Carlos Vergara. (Sobre projeto Central Park e sobre entrevista para o suplemento do Correio da Manhã Jornal Plug). Nova Iorque, 27 de maio de 1971.

doc. 0966.71 - Carta para Luiz Otávio Pimentel. (HO discute conceitos relativos ao que ele chama experiências parangolé). Nova Iorque, 5 de julho de 1971.

doc. 1298.72 - Carta para Haroldo de Campos. (sobre o projeto E PET C LO). Nova Iorque, 25 de outubro de 1972.

doc. 1297.72 - Carta para Walter Zanini. (sobre o projeto E PET C LO e sobre evento capa Parangolé feita no corpo (PAMPLONA). Nova Iorque, 25 de outubro de 1972.

doc. 1296.72 - Carta para Luis Fernando Guimarães. (sobre Parangolé capa feita no corpo (PAMPLONA), sobre projeto No Rason To Get Excited e sobre transação com Ralph Camargo). Nov Iorque, 12 de outubro de 1972.

doc. 1294.72 - Carta para Luis Fernando Guimarães. (sobre venda de Metaesquemas, sobre realização de PN 16 NADA e sobre projeto No Reason to Get Excited). Nova Iorque, 30 de setembro de 1972.

doc. 1292.72 - Carta para Luciano Figueiredo. (sobre realização de PN16 NADA em São Paulo, sobre venda de metaesquemas e sobre Agripina Roma-Manhattan). Nova Ioque, 19 de setembro de 1972. 
doc. 1324.72 - Carta para Antônio Manuel. (sobre realização do Parangolé P33 Capa 26 e sobre texto parangolé-síntese). Nova Iorque, 28 de novembro de 1972.

doc. 1179.71 - Carta de Mário Pedrosa à Hélio Oiticica. (fala sobre trabalho de HO Éden). Nova Iorque, 2 de outubro de 1971.

doc. 0749.70 - Carta para Lygia Clark. (HO fala do sucesso da sua obra "Experiência Barracão 2" na Exposição do MOMA/NY). Nova Iorque, 2 de agosto de 1970.

doc. 0662.70 - Carta para Lygia Clark. (Comentários sobre Orgramurbana, Parangolés e realização de Capa do livro "Me segura que eu vou ter um troço" de Waly Salomão). Rio de Janeiro, 19 de outubro de 1970.

doc. 0549.69 - Carta para Lygia Pape. (Carta de HO para Lygia Pape relatando contatos com a direção da Galeria Whitechapel). Londres, 14 de janeiro de 1969.

doc. 0556.69 - Carta para Rubens Gerchaman. (HO fala de Whitechapel, relata sua experiência em Exploding Galaxy e opina sobre obras de Rubens Gerchaman e de Amílcar de Castro). Londres, 27 de janeiro de 1969.

doc. 1042.69 - Carta para Izo Neves de Barros. (HO relata exposição em Whitechapel). Londres, 29 de março de 1969.

doc. 1085.68 - Carta para Caetano Veloso. (Carta de HO para Caetano Veloso sobre futura exposição na Whitechapel Gallery, sobre Parangolé P23 Capa 19 Caetelesvelásia e sobre vida em Londres). Londres, 26 de dezembro de 1968.

doc. 1038.68 - Carta para Rubens Gerchman. (Carta de HO para Rubens Gerchaman sobre venda de obras para Ralph Camargo e viagem para Londres). Rio de Janeiro, 19 de novembro de 1968. 
doc. 1036.69 - Carta para Lygia Clark. (Carta de HO para Lygia Clark sobre futura exposição na Whitechapel Gallery, sobre tropicalismo no Brasil e considerações sobre arte). Rio de Janeiro, 8 de novembro de 1968.

doc. 1107.71 - Carta para Luis Fernando Guimarães. (Carta de HO para Luiz Fernando Guimarães sobre apresentação na Universidade de Rhode Island, apresentação na School of Visual Arts de Nova Iorque e considerações sobre cinema underground). Nova Iorque, 11 de abril de 1971.

doc. 1494.78 - Carta para Luis Fernando Guimarães. (Carta de HO para Luis Fernando Guimarães sobre matéria a ser publicada no suplemento folhetim, do jornal Folha de São Paulo). Rio de Janeiro, 22 de setembro de 1978.

doc. 1497.78 - Carta para Luis Fernando Guimarães. (Carta de HO para Luiz Fernando Guimarães sobre venda de Metaesquemas e sobre evento Mitos Vadios). Rio de Janeiro, 27 de outubro de 1978.

doc. 1498. 78 - Carta para Luis Fernando Guimarães. (Carta de HO para Luis Fernando Guimarães sobre evento Mitos Vadios e sobre matéria no Programa Fantástico da Rede Globo). Rio de Janeiro, 9 de novembro de 1978.

doc. 1493.78 - Carta para Ivald Granato. (Carta de HO para Ivald Granato sobre evento Mitos Vadios em São Paulo). Rio de Janeiro, 22 de setembro de 1978.

doc. 0994.69 - Carta para Nelson Motta. (HO fala de Subterrânea e de seus contos e autos). Brighton, 29 de novembro de 1969.

doc. 0826.69 - Carta para Lygia Clark. (HO fala de construção de obras para Whitechapel e de propostas para The First Tactile Sculpture Symposium em Los Angeles e para a Universidade de Sussex). Londres, 20 de junho de 1969. 
doc. 0688.69 - Carta para Amilcar de Castro. (carta em que HO complementa as informações enviadas na que ele denominou "carta conjunta Amílcar - Gerchman). Londres, 0688.69.

doc.0689.69 - Carta a Frederico Morais. (HO informa sobre as matérias jornalísticas acerca da Exposição na Galeria Whitechapel/Londres). Londres, 17 de março de 1969.

doc. 0542.69 - Carta a Rubens Gerchman. (Relatando suas experiências iniciais em Londres). Londres, 4 de janeiro de 1969.

doc. 1084.69 - Carta a Lygia Clark. (sobre vida em Londres, encontro com o Grupo Exploding Galaxy e sobre futura exposição na Whitechapel Gallery). Londres, 24 de dezembro de 1968.

doc. 0994.69 - Carta a Nelson Motta. (HO fala de Subterrânea e de seus contos e autos). Brighton, 29 de novembro de 1969.

doc. 0092.78 - Carta a Daniel Más. (Texto para a Revista Vogue). Rio de Janeiro, 8 de dezembro de 1978.

doc. 1495.78 - Carta a Olympio Vasconcelos. (sobre venda de obras por Esther Emílio Carlos, sobre matéria publicada no suplemento Folhetim do Jornal Folha de São Paulo e sobre projeto Parque Ecológico do Tietê). Rio de Janeiro, 30 de setembro de 1978.

\section{Estudos, Desenhos, Manuscritos e Anotações}

doc. 1737.67 - Caderno com estudos de Hélio Oiticica para Éden. Rio de Janeiro, 5 de outubro de 1967.

doc. 1917.67 - Relação de Materiais para Éden - Estudos. (Estudos para Éden com instrução). Rio de Janeiro, 4 de outubro de 1967. 
doc. 0180.74 - Desenho e anotações para ninhos na Christopher Street. (Bloco com desenhos e anotações para construção de ninhos no apartamento da Christopher Street). Nova York, 29 de novembro de 1974.

doc. 0521.78 - Planta de Ninho. (Desenho de planta para construção de ninho, tomando como referência a estrutura ninho studio CG, Carlos Góis). Rio de Janeiro, 30 de dezembro de 1978.

doc. 1779.69 - Anotações sobre Parangolé Capa feita no corpo e Barracão. Brighton, outubro a dezembro de 1969.

doc. 1833.72 - Subterranean Tropicalia. (publicação de plantas e anotações sobre Subterrânea Tropicália Projects na Revista Changes). Nova York, 15 de fevereiro de 1972.

doc. 1911.80 - Index Card - anotações para Esquenta pro Carnaval. (Anotações para o Acontecimento Poético-Urbano Esquenta pro Carnaval). Rio de Janeiro, 26 de janeiro de 1980.

doc. 0313.73 - Neyrótika. (Anotações de HO para Neyrótka). Nova Iorque, 1 de novembro de 1973.

\section{FOTOGRAFIAS E SLIDES}

doc. 2112.69 - Whitechapel - Visitantes - Ninhos, Penetráveis, Bólides. (São três fotografias P/B de visitantes participando da experiência Whitechapel, em Éden). Londres, 25 de fevereiro a 6 de

doc. 2116.69 - Whitechapel - B58 Bólide Ninho 1. (São três fotografias P/B de visitantes em Éden - B58 Bólide Ninho 1 - Whitechapel Gallery). Londres, 25 de fevereiro a 6 de abril de 1969. 
doc. 2117.69 - Whitechapel - Visitante em Penetrável PN1. (Fotografia P/B de visitante em Penetrável PN1 Éden, na Experiência Whitechapel). Londres, 25 de fevereiro a 6 de

doc. 2118.69 - Whitechapel -Bólide Cama (fotografia P/B de criança no B57 Bólide Cama (1968), em Éden, n a Experiência Whitechapel). Londres, 25 de fevereiro a 6 de abril de 1969.

doc. 2119.69 - Whitechapel -Éden (São três fotografias P/B de visitantes no B58 Bólide Ninho 1 (1967/9), Éden na Whitechapel Gallery). Londres, 25 de fevereiro a 6 de abril de 1969. 